
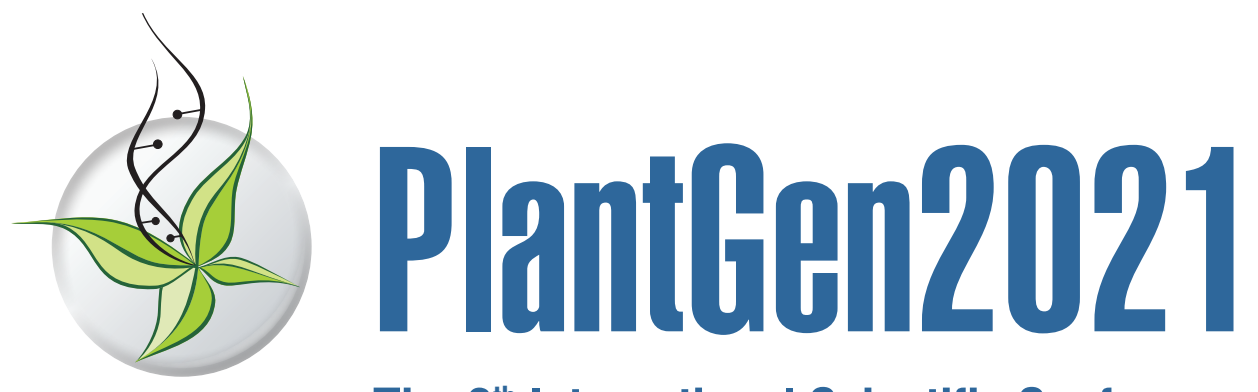

The $6^{\text {th }}$ International Scientific Conference

\title{
Plant Genetics,
} Genomics, Bioinformatics,

\section{and Biotechnology}

NOVOSIBIRSK, RUSSIA

JUNE 14-18, 2021 


\section{Organizers}

Institute of Cytology and Genetics, SB RAS (ICG SB RAS)

Kurchatov Genomic Center of ICG SB RAS (Grant No. 075-15-2019-1662)

Novosibirsk State University (NSU)

Ministry of Science and Higher Education of the Russian Federation

(Minobrnauki of Russia)

The Vavilov Society of Geneticists and Breeders (VSGB)

The Vavilov Society of Geneticists and Breeders (Novosibirsk Branch)

\section{Sponsors}

Gold

MARИM MAXMEDIKAL

PehOMika phenomika Llc

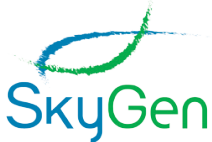

SKYGEN

Silver

QVADROS Bio QVADROS-BIO

helicon

$5 \sqrt{2}$

БиоГен-Аналитика

HELICON COMPANY

BIOGEN-ANALYTICA LLC

GenScript Biotech (Netherlands) B.V.

Bronze

\section{eppendorf \\ EPPENDORF}

weisstechnik

a schunk company
WEISS TECHNIK
MERCK LLC"MERCK"

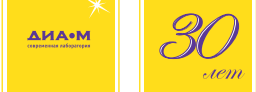

Dia-M LLC 
Institute of Cytology and Genetics, Siberian Branch of the Russian Academy of Sciences Novosibirsk State University

\section{PLANT GENETICS, GENOMICS, BIOINFORMATICS, AND BIOTECHNOLOGY (PlantGen2021)}

The $6^{\text {th }}$ International Scientific Conference

Abstracts

June 14-18, 2021

Novosibirsk, Russia

Editors:

Corr. Member of the RAS Alexey V. Kochetov

Professor, Dr. Sci. Elena A. Salina 
Plant Genetics, Genomics, Bioinformatics, and Biotechnology (PlantGen2021) : The $6^{\text {th }}$ International Scientific Conference (June 14-18, 2021, Novosibirsk, Russia); Abstracts / Eds. A.V. Kochetov, E.A. Salina. Institute of Cytology and Genetics, Siberian Branch of the Russian Academy of Sciences; - Novosibirsk: ICG SB RAS, 2021. - 261 p. - ISBN 978-5-91291-056-2. DOI 10.18699/PlantGen2021-000.

\section{International program committee}

Alexey Kochetov, Institute of Cytology and Genetics of SB RAS, Novosibirsk, Russia (Conference Chair) Elena Salina, Institute of Cytology and Genetics of SB RAS, Novosibirsk, Russia (Conference Co-Chair)

Olga Afanasenko, All-Russia Institute of Plant Protection, St. Petersburg, Russia

Dmitry Afonnikov, Institute of Cytology and Genetics of SB RAS, Novosibirsk, Russia

Andreas Börner, Leibniz Institute of Plant Genetics and Crop Plant Research (IPK), Gatersleben, Germany

Lyudmila Bespalova, National Center of Grain named after P.P. Lukyanenko, Krasnodar, Russia

Tatyana Gavrilenko, Federal Research Center the N.I. Vavilov All-Russia Institute of Plant Genetic Resources, St. Petersburg, Russia

Kirill Golokhvast, Siberian Federal Scientific Centre of Agro-BioTechnologies of the Russian Academy of Sciences (SFSCA RAS), Krasnoobsk, Russia

Nikolay Goncharov, Institute of Cytology and Genetics of SB RAS, Novosibirsk, Russia

Oxana Dobrovolskaya, Institute of Cytology and Genetics of SB RAS, Novosibirsk, Russia

Gennady Karlov, All-Russia Research Institute of Agricultural Biotechnology, Moscow, Russia

Rostislav Kovalevsky, Innovation center "Biruch-New Technologies", Alekseevka, Russia

Nikolay Kolchanov, Institute of Cytology and Genetics of SB RAS, Novosibirsk, Russia

Viktor Korzun, KWS SAAT SE \& Co. KGaA, Einbeck, Germany

Elena Kochieva, Federal Research Center Fundamentals of Biotechnology RAS, Moscow, Russia

Konstantin V. Krutovsky, Georg August University of Göttingen, Göttingen, Germany

Irina Mitrofanova, Kurchatov Genome Center - NBG-NRC, Yalta, Russia

Alexey Morgunov, FAO Technical Adviser, Riyadh, Saudi Arabia

Elena Potokina, St. Petersburg State Forest Technical University named after S.M. Kirov" (SPbSFU),

St. Petersburg, Russia

Igor Tikhonovich, All-Russia Research Institute for Agricultural Microbiology, St. Petersburg, Russia

Yerlan Turuspekov, Institute of Plant Biology and Biotechnology, Almaty, Kazakhstan

Elena Khlestkina, Federal Research Center the N.I. Vavilov All-Russia Institute of Plant Genetic Resources, St. Petersburg, Russia

Vladimir Shumny, Institute of Cytology and Genetics of SB RAS, Novosibirsk, Russia

\section{Local organizing committee}

Elena Salina, ICG SB RAS (Chairperson) Svetlana Zubova, ICG SB RAS (Co-chairperson)

Irina Leonova, ICG SB RAS

Svetlana Kalachikova, ICG SB RAS

Olga Petrovskaya, ICG SB RAS

Tatyana Karamysheva, ICG SB RAS

Alina Morkovina, ICG SB RAS

Erlan Tokpanov, ICG SB RAS

Larisa Eliseeva, ICG SB RAS

Andrey Kharkevich, ICG SB RAS

Tatyana Chalkova, ICG SB RAS

Lyudmila Kazantseva, ICG SB RAS

Vladimir Zamyatin, ICG SB RAS

Pavel Linkevich, ICG SB RAS

\section{Volunteers}

Alina Berezhnaya

Anastasia Kolozhvari

Diana Kuvaeva

Kirill Larichev

Zakhar Mustafin

Lilia Nesmelova

Mikhail Nesterov

Roman Perfil'ev

Anna Smirnova

\section{Contacts}

email: PlantGen2021@bionet.nsc.ru

https://conf.icgbio.ru/plantgen2021/ 


\title{
Institute of Cytology and Genetics, Siberian Branch of the Russian Academy of Sciences, Novosibirsk, Russia
}

\author{
Director: Corr. Member of the RAS Alexey V. Kochetov \\ Academic Advisor: Professor, Full Member of the RAS Nikolay A. Kolchanov \\ Academic Secretary: Candidate of Science (Biology) Galina V. Orlova \\ Phone: +7 (383) 3634985 ext. 1336, email: gorlova@bionet.nsc.ru
}

The Institute was founded in 1957, among the first institutions of the Siberian Branch of the Russian Academy of Sciences. It is situated in the Novosibirsk Akademgorodok. Presently, ICG SB RAS is an interdisciplinary biological center, which ranks among the leading biological institutions in Russia. The second step of the restructuring of the Federal Research Center Institute of Cytology and Genetics was completed in May 2017. Presently, ICG includes three affiliated branches:

- Siberian Research Institute of Plant Production and Breeding (SibRIPPB). The institute is located in Krasnoobsk Village and the Novosibirsk rural area. It conducts academic, prospective, and applied studies including the collection, examination, preservation, and utilization of plant genetic resources for obtaining new biological knowledge; expansion and improvement of crop gene pools;

- Research Institute of Clinical and Experimental Lymphology (RICEL);

- Research Institute of Internal and Preventive Medicine (RIIPM).

RICEL and RIIPM are situated in the Sovetskiy and Oktyabr'skiy districts of Novosibirsk. They conduct academic, prospective, and applied studies in molecular medicine and human genetics. They also provide medical care.

The branch «Kurchatov Genomic Center», ICG SB RAS became one of the divisions of the Federal Research Center.

Tasks of ICG SB RAS: Solution of top-priority problems in the development of the Russian science and technology sector in plant genetics and breeding, animal genetics and breeding, human genetics, biotechnology, and fundamental medicine by applying methods of molecular genetics, cell biology, and computational biology.

Strategic goal: Integrated studies in plant genetics and breeding, animal genetics and breeding, human genetics, fundamental medicine, and biotechnology by applying methods of molecular genetics, cell biology, and computational biology from the generation of academic knowledge to the solution of top priority problems set by Russian agricultural, biotechnological, biomedical, and pharmaceutical industries.

Staff: As on May 1, 2021, ICG included 119 scientific units, which employed 1483 members; of them 503 researchers, 2 RAS Advisors, 6 Full Members of the RAS, 4 Corresponding Members of the RAS, 96 Doctors of Science, and 307 Candidates of Science.

ICG trains 83 postgraduates and 26 ordinators.

Publications: The Institute ranks among acknowledged leaders in Russian biology. Numerous works of its researchers are published in Russian and foreign academic journals. In 2020 the overall number of publications in peer-reviewed periodicals is 725. In 2016-2020 the WoS system published 2068 articles from ICG researchers, and 37160 references to articles of the researchers were made within these five years.

Journals: Institute of Cytology and Genetics is the founder of the following journals: Vavilov Journal of Genetics and Breeding, Letters to Vavilov Journal of Genetics and Breeding, Atherosclerosis, Siberian Scientific Medical Journal, and Live Science.

Auxiliaries: Core facility "Center for Genetic Resources of Laboratory Animals", which includes the unique research unit "SPF vivarium", and seven shared access centers (www.bionet.nsc.ru/uslugi/).

The Federal Research Center Institute of Cytology and Genetics is looking to cooperate with scientific and commercial enterprises.

Address: Prospekt Lavrentyeva 10, Novosibirsk, 630090 Russia

phone: $+7(383) 363$ 4980; fax: $+7(383) 3331278$

URL: www.bionet.nsc.ru; email: icg-adm@bionet.nsc.ru 


\section{* NSU IN FACTS \& FIGURES}
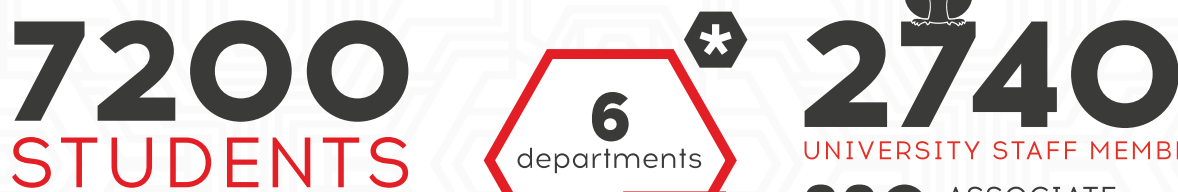

UNIVERSITY STAFF MEMBERS

$8 \mathbf{8 0}$ ASSOCIATE

570 FULL PROFESSORS

79 MEMBERS

1400

FOREIGN

STUDENTS

from 57 countries

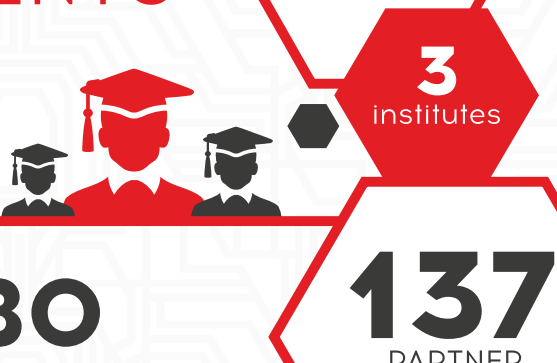

PARTNER UNIVERSITIES

REPRESENTED BY MOOCS STUDENTS

in 26 countries
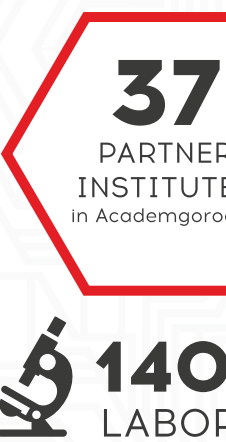

PARTNER

INSTITUTES

140

LABORATORIES

$7^{\text {th }}$ POSITION IN NATURAL QS University Rankings SCIENCES

TOP-100

QS University Rankings

TOP-100 in PETROLEUM os University Rankings ENGINEERING

TOP-150 In MATHEMATICS QS University Rankings

IN PHYSICS $H>20$
RESEARCH GROUPS ARE

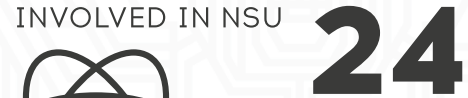

INTERNATIONAL COLLABORATIONS in the field of elementary particle physics and life sciences

\section{JOINT PROGRAMS} WITH COMPANIES:

Baker Huges, OSCiAl, Intel, Yandex, 2GIS, Academpark, Biotechnopark, Sberbank Technologies

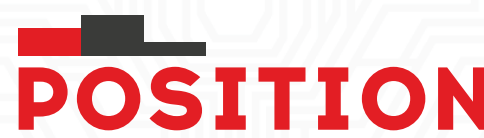
$5^{\text {th }}$

QS UNIVERSITY RANKINGS EMERGING EUROPE AND CENTRAL ASIA

\section{1-125 ${ }^{\text {th }}$ POSITION}

THE TIMES HIGHER EDUCATION WORLD REPUTATION RANKINGS

\section{TOP-250}

QS UNIVERSITY RANKINGS among 20000 world universities 


\section{Компания «Максим Медикал» - эксклюзивный дистрибьютор компаний LGC Biosearch Technologies и TwistDx Limited}

Меняющийся климат и рост населения бросают вызов мировому сельскому хозяйству. В этих условиях ученые обращаются к передовым инструментам геномики для решения своих задач. Независимо от того, над чем работает ваша команда, будь то повышение качества продуктов питания, обеспечение продовольственной безопасности или повышение производительности, сотрудничество с Biosearch Technologies предоставит Вам доступ к целому портфелю точных, надежных и высококачественных геномных инструментов, которые помогут решить научные задачи и преодолеть проблемы производительности, стоящих перед мировым сельским хозяйством.

Оборудование и реагенты для генотипирования и маркер-вспомогательной селекции растений и животных

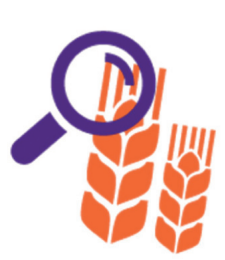

Allegro $^{\text {TM }}$ - кастомные наборы NGS от 100 до 10,000 маркеров для широкого спектра растений и животных;

$\boldsymbol{K A S P}^{\text {тм }}$ - экономичная и точная аллель-специфическая технология ПЦРгенотипирования для поиска и валидации селекционно-значимых маркеров, до 1000 SNP;

$\boldsymbol{R P A}$ - рекомбиназная полимеразная амплификация (RPA) является экспресс-альтернативой ПЦР, позволяет диагностировать фитопатогены/ГМО в течение 10-15 мин без специального оборудования;

BHQ - зонды Black Hole Quencher с улучшенными спектральными параметрами, обе-

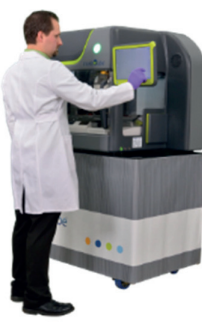
спечивающие производительность, необходимую для повышения эффективности ПЦР и качества данных из сельскохозяйственных образцов независимо от их качества;

$\mathbf{N x S e q}{ }^{\circledR}$-целевое обогащение и подготовка библиотек для NGS;

sbeadex SAB (sequencing application beads) - магнитные частицы для выделения нуклеиновых кислот и селекции фрагментов по размеру для подготовки NGS-библиотек; QuickExtract $^{\mathrm{Tm}}$, MasterPure ${ }^{\mathrm{Tm}}$ - наборы для быстрого выделения и очистки ДНК и РНК из растительного материала;

Расходные материалы для ПЦР: мастер-миксы KlearKall и EconoTaq ${ }^{\circledR}$, лабораторный пластик Sarstedt и Biofil.

Intelliqube - высокопроизводительный автоматизированный комплекс для генотипирования, включающий модуль жидкостного дозирования сборки ПЦР, амплификации и детекции. Вместо планшетов запаиваемая 768-луночная лента (Array Tape), что значительно экономит реагенты.

- Производительность до 24000 SNP / 8 часов

- Модуль детекции для широкого спектра красителей 480-620 нм (15 фильтров)

o Приложения: ПЦР по конечной точке, real-time ПЦР, мультиплекс, изотермическая ПЦР

Hydrocycler2 - высокопроизводительный термоциклер с водяной баней, емкость до 16 планшетов. Сочетание высокой пропускной способности, эффективности и надежной конструкции. Представляет собой альтернативу традиционным амплификаторам на основе элементов Пельтье.

- Использование воды для отвода тепла обеспечивает множество преимуществ, включая возможность параллельного термоциклирования для нескольких планшетов с минимальной разницой температур между ними.

- Продолжительность цикла на 40\% меньше, поскольку нет необходимости повышать или понижать температуру во время цикла ПЦР

о Планшеты автоматически перемещаются из одного резервуара в другой, температура в каждом из них точно контролируется

\section{Услуги генетического анализа}

ООО «Максим Медикал» авторизованный провайдер услуг генетического анализа LGC Genomics (Aнглия). Вам требуется лишь передать образцы нашим специалистам, мы возьмем на себя всю рутину пробоподготовки.

- Генотипирование «Все включено»: выделение ДНК, синтез праймеров, генотипирование, выдача результатов. В основе патентованные технологии SeqSNP ${ }^{\text {м }}$ и KASP ${ }^{\text {тм }}$. Масштаб проекта от 1 SNP до 10000 SNP

- $\quad$ SeqSNP - уникальная технология целевого NGS на анализаторах Illumina. Идеально для ускорения селекционных программ: масштаб от 100 до 100000 SNP

Сроки выполнения работ от 1.5 до 3 месяцев в зависимости от масштаба эксперимента и вводных данHых.

Наши контакты: www.maxmedikal.com

Дмитрий Чемерис dmitriy@maxmedikal.com +7925 7797657

Максим Патрин max@maxmedikal.com +79263861806 


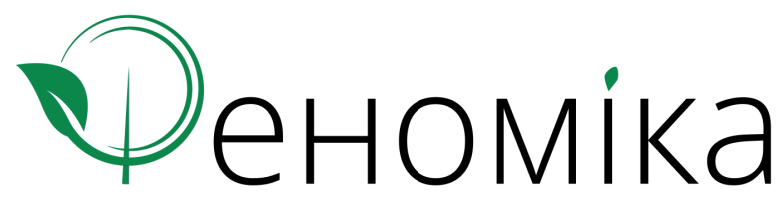

ООО «Феномика» - поставщик инновационных решений для фенотипирования растений и агробиотехнологий государственным и частным заказчикам.

Системы фенотипирования и гравиметрического анализа
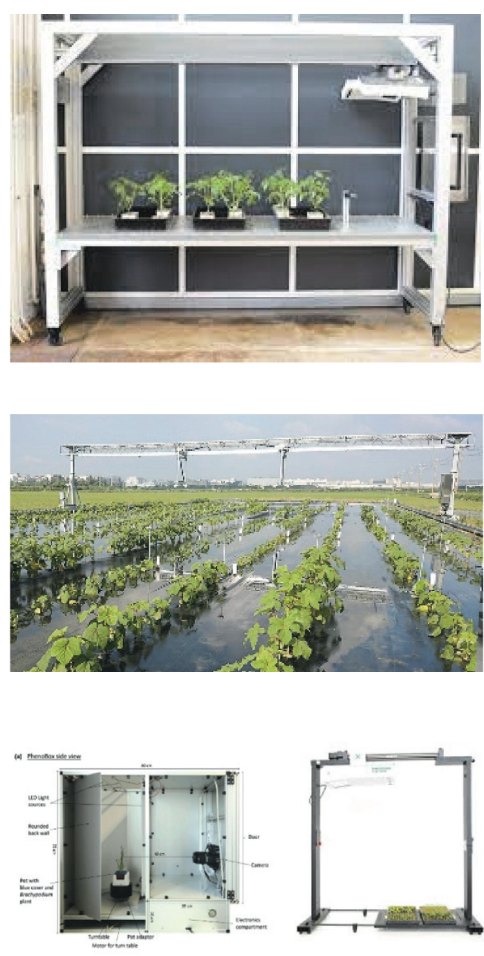

Компактные системы фенотипирования Microscan (Phenospex) и Phenobox (Vienna Scientific, Австрия) для одиночных растений или малого количества образцов. Высота растений от 10 см до $50 \mathrm{~cm}$.

Системные теплицы с встроенными модулями для фенотипирования и анализа транспирации растений DroughtSpotter

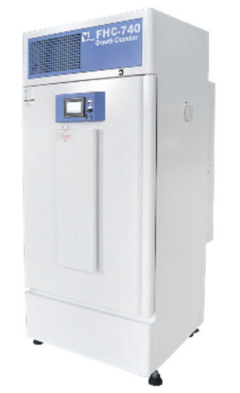

Камеры рост растений HiPoint (Тайвань)

- Объем камеры от 50 л до 3000 л

- Отдельные или встраиваемые камеры по Т3 заказчика

- Высокое качество сборки по доступной цене

- Опции: модуль регулировки СО2 и модуль регулировки влажности

- Широкий выбор систем подсветки и оснащение камерами машинного зрения

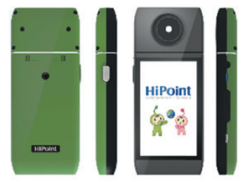

Спектрофотометр для растений HR-550 HiPoint. Наладонный измеритель ключевых оптических параметров окружающей среды (освещенность, ФАР, длина волны и мн. Другое)

Компоненты для интеграции:

-Камерымашинногозрения:УФ/видимогоспектра, ближнего ИК(NIR), гиперспектральные камеры, лидары, оптика, кабели. 
Компания SkyGen - крупный поставщик оборудования, реагентов и SkyGen расходных материалов для исследований в области life sciences, а также биотехнологических и фармакологических производств России и СНГ.

В настоящее время мы являемся эксклюзивным дистрибьютером продукции компаний New England Biolabs, Oxford Nanopore Technologies, 10x Genomics, Nimagen, Bio Molecular Systems и официальным дистрибьютером продукции компаний QIAGEN, BioSan, Agilent Technologies, Sigma-Aldrich и Thermo Fisher Scientific.

Для каждого клиента мы стремимся подбирать комплексное и оптимальное решение научной задачи: от дизайна эксперимента до интерпретации данных.

Важное значение компания SkyGen придает научной и сервисной поддержке своих покупателей. Наши квалифицированные специалисты помогут вам запустить сложное оборудование и реализовать нестандартные протоколы исследований. Воспользовавшись услугами нашей сервисной службы, вы сможете откалибровать и поверить ваши средства измерения, а также валидировать чистые помещения и широкий спектр приборов.

www.skygen.com

info@skygen.com

$8(800) 333-12-26$

Выделение нуклеиновых кислот из растительных образцов

Наборы для выделения НК от компании MicroGEM (ZyGEM) основаны на работе термофильных ферментов. Данный подход является более экологичным, простым и быстрым по сравнению с традиционными методами экстракции НК.

Основные преимущества наборов:

- нет потерь HK, что позволяет работать с малыми объемами образцов

• нет риска контаминации, выделение происходит в одной пробирке,

• выделение менее, чем за 20 минут, поскольку нет потребности в отмывках.
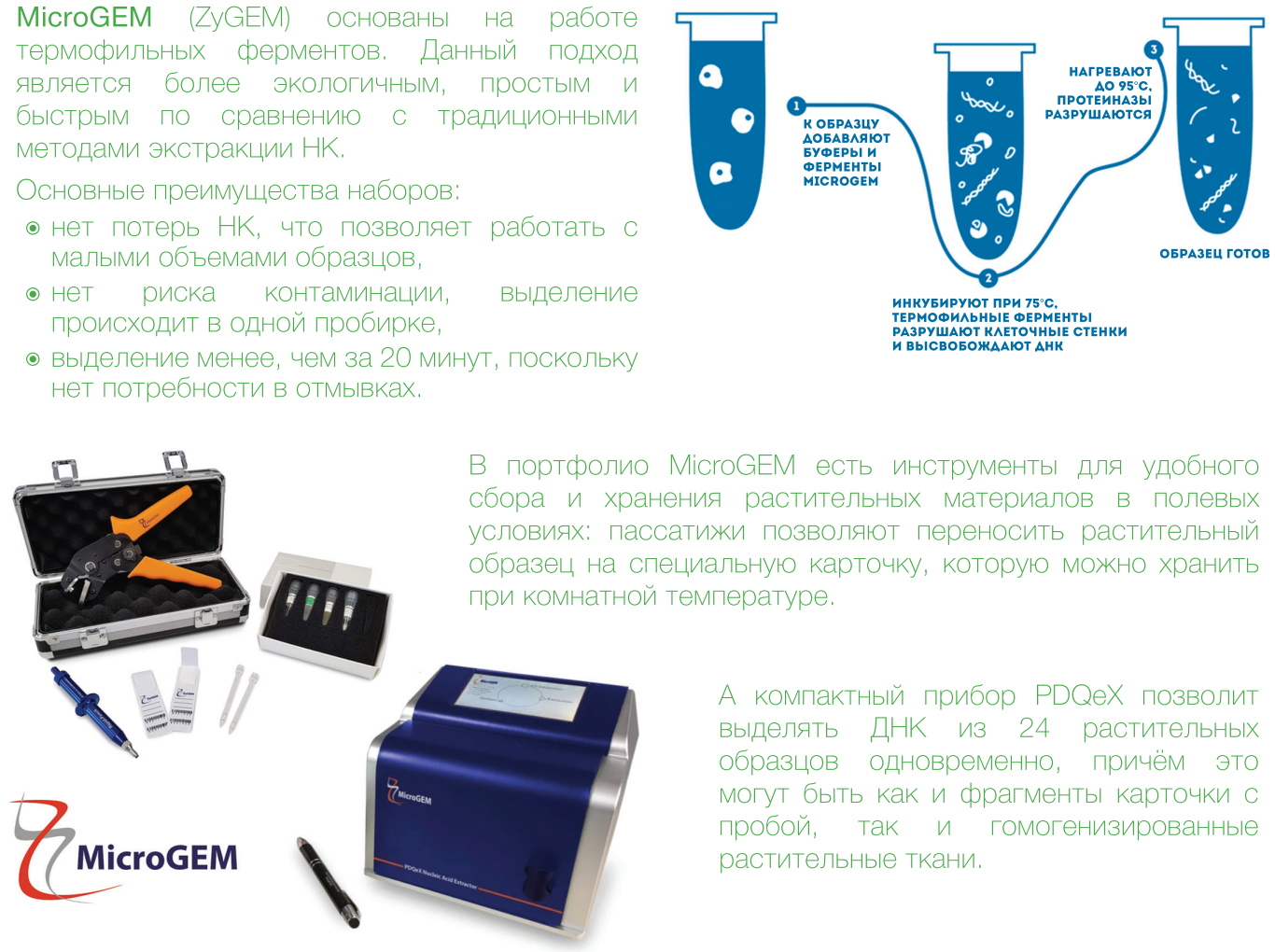

А компактный прибор PDQеX позволит выделять ДНК из 24 растительных образцов одновременно, причём это могут быть как и фррагменты карточки с пробой, так и гомогенизированные растительные ткани 
Секвенирование геномов растений крайне важно для сохранения видов и попыток усовершенствования различных полезных качеств, однако, сейчас секвенировано всего 250 растительных геномов, что очень мало по сравнению с этим же показателем для бактерий (160 000 геномов).

Почему же так мало растений отсеквенировано?

Геномы растений:

• имеют большую длину;

• имеют много повторяющихся элементов (например, в кукурузе около 80\% ДНК - повторы);

• полиплоидны (например, геном клубники представлен 56 хромосомами).

Эти особенности растительных геномов делают секвенирование слишком дорогим и трудоёмким методом, однако, есть современная технология секвенирования новейшего поколения, которая позволяет решить эту проблему.

Почему нанопоровое секвенирование от компании Oxford Nanopore Technologies идеальное решение для секвенирования растительных геномов:

• Длинные прочтения: нанопоровое секвенирование позволяет получить риды длиной до 2 Мб, что существенно упрощает сборку растительных геномов.

- Масштабируемость: можно использовать портативный MinlON в полевых условиях или высокопроизводительный PromethlON для получения большого количества данных.

- Простая и быстрая пробоподготовка: используя набор для быстрой пробоподготовки, можно начать секвенировать ваш образец уже через 10 минут.

- Прямая детекция: позволяет определить модифицированные основания без применения бисульфиидной конверсии.
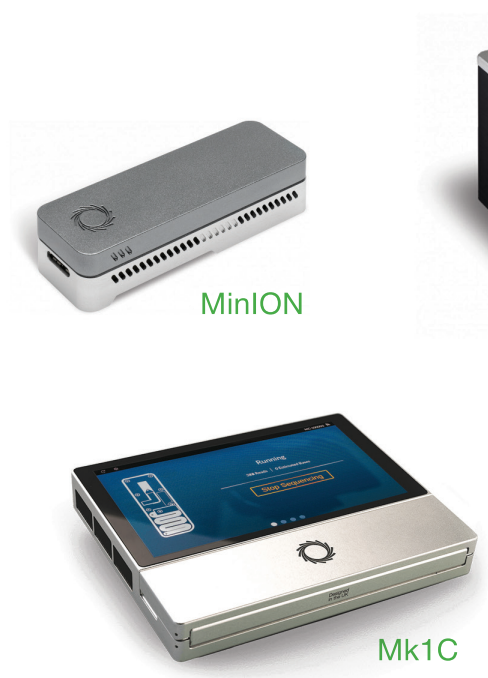

Узнать больше:$$
\text { 매잔. }
$$

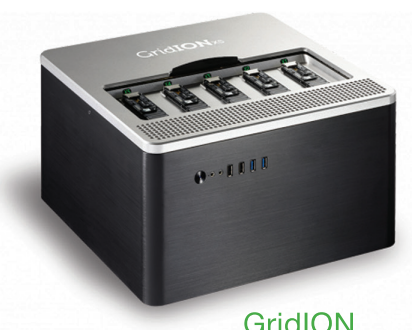

\section{GridION}
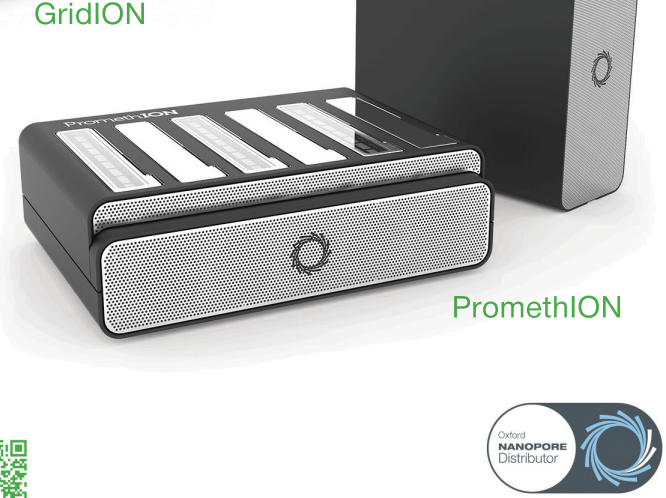

www.skygen.com 


\section{QVADROS Bio}

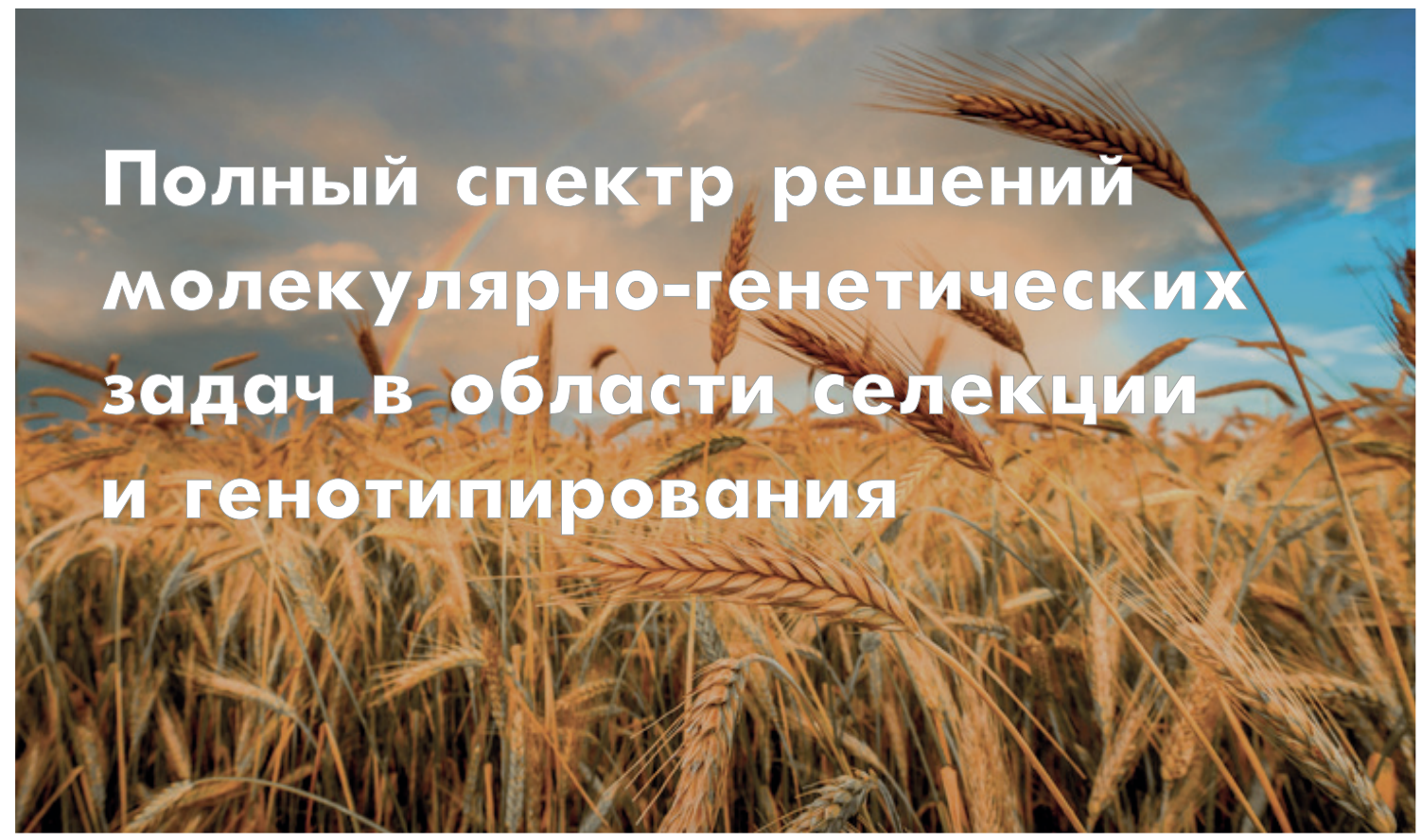

Анализ экспрессии генов растений

Секвенирование генома растений

Генотипирование растений

Генная инженерия
ThermoFisher S C I E N TIFIC

ГМО тестирование

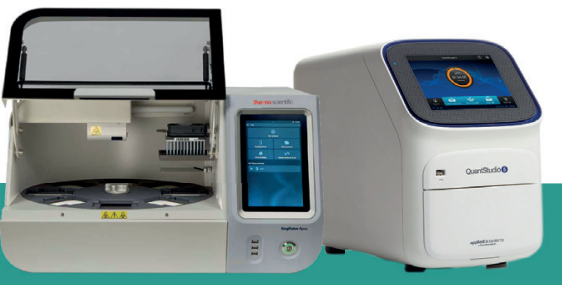

Амплификаторы QuantStudio 5 и системы экстракции нуклеиновых кислот KingFisher Арех для ПЦР

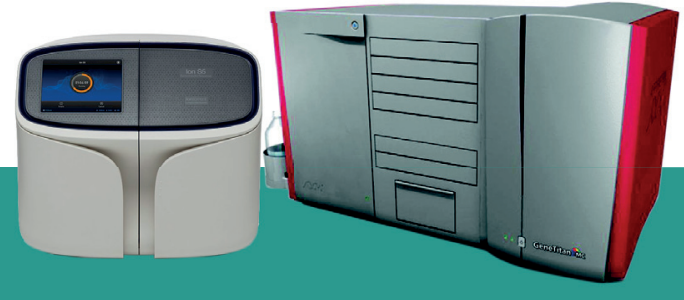

Системы IonGeneStudio 55 и GeneTitan для генетических исследований

www.qvadrosbio.ru • $8(495)$ 22-800-80 - info@qvadrosbio.ru QVADROS 


\section{ДЕЛАЕМ ВОЗМОЖНОЙ РАБОТУ ЛАБОРАТОРИЙ В РОССИИ НА МИРОВОМ УРОВНЕ}
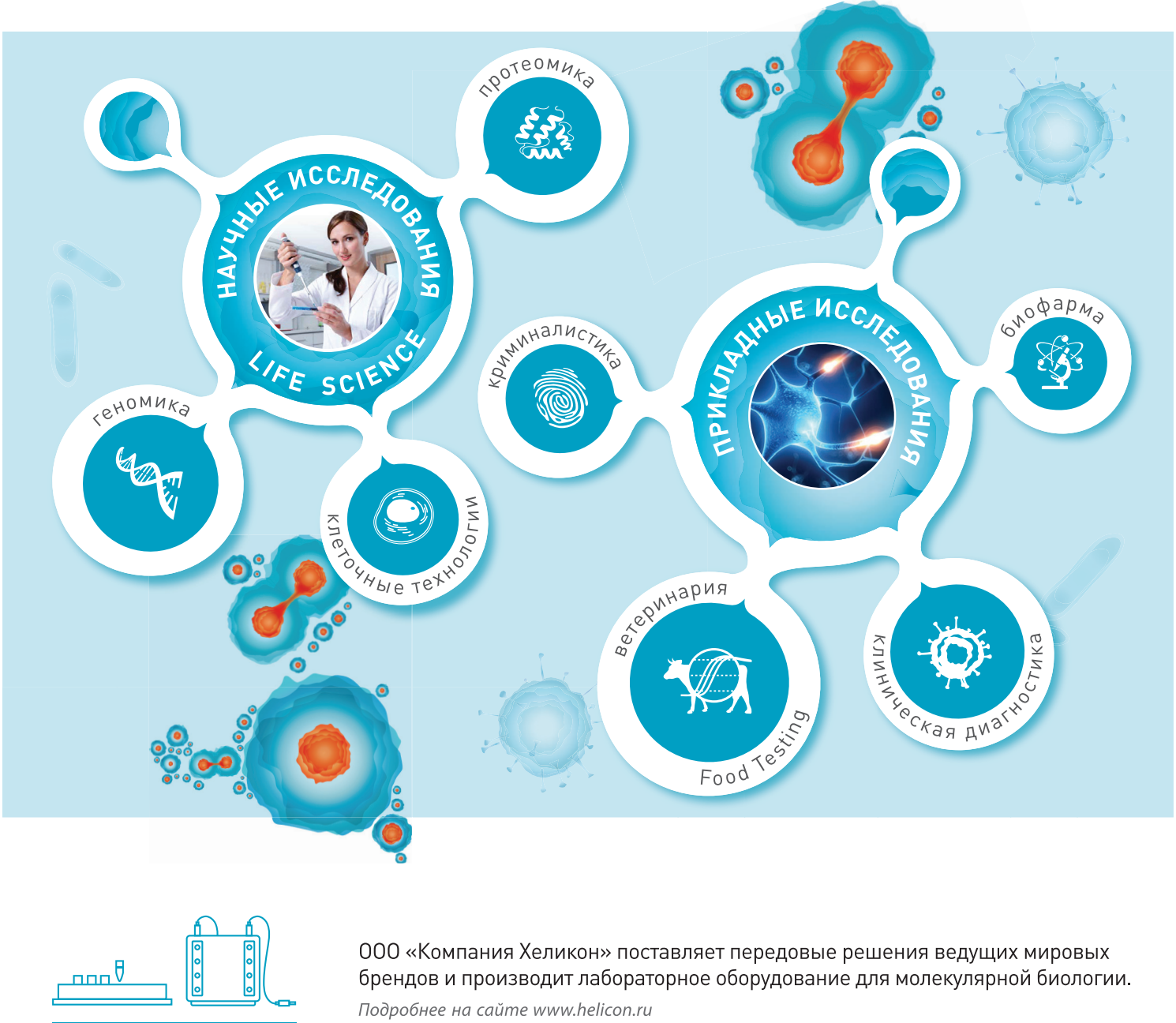

000 «Компания Хеликон» поставляет передовые решения ведущих мировых брендов и производит лабораторное оборудование для молекулярной биологии. Подробнее на сайте www.helicon.ru
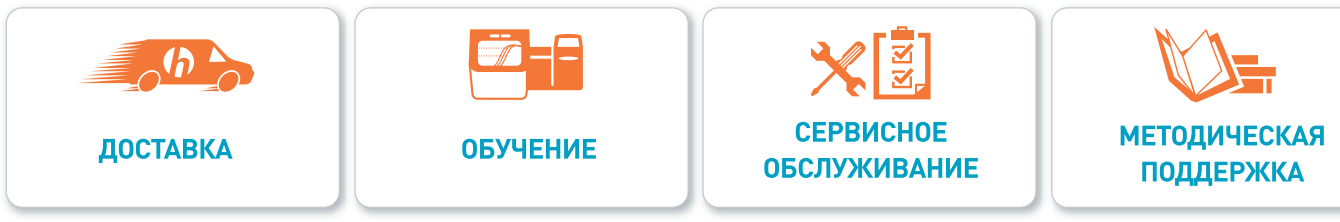

Центральный офис:

121374 г. Москва, Кутузовский проспект, д. 88 Тел. 8 (800) 770-71-21 Факс +7 (495) 930-00-84 mailahelicon.ru

www.helicon.ru
Представительство в Сибирском регионе: 630090 г. Новосибирск, ул. Инженерная, 28
Тел, +7 (383) 207-84-85, novosibirsklahelicon.ru

Представительство в Северо-Западном Регионе: Представительство в Северо-Западном Регионе:
195220 г. Санкт-Петербург, ул. Гжатская д. 22 корп. 1 Тел. +7 (812) 244-85-52, spbahelicon.ru
Представительство в Приволжском регионе: 420021 г. Казань, ул. Татарстан, д. 14/59, оф. 201 Тел. +7 (843) 202-33-37, volgaßahelicon.ru

Представительство в Южном регионе:

344116 г. Ростов-на-Дону, ул. 2-ая Володарская, д. 76/23а Тел, + 7 (863) 294-87-66, rostovahelicon.ru 
127422, Москва, ул. Тимирязевская, д. 1, стр. 2

Тел./факс: +7 4997046244

84997046244@bga.su

www.bga.su

Имея многолетний опыт в сфере поставки и сервисного обслуживания высокотехнологичного оборудования для биологии и медицины, наша компания БИОГЕН-АНАЛИТИКА (БГА) в своей работе считает приоритетным популяризацию и внедрение передовых технологий и инноваций в современную науку с целью решения самых различных задач, которые ставят перед собой российские ученые, специалисты в области медицины и работники высших учебных заведений в сфере биологии, медицины и нанотехнологий.

Основными приоритетами нашей компании БИОГЕН-АНАЛИТИКА являются индивидуальный подход к подбору способов решений задач наших коллег, друзей и партнеров посредством оборудования, которое мы представляем, и привнесение высоких технологий в российскую науку и медицину, что в конечном итоге улучшает показатели здоровья и качество жизни в нашей стране в целом.

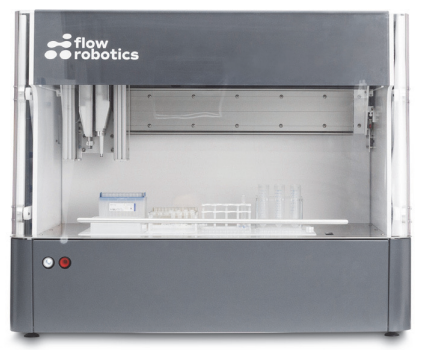

\section{Роботизированная система Flowbot Flow Robotics (Дания)}

В современной лаборатории огромное количество рутинных операций может выполнять роботизированная станция. Мы рады предложить новинку - систему flowbot ${ }^{\mathrm{TM}}$ ONE , которая полностью открыта для использования пластика (в том числе наконечники) любого производителя. Позволяет работать как с ДНК, так и белками, повышая производительность по сравнению с ручным выделением в несколько раз. Возможно оснащение блоком охлаждения, шейкером, а также сканером баркодов.

\section{ДНК-амплификаторы в реальном времени от Azure Azure Biosistems, (США)}

Предлагаем приборы для проведения Real time ПЦР от Azure для проведения точной и быстрой амплификации с последующей детекцией по трем или шести каналам. Быстрый нагрев - на 20\% быстрее большинства аналогов других производителей, точный и всегда воспроизводимый результат - это основные преимущества. Позволяет работать, как со встроенным компьютером, так и с внешним.
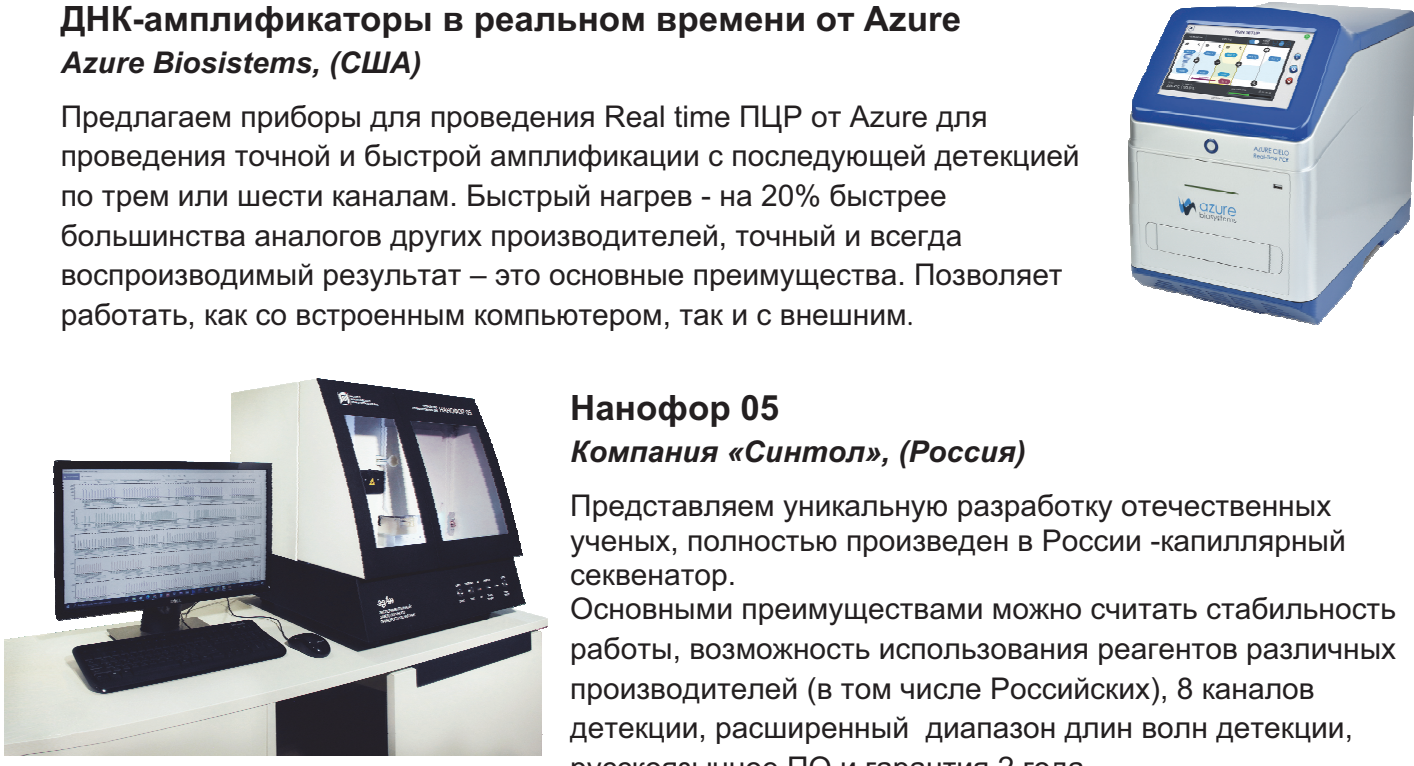

\section{Нанофор 05 Компания "Синтол», (Россия)}

Представляем уникальную разработку отечественных ученых, полностью произведен в России -капиллярный секвенатор.

Основными преимуществами можно считать стабильность работы, возможность использования реагентов различных производителей (в том числе Российских), 8 каналов детекции, расширенный диапазон длин волн детекции, русскоязычное ПО и гарантия 2 года. 


\section{GenScript}

Make Research Easy

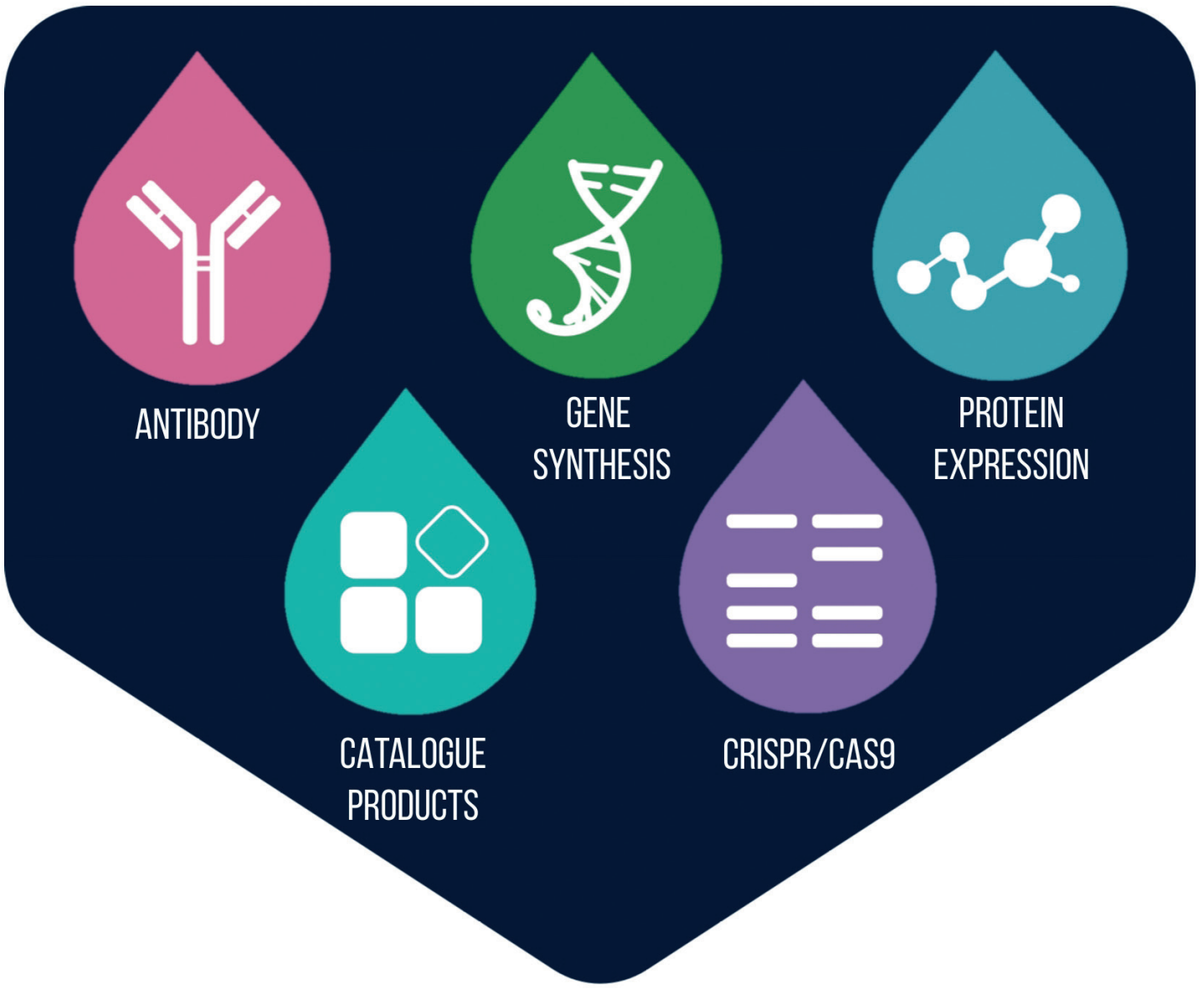

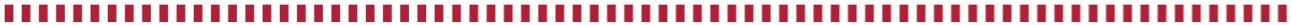

Ваше универсальное решение для исследований в области наук о жизни

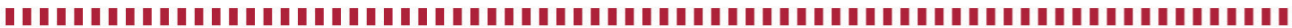

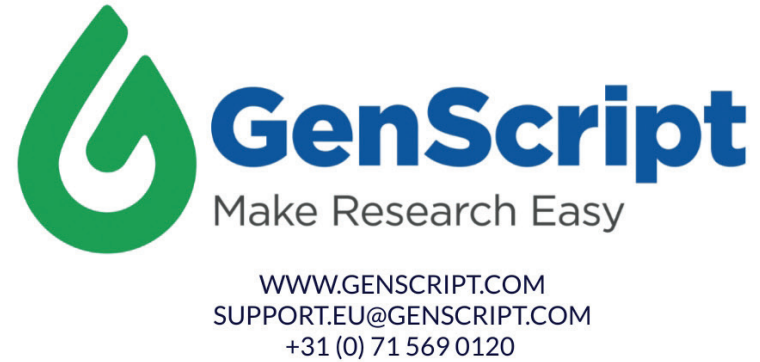




\section{eppendorf}

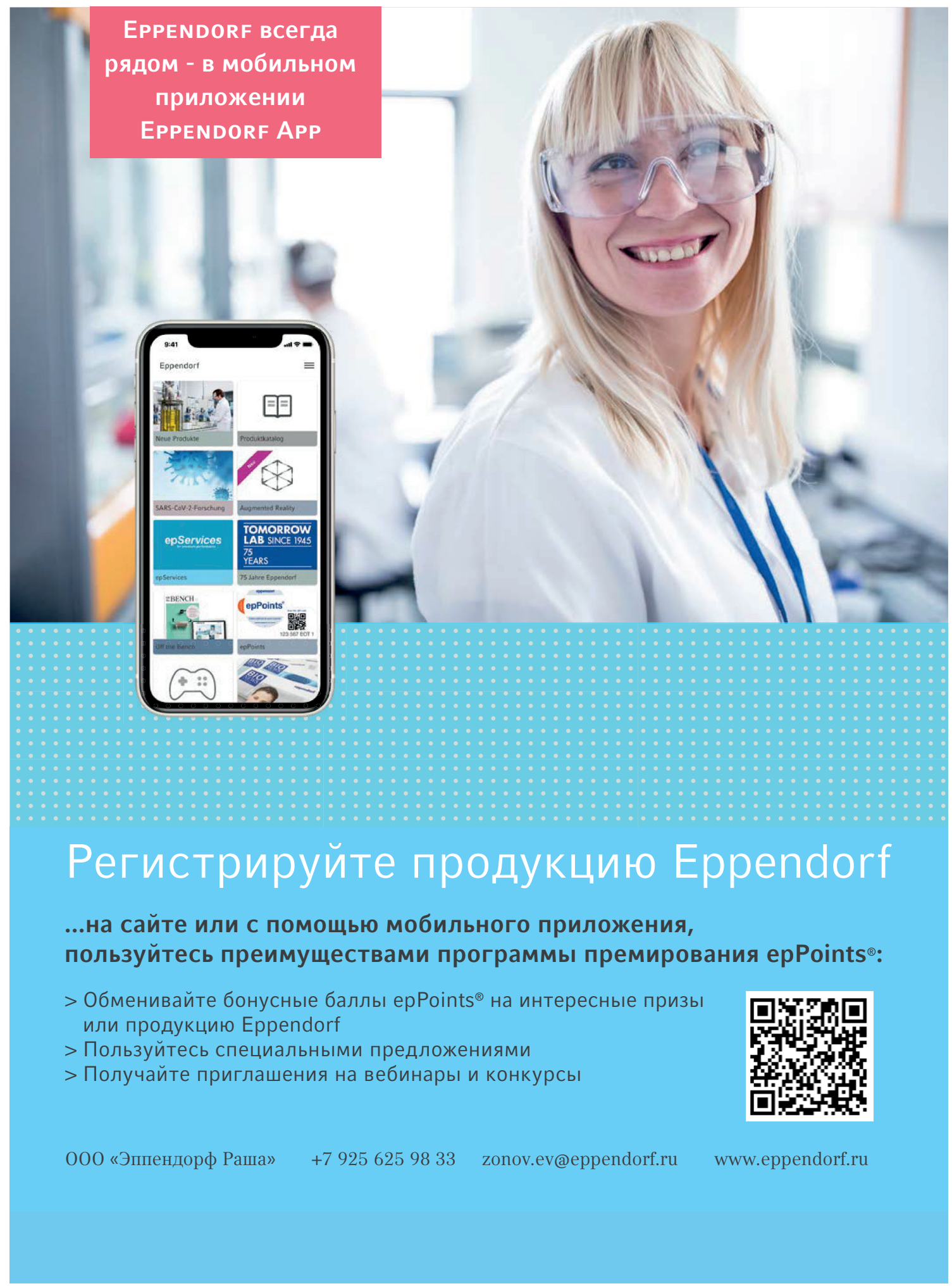




\section{weisstechnik \\ a schunk company}

\section{Fitotron $^{\circledR}$. Климатические камеры роста растений}

Компания ООО «Вайсс Климатехник» является ведущим разработчиком, производителем и поставщиком компактных климатических камер роста (вегетационных шкафов), больших климатических камер роста и камер со стеллажами, а также климатических камер с контролируемой средой. Они используются для исследований растений, инкубации насекомых, выращивания культур клеточных тканей растений и компонентов для фармацевтических препаратов растительного происхождения.

Компания Weiss Technik долгие годы занимается производством оборудования под маркой fitotron ${ }^{\circledast}$ для растениеводства и энтомологии для использования в лабораториях и научно-исследовательских учреждениях.

Лабораторные камеры роста тип SGC и HGC

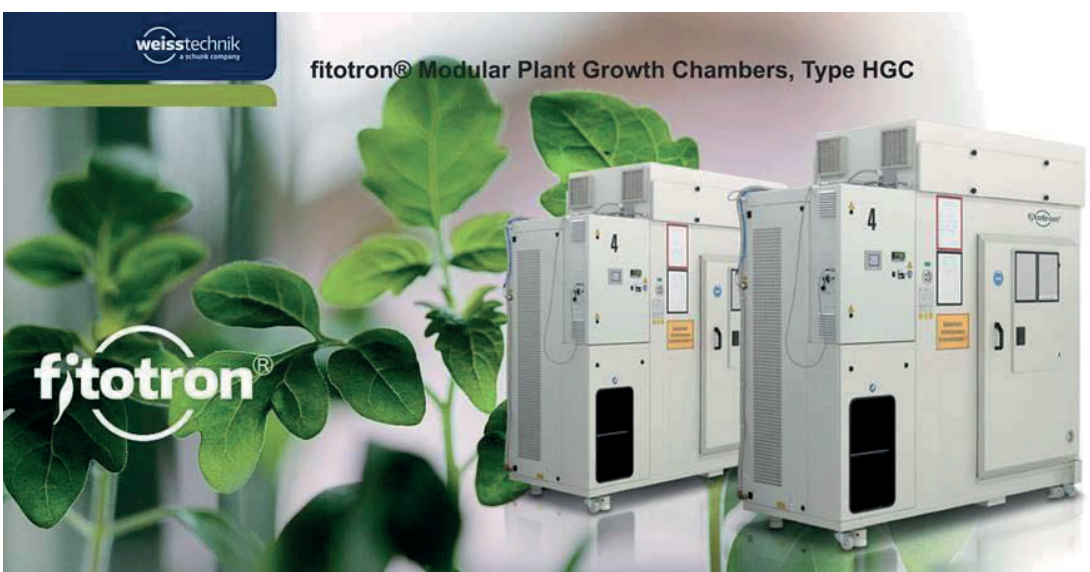

Климатические камеры Fitotron ${ }^{\circledast}$ SGR большого объема для растений и насекомых

Эти камеры оснащены необходимыми устройствами и функциями для исследования растений и насекомых, имеют освещаемые полки и регулируемую подачу свежего воздуха. Очень точное регулирование климатических условий при низкой скорости воздушного потока достигается при помощи горизонтальной подачи кондиционированного воздуха через большие боковые стенки.

Преимущества нашего оборудования:

- До трёх вертикальных уровней для культивирования растений (возможно использовать дополнительные уровни)

- Площадь культивирования растений 1,2-24,5 м²

- Освещаемые полки, легко регулируемые по высоте

- Доступны 63 различных размера камер и специальные исполнения

- Флуоресцентные лампы с регулируемой яркостью и/ или светодиодные модули

- Источники освещения доступны с фиксированным и с переменным спектром излучения

ООО «Вайсс Климатехник»

ул. Летниковская д. 10 стр. 4

115114 Москва, Россия

+74957872043

www.weiss-technik.ru

Контактное лицо: Екатерина Таран

ekaterina.taran@weiss-technik.com
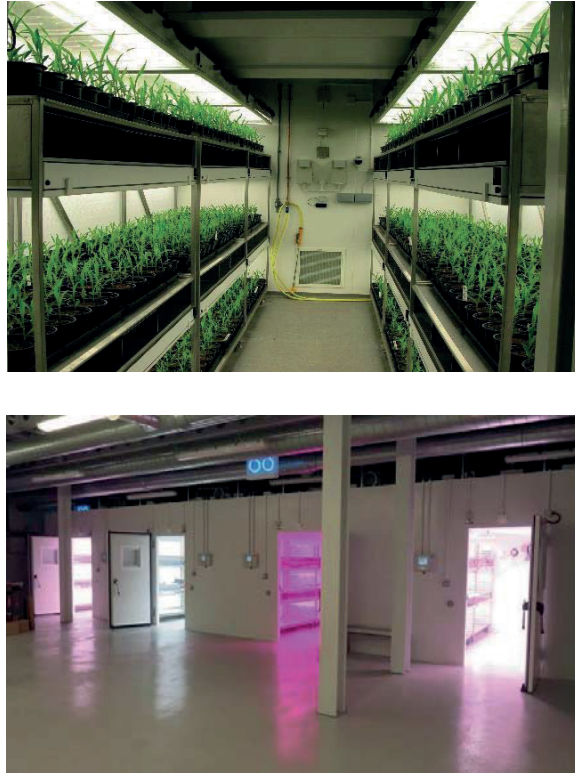


\section{MERCK}

\section{YYEFHOLE}

पㅋ.TTPb! MERCK

\section{БАЗА ДЛЯ ВАШИХ} ИССЛЕДОВАНИЙ

MILLIPLEX MAP

Multiplex Assays

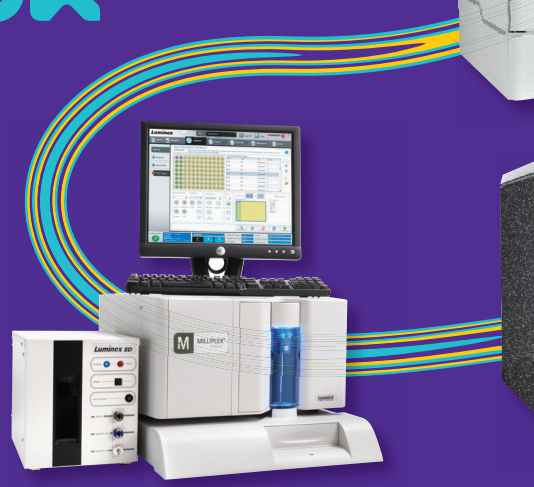

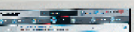

한.

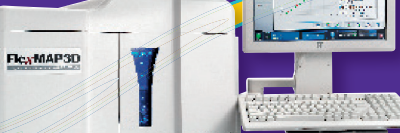

bisting

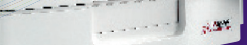

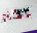

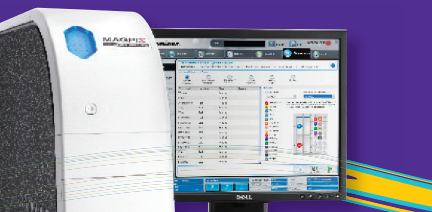

Вы сможете осуществить бесплатную постановку наборов MILLIPLEX` с помощью специалиста компании Merck или локального тренера:

- Для выбора даты и базы (город/институт) постановки обратитесь, пожалуйста, к Марине Прохоровой по телефону +79101426177 или электронной почте: marina.prokhorova@merckgroup.com

- Для выбора панели ознакомьтесь, пожалуйста, с каталогом наборов, а также промо-предложением на 2021 год (на обороте).

- Каталог наборов можно получить по электронной почте или запросить бумажный экземпляр у сотрудника_компании.
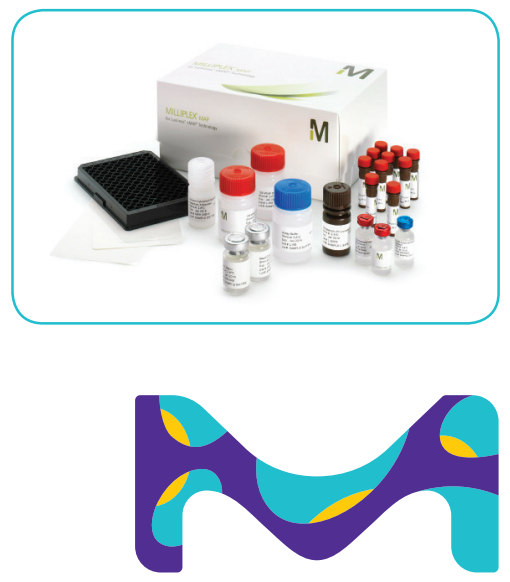


\section{Фрагментный анализ ДНК, РНК и белков Системы капиллярного электрофореза Osep}

BiOptic

Скрининг ПЦР-продуктов. Генотипирование. Количественный и качественный анализ

библиотек для NGS и нанопорового секвенирования. Анализ фрагментированности

геномной ДНК. Анализ внеклеточной ДНК. Анализ олигонуклеотидов. Анализ

продуктов рестриктазного расщепления. Анализ концентрации и целостности РНК

\section{(RNA Quality Number)}

Автоматические системы капиллярного электрофореза Qsep сконструированы для быстрого фрагментного анализа нуклеиновых кислот. Все этапы электрофореза - заливка геля, нанесение образцов, разделение фрагментов, визуализация и анализ результатов - в одном приборе в одну стадию! Электрофорез происходит в картридже, внутри которого находится капилляр, заполненный гелем с флуорофором для детекции биомолекул. Процесс разделения фрагментов отражается в реальном времени. Анализ результатов производится с помощью ПО Q-Analyzer (в комплекте поставки).
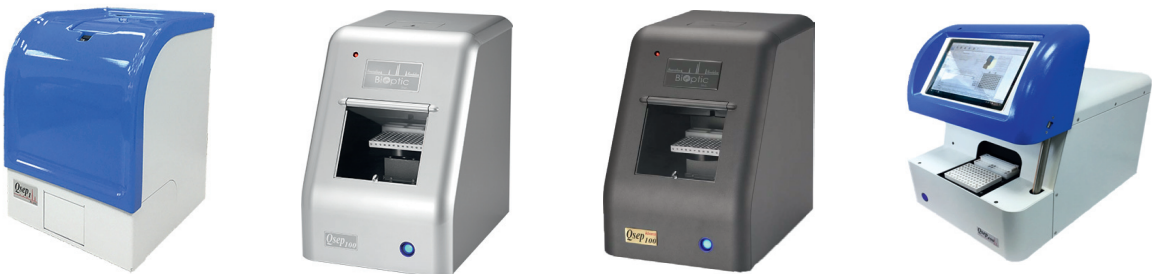

- Автоматическая подача образцов (от 1 до 96);

- несколько типов картриджей для разных молекул (фрагментированная ДНК, геномная ДНК, PHК, белки), рассчитанных на анализ 100-300 образцов;

- время анализа одного образца - от 2 до 7 минут;

- разрешение - 1-4 нуклеотида (в диапазоне длин от 100 до 500 нуклеотидов);

- чувствительность - от 100 пг/мкл;

- объём образца - 1 или 20 мкл, из которых в капилляр вводится 1 пл;

- визуализация, количественный и качественный фрагментный анализ с помощью ПО;

- низкая стоимость анализа - от 15 рублей за образец.

\begin{tabular}{|c|c|c|c|}
\hline & Qsep1 & Qsep100 & Qsep400 \\
\hline Тип прибора & портативный & \multicolumn{2}{|c|}{ стационарный } \\
\hline Детекция & \multicolumn{3}{|c|}{ флуоресцентная } \\
\hline Связь с ПК & $\mathrm{Wi}-\mathrm{Fi}$ & \multicolumn{2}{|c|}{ USB } \\
\hline Ток разделения & $1-8 \mathrm{~KB}$ & \multicolumn{2}{|c|}{$1-15 \mathrm{~KB}$} \\
\hline Картридж & \multicolumn{2}{|c|}{ 1-капиллярный } & 4-капиллярный \\
\hline Автосэмплер & 1-12 образцов & \multicolumn{2}{|c|}{ 1-96 образцов } \\
\hline
\end{tabular}

\section{0 «Диаэм»}

Новосибирск

пр. Академика

Лаврентьева, д. 6/1

тел.

(383) 328-0048

nsk@dia-m.ru
Казань

ул. Парижской

Коммуны, д. 6

тел.

(843) $210-2080$

kazan@dia-m.ru
Москва

ул. Магаданская, А. 7, к. 3 . тел./факс: (495) 745-0508 . sales@dia-m.ru

С.-Петербург

ул. Профессора

Попова, д. 23

тел.

(812) $372-6040$

spb@dia-m.ru

\section{Ростов-} на-Дону пер. Семашко, д. 114 тел. (863) 303-5500 rnd@dia-m.ru

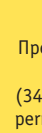

Пермь Представитель тел. (342) 202-2239 perm@dia-m.ru

Воронеж Представитель

тел.

(473) 232-4412 armenia@dia-m.ru Warw.dia-m.Pณ

Армения
Представитель
тел.
(094) 01-0173
armenia@dia-m.ru

Узбекистан Представитель (90) (90) 354-8569 uz@dia-m.ru 


\title{
Molecular analysis of sugar beet samples using the RAPD method
}

\author{
Abekova A.M.*, Yerzhebayeva R.S., Bazylova T.A., Babisekova D.I., \\ Amangeldiyeva A.A., Bastaubayeva Sh.O., Konusbekov K.T. \\ Kazakh Research Institute of Agriculture and Plant Growing, Almalybak, Kazakhstan \\ *email:aabekova@mail.ru
}

Cultivar fingerprinting in various plant species employs a range of marker systems. Creation of source material of sugar beet with new traits and properties is a challenging task. Success is dependent on diversity and the level of insight into the genetics of the plant material. The main priority for modern sugar beet breeding is to establish a diverse genetic basis of sources. Development and introduction of new varieties and hybrids puts additional demand on scientifically rigorous selection of the material, its evaluation by molecular genetic markers that are up to the modern technical standards. Here at KazRIAPG we have conducted a study of 50 samples of hybrids and lines of sugar beet with RAPD markers. Results showed that all of the studied samples expressed certain unique features in their banding pattern, attributed to presence or absence of particular DNA fragments. Polymorphism ranged from 17 to $87 \%$, the number of detected loci from 2 to 17 and the size of the bands from 210 to $2850 \mathrm{bp}$. Clustering of the samples based on presence or absence of certain bands was performed in R 4.0.3 and had grouped the breeding material into distinct clusters that reflected the origin of the samples. The maximal Binary distance between the samples was 1.4. This was the joining distance of two clusters, one containing CMS lines: CHS 1611, CHS 1631, CHS 97, MS 2113 and the other containing the pollinator lines VP-23 and VP-44. Samples identified as genetically distinct are recommended to be included into crosses to create highly productive sugar beet hybrids. Based on data, the molecular genetic profiles reflecting the genetic structure of the individual sugar beet materials were compiled. Genotyping of sugar beet will streamline the analysis of the crosses and fingerprinting would protect the intellectual rights of breeders whilst also allowing to better control the uniformity of germplasm. 


\title{
The studying genetic regulation of the vaviloid type of spike branching in hybrid lines of hexaploid wheat
}

\author{
Adonina I.G. ${ }^{1 *}$, Zorina M.V. ${ }^{1,2}$, Shcherban A.B. ${ }^{1}$, Mehdiyeva S.P. ${ }^{3}$, Salina E.A. ${ }^{4}$ \\ ${ }^{1}$ Institute of Cytology and Genetics, SB RAS, Novosibirsk, Russia \\ ${ }^{2}$ Novosibirsk State University, Novosibirsk, Russia \\ ${ }^{3}$ Genetic Resources Institute of ANAS, Azerbaijan \\ ${ }^{4}$ Kurchatov Genomic Center of the Institute of Cytology and Genetics, SB RAS, Novosibirsk, Russia \\ *email: adonina@bionet.nsc.ru
}

Prolonged spikelet axes with additional flowers is observed in case of vaviloid type of spike branching in wheat. Forms with a vaviloid type of spike can occur as a result of distant hybridization. This trait is poorly researched. We studied lines obtained in Genetic Resources Institute of ANAS by crossing triticale with the hexaploid wheat Triticum aestivum L. var velutinum. Karyotyping was performed using GISH, FISH, and molecular-genetic analysis. For all plants with vaviloid type of spike the substitution of the wheat chromosome $2 \mathrm{D}$ by the $2 \mathrm{R}$ chromosome of rye or the telocentric chromosome $2 \mathrm{RL}$ is characteristic. A part of the plants contained 1-2 additional telocentric chromosomes of wheat 2DS. Only plants of line 857 had a hexaploid wheat karyotype $(2 n=6 x=42$, BBAADD) and a standard spike morphotype. According to our hypothesis, the gene/genes suppressing the manifestation of the vaviloid type of spike branching are localized on the long arm of chromosome 2D. As known from previous studies by other authors, some mutations in the gene $Q$ which is located on the long arm of chromosome 5A cause an elongation of the spikelet axis and thereby contribute to the formation of additional flowers on the spikelet axis. We found the absence of PCR amplification with primers matched to different regions of the $Q$-gene in the studied lines with vaviloid spike branching. These may be due to the deletion of the region of chromosome 5A carrying this gene.

Acknowledgments: This work was carried out as a part of the budget project No. 02592021-0012 and was funded by RFBR, project No. 20-016-00122. 


\title{
Horizontal transfer of potato viroid PSTVd by Phytophthora infestans to and from host plants
}

\author{
Afanasenko O.S. ${ }^{1}{ }^{*}$, Khiutti A.V. ${ }^{1}$, Mironenko N.V. ${ }^{1}$, Lashina N.M. ${ }^{1}$, Matsushita Y. ${ }^{2}$ \\ ${ }^{1}$ All-Russian Institute of Plant Protection, St. Petersburg, Russia \\ ${ }^{2}$ NARO, Institute of Vegetable and Floriculture Science Tsukuba, Japan \\ * email: olga.s.afan@gmail.com
}

Potato spindle tuber viroid (PSTVd) is economically important pathogen and classified as high-risk plant quarantine disease. According to the European Plant Protection Organization (EPPO), the disease has been reported in 37 countries on all continents. The quarantine status of PSTVd and the possible significant losses of potato yield determine the importance of studies of various aspects of pathogen epidemiology. PSTVd is a single-stranded circular naked RNA genome, 356-363 nucleotides in length, lacking the ability to encode a protein and therefore being a parasite of the transcription mechanism of hosts. Replication of PSTVd is accompanied by the accumulation of viroid-derived small RNAs (vd-siRNAs) proposed to play a central role in disease symptom development. PSTVd is transmitted mechanical, by aphids, through pollen to progeny seeds and to other plants of potato and tomato. The aim of study was to identify a possible role of Phytophthora infestans in the transmission of PSTVd to potato and tomato plants. Three potato cultivars Gala, Riviera and Colomba were inoculated with strain PSTVd VP87. After 60 days post inoculation RT PCR diagnostic showed presence of PSTVd in these cultivars. Inoculation of PSTVd infected potato plants with $\mathrm{Ph}$. infestans isolate VZR18 was conducted. After the onset of late blight symptoms reisolation on rye agar of $\mathrm{Ph}$. infestans from infected plants was done. Positive diagnostic of PSTVd by RT-PCR in culture Ph. infestans after 1, 2, and 3 passages was showed. Two months after inoculation with $\mathrm{Ph}$. infestans isolate infected with PSTVd of healthy tomato plants RT-PCR revealed a 360-bp amplification product, indicating successful infection of plants. This is the first proof of horizontal transfer of PSTVd by Phytophthora infestans to and from host plants.

Acknowledgments: The research was supported by a grant from the Russian Science Foundation No. 20-46-07001. 


\title{
Modeling of flowering time in mungbean with Approximate Bayesian Computation
}

\author{
Ageev A.Yu. ${ }^{1}$, Lee C.-R. ${ }^{2}$, Ting C.-T. ${ }^{2}$, Schafleitner R. ${ }^{3}$, Bishop-von Wettberg E. ${ }^{4}$, \\ Nuzhdin S.V. ${ }^{1,5}$, Samsonova M.G. ${ }^{1}$, Kozlov K.N. ${ }^{1 *}$ \\ ${ }^{1}$ Peter the Great St. Petersburg Polytechnic University, St. Petersburg, Russia \\ ${ }^{2}$ National Taiwan University, Taipei, Taiwan \\ ${ }^{3}$ World Vegetable Center, Tainan, Taiwan \\ ${ }^{4}$ Department of Plant and Soil Science, University of Vermont, Burlington, VT, USA \\ ${ }^{5}$ University of Southern California, Los Angeles, CA, USA \\ *email: kozlov_kn@spbstu.ru
}

Mungbean (Vigna radiata (L.) Wilczek) is an important legume in many temperate regions. Its flowering time is a critical trait to achieve crop efficiency. We used 778 samples of 296 genotypes from 18 countries from the mungbean WorldVeg minicore collection and Approximate Bayesian Computation to construct the new dynamic mathematical models for flowering time under control of daily values of maximum and minimum temperature, precipitation, day length and solar radiation. It was shown that 12 and $19 \%$ of the variation in flowering time is explained by the interaction of climatic factors with the country of origin or genotype respectively. Comparison of the influence of climatic factors on groups of plants originating from different countries or carrying different combinations of alleles showed statistically significant differences in most cases, which additionally confirms the influence of the country of origin and genotype on plant phenology. Model forecasts for future years till 2030 for Taiwan showed that although the flowering time decreases for all accessions, different groups respond differently to the same climate change scenarios, these differences are determined by different impacts of climatic factors. For the refined model, it was shown that an increase in the daily maximum temperature from 0 to 2 degrees in 0.25 increments can cause two types of reactions - a decrease in the flowering time observed in most samples, and its growth revealed for individual values of the maximum temperature perturbation in a group of samples, which can be caused by insufficient watering.

Acknowledgments: The research was funded by the Ministry of Science and Higher Education of Russia as part of World-class Research Center program: Advanced Digital Technologies (contract No. 075-15-2020-934 dated 17.11.2020). 


\title{
Study of the relationship between the conductive system of the internodes in spring bread wheat with lodging resistance and yield traits
}

\author{
Ageeva E.V. ${ }^{*}{ }^{\text {, Leonova I.N. }}{ }^{2}$, Salina E.A. ${ }^{2}$ \\ ${ }^{1}$ Siberian Research Institute of Plant Production and Breeding - Branch of the Institute of Cytology and \\ Genetics, SB RAS, Novosibirsk, Russia \\ ${ }^{2}$ Institute of Cytology and Genetics, SB RAS, Novosibirsk, Russia \\ *email: elenakolomeec@mail.ru
}

Lodging is one of the main problem of reduced productivity of spring bread wheat which can lead to the grain germination and reduced grain quality. Quantitative parameters of the conducting system of the under-ear and second-from-top internodes (the number and diameter of vascular bundles of the parenchymal layer of the stem, the diameter of the internode, the thickness of the mechanical layer thickness and the thickness of the straw) were determined in 11 varieties of spring bread wheat. For this purpose the method of assessing the level of development of the conducting system of the ear internode we used.

The correlations of anatomical and morphological characteristics with the yield, grain quality and resistance to lodging has been found. In the studied genotypes yield varied from 3.51 (Bel) to 5.83 t/ha (Obskaya 2). The most productive varieties originated from mid-ripening (Novosibirskaya 18 and Obskaya 2) and mid-late ripening groups (Triso). The yield of early-maturing varieties was estimated at the level of the average value, which indicates their high potential in the prevailing environments. Three varieties (Velut, Bel and Obskaya 2) had an excess in number of vascular bundles of the parenchymal layer. The Obskaya 2, Velut and Novosibirskaya 18 prevailed over the other wheat varieties in the mechanical layer thickness. It was shown that diameter of the under-ear internode was more than $2 \mathrm{~mm}$. The largest diameter EN1 was recorded in varieties Novosibirskaya $16(3.02 \mathrm{~mm})$, Velut $(2.74 \mathrm{~mm})$ and Novosibirskaya 31 $(2.91 \mathrm{~mm})$. EN2 diameter varied from 2.45 to $4.07 \mathrm{~mm}$. Novosibirskaya 16 was characterized as the thickest among the studied varieties; the diameter of EN2 was $4.07 \mathrm{~mm}$. In general, most of the varieties had good indicators of gluten and protein content. The highest gluten content were shown for the early ripening varieties Novosibirskaya 15 and Novosibirskaya 16 (32.4 and 33.4\% respectively). Analysis of the relationship between anatomical and morphological traits, yield, and grain protein content revealed parameters that correlate with lodging resistance (thickness of the straw and mechanical layer thickness). Obtained results also point to correlation between number of conductive bundles and mechanical layer thickness and the traits that can cause high ear productivity.

Acknowledgments: The anatomical study of the wheat stem was carried out with the support of the budget project of the Institute of Cytology and Genetics, SB RAS No. 0259-2021-0018. The study of protein and gluten content was carried out with the financial support of the Russian Science Foundation grant No. 21-76-30003. 


\title{
Lipopeptide producing endophytic bacteria of the genus Bacillus in the regulation of the expression of genes involved in the defense response of wheat against greenbug aphid Schizaphis graminum
}

\author{
Alekseev V.Y., Shein M.Yu., Veselova S.V., Burkhanova G.F., Maksimov I.V. \\ Institute of Biochemistry and Genetics of the UFRC of the RAS, Ufa, Russia \\ * email: valentin-1994@yandex.ru
}

Plant growth-promoting bacteria (PGPB), which produce various metabolites with antibiotic activity, are able to suppress the development of pests, both through direct antagonism and indirectly, through the mechanism of triggering induced systemic resistance (ISR). To date, the mechanism of action of bacterial lipopeptide on the plant defense system is just beginning to be studied. ISR induced by endophytic bacteria leads to a change in the redox status of plants and, as a result, to a change in the expression of genes encoding PR-proteins (from pathogenesis related proteins). Cellular factors such as Dicer-like (DCL) and Argonaute (AGO), which are involved in gene silencing, also induce systemic immunity to various pathogens through the regulation of $P R$ genes and their protein products. However, their role in these processes is not sufficiently studied. In our work, we studied three strains of endophytic bacteria Bacillus subtilis 26D, B. subtilis 11BM, and B. thuringiensis B-6066 from the All-Russian collection of industrial microorganisms, producing the lipopeptides surfactin, iturin, and fengicin respectively. And two B. subtilis Tas-1 and Tas-8.2 isolates excreted from the internal tissues of wheat plants. Both isolates produced surfactin. All bacterial strains and their metabolites exhibit insecticidal activity against the greenbug aphid $S$. graminum under direct exposure. During indirect action, the strains synthesizing surfactin and fengicin, but not iturin, had the greatest effect on the viability of greenbug aphid and the endurance of wheat plants. They also induced systemic resistance, which was manifested in the accumulation of hydrogen peroxide, increased activity of peroxidases, and the accumulation of transcripts of genes encoding PR-proteins markers of the salicylate and jasmonate signaling pathways $(P R-1, P R-2, P R-3, P R-6, P R-9)$ and genes of cellular factors DCL (DCL2, DCL4) and AGO (Agol, Ago2, Ago3).

Acknowledgments: This work was supported by the RFBR projects No. 20-316-90021 and 20-316-90004. 


\title{
Association mapping of quantitative trait loci for agronomic traits in spring wheat collection tested under two water regimes in Northern Kazakhstan
}

\author{
Amalova A. ${ }^{1,2 *}$, Abugalieva S. ${ }^{1,2}$, Babkenov A. ${ }^{3}$, Babkenova S. ${ }^{3}$, Turuspekov Y. ${ }^{1,2}$ \\ ${ }^{1}$ Institute of Plant Biology and Biotechnology, Almaty, Kazakhstan \\ ${ }^{2}$ Al-Farabi Kazakh National University, Almaty, Kazakhstan \\ ${ }^{3}$ A.I. Barayev Research and Production Centre for Grain Farming, Shortandy, Akmola region, \\ Kazakhstan \\ * email: akerke.amalova@gmail.com
}

Bread wheat is the most important cereal in Kazakhstan, where it grows on over 12 million hectares. One of the major constraints in the grain yield of wheat is a drought caused by a limited water supply. Hence, the development of drought-resistant cultivars will be critical for ensuring food security in this country. Therefore, identifying drought resistance-associated quantitative trait loci (QTLs) is an essential step in modern breeding activities that also rely on a marker-assisted selection approach. In this study, the collection of 179 spring wheat accessions were tested under irrigated and rainfed conditions in Northern Kazakhstan by using growth-related traits (heading date (HD), seed maturation date (SMD), plant height (PH), and etc.), and yield components, during three years (2018-2020). The collection was genotyped using a 20000 (20K) Illumina iSelect SNP array, and 8662 polymorphic SNP markers were selected for genome-wide association study (GWAS) to identify QTLs for targeted traits. Forty-six stable QTLs out of 237 total QTLs were identified for irrigated and rainfed conditions in the Akmola region, Northern Kazakhstan, by studying eight traits, including HD, SMD, PH, and grain yield components. Identified SNP markers of QTLs for studied traits can be directly utilized to develop new competitive spring wheat cultivars in Northern Kazakhstan. It was confirmed that GWAS is a powerful method in searching genes associated with the regulation of key agronomic traits in bread wheat.

Financial support: ИРН АР08855387 «Nested association mapping for gene discovery and deployment for improvement of yield, quality, and disease resistance in bread wheat» from the Ministry of Education and Science of the Republic of Kazakhstan. 


\title{
Protein structure and function analysis for plant stress tolerance on BTB/POZ genes
}

\author{
Anashkina A.A. ${ }^{1}$, Luzin A.N. ${ }^{2}$, Kulikova D.K. ${ }^{2}$, Dergilev A.I. ${ }^{2}$, Orlov Y.L. ${ }^{2,3,4 *}$ \\ ${ }^{1}$ Engelhardt Institute of Molecular Biology RAS, Moscow, Russia \\ ${ }^{2}$ Novosibirsk State University, Novosibirsk, Russia \\ ${ }^{3}$ Peoples' Friendship University of Russia (RUDN University), Moscow, Russia \\ ${ }^{4}$ Institute of Cytology and Genetics, SB RAS, Novosibirsk, Russia \\ *email: orlov@bionet.nsc.ru
}

The DNA sequencing has allowed us to determine the full genomes of many plants, including model organisms such as Arabidopsis thaliana, scientifically interesting species of flowering plants, trees, and economically important crops such as rice, maize, soy, cotton, and wheat. Developments in omics technologies have enabled unprecedented views of plants across scales, from the molecular to the ecosystem level, demanding integration of large, noisy, and heterogeneous data sets. There are several bioinformatics modeling fields in plants: Detailed analysis of regulatory elements of gene expression (transcription factors, regulatory regions, chromatin state, alternative splicing mechanisms); Methods to discern differences among members of a gene family, particularly large homologous gene families, and to identify gene copies likely to be functionally redundant; computational modeling of high-resolution molecular structures of proteins/enzymes and assemblies with to identify and prioritize structural features affecting plant cell response to environment conditions (stress tolerance). The expression analyses showed that the defending type drought stress tolerance contributing LAN C like protein GCL-2 is expressed in providing disease resistance and myb linked $\mathrm{BTB} / \mathrm{POZ}$ genes contribute for high yielding of pigeonpea. BOP is a member of BTB group of plant protein. The BOP genes encode proteins containing a BTB/POX virus and zinc finger (POZ) domain and ankyrin repeat. BLADE-ON-PETIOLE 1 (BOP1) and BOP2 encoding genes are redundant transcription factors restricted to the base of developing lateral organs including the leaf and floral development. Regulatory network inference is a prime example of the usefulness of bioinformatics in plant sciences. Recent examples are the inference of tissue-specific gene regulatory networks in maize, of a dynamic gene regulatory network related to nitrogen use efficiency in Arabidopsis, and of regulatory networks coordinating timing and rate of gene expression in response to environmental signals in rice. Putative encoding region of transit peptides and mature proteins from different plant genomes were predicted using Blast2go. Domain Prediction of lanc-like protein GCL2 and BOP gene in Cajanus was done by NCBI CD-search software. Fasta sequence of BOP genes was retrieved from NCBI followed by Blast search. RaptorX structure prediction tool was used to analyze distantly related template proteins (especially those with sparse sequence profiles) and quality of the alignment. We discussed the structural protein models obtained. Unraveling the effects of genotypic variation on protein structure provide fundamental insights into the regulation of plant development and physiology and the ability to predict yield and quality traits. 


\section{Identification and characterization of the thaumatin-like genes in garlic}

Anisimova O.K. ${ }^{1,2 *}$, Filyushin M.A. ${ }^{2}$

${ }^{1}$ Lomonosov Moscow State University, Moscow, Russia

${ }^{2}$ Research Centre of Biotechnology RAS, Moscow, Russia

*email:lelikanis@yandex.ru

Significant yield losses of crops, including garlic Allium sativum, are associated with fungal infections, in response to which pathogenesis-related proteins (PRs) are synthesized. Thaumatin-like proteins (TLPs), that belong to one of 17 known families of PR proteins - PR5, are involved in plant responses to fungal infections. In this study, thaumatin-like proteins genes were identified and characterized in A. sativum genome, and their expression was determined in response to fungus Fusarium proliferatum infection.

In A. sativum cv. Ershuizao genome (PRJNA606385) 32 sequences encoding thaumatinlike proteins were identified. The sizes of the found genes varied from 615 to $2572 \mathrm{bp}$ and the corresponding amino acid sequences included from 204 to 323 aa. Phylogenetic relationships were established and five subclusters of AsTLPs were identified. The presence of various $c i s$-regulatory elements associated with responses to phytohormones and stress factors was predicted in AsTLPS genes promoter regions. AsTLPs gene expression patterns were determined in the roots, stems, and cloves of two garlic cultivars - Sarmat and Strelets (resistant and susceptible to fusarium rot respectively) in response to $F$. proliferatum infection. In general, the AsTLPS expression showed significantly more intensive changes in response to the infection in cv. Sarmat than in cv. Strelets. For the majority of AsTLPs genes, an increase in expression was found in response to $F$. proliferatum infection. In roots of cv. Sarmat, the expression of AsTLP8, AsTLP24, and AsTLP27 increased by many times in 96 hours after the infection. The least pronounced increase in expression in response to the infection was observed in cloves, which is probably associated with the penetration of the pathogen through the roots, where the response was the highest. For differentially expressed AsTLPs genes, promoter regions (1000 bp) were identified and investigated. The obtained results indicate the active participation of AsTLPs genes in the response to $F$. proliferatum infection and in the resistance formation of garlic plants to fusarium rot.

Acknowledgments: This work was supported by the RFBR grant No. 20-316-70009. 


\title{
Phenotyping of soft spring wheat varieties to expand the genetic diversity of cultivars resistant to biotic factors
}

\author{
Aparina V.A. ${ }^{1,2 *}$, Boyko N.I. ${ }^{2}$, Morozova E.V. ${ }^{2}$, Sukhomlinov V.Yu. ${ }^{2}$, Piskarev V.V. ${ }^{2}$ \\ ${ }^{1}$ Novosibirsk State Agrarian University, Novosibirsk, Russia \\ ${ }^{2}$ Siberian Research Institute of Plant Production and Breeding - Branch of the Institute of Cytology and \\ Genetics, SB RAS, Novosibirsk, Russia \\ *email: aparinava@bionet.nsc.ru
}

\begin{abstract}
N.I. Vavilov wrote that the introduction of immune varieties into the culture or their creation by selection is the most radical instrument of protection against various diseases caused by parasitic fungi, bacteria, viruses. The effectiveness of using resistant wheat cultivars is high at present, especially when the resistance of the cultivar to diseases is harmonized with other agronomic characteristics. The study of 70 collection varieties of soft spring wheat (Triticum aestivum L.) of the mid-late maturity group was carried out in 2018-2019. Suitable weather conditions for the development and manifestation of the studied phytopathogens were in the years of study. The high natural spread of powdery mildew observed in 2019, which allowed us to assess the reaction of varieties in different degrees of resistance. The weather in August was favorable for the formation of the high thousand grain weight of the studied cultivars. In 2019, the thousand grain weight (the average values for the group in $2018-38.3 \mathrm{~g}$ and $2019-39.5 \mathrm{~g})$ and the yield $(286.6$ and $473.5 \mathrm{~g} / \mathrm{m}^{2}$ ) of the studied varieties were higher than in 2018 . Twenty varieties that are resistant to powdery mildew (Blumeria graminis), leaf (Puccinia triticina) and stem (Puccinia graminis) rust to varying degrees and have productivity characteristics (thousand grain weight and yield) at the level of the Sibirskaya 17 (standard) were characterized as sources of resistance to biotic factors: Obskaya 2, Ekada 6, Pyramida, Pamyati Ryuba, Riks, Rh 24, Chernozemnouralskaya, Ekada 113, Yugo-Vostochnaya 4, Tulaykovskaya 5, Margarita, Lutescens 505, Omskaya 38, Weawer, Tulaykovskaya 108, RL 345, Mertsana, Voevoda, Tulaykovskaya 10, Ekada 85. The resistance of varieties to pathogens was determined mainly by such genes as: $\operatorname{Lr} 9, \operatorname{Lr} 19, \operatorname{Lr} 24, \operatorname{Lr} 26$; $S r 25$; PmBel, PmAg.i.1, PmAg.i.2, Pm38.
\end{abstract}

Acknowledgments: This work was supported by RFBR, project number 20-016-00093. 


\title{
Resistance to common bunt of bread wheat in the Middle Volga region of Russia
}

\author{
Askhadullin Danil F.*, Askhadullin Damir F., Vasilova N.Z. \\ Tatar Scientific Research Institute of Agriculture, FRC Kazan Scientific Center RAS, Kazan, Russia \\ *email: danil.askadullin@knc.ru
}

In the conditions of the Middle Volga common bunt is caused by two closely related fungi, Tilletia caries (D.C.) Tul. \& C. Tul. and T. laevis J.G. Kühn. Common bunt is considered a non-essential disease in conventional agriculture, since the spores of the fungus are well suppressed by chemical fungicides during pre-sowing etching. However, when conducting low-input and organic farming, grain producers can face significant losses from this disease. The local population structure of this pathogen is changing. Widely cultivated in the Middle Volga region varieties: Simbirzit, Zlata, Margarita, Ekada 70, Ekada 66, Ekada 109 had a high resistance to common bunt, but by now their resistance is greatly reduced. The favorable infectious background for studying the degree of damage to common bunt in the field largely depends on the favorable temperatures for the germination of bunt spores. Such conditions were observed in 2018 and 2020. Against an infectious background, with artificial inoculation of seeds with common bunt spores circulating on common wheat in the middle Volga region of Russia (on average for 2018,2020 ), only $3.3 \%$ of widely distributed varieties and promising lines can be characterized as having high resistance to common bunt. These samples had less than $6 \%$ of the plants with signs of the disease. The absence of signs of the disease was noted only in the variety 100-let-TASSR. The study of samples carrying the main Bt 1-10 genes against such an infectious background shows that the Bt5, Bt8 and Bt10 genes continue to work effectively. In samples carrying the Bt10 gene, there are no signs of the disease. 


\section{Resistance to powdery mildew of common wheat in the Middle Volga region of Russia}

Askhadullin Damir F. ${ }^{1 *}$, Askhadullin Danil F. ${ }^{1}$, Vasilova N.Z. ${ }^{1}$, Khusainova I.I. ${ }^{1}$, Bagavieva E.Z. ${ }^{1}$, Tazutdinova M.R. ${ }^{1}$, Zuev E.V. ${ }^{2}$

${ }^{1}$ Tatar Scientific Research Institute of Agriculture, FRC Kazan Scientific Center RAS, Kazan, Russia

${ }^{2}$ FRC N.I. Vavilov All-Russian Institute of Plant Genetic Resources (VIR), St. Petersburg, Russia

* email: damir.askhadullin@knc.ru

Powdery mildew of wheat is caused by the obligate, biotrophic fungus Blumeria graminis f. sp. tritici. This pathogen is found in most regions of the world where wheat is cultivated. Crop losses from this disease can be a third, while the protein content in the grain is reduced. The population structure of this pathogen undergoes rapid changes, and is also spatially heterogeneous. In the conditions of the Republic of Tatarstan located in the Middle Volga region of Russia, the mass development of powdery mildew on common wheat is noted annually. All varieties recommended for cultivation in Tatarstan are susceptible to this disease, only the Sitara (Tatarstan, Russia) variety is high-resistant. For 10 years (2011-2020) field resistance to powdery mildew was studied in 582 samples of common wheat. It is shown that this pathogen, in our conditions, is characterized by variability and rapid evolution. Almost all samples of common wheat have lost their absolute stability over the years, but some samples retain high field stability. These varieties are: Tybalt (k-64897, Netherlands), Cytra (k64470, Poland), CH Rubli (k-65003, Germany), Visa (k-64390, Belarus), Cub (k-62510, GB). In the new arrival of common wheat from the VIR collection, the number of consistently highresistant varieties to B. graminis has increased. These varieties are: Cadenza (k-66022, GB), Raffles (k-66023, GB), Mattus (k-66024, Germany), Michael (k-66026, Germany), Quarna (k-66035, Switzerland), SW Kungsjet (k-66036, Sweden), Sparrow (k-66090, GB), Pasteur (k-66093, Netherlands), Lavett (k-66095, Sweden), Swedjet (k-66096, Sweden), SW Kronjet (k-66097, Sweden), SW Kadrilj (k-66099, Sweden). Most of the countries where the resistant samples came from are located in the European part of the world (edge: Great Britain - Belarus), at geographical coordinates of 50-55 degrees north latitude. 


\title{
Genetic diversity of Triticum araraticum assessed using cytogenetics
}

\author{
Badaeva E.D. ${ }^{1 *}$, Özkan H. ${ }^{2}$, Kilian B..$^{3,4}$ \\ ${ }^{1}$ N.I. Vavilov Institute of General Genetics, Russian Academy of Sciences, Moscow, Russia \\ ${ }^{2}$ Department of Field Crops, Faculty of Agriculture, University of Çukurova, Adana, Turkey \\ ${ }^{3}$ Leibniz Institute of Plant Genetics and Crop Plant Research (IPK), Gatersleben, Germany \\ ${ }^{4}$ Global Crop Diversity Trust, Bonn, Germany \\ * email: katerinabadaeva@gmail.com
}

Triticum araraticum Jakubz. is wild tetraploid wheat with the genome constitution GGA $^{t} \mathrm{~A}^{\mathrm{t}}$. Distribution area of $T$. araraticum covers the northern part of the Fertile Crescent: northern Iraq, eastern and southeastern Turkey, northwestern Iran, Armenia, Azerbaijan and northern Syria. Its domesticated derivative T. timopheevii was found only in Western Georgia. Genetic variation of T. araraticum and its relationships with T. timopheevii were accessed using cytogenetic analyses. Altogether 370 genebank accessions of $T$. araraticum (representing 391 genetically distinct biotypes) and 17 T. timopheevii were scored using C-banding and 92 accessions were selected for FISH with polymorphic DNA probes pSc119.2, Spelt-1, Spelt-52. All markers revealed high genetic diversity of $T$. araraticum and broad translocation polymorphisms. Normal karyotypes were found in $44.6 \%$ of $T$. araraticum accessions, whereas $55.4 \%$ accessions carried chromosomal rearrangements, represented by 76 variants. These were single (44 variants) and multiple translocations (24), paracentric (1) and pericentric (7) inversions. Translocation spectra were specific for different geographical regions. Irrespective of karyotype structure, C-banding analysis identified three well-separated clusters, which were designated ARA-0, ARA-1, and TIM, each corresponding to plastogroups G-2, G-1+G-3 and TIM, according to Mori et al. (2009). The ARA-0 group grows over the entire distribution range and exhibits the broadest genetic diversity. The ARA-1 group is found in southeast Turkey and northern Syria, where the areas of T. araraticum and T. dicoccoides overlap. Triticum timopheevii seemed to be closer related to ARA-1, than to ARA-0 group.

Acknowledgments: This work was supported by grant from the Russian State Foundation for Basic Research (project 20-04-00284). 


\title{
The heritability of carrot resistance to fungal diseases of Alternaria and Fusarium genus
}

\author{
Balashova I.T. ${ }^{1 *}$, Sokolova L.M. ${ }^{2}$, Sirota S.M. ${ }^{1}$ \\ ${ }^{1}$ Federal Scientific Vegetable Center, Moscow region, Russia \\ ${ }^{2}$ Branch of the Federal Scientific Vegetable Center, Moscow region, Russia \\ *email: balashova56@mail.ru
}

Alternaria dauci, Alternaria radicina and pathogenic species from Fusarium genus are the most damaging diseases affecting carrots (Daucus carota L.). A. dauci causes leaf blight and premature death of leaves. A. radicina causes rots 50-70\% of carrot roots during storage. Pathogenic species of Fusarium genus cause the tracheomycosis wilt, retardation growth of the plant, root and stem rots, "black leg" of seedlings. The goal of study is to obtain $\mathrm{F}_{1}$-hybrids of carrots with field resistance to the group pathogens of Alternaria and Fusarium genus. Obtaining carrot varieties and hybrids with group resistance to main pathogens is very difficult task, which is complicated by the fact that carrot resistance to fungal diseases has the polygenic control. The heritability of resistance-trait to a group of pathogens by $\mathrm{F}_{1}$-hybrids is conveniently determined with the heritability coefficient $h^{2}$, which is the only indicator determining the inclusion of genetic component to the overall variability of the trait, even at the genomic era. Resistance the basic lines of carrot to fungi of Alternaria and Fusarium genus has been studied with step by step evaluation, using several types of hard artificial and natural infection backgrounds. Tolerant samples were selected and they were used in crossings. $\mathrm{F}_{1}$-hybrids have been obtained and they have been evaluated at artificial and natural backgrounds.

Results:

1. One tolerant male form \# 1268 and 6 female forms with weak sensitivity to fungi of Alternaria and Fusarium genus were selected.

2. These forms were used in crossings and $F_{1}$-hybrids have been obtained.

3. $F_{1}$-hybrids were evaluated at artificial and natural infection backgrounds.

4. Analysis the heritability of carrot resistance to fungi of Alternaria and Fusarium genus identified, that carrot resistance to group pathogens didn't inherited by mother's type.

5. Using tolerant carrot line \# 1268 in crossings as the male form and 6 female forms with weak sensitivity to fungi of Alternaria and Fusarium genus increased significantly the percent of tolerant plant in $\mathrm{F}_{1}$-hybrid population evaluated under artificial infection. 


\title{
Study of the role of the MtWOX9-1 gene in somatic embryogenesis
}

\author{
Baltin S.M.*, Tvorogova V.E., Lutova L.A. \\ St. Petersburg State University, St. Petersburg, Russia \\ *email: krubaza@mail.ru
}

Somatic embryogenesis (SE) in plants is the process by which non-zygotic cells form embryos, which go through characteristic stages of embryonic development, ultimately forming a new plant. Many plant species are capable of SE, but in many of them, the formation of somatic embryos requires specific in vitro conditions. SE is widely used for the genetic transformation of plants and for the production of artificial seeds, and the study of its regulators is necessary to improve the methods of obtaining somatic embryos. SE has many similarities with zygotic embryogenesis (ZE): during the somatic embryo development, morphological stages characteristic of ZE can usually be distinguished; moreover, most of the studied $\mathrm{ZE}$ regulators function also during SE. Transcription factors from the WUSCHEL-LIKE HOMEOBOX family (WOX2, WOX8 and WOX9 and others) can be referred to as ZE regulators. Previously in our research, a role of some of their orthologs in the SE in Medicago truncatula was revealed. For example, overexpression of MtWOX9-1 increases SE capacity and changes the level of transcription of many genes. The aim of our study is to further investigate the role of the MtWOX9-1 genes. The main goals include investigating the inactivation of the Medicago truncatula MtWOX9-1 gene using the CRISPR/Cas9 system. At this moment, plants carrying alleles with loss of MtWOX9-1 function have been obtained, and in the future we plan to assess the SE capacity of their offspring.

Acknowledgments: The research was made with support of the Ministry of Science and Higher Education of the Russian Federation in accordance with agreement No. 075-152020-922 date 16.11.2020 on providing a grant in the form of subsidies from the Federal budget of Russian Federation. The grant was provided for state support for the creation and development of a World-class Scientific Center "Agrotechnologies for the Future". 


\title{
Resistance of spring bread wheat lines developed by ARISER to abiotic stress and rust pathogens
}

\author{
Baranova O.A. ${ }^{1 *}$, Sibikeev S.N. ${ }^{2}$, Druzhin A.E. ${ }^{2}$, Gultyaeva E.I. ${ }^{1}$ \\ ${ }^{1}$ All-Russian Institute of Plant Protection (FSBSI VIZR), St. Petersburg-Pushkin, Russia \\ ${ }^{2}$ Agricultural Research Institute of the South-East Region (FSGFSI ARISER), Saratov, Russia \\ * email: baranova_oa@mail.ru
}

In this work, we analyzed 189 spring bread wheat introgression lines developed by ARISER with alien genetic material from different species of the genus Triticum and Aegilops, Agropyron elongatum, Ag. intermedium, Secale cereale, triticale variety Satu. The results of field evaluation in the seasons 2016-2019 characterize the introgression lines taken in the analysis as highly resistant to Saratov populations of leaf rust (Puccinia triticina Erikss.) and stem rust ( $P$. graminis f. sp. tritici). However, out of 158 lines resistant to $P$. graminis in 2016, 65 lines (41.1\%) were resistant in 2020 due to loss of efficacy of Sr25 and Sr6Agi genes in the Volga region. Based on the results of the laboratory evaluation of juvenile resistance, 50 lines highly resistant to stem rust were identified. The resistant lines carried mainly combinations of $S r 31 / L r 26+S r 25 / L r 19$ and Sr31/Lr26+Sr6Agi/Lr6Agi genes, in one line a combination of Sr31/Lr26+Sr25/Lr19+Sr28+Lr10, in one line Sr25/Lr19+Sr22+Lr10 and in one line $S r 31 / L r 26+S r 57 / L r 34+L r 1+L r 3$ genes were identified. The analysis of introgression lines revealed their high genetic diversity for resistance to leaf rust. The following effective $L r$ - genes combinations were identified: $L r 19+L r 26, L r 10+L r 19+L r 26$, Lr19+Lr37, Lr19+Lr26+Lr39, Lr19+Lr6Agi, Lr19+Lr37+Lr6Agi, Lr10+Lr26+Lr6Agi, Lr10+Lr19+Lr39+Lr6Agi, Lr10+Lr39+Lr6Agi and $L r 1+L r 3+L r 34$. The agronomic performance of resistant lines was determined for a set of economically valuable traits such as grain productivity, lodging resistance and flour and bread making quality parameters. The 2018 - 2020 growing seasons were drought seasons, with 2018 and 2019 as hard droughty. Thus, resistant to complex diseases lines were also evaluated for drought tolerance. The wheat lines \# $14=\mathrm{L} 375=\mathrm{L} 505$ /3/Croc/Ae. squ(205)/Weav/4/L505/5/L505 (Lr19/Sr25+Lr26/Sr31+Lr39) and \# $20=$ $=\mathrm{L} 496 / 16$ L505*2/Proc//Bel (Lr6Agi/Sr6Agi+Lr26/Sr31+Sr28+Lr10), exceeding the standard variety Favorit for grain productivity and bread making quality and combined the drought tolerance with high resistance to stem and leaf rusts have been selected. Acknowledgements: The work was supported by RFBR grant No. 18-016-00170 a. 


\title{
Genetics of resistance of spring barley to the agent Ustilago nuda
}

\author{
Bekhtold N.P.*, Orlova E.A. \\ Siberian Research Institute of Plant Production and Breeding - Branch of the Institute of Cytology and \\ Genetics, SB RAS, Novosibirsk, Russia \\ *email: Telichkinanina@mail.ru
}

The emergence and the reproduction of the new races is one of the main reasons for the loss of resistance to smut diseases by the varieties. The trait of the Ustilago nuda resistance is controlled by one, rarely two genes. The efficiency of genes changes over time and depends largely on the racial composition of the pathogen. Known about twenty Run genes, which to control resistance to pathogen. The genes Run 3, 6, 8, 15 are widely used in breeding practice all over the world. In most regions of the Russian Federation are effective highly against the pathogen the genes $R u n 3,6,8,12$. When determining the racial differentiation of the pathogen, the combined analysis system was used on an empirical set of barley and varieties with identified resistance genes. The inoculation of dust smut was used the vacuum method - V.I. Krivchenko. Infection of varieties with identified resistance genes made to identify the most effective resistance genes. Our data carried out about that Run 6 and Run 8 are the effective genes for Ustilago nuda resistance for the forest-steppe of the Ob region. The varieties containing the genes Run 3 + Run 6 (Bonanza, Jet. Morex), Run $3+$ Run 8 (Martoni) and Run $8+$ Run 15 (Suzdalets) are also resistant to the pathogen population. The high breeding value of the genes Run 3 and Run 12 for the conditions of the Novosibirsk region was not confirmed, because varieties Paragon and Galt carrying the Run 3 gene could not always provide protection against the pathogen $U$. nuda. Thus, the damage to the Paragon variety was from weak $(2,6 \%)$ to medium $(19,0 \%)$ annually. The maximum damage to the Galt cultivar over the years of research was $45,7 \%$. For further breeding work, it can be recommended to include in crosses varieties with effective genes for resistance to the local population of the pathogen $U$. nuda, such as Bonanza (Run 3, Run 6), CI 13664 (Run 8), Elf (Run 8), Suzdalets (Run 8, Run 15).

Acknowledgments: This work was supported by the Institute of Cytology and Genetics, SB RAS budget project No. 0259-2021-0018. 


\title{
Development of varieties of spring bread wheat using DH lines in Western Siberia
}

\author{
Belan I.A. ${ }^{1 *}$, Rosseeva L.P. ${ }^{1}$, Blokhina N.P. ${ }^{1}$, Mukhina Y.V. ${ }^{1}$, Trubacheeva N.V. ${ }^{2}$, \\ Pershina L.A. ${ }^{2}$ \\ ${ }^{1}$ Omsk Agricultural Scientific Center, Omsk, Russia \\ ${ }^{2}$ Institute of Cytology and Genetics, SB RAS, Novosibirsk, Russia \\ * email: belan_skg@mail.ru
}

Climate changes, the impact of man-made and anthropogenic factors lead to changes in the growing conditions of crops, which requires the development of high-quality and productive varieties that are adaptive to the growing conditions. As the initial forms for breeding, it is important to use introgression lines, which are carriers of genes that control agronomically valuable traitsWhen using the conventional approach, to stabilize the exhibition of target traits in introgression lines, it is necessary to obtain at least eight self-pollinated generations. So, in bread wheat, it takes from 12 to 15 years to develop a variety using conventional breeding approach. In the laboratory of spring bread wheat of the Omsk Agricultural Scientific Center for the development of varieties of spring bread wheat, along with conventional breeding approach, the use of homozygous DH lines was tested both to accelerate the breeding process and to create promising hybrid combinations with complexes of agronomically valuable traits. Crossing aline DH-17 derived from the alloplasmic recombinant line (H. vulgare) - T. aestivum with alineCom 37-1RS.1BL (CIMMYT) resulted in a hybrid population 311-00-00. Three lines, as a result of breeding trials in different regions, became varieties of spring bread wheat included in the State Register of Breeding Achievements approved for use: Sigma and Uralosibirskaya 2, and the variety Ishimskaya 11 is protected by a patent. The variety Sigma was recommended for cultivation in the 10th regions of the Russian Federation; the variety Uralosibirskaya 2 was recommended in the 9th and 10th regions of the Russian Federation, and from 2021 in the Republic of Kazakhstan.In the Omsk region, the variety Sigma occupies about 50 thousand hectares. The fourth line, was included in the pedigree of the variety Sakmara, which is undergoing State Variety Trial in the Russian Federation. Thus, the four varieties of spring bread wheat have beendeveloped with the participation of the alloplasmic lineDH-17.Another approach was usedwhen including in breeding alloplasmic introgression DH lines DH-48-3 and DH-48-18, which combine resistance genes to powdery mildew, leaf rust, and stem rust. Since 2019 in the nursery of competitive variety trial(CVT). In terms of yield, the lines DH 48-3 and DH 48-18 on average for two years exceeded the standard variety PamyatiAzieva (2.58 t/ha) by more than $3 \mathrm{t} / \mathrm{ha}$, with yields of 6.02 and $6.31 \mathrm{t} / \mathrm{ha}$ respectively. Thus, based on the technology of accelerated breeding using DH lines, it took 6 years to develop the variety. In parallel, using the conventional breeding approaches over the years varieties of spring bread wheat Omskaya 42, Omskaya 44, Omskaya 45 and OmskayaKrepost have been released, each of which took over 10 years to be developed.

Acknowledgments: Some aspects of this work were supported by the RFBR grant No. 20-016-00196. 


\title{
The relationship between root exudation, accumulation of heavy metals and symbiotrophy in peas (Pisum sativum L.)
}

\author{
Belimov A.A.*, Shaposhnikov A.I., Syrova D.S., Guro P.V., Yuzikhin O.S., \\ Azarova T.S., Sazanova A.L., Sekste E.A., Safronova V.I. \\ All-Russia Research Institute for Agricultural Microbiology, St. Petersburg, Russia \\ *email: belimov@rambler.ru
}

After screening of 120 pea genotypes from the N.I. Vavilov Institute of Plant Genetic Resources, ten genotypes contrasting in the accumulation of heavy metals (HMs) such as $\mathrm{Cd}, \mathrm{Co}, \mathrm{Cr}, \mathrm{Cu}, \mathrm{Ni}, \mathrm{Pb}, \mathrm{Sr}$ and $\mathrm{Zn}$ from soil were selected. Inoculation with symbiotic microorganisms reduced HMs contents in these plants. Genotypic differences were revealed in the composition of root exudates (primary and aromatic organic acids, glycosides and amino acids), rhizosphere microbial communities, and mobile forms of HMs or nutrients in the rhizosphere. When dividing pea genotypes into two separate groups with low and high HM content, the components of root exudates determining the differences between them were identified. The highest values of exudation were found for the low-accumulating group. Significant correlations between $\mathrm{HMs}(\mathrm{Ni}, \mathrm{Pb}$, and $\mathrm{Zn})$ content in pea shoots and the intensity of root exudation of some organic compounds were found. However, it was not possible to group the studied genotypes according to the exudation activity into separate clusters. Also, no correlations were found between the intensity of root exudation and the concentration of mobile forms of HMs in the rhizosphere. The results showed that some components of root exudates may play a role in the characterization of plant genotypes in terms of their ability to accumulate HMs. For example, organic acids can chelate metal ions, making them less available for assimilation by the roots. Glycosides can affect the biological activity of rhizosphere processes. Symbiotic parameters (the number and biomass of nodules, nitrogen fixation, formation of mycorrhizal structures, effect of inoculation on nutrient uptake) negatively correlated with the exudation of some components. It is likely that genotypes with low exudation retain more photosyntates for the development of a symbiotic apparatus. The results highlighted the complexity, complexity and interdependence of the observed processes and patterns.

Acknowledgements: The work was supported by the Russian Science Foundation (grant 19-16-00097). 


\title{
The homologue of the agrobacterial gene of cucumopine synthase is expressed in naturally transgenic peanuts
}

\author{
Bemova V.D. ${ }^{1 *}$, Matveeva T.V. ${ }^{2}$ \\ ${ }^{1}$ The N.I. Vavilov All-Russian Institute of Plant Genetic Resources (VIR), St. Petersburg, Russia \\ ${ }^{2}$ St. Petersburg State University, St. Petersburg, Russia \\ * email: viktoria.bemova@yandex.ru
}

Recent studies show that horizontal gene transfer from agrobacteria to plants occurs in evolution with a fairly high frequency: about 7 percent of dicotyledonous plant species are naturally transgeic. They contain homologues of Agrobacterium T-DNA genes in their genomes. The most common of them are opine synthesis genes. In naturally transgenic species Nicotiana tabacum and Cuscuta suaveolens the expression of opine synthase genes was revealed, and opines were identified in plant extracts. Their role in the control of plant-microbial interactions is discussed. The genomes of several species of the genus Arachis, contain homologues of agrobacterial cucumopine synthase (cus) and synthase of deoxyfructosylglutamine (mas2') genes. There are full-length cus genes with intact ORFs in A.duranensis, A. stenosperma, A. hypogaea and A. monticola. However, whether the gene is being expressed has remained to be unknown. Within the framework of this research, the expression of the cus gene in various organs of 9 lines of cultivated peanuts from the VIR collection was investigated. Studied lines have different morphological characteristics and geographic origins. Tissue-specific expression of the cus gene in peanut samples was revealed and lines contrasting in the level of its expression were found. The highest level of expression was observed in the roots. A preliminary assessment of economically valuable traits of peanuts (maturity, yield) when growing plants on nitrogen-rich soils does not show their relationship with the intensity of expression of the cus gene. It seems promising to assess these traits of peanut lines contrasting in expression of cus when cultivated on nitrogen-poor soils.

Acknowledgments: The research was made with support of the Russian Science Foundation grant No. 21-14-00050. 


\title{
Identification and characterization of two novel $V R N-B 3$ alleles in Russian common wheat
}

\author{
Berezhnaya A.A. ${ }^{1,2}$, Kiseleva A.A. ${ }^{2}$, Salina E.A. ${ }^{2}$ \\ ${ }^{1}$ Novosibirsk State University, Novosibirsk, Russia \\ ${ }^{2}$ Institute of Cytology and Genetics, SB RAS, Novosibirsk, Russia \\ * email: al.berezhnayal@gmail.com
}

$V R N-B 3$ wheat gene is one of the key elements of the heading time pathway, the trait that moderates the adaptability of common wheat. Only four alleles for the $V R N-B 3$ gene used to be known before, including the wild type $v r n-B 3$ variant. Our study aimed to find the new $V R N-B 3$ alleles and to investigate their structural and functional characteristics. In this study, 94 common wheat accessions originated in Russia were tested for the allelic diversity of the $V R N-B 3$ gene. We have designed specific primers that covered the promoter region to identify any sequence variations. Those samples that had a different PCR fragment size than known alleles were sequenced. Genotyping results indicated 83 out of 94 winter wheat cultivars had the recessive $v r n-B 1$ allele. The PCR screening also showed the presence of the dominant $V r n-B 3 a$ allele (Kuibyshevskaya-2, Kazachka varieties). Wheat variety Velut has a 1617-bp insertion in the promoter region. Also, ten accessions carried a 160-bp insertion in the promoter region. These alleles were designated as $V r n-B 3 d$ and $V r n-B 3 e$ respectively. The sequence analysis showed the insertion in the Vrn-B3d allele is a retrotransposon and is homologous to the Hordeum vulgare L. LTR retrotransposon (RLX_Hvul_Dacia_RND-1). We used the F2 population from the cross Velut $(V r n-B 3 d) \times$ Tobolskaya $(v r n-B 3)$ to analyze the expression level of the Vrn-B3d allele. F2 hybrids were analyzed using sequence-specific markers and then assembled into two groups (10 plants each). A total RNA was extracted at the two different growth stages 5 leaves unfolded and 1st node. The qPCR experiment did not show a difference in the transcription levels between vrn$B 3 / V r n-B 3 d$ plant groups. Field data indicated the plants carrying the Vrn-B3e allele are associated with later heading time in comparison to the plants with the wild type allele ( $p$-value < 0.05 ).

Acknowledgements: The study was funded by RFBR (No. 20-016-00059). 


\section{Molecular analysis of $\mathrm{BC}_{1} \mathrm{~F}_{1}$ and $\mathrm{BC}_{2} \mathrm{~F}_{1}$ cotton hybrids using SSR markers}

Bobokhujaev Sh. ${ }^{1}$, Abdukarimov Sh. ${ }^{2}$, Sanamyan M. ${ }^{1}$, Makamov A. ${ }^{2}$, Buriev Z. ${ }^{2}$

${ }^{1}$ National University of Uzbekistan named after M. Ulugbek, Tashkent, Uzbekistan

${ }^{2}$ Center for Genomics and Bioinformatics of the AS RUz, Tashkent, Uzbekistan

*email:bobohujayev@mail.ru

In this thesis the molecular analysis of substitution chromosome 4 and 6 in $\mathrm{BC}_{1} \mathrm{~F}_{1}$ and $\mathrm{BC}_{2} \mathrm{~F}_{1}$ generation hybrids is briefly described.

In Uzbekistan, under leadership of Dr. M.F. Sanamyan monosomic lines were created on the basis of L-458 line $(2 n=52)$ based on to $G$. hirsutum L. type of cotton. The monosomic lines were crossed with the line Pima 3-79 of the G. barbadense L., and the $\mathrm{F}_{1}$ generation was obtained. Monosomic hybrids were isolated as a result of cytogenetic analysis of $F_{1}$ hybrids. Molecular analysis using SSR markers was performed to determine which chromosome of $G$. barbadense was substitution into $\mathrm{F}_{1}$ hybrids in the resulting generation.

The backcross offspring were obtained by crossing $F_{1}$ monosomic hybrids with respective monosomic line. Among the backcross hybrids, monosomic plants were isolated as a result of cytogenetic analysis. DNA was isolated from isolated monosomic plants by CTAB (cetyltrimethylammonium bromide) method, and PCR was performed using SSR markers specific to chromosomes 4 and 6.

Results showed that the substitution chromosome 4 in $\mathrm{BC}_{1} \mathrm{~F}_{1}$ (Mo60x( $\mathrm{F}_{1}$ Mo60xPima 379)) and $\mathrm{BC}_{2} \mathrm{~F}_{1}\left(\mathrm{Mo60x}\left(\mathrm{BC}_{1} \mathrm{~F}_{1}\right.\right.$ Mo60xPima 3-79)) and $\mathrm{BC}_{1} \mathrm{~F}_{1}\left(\mathrm{Mo} 75 \mathrm{x}\left(\mathrm{F}_{1}\right.\right.$ Mo75xPima 379) ) and $\mathrm{BC}_{2} \mathrm{~F}_{1}\left(\mathrm{Mo} 75 \mathrm{x}\left(\mathrm{BC}_{1} \mathrm{~F}_{1}\right.\right.$ Mo75xPima 3-79)) were confirmed by five SSR markers such as BNL2572, Gh107, TMB0809, CIR249, JESPR234.

In addition, the substitution of chromosome 6 were confirmed in $\mathrm{BC}_{1} \mathrm{~F}_{1}$ (Mo34xF $F_{1}$ Mo34xPima 3-79), $\quad \mathrm{BC}_{1} \mathrm{~F}_{1} \quad\left(\right.$ Mo92xF $\mathrm{F}_{1}$ Mo92xPima 3-79) and $\mathrm{BC}_{2} \mathrm{~F}_{1}$ (Mo92 $x_{B C} \mathrm{~F}_{1}$ Mo92xPima 3-79) using 11 SSR markers: BNL1440, BNL3650, BNL2884, BNL1064, BNL3359, TMB1277, TMB0154, TMB0853, TMB1538, Gh039, Gh082. 


\title{
Reaction on water stress of the genotypes Hordeum vulgare $L$. at different stages of plant development
}

\author{
Bome N.A. ${ }^{*}{ }^{*}$, Kolokolova N.N. ${ }^{1}$, Tetyannikov N.V. ${ }^{2}$, Weisfeld L.I. ${ }^{3}$ \\ ${ }^{1}$ Tyumen State University, Tyumen, Russia \\ ${ }^{2}$ Federal Scientific Selection and Technology Center for Horticulture and Nursery, Moscow, Russia \\ ${ }^{3}$ Emanuel Institute of Biochemical Physics, Moscow, Russia \\ *email: bomena@mail.ru
}

Phenotyping of drought tolerance in barley was carried out in vivo according to the water-holding capacity of leaves (69 samples) and under conditions simulated with using a 16-percentage of sucrose solution (12 samples). The initial material was characterized by ecological-geographical (16 countries) and genetic (2 subspecies, 21 varieties) diversity. Against the provocative background, there was a lag in the development of shoots and roots, the length of which was $20.9 \%$ (shoots) and $19.0 \%$ (roots) less than in the control. In specimens with a less pronounced stress response (L. AHOR 2542/63, Ethiopia; C.I.10995, Peru), deep roots will allow rational use of the available moisture. Well-developed shoots (Wisconsin x 691-1, USA; Nosovsky 9, Ukraine; Arna, Kazakhstan; Local, Tajikistan; Sonnet, Sverdlovsk region), covering the soil surface, will reduce the evaporation rate. In a field experiment (2018) during the period of heading-flowering ( $0.0 \mathrm{~mm}$ of precipitation; $2.1-4.00$ degrees Celsius above the norm), genotypes are differed in the water-holding capacity of the leaves. Genotypes with high and medium resistance have a significantly larger flag leaf area; chlorophyll content was $36.8-43.8$ units spad. The average yield in the tolerant group was $227.2 \mathrm{~g} / \mathrm{m}^{2}$, in the sensitive it was significantly lower $\left(72.9-186.1 \mathrm{~g} / \mathrm{m}^{2}\right)$. Samples were identified that combine resistance to moisture deficit with high productivity (Kharkovskiy 70, Ukraine; Abyssinian 14, Netherlands; Mutant 4541, Germany). Yield depends to a greater extent on field germination of seeds $(r=0.47)$, productive tillering $(r=0.51)$, grain weight per plant $(r=0.99)$. To select forms that are resistant to water stress, the assessment must be carried out at different stages of plant development, since some genotypes tolerate drought during the germination of seedlings, but are sensitive in the heading phase and vice versa. We consider tolerant samples as promising sources of drought tolerance genes for improving modern barley cultivars. 


\section{Annotation of Siberian larch genome draft assembly}

Bondar E.I. ${ }^{1,2}$, Feranchuk S.I. ${ }^{1}$, Birukhov V.V. ${ }^{1,2}$, Kuzmin D.A. ${ }^{1,3}$, Sharov V.V. ${ }^{1,2,3}$, Oreshkova N.V.., 2, 4 , Krutovsky K.V.1, 5, 6,7

${ }^{1}$ Laboratory of Forest Genomics, Institute of Fundamental Biology and Biotechnology, Siberian Federal University, Krasnoyarsk, Russia

${ }^{2}$ Laboratory of Genomic Research and Biotechnology, Federal Research Center "Krasnoyarsk Science Center," Siberian Branch, Russian Academy of Sciences, Krasnoyarsk, Russia

${ }^{3}$ Department of High Performance Computing, Institute of Space and Information Technologies, Siberian Federal University, Krasnoyarsk, Russia

${ }^{4}$ Laboratory of Forest Genetics and Selection, V. N. Sukachev Institute of Forest, Siberian Branch, Russian Academy of Sciences, Krasnoyarsk, Russia

${ }^{5}$ Department of Forest Genetics and Forest Tree Breeding, Georg-August University of Göttingen, Göttingen, Germany

${ }^{6}$ Laboratory of Population Genetics, N.I. Vavilov Institute of General Genetics, Russian Academy of Sciences, Moscow, Russia

${ }^{7}$ Department of Genomics and Bioinformatics, Institute of Fundamental Biology and Biotechnology, Siberian Federal University, Krasnoyarsk, Russia

*email: bone-post@ya.ru

The main objective of this work was to provide a verified and reliable annotation for the draft genome assembly of Siberian larch, a conifer tree that is known for its frosthardiness, fast growth, and rot-resistant high-quality timber. The MAKER2 annotation pipeline was used for automated gene annotation. The transcriptome assemblies from five tissue types assembled using the TrinityRnaSeq package were used as speciesspecific RNA-seq evidence. RepeatMasker with custom de novo repeat library generated by RepeatModeler was used for masking repeated genomic regions. Gene prediction was done using AUGUSTUS, which was iteratively trained on the verified set of annotated transcripts, preliminarily assembled with TopHat and Cufflinks. Functional annotation was performed using Blast2GO within the OmixBox Platform. Repeating elements comprised $4.8 \mathrm{Gbp}$ or $\sim 39 \%$ of the $12 \mathrm{Gbp}$ genome. In total, 50,163 gene models were obtained consisting of 151,838 exons and 101,675 introns. Repeat content in the intron sequences was lower than in the entire genome, but $12.9 \%$ of introns included transposable elements. GO category assignment based on InterProScan domains identification and BLAST homology search yielded 39253 gene models (77\%) with at least one assigned GO term. 


\title{
The influence of the toxic effect of zinc and mineral starvation on the growth and development of buckwheat regenerants in vitro culture
}

\author{
Borovaya S.A.*, Klykov A.G. \\ Federal Scientific Center of Agricultural Biotechnology in the Far East named after A.K. Chaika, \\ Ussuriysk, Russia \\ * email: borovayasveta@mail.ru
}

Biotechnological methods in breeding are effective in obtaining lines of cultivated plants with improved economically valuable traits and creating completely new genotypes on their basis. Cell-tissue selection, based on the selection of samples that are resistant to a stress factor, take a significant place in solving these problems. The use of heavy metal ions in vitro as selective backgrounds can significantly expand the genetic basis and lead to the emergence common buckwheat forms with new traits and a high potential for resistance to abiotic stressors. The purpose of this work was to study the morphometric traits and adaptive potential of buckwheat regenerant plants of Izumrud and Dikul varieties in vitro culture, resistant to the toxic effect of zinc ions and mineral starvation. The genotypes of common buckwheat: the determinant variety Dikul, selected by the All-Russian Research Institute of Leguminous Crops, and the indeterminate variety Izumrud, selected in the "FSC of Agricultural Biotechnology in the Far East named after A.K. Chaika" were used as source material. The culture was injected with mature seeds, sterilized with concentrated sulfuric acid according to the method of V.A. Tilba, which were then passaged on a hormone-free Murashige and Skoog culture medium (hereinafter MS). To create selective conditions, zinc salt $\left(\mathrm{ZnSO}_{4} \times 7 \mathrm{H}_{2} \mathrm{O}\right)$ was used at concentrations of $808,909,1010,1111,1212$, and $1313 \mathrm{mg} / \mathrm{l}$ in the MS nutrient medium containing $20 \mathrm{~g} / \mathrm{l}$ of sucrose and $6 \mathrm{~g} / \mathrm{l}$ of agar. To simulate mineral starvation, the MC nutrient medium without the addition of macrosalts was used. Induction of direct regeneration of the studied buckwheat genotypes on selective media showed their high tolerance to ionic stress caused by lethal and sublethal doses of $\mathrm{ZnSO}_{4}$. According to the results of 33-day cultivation of test tube microscopes on media with zinc toxicity, 73.8$75.0 \%$ of plants were selected. Secondary cultivation of regenerants under conditions of complete mineral starvation in vitro turned out to be the strongest inhibiting factor for buckwheat. At the same time, a higher level of stress resistance and regeneration capacity was found in the Dikul variety, the morphometric parameters of which were significantly higher than in the Izumrud variety. As a result of the research, the most resistant to the complex stressor buckwheat genotypes were identified. 


\title{
The overexpression of the Arabidopsis $N D B 2$ gene in tobacco plants affects the expression of genes encoding the alternative mitochondrial electron transport pathways and stress proteins
}

\author{
Borovskii G.B. ${ }^{1 *}$, Korotaeva N.E. ${ }^{1}$, Katyshev A.I. ${ }^{1}$, Fedoseeva I.V. ${ }^{1}$, Fedyaeva A.V. ${ }^{1}$, \\ Kondakova M.A. ${ }^{1}$, Rikhvanov E.G. ${ }^{1}$, Shyshlova-Sokolovskaya A.M. ${ }^{2}$, Sauchyn D.G. ${ }^{2}$, \\ Urbanovich O.Yu. ${ }^{2}$ \\ ${ }^{1}$ Siberian Institute of Plant Physiology and Biochemistry, SB RAS, Irkutsk, Russia \\ ${ }^{2}$ Institute of Genetics and Cytology of NAS of Belarus, Minsk, Belarus \\ *email: borovskii@sifibr.irk.ru
}

An important feature of the plant stress response is the activation of alternative pathways of mitochondrial electron transport chain, in particular, rotenone-insensitive NAD(P)Hdehydrogenases. The exact physiological function of its protein family has not been established. It is believed that, together with an alternative oxidase, they participate in the formation of a non-phosphorylating respiratory chain under oxidative stress and suppress the generation of reactive oxygen species. It was proposed that, rotenoneinsensitive $\mathrm{NAD}(\mathrm{P}) \mathrm{H}$-dehydrogenases, together with the alternative oxidase, participate in formation of a non-phosphorylating electron transport chain in response to oxidative stress and suppress the reactive oxygen species generation. An alternative hypothesis suggests that its proteins are important sources of ROS generation. It is assumed that the enzyme of "external" non-phosphorylating NADH dehydrogenase (NDB2) affects the mitochondrial functioning, expression of stress response genes, and stress signaling program of by changing the ROS amount. The genetically modified Nicotiana tabacum plants expressing NDB2 from Arabidopsis thaliana were obtained to elucidate the role of its protein in the plant resistance mechanisms. In the leaves of T4 plants, $n d b 2$ expression and accumulation of the A. thaliana NDB2 protein were shown. AtNDB2 expression and accumulation and of corresponding protein and its localization in tobacco mitochondria were shown. AtNDB2 overexpression changes the expression of tobacco genes involved in alternative electron transport pathways, affects the stress proteins content, comparative rate of ROS generation and the level of TBA-reactive products in tobacco leaves. It can be assumed that AtNDB2 influences the stress response, the development of oxidative stress, and tobacco tolerance to low temperatures. 


\title{
Screening collection varieties of VIR for resistance to stress factors (resistance to diseases and lodging) at Novosibirsk region
}

\author{
Boyko N.I. ${ }^{1 *}$, Aparina V.A. ${ }^{1}$, Sukhomlinov V.Yu. ${ }^{1}$, Zuev E.V. ${ }^{2}$, Piskarev V.V. ${ }^{1}$ \\ ${ }^{1}$ Siberian Research Institute of Plant Production and Breeding - Branch of the Institute of Cytology \\ and Genetics, SB RAS, Novosibirsk, Russia \\ ${ }^{2}$ Federal Research Centre the N.I. Vavilov All-Russian Institute of Plant Genetic Resources, \\ St. Petersburg, Russia \\ * email:n.bojko@mail.ru
}

Collection varieties of spring soft wheat (Triticum aestivum L.) from The N.I. Vavilov All-Russian Institute of Plant Genetic Resources was studied in Siberian Research Institute of Plant Production and Breeding - Branch of the Institute of Cytology and Genetics, SB RAS. Fifty new varieties are received annually. They are sown manually in the first year, then, the varieties are studied on plot $\left(2 \mathrm{~m}^{2}\right)$ for three years. The collection of varieties is compared with the standards: Novosibirskaya 15 (early ripeness), Novosibirskaya 31 (mid-early ripeness), Obskaya 2 (mid ripeness), Sibirskaya 17 (mid-late ripeness). The appropriation of the varieties to the ripeness group carried out in the first year of sowing. The field assessment for resistance to biotic factors (Blumeria graminis and Puccinia triticina) carried out using the VIR method under natural infection conditions. The weather conditions of 2018-2019 were favorable for the development of powdery mildew and leaf rust. During the period 2018-2019 years 161 varieties were studied, 21 from which characterized by resistance to leaf rust and 7 to powdery mildew for 2 years. Varieties Sparrow (K-66090) and LD25 (Saratov Research Institute South-East) were not affected by leaf rust and powdery mildew (score - 99). Lodging rating of varieties from this collection were studied. The evaluation indicated that $39.8 \%$ (64 varieties) were characterized by very high resistance to lodging (score - 9), variety NIL Thatcher Lr45 (66210) was not resistance to lodging (score 3 and 5). At the same time, the maximum yield $\left(629.3 \mathrm{~g} / \mathrm{m}^{2}\right)$ in 2018 was formed by the variety Sigma 2 (k-65999), which was characterized by high resistance to leaf rust (score 7 ), powdery mildew (score 99) and resistance to lodging (score 9). The maximum yield $\left(620.8 \mathrm{~g} / \mathrm{m}^{2}\right)$ in 2019 was formed by the variety M83-1591 (66234), which was characterized by medium resistance to leaf rust (score 5), medium and high resistance to powdery mildew (score $5 ; 7$ ) and medium and high resistance to lodging (score $5 ; 7$ ). Acknowledgements: This work was supported by ICG SB RAS budget project No. 0259-2021-0018. 


\section{Hyssopus officinalis L. genetic similarity in vitro}

Bulavin I.V.*, Ivanova N.N., Mitrofanova I.V.

The Labour Red Banner Order Nikita Botanical Gardens - National Scientific Center of the RAS, Yalta, Russia

*email: labgennbs@yandex.ru

Hyssopus L. is a small Mediterranean genus of perennial undershrubs are used as aromatic, medicinal and ornamental plants. Traditionally, hyssop plants are propagated by seeds, however this method has some limitation for perspective forms and cultivars. Nowadays, biotechnological methods are important for mass multiplication and conservation of obtained valuable breeding forms. The growth regulator effects on the plant material regeneration in vitro, especially on genetic stability follow widely discuss. The objective of our investigation was to obtain direct in vitro plant regeneration and analyzing the genetic stability of hyssop plants in vitro. Hyssopus officinalis cv. Nikitskiy Beliy ex situ was used. Multiplication from single-node segments of shoot/microshoot on modified MS culture medium with half-strength of basal salts, vitamins, $0.5 \mathrm{mg} / \mathrm{L} \mathrm{BAP}$ and $0.1 \mathrm{mg} / \mathrm{L}$ IBA was carried out. Plant regeneration from leaf discs on the same medium without BAP and IBA, but with $0.8-1.5 \mathrm{mg} / \mathrm{L}$ TDZ was obtained. DNAs from leaves of ex situ and in vitro plants using CTAB-method with $2 \%$ PVP were isolated. RAPD-PCR had been performed with BioMaster HS-Taq PCR-Sp $(2 \times)$ (Biolabmix, RF), OPA1-10 primers ( 40 cycles, annealing $\left.-36^{\circ} \mathrm{C}\right)$. The amplified fragments were analyzed by electrophoresis in $1.7 \%$ agarose gel with $0.5 \times \mathrm{TBE}$ buffer at $85 \mathrm{~V}$ during $1 \mathrm{~h}$ using universal power supply PowerPac ${ }^{\mathrm{TM}}$ (BioRad, Singapore). The agarose gel was imaged with E-box documentation system (Vilber Lourmat, France) and analyzed using Image Lab ${ }^{\mathrm{TM}}$ Software Version 6.0 (Bio-Rad, USA). The experiment was repeated twice and reproducible bands were analyzed. Investigation of plant genetic similarity between ex situ plants and in vitro regenerants was done. All investigated primers gave reproducible bands were monomorphic and no polymorphism was detected. Thus, developed method of Hyssopus officinalis cv. Nikitskiy Beliy direct regeneration in vitro gave microshoots/clones with normal morphology, genetically identical to mother plants ex situ that is very important for the future mass plant multiplication of valuable genotypes and breeding forms.

Acknowledgments: Supported by the ST No. 0829-2019-0038. 


\title{
Endophytic bacteria of the Bacillus induce resistance of potato plants to viruses
}

\author{
Burkhanova G.*, Sorokan A., Cherepanova E., Maksimov I. \\ Institute of Biochemistry and Genetics - Subdivision of the Ufa Federal Research Centre of the Russian \\ Academy of Sciences, Ufa, Russia \\ *email: guzel_mur@mail.ru
}

Inheritance of potato resistance to viruses can be determined by the activity of protective proteins and enzymes involved in nonspecific mechanisms of plant resistance, such as ribonuclease (RNase). In our work, it was shown that in potato plants treated with bacterial cell suspensions of the $B$. subtilis 26D and B. thuringiensis B-6066 strains, the RNase activity significantly increased and the viral RNA content decreased upon infection with PVX viruses. The same effect was observed when plants were treated with the $B$. subtilis TS2 separately and together with $B$. thuringiensis B-5351 against PVS; and bacterial strains B. subtilis TS2, B. subtilis 26D and B. subtilis Tt12 against PVY; $B$. thuringiensis $\mathrm{B}-5351$ against $\mathrm{M}$. Thus, the activation of RNases induced by inoculation with endophytes is virus-specific. Treatment of potato plants with B. thuringiensis B-6066 bacteria increased the expression of the PR1, PR4 genes; B. subtilis TS2 - PR1, PR4; B. thuringiensis B-5351 and B. subtilis STl-7 - PR1, PR4, PR6, PR10; B. subtilis TS2 and B. subtilis 26D - PR1, PR4, PR6, PR9, PR10, when infected with viruses. Co-inoculation of plants with a preparation of a combination of bacteria $B$. thuringiensis B-5351 and B. subtilis TS2 and B. thuringiensis B-5351 and $B$. subtilis $26 \mathrm{D}$ led to a significant increase in the level of expression of all studied genes upon infection with the PVS or PVM virus compared to the control. The combination of different endophytic bacterial strains can promote activation of resistance reactions in potato plants. Thus, these bacterial strains, which have high RNase activity, activate plant RNases and expression PR-proteins, leads to the development of plant induced systemic resistance and can be proposed for creating new microbiological compositions for combating viral plant infections.

Acknowledgments: The work is supported by Department of science and technology (DST) of the Government of India No. 19-46-02004. 


\title{
Effect of melatonin deficiency and disruption of its receptor signaling pathway on photosynthetic parameters and expression of chloroplast genes in plants of Arabidopsis thaliana under photooxidative stress
}

\author{
Bychkov I.A.*, Kudryakova N.V., Kusnetsov V.V. \\ K.A. Timiryazev Institute of Plant Physiology RAS, Moscow, Russia \\ *email:Ivan.a.b@mail.ru
}

Melatonin is a highly active biological substance with the well known antioxidant function in plants. However, its activity as a regulator of physiological processes is still of the great interest. The aim of this work was to study the regulatory role of melatonin under photooxidative stress in wild-type Arabidopsis, ecotype Columbia-0, and the mutants for melatonin synthesis (asmt) and signaling (cand2 and gpal). The two-weeksold plants were treated with $50 \mu \mathrm{M}$ of melatonin for three days and subjected to photostress $\left(600 \mu \mathrm{E} \mathrm{m}^{-2} \mathrm{~s}^{-1}\right)$ for 24 hours. Exposure of wild-type control plants to high light negatively affected the content of photosynthetic pigments, impaired the functioning of the reaction centers of photosystem II, and caused a decrease in the expression of photosynthetic genes and the content of endogenous melatonin. However, exogenous melatonin significantly reduced the damaging effect of light stress, as could be judged by physiological parameters, and maintained the expression of photosynthesis genes. A possible mechanism for maintaining the activity of chloroplast genes may be associated with the up regulation of the genes for chloroplast transcription apparatus since melatonin activated genes for plastid-encoded RNA polymerase and chloroplast nuclear-encoded RNA polymerase. The asmt mutant exhibited a reduced level of endogenous melatonin, much severe suppression of photosynthesis, and a greater sensitivity to exogenous melatonin. The cand2 and gpal mutants were insensitive to melatonin treatment: with the response to stress similar to that of Col-0, melatonin had no effect on physiological parameters, the expression of the some genes for transcription apparatus and photosynthetic genes. Thus, under conditions of photooxidative stress melatonin can act not only as an antioxidant, but also as a hormone-like substance, able to regulate the expression of chloroplast genes through the activity transcription apparatus. The data obtained confirms the role of CAND2 as a putative melatonin receptor. 


\title{
Plant genetic resources for improving stress tolerance - examples for cereals
}

\author{
Börner A. \\ Leibniz. Institute of Plant Genetics and Crop Plant Research (IPK), Gatersleben, Germany \\ email:boerner@ipk-gatersleben.de
}

Plant genetic resources for food and agriculture (PGRFA) play a major role for global food security. The most significant and widespread mean of conserving PGRFA is ex situ conservation. World-wide 7.4 million accessions are stored in about 1,750 ex situ genebanks. Plant ex situ genebank collections comprise seed genebanks, field genebanks as well as in vitro and cryo collections. Species whose seed can be dried, without damage, down to low moisture contents can be conserved in specially designed cold stores. Such "orthodox" seeds can be expected to maintain a high level of vigour and viability for decades. Field genebanks, in vitro and cryo storage are used primarily for species which are either vegetatively propagated or which have non-orthodox seeds that cannot be dried and stored for long periods. With a total inventory of 150,000 accessions from 3,212 plant species and 776 genera, the 'Federal ex situ Genebank of Germany' in Gatersleben holds one of the most comprehensive collections worldwide. It comprises wild and primitive forms, landraces as well as old and more recent cultivars of mainly cereals but also other crops. Starting in the 1920's material was accumulated systematically. Seed storage is managed in large cold chambers at $-18^{\circ} \mathrm{C}$. Seeds are kept in glass jars, covered with bags containing silica gel (active collection) and in aluminum bags under vacuum (base collection). The maintenance of the collection requires regeneration. Each year between 8 and 10 Thousand accessions are grown either in the field or in glasshouses. The collection has been widely characterized and evaluated. In the cereals, mainly wheat and barley, a number of bi-parental mapping populations and association mapping panels have been established to allow for the genetic analysis of various traits. The current focus covers resistance/tolerance to a number of biotic and abiotic stresses, in particular drought. 


\section{Tomato endophytic bacteria bioactive compounds as potential agents for the postharvest biocontrol of gray mold disease}

Chaouachi M. ${ }^{1,2,3}$, Marzouk T. ${ }^{1,2}$, Jallouli S. ${ }^{2}$, Elkahoui S. ${ }^{2,4}$, Gentzbittel L. ${ }^{3,5}$, Djébali N. ${ }^{2}$, Ben C. ${ }^{3,5 *}$

${ }^{1}$ Univ. of Tunis El Manar, Tunis, Tunisia

${ }^{2}$ Lab. of Bioactive Substances, Centre of Biotech. of Borj Cedria, Tunisia

${ }^{3}$ Lab. of Functional Ecology \& Environment, CNRS, Univ. of Toulouse, France

${ }^{4}$ Dept of Biol., College of Sciences, Univ. of Ha'il, Saudi Arabia

${ }^{5}$ Digital Agriculture Lab., Skolkovo Institute of Science and Technology, Moscow Region, Russian

Federation

*email:C.Ben@skoltech.ru

Botrytis cinerea is one of the most harmful postharvest fungal pathogens causing significant losses in fresh fruits and vegetables. Safer alternatives to hazardous synthetic fungicides are sought to control postharvest decay loss. The use of antagonistic microorganisms is increasingly popular worldwide. We investigated the antifungal and plant growth promoting activities and the identity of volatile organic compounds (VOCs) produced by tomato-derived endophytic bacteria strains. The capacity of selected strains to prevent postharvest $B$. cinerea infection on tomatoes through VOCs and soluble compounds was studied. A collection of 50 endophytic bacterial strains was established from various organs of tomato plants from Cape Bon (Tunisia). Endophytic bacteria from tomato healthy plants mainly colonize leaves and are significantly enriched in Bacillus strains. In vitro assays showed that $36 \%$ of the strains produce antifungal VOCs against $B$. cinerea and about $14 \%$ produce VOCs with specific promoting effects on tomato seedling length or biomass production. Five strains with fungal antagonistic effect were selected for further analysis. They produced a core set of 7 VOCs along with different strain-specific and known antifungal VOCs. Bio-protection assay on tomato fruits showed that the Enterobacter strain TR1 produces the most protective VOCs against B. cinerea infection with 3-Methylbutan-1-ol as a major volatile compound which totally suppressed $B$. cinerea growth. In contrast, the Bacillus strains showed better protection against fungal infection when applied as vegetative cells. These results support the use of the selected endophytic bacteria strains as potential biocontrol agents to reduce postharvest decay of $B$. cinerea, as well as 3-Methylbutan-1-ol as promising antifungal volatile to apply during postharvest commercialization of tomatoes. 


\section{Role of GATA-family transcription factors in the regulation of chlorophyll biosynthesis in green unicellular algae Chlamydomonas reinhardtii}

Chekunova E.M.*, Solodyankin P.A.

Department of Genetics and Biotechnology of Saint-Petersburg State University, St. Petersburg, Russia

*email: elena_chekunova@mail.ru

The adaptation of photosynthetic cells to light mostly based on the expression regulation of genes that control both the metabolism of chloroplast pigments - chlorophylls (CHLs) and carotenoids, as well as the structural organization of the cell. The aim of our work is to investigate the genetic mechanisms of transcriptional regulation of the CHLs biosynthesis in heterotrophic growth conditions and during adaptation to the light of Chlamydomonas $(C$.) reinhardtii cells. Unlike higher plants, unicellular green algae $C$. reinhardtii are able to synthesize CHLs not only in the light, but also in the dark, which allows to study the genetic control of the dark chlorophyll biosynthesis. Until recently, it was believed that the ability of plants and phototrophic microorganisms to synthesize CHLs in the light and in the dark depends only on the presence of two enzymes that converted of protochlorophyllide (Phld) to chlorophyllide (Chld) in the pigment biosynthesis chain. Light-dependent catalysis is carried out by Phld-oxidoreductase (POR), and the dark reaction are provided by dPOR enzyme, encoded by chloroplast genes, originating from eubacterial nitrogenases. In evolution, the angiosperms lost their $\mathrm{dPOR}$, and ancient forms, including algae, retained this enzyme. The study of chlorophyll-less in the dark and light-greening C. reinhardtii mutants on the LTS3 gene allowed us to assume the existence of other ways to regulate the CHLs biosynthesis. We showed that the LTS3 gene encoded the GATA-transcription factors (TF), which, under heterotrophic conditions activates the expression of genes encoding magnesium chelatase enzyme. Little is known about the functioning of GATA-TF in green algae. Recently, their role in the control of development and nitrogen metabolism was shown in higher plants. In addition to LTS3, in the genome of $C$. reinhardtii, we found six more genes encoding GATA-TF factors. To study their role in the adaptation of algal cells to light, we chose the Targeted Insertional Mutagenesis method based on the CRISPR/Cas system. 


\title{
Site-directed mutagenesis of maize elite germplasm through pollination by cas9/gRNA-transgenic, haploidy-inducing lines
}

\author{
Daghma D.E.S.*, Mirzakhmedov M., Chamas S., Büchner H., Satpathy P., \\ Kumlehn J. \\ Leibniz. Institute of Plant Genetics and Crop Plant Research (IPK), Plant Reproductive Biology, \\ Gatersleben, Germany \\ *email:daghma@ipk-gatersleben.de
}

To fully exploit the immense potential of genome editing for plant breeding, it is necessary to induce target sequence-specific modifications directly using elite germplasm. With this goal in mind, we are pursuing a new strategy based on the utilization of haploidy-inducing maize lines. Such lines need to be transformed with cas 9 and guide (g)RNA expression units and then used as pollinators. Upon fertilization, the target motif in the hybrid zygote's maternal genome may be processed by the transgene products introduced from the sperm cell, whereas the transgene-bearing pollinator genome is being eliminated during early embryogenesis. Our concept further involves that the egg cell-derived genome remaining in the haploid embryo, including any Cas endonuclease-induced modification, can be identically duplicated by colchicine treatment. Outcome of this procedure will be progeny with edits in homozygous condition in the genetic background of the mother plant, while carrying neither portions of the haploidy-inducing pollinator line nor Cas9 and gRNA encoding transgenes. The possibility of directly editing elite lines that have hitherto not been amenable to transformation arises from the fact that haploidy-inducing lines can be utilized to pollinate virtually any maize accession of choice. However, the difficulty to transform available haploidy inducer lines, prompted us to generate new such lines via Cas9mediated knockout of the PHOSPHOLIPASE Al (PLA1/MTL/NLD) gene, which is known to confer haploid-inducing ability to maize. Accordingly, two transformation vectors carrying three $P L A l$-specific gRNAs were first functionally validated via PEGmediated transfection of maize protoplasts. Subsequently, Agrobacterium-mediated transformation of Hi-II maize was conducted. The analysis of the target motifs in primary transgenic plants revealed that 23 out of 24 and 26 out of 28 plants carried mutations in target motifs 1 and 3 respectively. The selection of homozygous mutants among progeny, their test for haploidy-inducing capability and retransformation with cas $9 / \mathrm{gRNA}$ constructs addressing diverse target genes of interest is in progress. 


\title{
Creation of common wheat lines with pyramids of genes for resistance to leaf rust
}

\author{
Davoyan E.R., Bespalova L.A., Agaeva E.V., Davoyan R.O., Khudokormova J.N., \\ Zubanova Yu.S., Mikov D.S., Boldakov D.M. \\ National Center of Grain named after P.P. Lukyanenko, Krasnodar, Russia \\ *email:davayan@rambler.ru
}

The purpose of this work was to transfer to leaf rust (Puccinia triticina Erikss.) resistance genes $\operatorname{Lr} 9, \operatorname{Lr} 19, \operatorname{Lr} 24$, and $\operatorname{Lr} 37$ into common wheat cultivars and the creation of genotypes with the pyramids of these genes using DNA-markers. Isogenic lines of the Tchatcer cultivar were used as donors, and the highly productive cultivars Grom and Tanya, susceptible to leaf rust, were used as recipients. Plants from $F_{1}$ with DNAmarkers linked to the desired $L r$-genes were selected for backcrossing and combining several $L r$-genes in one genotype. Genotypes with combinations of the transmitted genes were identified at each subsequent stage. All plants from $\mathrm{BC}_{3} \mathrm{~F}_{3}$ were evaluated on disease resistance in the field and laboratory conditions and its phenotype, productivity and grain quality traits. Fifty-six lines were obtained with combinations of genes $L r 9+L r 19, L r 9+L r 37, L r 19+L r 24, L r 19+L r 37, L r 24+L r 37$ as a result of the work carried out in $\mathrm{BC}_{3} \mathrm{~F}_{7}$. Seven lines with a combination of genes $\operatorname{Lr} 9+\operatorname{Lr} 19+\operatorname{Lr} 37$ and one with a combination of genes $L r 9+L r 24+L r 37$ were selected. All selected lines were resistant to leaf rust and powdery mildew. In terms of protein and gluten content, most of the lines exceeded those of the standard cultivar Grom. At the same time, many of them were characterized by a significant decrease in productivity in comparison with the recipient cultivars. The most perspective lines were selected for further study in competitive cultivar testing. Line L.17-11Ms35-2 with a combination of genes $L r 9+L r 19$ has a high productivity of $0,9 \mathrm{~kg} / \mathrm{m}^{2}$, good values of protein and gluten content of 15,2 and $27,6 \%$ respectively. Lines L.208-17Ms7, L.208-17Ms8 with a combination of genes $L r 24+L r 37$ have high frost resistance, protein and gluten content at the level of cultivars Grom and Tanya. A semi-dwarf (plant height $82 \mathrm{~cm}$ ) line L.156-16Ms4 with a pyramid of genes $\operatorname{Lr} 9+\operatorname{Lr} 24+\operatorname{Lr} 37$ with high frost resistance and good productivity potential was isolated. 


\title{
Using synthetic forms of RS5 and RS7 to expand the genetic diversity of common wheat for disease resistance
}

\author{
Davoyan R.O. ${ }^{1}$, Bebykina I.V. ${ }^{1}$, Davoyan E.R. ${ }^{1}$, Zubanova Y.S. ${ }^{1}$, Zinchenco A.N. ${ }^{1}$, \\ Badaeva E.D. ${ }^{2}$, Salina E.A. ${ }^{3}$, Adonina I.G. ${ }^{3}$ \\ ${ }^{1}$ National Center of Grain named after P.P. Lukyanenko, Krasnodar, Russia \\ ${ }^{2}$ Vavilov Institute of General Genetics, Russian Academy of Sciences, Moscow, Russia \\ ${ }^{3}$ Institute of Cytology and Genetics, SB RAS, Novosibirsk, Russia \\ * email:davoyanro@mail.ru
}

Synthetic recombination forms RS5 (BBAASD') and RS7 (BBAASU) was obtained from crossing genome substitution form Avrodes (BBAASS) with synthetics T. durum/Ae. tauschii (BBAAD'D ${ }^{t}$ ) and Avrolata (BBAAUU). Resistant to leaf rust, yellow rust and powdery mildew introgression lines have been obtained from backcrosses RS5 and RS7 with the susceptible varieties of common wheat Krasnodarskaya 99 and Rostislav. DNA-analysis of 24 leaf rust resistant lines was carried out for the presence of known effective genes previously identified in synthetic forms: Lr28, Lr35 and Lr51 from Ae. speltoides; Lr9 from Ae. umbellulata and Lr39 from Ae. tauschii. Only one line obtained with the participation of the RS7 synthetic showed presence of the gene Lr28. The cytological study (C-banding and FISH) of the lines obtained using the RS7 form revealed new translocations of T1DS.1DL-1SL, T3DS.3DL-3SL and the substituted chromosome 7D(7S) from Ae. speltoides. New translocations T2DS.2DL-2UL and T7DL.7DS-7US also have been identified from Ae. umbellulata. The new substitutions $4 \mathrm{D}\left(4 \mathrm{D}^{t}\right), 6 \mathrm{D}\left(\mathrm{D}^{\mathrm{t}}\right)$ from Ae. tauschii and $7 \mathrm{D}(7 \mathrm{~S})$ from Ae. speltoides were determined for the first time in the lines obtained from synthetic RS5. Lines with genetic material from two wild species at once were revealed. In the line 3379n14, translocations in chromosomes 5BL, 1DL, 2DL from Ae. speltoides and 7DS from Ae. umbellulata were identified. Line 4626p16 presumably has a 2DS.2DL2UL translocation from Ae. umbellulata and T7SS.7SL-7DL from Ae. speltoides. In the line 4991p17, substituted chromosomes 6D(D) from Ae. tauschii and 7D(7S) from Ae. speltoides were obtained. Presumably, lines with new translocations and substituted chromosomes may carry previously unidentified genes for resistance to fungal diseases, in particular to leaf rust, from the species Ae. speltoides, Ae. umbellulata and Ae. tauschii. 


\title{
Effect of allelic forms of GRFs genes on the development of common wheat under different conditions of nitrogen supplementation
}

\author{
Divashuk M.G.*, Litvinov D.Y., Chernook A.G., Karlov G.I., Bazhenov M.S. \\ All-Russia Research Institute Of Agricultural Biotechnology, Moscow, Russia \\ * email:divashuk@gmail.com
}

Nitrogen fertilizers increase the yield of cereals, but at the same time they increase the height of the plants and make the plants susceptible to lodging. To improve resistance to lodging, "dwarfing" genes are employed, however in addition to reducing plant height, these genes reduce the response to nitrogen fertilization and worsen some economically valuable traits, for example, reduce the size of the grain. GRFs (Growth-regulating factors) are a family of genes that encode transcription factors that regulate plant growth and development, organ and tissue formation, and plant response to stress. By inhibiting or overexpressing certain $G R F s$ in rice, it was possible to alter plant height and grain size. Also, GRF4 improves the efficiency of using nitrogen fertilizers in rice. We suggest that by choosing certain allelic variants of GRFs and their combinations with $R h t$ "dwarfing" genes, the use of nitrogen fertilizers can be significantly improved, as well as some of the agronomic characteristics of existing wheat varieties. To identify the $G R F$ alleles that give wheat the desired characteristics, we sequenced several GRFs, developed markers and performed genotyping of a collection of more than 250 Russian common wheat cultivars and found a great allelic diversity of these genes. Then, we performed digital phenotyping of a number of common wheat lines in which GRFs and $R h t$ genes were simultaneously genotyped. Plants were grown indoors under various conditions of nitrogen supply, and their main morphological (height, foliage area, digital biomass, etc.) and spectral (NDVI, etc.) characteristics were non-invasively measured during the first months of development using TraitFinder phenotyping system (Phenospex, Netherlands). The revealed associations between certain combinations of GRFs and $R h t$ genes indicate good prospects for wheat breeding based on specific GRF alleles for the development of new semi-dwarf wheat varieties with improved nitrogen utilization.

Funding: Kurchatov Genomic Center of All-Russia Research Institute of Agricultural Biotechnology, agreement No. 075-15-2019-1667. 


\section{Structural and functional characterization of transcription factor binding sites: from bioinformatics to hormone biosensors}

Dolgikh V. ${ }^{1}$, Levitsky V. ${ }^{1,2}$, Oshchepkov D. ${ }^{1}$, Zemlyanskaya E. ${ }^{1,2 *}$

${ }^{1}$ Institute of Cytology and Genetics, SB RAS, Novosibirsk, Russia

${ }^{2}$ Novosibirsk State University, Novosibirsk, Russia

*email: ezemlyanskaya@bionet.nsc.ru

ETHYLENE INSENSITIVE 3 (EIN3) transcription factor is the master regulator of gene expression in response to plant hormone ethylene. It binds a short nucleotide sequence referred to as EBS to induce transcription. Arabidopsis thaliana reporter EBS:GUS driven by such EIN3 binding site is widely used as a sensor for detection of ethylene signaling. However, the role of EBS arrangement (syntax) in EIN3 functioning was not investigated so far. Here we accomplish a systematic bioinformatics analysis of EIN3 bound sequences in Arabidopsis genome to shed light on molecular mechanisms utilized for regulation of transcriptional response to ethylene in plants.

Integarating publicly available ChIP-seq and DAP-seq data on EIN3 binding with RNAseq data on ethylene-induced transcriptomes in Arabidopsis seedlings we discovered a previously unknown EBS architecture that is enriched in EIN3 bound sequences to a much greater extent than a single EBS motif. This new configuration is a head-to-head inverted repeat of EBS-like sequences with 1 bp overlap referred to as $2 \mathrm{EBS}(-1)$. We also demonstrated that the inverted repeat of the coreEBS with the overlap of the motifs but not with a spacer is enriched in the Arabidopsis genome. Based on these findings we consider that 2EBS(-1) is a canonical EIN3 binding site in A. thailana genome. We further showed that of all EBS configurations under study only 2EBS(-1) was significantly associated with transcriptional response of EIN3 targets to ethylene treatment. Moreover, it tended to cause a more pronounced transcriptional response than other EBS configurations. We used these findings to design a new genetic sensor for highly sensitive detection of ethylene signaling. Taken together, this work provides new insight on the molecular mechanisms utilized for regulation of transcriptional response to ethylene in plants.

Acknowledgments: This work was supported by the RSF grant No. 20-14-00140. 


\title{
Involvement of the red light receptors phytochrome A and phytochrome $B$ in the regulation of gene expression of the plastid transcription apparatus by cytokinin during de-etiolation of $A$. thaliana
}

\author{
Doroshenko A.S. ${ }^{1 *}$, Malyukova A.M. ${ }^{1,2}$, Danilova M.N. ${ }^{1}$ \\ ${ }^{1}$ Timiryazev Institute of Plant Physiology, RAS, Moscow, Russia \\ ${ }^{2}$ Moscow State University, Moscow, Russia \\ * email: anastasiya04101993@gmail.com
}

The development of chloroplast from etioplast during de-etiolation is based on a lightdependent change in the expression of the plastid and nuclear genomes. Activation of plastid gene transcription is caused by the complication of the plastid transcription apparatus (PTA). In etioplasts, the monosubunit RNA-polymerase NEP, which is represented by two enzymes RPOTp and RPOTmp, exhibits a greater transcriptional activity, while the multisubunit RNA-polymerase PEP, represented by the core subunits and sigma-factor, has a lower transcriptional activity. Under white light PEP is activated due to association with PAP proteins. In addition to light, phytohormones also affect the architecture of PTA during the de-etiolation. In particular, cytokinins stimulate the accumulation of transcripts of some PTA genes under white light, but the molecular mechanism is not completely known. We suggested that the positive effect of cytokinin on the expression of PTA genes may be mediated by the red light receptors phytochromes. Using PCR after reverse transcription, we investigated the regulation of the expression of PTA genes by red light and cytokinin in wild type Landsberg erecta (Ler) and mutant phyAphyB seedlings. Compared to the white light, red-light caused a smaller increase in the mRNA level of some PTA genes in Ler. Cytokinin stimulated the growth of mRNA level of some PTA genes under both white and red light, however under red light a weaker response was observed. In contrast to Ler, white and red-light exposure of phyAphyB resulted in a smaller rise of transcripts level of some PTA genes. Cytokinin treatment of phyAphyB under both red and white light stimulated the accumulation of transcripts of some PTA genes, however their level was lower than in Ler. These results indicate the involvement of phytochrome A and B in cytokinindependent de-etiolation of A.thaliana.

Acknowledgments: This research is supported by the RFBR (grants No. 19-34-90183 and No. 20-04-00294A). 


\title{
DNA-technologies in rice breeding for resistance to bio- and abiotic stressors
}

\author{
Dubina E.V.*, Ruban M.G., Garkusha S.V., Lesnyak S.A. \\ Federal Scientific Rice Centre, Krasnodar, Belozerny, Russia \\ *email: lenakrug1@ rambler.ru
}

According to the degree of harmfulness for rice, blast (the causative agent - fungus Pyricularia oryzae Cav.) takes the first place. Weeds compete with crops for light, mineral nutrition and space. In the system of plant protection against diseases, the most effective and environmentally friendly method is development of "immune" rice varieties with genes for resistance to blast infection $\mathrm{Pi}$, and in the fight against weeds varieties with genes for tolerance to prolonged immersion of plants under water (Sub1), as a factor of controlling weeds, and their rapid introduction into production.

Based on the use of modern technologies of molecular DNA marking, we introduced and pyramided the genes for blast resistance Pi-ta, Pi-b, Pi-1, Pi-2, Pi-33 and tolerance to prolonged flooding Sub1 A in domestic rice varieties to give them long-term resistance and tolerance to these stressors.

As a result of a number of backcrosses, breeding material with introduced and pyramided genes for blast resistance and tolerance to prolonged flooding was obtained. The control of dominant alleles of target genes during the breeding process was carried out using molecular labeling methods.

The phytopathological evaluation of the obtained lines showed their resistance to M. grisea. Rice varieties Allians, Lenaris with the Pi-ta gene were released in 2019 and 2020 respectively, rice varieties Utes with the Pi-2 gene and Voskhod (Pi-2, Pi-33), adapted to growing conditions in the south of Russia, resistant to the Krasnodar population of the pathogen, as well as having high yield and quality, were submitted for State variety testing in 2020. Phenological assessment of resistance to prolonged submergence of rice breeding samples with a complex of Pi and Sub1A genes made it possible to select forms that are tolerant to this stressor.

The introduction and cultivation of such varieties in production will make it possible to reduce the use of chemical means of protection, to obtain environmentally friendly agricultural products and to avoid pollution of grain ecosystems. 


\title{
Informative SSR markers for genotyping and intervarietal differentiation of cultivated oat
}

\author{
Dubovets N.I.*, Sycheva E.A., Sokolyuk A.V., Bondarevich E.B., Solovey L.A. \\ Institute of Genetics and Cytology NAS of Belarus, Minsk, Belarus \\ *email: N.I.Dubovets@igc.by
}

Currently, DNA technologies occupy a leading position in the breeding programs of developed countries, which makes it possible to speed up significantly the process of creating new varieties. Among the DNA markers used in this case, SSR markers are the most in demand, especially at the stage of studying the genetic diversity of breeding material. Taking into account the fact that oat breeding in Belarus is carried out exclusively by traditional methods, we set a goal to form a set of informative SSR markers for genotyping Avena sativa L. 14 markers were selected based on the analysis of literature data, which were tested on 22 oat varieties. Half of them were Belarusian varieties, among the rest -3 varieties of European selection, 4 varieties of the Baltic selection and 4 varieties of the Russian selection. An indicator such as the value of informational polymorphism (PIC) was used to assess the effectiveness of the used marker system. Primer pairs to two monomorphic loci $A M 15$ and $A M 38$ had a zero PIC value in all studied cultivars, and only one pair of primers to the $A M 83$ locus, which revealed 2 alleles, was moderately informative. The remaining 11 markers were highly informative according to the classification of Botstein et al. (1980) with PIC variation from 0.57 to 0.93 . All of them are included in the set for the study of genetic variability of oat cultivars. Of these, 7 markers (AM4, AM5, AM7, AM11, AM14, AM22, and AM30) with a PIC in the range from 0.82 to 0.93 are recommended for differentiation of closely related genotypes and varieties certification. The use of the created set of markers will make it possible to assess the level of genetic variability of the varietal gene pool involved in the breeding process on the territory of Belarus, to determine the degree of genotype relationships, and, as a result, to more efficiently select parental pairs during hybridization. 


\title{
ISSR and SSR markers in assessing genetic diversity of Orobanche cumana
}

\author{
Duca M., Port A., Clapco S.*, Martea R., Mutu A. \\ Centre of Functional Genetics, Moldova State University, Republic of Moldova \\ *email: clapcostela@gmail.com
}

\begin{abstract}
Among molecular markers, Inter Simple Sequence Repeats (ISSR) and Simple Sequence Repeats (SSR) have been successfully used in population genetic studies. In present research 13 ISSR and 12 SSR markers were employed in order to determine the genetic diversity and relationships among 39 broomrape populations, collected from different regions of Republic of Moldova (Northern - N, Central - C and Southern - S) and belonging to different races (E, F, G and $\mathrm{H}$ ). The level of genetic polymorphism, obtained with two types of markers where convergent, demonstrating that the combination of methods are important for establishment of genetic variation among $O$. cumana populations and races differentiation. Thus, the comparative analysis of PIC index revealed the values ranging from 0.27 to 0.77 with a mean value 0.57 and 0.23 to 0.48 with mean value 0.40 , for SSR and ISSR markers respectively. The Mantel test showed higher values of correlation coefficients between the races $E$ and $G(0.731), G$ and $H(0.622)$, E and $H(0.575)$ in case of SSR analysis and, respectively, 0.702; 0.670; 0.669 in case of ISSR analysis. The multiple correlation coefficients (Pearson) for broomrape populations with distinct geographic origin were quasi similar for both markers: $(\mathrm{N}: \mathrm{C})=0.395(\mathrm{SSR})$ and $0.409(\mathrm{ISSR}) ;(\mathrm{N}: \mathrm{S})=0.427(\mathrm{SSR})$ and $0.396(\mathrm{ISSR})$; $(\mathrm{C}: \mathrm{S})=0.673$ (SSR) and 0.631 (ISSR). The data obtained as a result of analysis using SSR and ISSR markers demonstrate a higher degree of genetic similarity of $O$. cumana populations from the Central and Southern regions of the country and of the race $\mathrm{E}$ of broomrape with $\mathrm{G}$ and $\mathrm{H}$.

Acknowledgements: This study was carried out with funding from the national research project 20.80009.5107.01 „Genetico-molecular and biotechnological studies of the sunflower in the context of sustainable management of agricultural ecosystems".
\end{abstract}




\title{
Identification and variation analysis of long non-coding RNA genes expressed at early stages of seed development in Triticale
}

\author{
Dudnikov M. ${ }^{1,2 *}$, Kovlagina M. ${ }^{1}$, Soloviev A. ${ }^{1}$, Kirov I. ${ }^{1,2}$ \\ ${ }^{1}$ Laboratory of Marker-Assisted and Genomic Selection of Plants, All-Russia Research Institute \\ of Agricultural Biotechnology, Moscow, Russia \\ ${ }^{2}$ Kurchatov Genomic Center of ARRIAB, All-Russia Research Institute of Agricultural Biotechnology, \\ Moscow, Russia \\ * email: max.dudnikov.07@gmail.com
}

The seed development is the most important physiological process that directly affects the yield. Today, the transcripromic changes during grain development has been well studied and the genes involved in this process have been annotated in wheat. But most of the studies focused on the protein coding RNAs while long-non coding RNAs expressed during seed development remain unexplored. To fill in this gap, we exploited Nanopore direct RNA sequencing of RNAs isolated from triticale (AABBRR, $2 n=6 x=$ $=42$ ) seeds at 10-day post anthesis. Using this data, we identified 796 long non-coding RNAs (lncRNAs) expressed in the early stages of triticale seed development, most of which have not been previously annotated. Exonic, intronic, antisense and intergenic lncRNAs were found. For further analysis, lncRNAs of A and B genomes were taken and polymorphism of their genes in triticale collection was studied. We identified different alleles of lncRNAs genes providing useful information for further functional studies and marker-assisted selection of triticale.

Funding: This research was funded by the Ministry of Education and Science of Russian Federation (Goszadanie No. 0431-2019-0005). 


\title{
Genomic signatures of flax diversification and improvement
}

\author{
Duk M. ${ }^{1}$, Kanapin A. ${ }^{1}$, Samsonova A. ${ }^{1}$, Rozhmina T. ${ }^{2}$, Samsonova M. ${ }^{1}$ \\ ${ }^{1}$ Peter the Great St. Petersburg Polytechnic University, St. Petersburg, Russia \\ ${ }^{2}$ Federal Research Centre for Bast Fiber Crops, Torzhok, Russia \\ *email: m.samsonova@spbstu.ru
}

Flax is a founder crop domesticated by humans since Neolithic times. Flax cultivation spread from the Fertile Crescent into Indian subcontinent, Central Asia, Mediterannean and East Africa, thus forming centers of secondary diversity (Vavilov, 1926, 1951), where the crop management practices were adapted to specific geographic regions and patterns of use. Through these processes two main subgroups of the crop appeared, namely fiber flax and oil flax. By the end of the XIX century northern regions of Russia became major flax production centres, where spontaneous selection carried out by local peasantry led to the development of local landraces (i.e. kryazhs).

In this study we present new insights into genetic diversity of 306 flax accessions from collection of the Federal Research Center for Bast Fiber Crops, encompassing landraces, elite cultivars and breeding lines.

Our results demonstrate that the population structure of flax recapitulates the crop subdivision into subgroups, as well as into landraces and cultivars. Signatures of gene flow in kryazh landraces were detected from both landraces originated to the West (Mediteranean, West Asia, Caucasus, Egypt) and to the East (Central Asia, Pakistan, North China) of Caspian sea. These findings challenge the hypothesis regarding kryazh landraces Central Asian origin (Zhykovsky, 1971). Genomic variation in plants attributed to the centers of secondary diversity correlates with geography and climate features. Regions with negative Tajima $\mathrm{D}$ values were found on most chromosomes in elite cultivars and breeding lines suggesting strong selection accompanying the crop improvement history. A comparison of regions of reduced diversity (e.g. high $\mathrm{F}_{\mathrm{st}}$ ) between krjazh landraces and cultivars pinpointed genomic loci under selection, which are presumably associated with the most recent breeding efforts of fiber flax. Furthermore, by thorough analysis of cultivars we reconstructed the fiber flax breeding history.

Acknowledgments: This work was supoorted by RSF fund, grant 19-16-00030.

60 PlantGen2021 


\title{
Z-ISO: a catching up step towards formation of colored carotenoids in tomatoes
}

\author{
Efremov G.I.*, Shchennikova A.V., Kochieva E.Z. \\ Federal Research Centre "Fundamentals of Biotechnology" RAS, Moscow, Russia \\ *email: gleb_efremov@mail.ru
}

Carotenoid biosynthesis in fleshy fruits has several critical steps, one of which is the isomerization of 9,15,9'-tri-cis- $\zeta$-carotene, mediated by Z-ISO (15-cis- $\zeta$-carotene isomerase). This enzyme is considered a gatekeeper of the carotenoid pathway, especially in tissues without light exposure. In total, 20 complete Z-ISO homologs, including the 5'-UTR and the promotor, were identified in 12 Solanum lycopersicum cultivars and eight accessions of wild tomato species $S$. pimpinellifolium, S. cheesmaniae, $S$. chilense, $S$. habrochaites, and $S$. pennellii, differing in fruit color and carotenoid content. Compared to the Z-ISO of cv. Heinz 1706, the variability of the identified genes was $14.98 \%$ (complete sequences), $10.36 \%$ (exons), $21.50 \%$ (5'-UTR), and $17.89 \%$ (promoter). All putative Z-ISO proteins were 369 aa and contained a 58-aa transit peptide and a 15-cis-zeta-carotene isomerase domain. Comparative structural analysis of Z-ISO homologs identified 20 conserved motifs, 10 of which were common, and the other 10 were species-specific. Z-ISO enzymes of analyzed accessions contained 24 radical aa substitutions compared to cv. Heinz Z-ISO. Z-ISO expression was analyzed in leaves and fruits (immature green, mature green, breaker, and ripe) of S. lycopersicum cv. Heinz, Korneevskii, and Kopilka zheltaya, as well as $S$. cheesmaniae, S. habrochaites and $S$. pennellii accessions. The expression level of Z-ISO was found to correlate with the color and carotenoid content of the fruit. In fruits of red-fruited cv. Heinz and Korneevskii with abundant lycopene and yellow-fruited cv. Kopilka zheltaya with high $\beta$-carotene content, Z-ISO transcription was 10-20 times higher than in S. cheesmaniae pale yellow fruits with $\beta$-carotene traces and a lack of lycopene at the breaker and ripe stages respectively. The lowest expression was in fruits of green-fruited $S$. habrochaites and $S$. pennellii. In leaves, Z-ISO expression was significantly higher in cv. Heinz than in other cultivars and species, where it remained low or absent.

Acknowledgments: This study was supported by the Russian Science Foundation (grant No. 19-16-00016), and, partially, by the Ministry of Science and Higher Education of the Russian Federation. 


\section{Developing potato varieties with decreased cold-induced sweetening}

Egorova A. ${ }^{1,2 *}$, Gerasimova S. ${ }^{1,2}$, Ibragimova S. ${ }^{1}$, Romanova A. ${ }^{1}$, Saboiev I. ${ }^{1}$, Domrachev D. ${ }^{5}$, Koeppel I. ${ }^{3}$, Hertig C. ${ }^{3}$, Hiekel S. ${ }^{3}$, Chamas S. ${ }^{3}$, Kumlehn J. ${ }^{3}$, Rogosina E. ${ }^{4}$, Chalaya N. ${ }^{4}$, Salina E. ${ }^{1}$, Kochetov A. ${ }^{1,2}$

${ }^{1}$ Kurchatov Genomic Center of the Institute of Cytology and Genetics, SB RAS, Novosibirsk, Russia

${ }^{2}$ Novisibirsk State University, Novosibirsk, Russia

${ }^{3}$ Leibniz Institute of Plant Genetics and Crop Plant Research, Gatersleben, Germany

${ }^{4}$ N.I. Vavilov All-Russian Institute of Plant Genetic Resources, St. Petersburg, Russia

${ }^{5}$ Institute of Organic Chemistry SB RAS, Novosibirsk, Russia

*email: egorova@bionet.nsc.ru

Commercial storage of potato at low temperatures $\left(4-6{ }^{\circ} \mathrm{C}\right)$ leads to the degradation of starch into reducing sugars, referred to as cold-induced sweetening (CIS). Upon processing at high-temperature, these sugars react with free amino acids, resulting in brown, bitter-tasting products. Vacuolar invertase breaks down sucrose to glucose and fructose, thereby largely contributing to the accumulation of reducing sugars. Sitedirected mutagenesis of the POTATO ACID INVERTASE 1 (PAIN1) is considered as a viable strategy towards the development of varieties with decreased cold-induced sweetening. To this end, cas $9 / \mathrm{gRNA}$ vectors were constructed for target sites in this gene. After having demonstrated the mutagenic activity of the vectors in potato protoplasts these constructs were delivered into cells of local potato varieties using biolistic DNA transfer. The regeneration of transformed plants is in progress. In addition, a second strategy involves the development of CIS-resistant donors for potato breeding from wild potato genotypes. Solanum chacoense is a wild relative of cultivated potato exhibiting strong CIS resistance. However, S. chacoense is toxic owing to high amounts of steroidal glycoalkaloids (SGAs). Consequently, the development of S. chacoense derivatives with much reduced toxicity may of great benefit for potato breeding programs. Knockout of the GLYCOALKALOID METABOLISM 9 (GAME9) gene, the regulator of SGA synthesis in potato, is considered as a useful principle to reduce SGAs in plants. Two $S$. chacoense accessions were selected from the VIR genebank collection as potential trait donors, for which low accumulation of reducing sugars and high accumulation of SGAs was shown. The cas $9 / \mathrm{gRNA}$ constructs used to knock out GAME9 were created and introduced into $S$. chacoense explants.

Acknowledgements: The study is supported by the RFBR (20-016-00217) and by the Kurchatov Genomic Centre of the Institute of Cytology and Genetics, SB RAS (075-152019-1662). 


\section{Targeted modification of regulatory genes associated with barley grain color formation}

Egorova A. ${ }^{1,2 *}$, Strygina K. ${ }^{4}$, Shoeva O. ${ }^{1}$, Hertig C. ${ }^{3}$, Gerasimova S. ${ }^{1,2}$, Koeppel I. ${ }^{3}$, Hiekel S. ${ }^{3}$, Vikhorev A. ${ }^{1,2}$, Kumlehn J. ${ }^{3}$, Khlestkina E. ${ }^{4}$

${ }^{1}$ Institute of Cytology and Genetics, SB RAS, Novosibirsk, Russia

${ }^{2}$ Novisibirsk State University, Novosibirsk, Russia

${ }^{3}$ Leibniz Institute of Plant Genetics and Crop Plant Research, Gatersleben, Germany

${ }^{4}$ N.I. Vavilov All-Russian Institute of Plant Genetic Resources, St. Petersburg, Russia

*email: egorova@bionet.nsc.ru

Blue and purple colors of barley (Hordeum vulgare L.) grain are caused by anthocyanin accumulation in aleurone and pericarp respectively. Anthocyanins are known for their human health benefits. It is thus desirable to breed and grow barley with colored grains. In our previous experiments, the bHLH transcription factors MYC2 and ANT2 have been shown to be implicated in the control of barley grain pigmentation. In the present investigation, the MYC2 and ANT2 genes of barley were subjected to Cas9/gRNAmediated site-directed mutagenesis aiming to further elucidate the roles of these genes in grain color formation. It was previously shown that the loss-of-function of $H v M Y C 2$ is associated with non-colored compared to blue-grained barley. To provide compelling evidence of MYC2 function in regard to blue aleurone formation, an attempt was made to restore the reading frame of the mutated allele in non-colored barley by deleting the spontaneously inserted nucleotide. To this end, cas $9 /$ gRNA plasmids were constructed for two target sites in the HvMYC2 gene. Barley cultivar 'Golden Promise' with uncolored grains was used as experimental line for the intended modification. After Agrobacterium-mediated transformation, 49 primary mutant plants were obtained, out of which 19 featured the desired loss of a single nucleotide. To confirm the role of ANT2 in purple pericarp formation, a targeted knockout of the respective gene was required in purple-grained barley. To generate experimental lines amenable to genetic transformation, the purple PLP accession was crossed with 'Golden Promise', which was followed by the use of resulting hybrids for the knockout approach. A cas $9 / \mathrm{gRNA}$ construct was generated, containing three gRNAs for different target sites in the HvANT2 gene. Agrobacterium-mediated transformation resulted in 67 primary mutant plants. The phenotypic analysis of the generated mutants is in progress.

Acknowledgements: The work is supported by the RSF (21-66-00012). 


\title{
Improvement of sorghum seed storage protein digestibility using RNA-interference and genome editing
}

\author{
Elkonin L.A. ${ }^{*}$, Gerashchenkov G.A. ${ }^{2}$, Panin V.M. ${ }^{1}$, Kenzhegulov O.A. ${ }^{1}$, \\ Sarsenova S.Kh. ${ }^{1}$, Rozhnova N.A. ${ }^{2}$, Borisenko N.V. ${ }^{1}$ \\ ${ }^{1}$ Federal Agricultural Research Centre of South-East Region, Saratov, Russia \\ ${ }^{2}$ Institute of Biochemistry and Genetics - Subdivision of the Ufa Federal Research Centre of RAS, Ufa, \\ Russia \\ *email: lelkonin@gmail.com
}

Sorghum (Sorghum bicolor (L.) Moench) is one of the world's most important crops in agricultural production. However, unlike other cereals, sorghum grain has a lower nutritional value, the main reason for which is the resistance of its seed storage proteins (kafirins) to proteolytic digestion. Suppressing the synthesis of individual kafirin subclasses is an effective approach to solve this problem, since distortion of the prolamine synthesis in cereals leads to a rebalancing of the kernel proteome, and to the synthesis of other proteins with a higher content of the essential amino acids, and to increase of endosperm protein digestibility. This goal can be achieved by genetic transformation using the constructs capable for RNAi silencing of kafirin genes or genome editing by introducing mutations into the nucleotide sequences of these genes. In the grain sorghum commercial cultivar Avans, using Agrobacterium-mediated genetic transformation we obtained the RNAi-mutant bearing the genetic construct for RNAsilencing of the $\gamma$-kafirin gene $(g K A F 1)$. The mutant is characterized by complete disappearance of the vitreous endosperm layer, which in this cultivar has dark color and contains tannins interfering with protein digestibility. SDS-PAGE showed that the mutant has reduced content of kafirins. Analysis of endosperm protein digestibility showed significantly higher level of this trait compared to the original non-transgenic cultivar (93 against 57-62\%). The genetic construct for silencing was inherited under self-pollination and in hybridization with CMS-lines. In order to use genome editing we have created two series of vectors, which contain genomic target motifs (23 bp sequences) of the $\alpha$-kafirin (p1C, p2C, p05, p06) and $\gamma$-kafirin (p3C, p4C, p07, p08) genes, Cas 9 gene, and the marker gene bar. Using these vectors, we have obtained transgenic sorghum plants, which are currently investigated.

Acknowledgments: The work was funded in part by the Russian Foundation for Basic Research, grant 19-016-00117. 


\title{
Applying neural network for the segmentation of spike structural elements
}

\author{
Epifanov R.1,3*, Genaev M.1,2,3 \\ ${ }^{1}$ Novosibirsk State University, Novosibirsk, Russia \\ ${ }^{2}$ Institute of Cytology and Genetics, SB RAS, Novosibirsk, Russia \\ ${ }^{3}$ Kurchatov Genomic Center of the Institute of Cytology and Genetics, SB RAS, Novosibirsk, Russia \\ * email: rostepifanov@gmail.com
}

The shape and structure of the wheat spike is one of the most important characteristics of cereals associated with their economically valuable qualities such as productivity, the absence of ear fragility and ease of threshing. The study of the genes controlling these traits will allow us to purposefully create new varieties with improved characteristics in terms of yield, ease of thresh and resistance to environmental factors. Evaluation of wheat spike characteristics in most modern studies is performed by an expert based on the visual analysis and measuring practices, which requires a significant investment of time, despite the fact that in modern experiments tens of thousands of plants are analyzed. Automation of this time-consuming process through the introduction of digital image analysis technologies is relevant for modern science. Important step in wheat morphometric analysis is spike structural element segmentation at body and awns of spike. In this work, we propose a method based on neural networks to segment ear structural elements. The algorithm is based on usage of Unet. Model accuracy according to the IoU metric was $94.73 \%$ for the body and $77.70 \%$ for the awns of wheat, which is 2.23 and $11.70 \%$ higher than that of the WERecognizer model posted on wheatdb.org/werecognizer.

Acknowledgements: This work was supported by the Kurchatov Genomic Center of the Institute of Cytology and Genetics, SB RAS (agreement No. 075-15-2019-1662). 


\title{
Paralogous genes of centromeric histone CENH3 are actively expressed in the rye genome
}

\author{
Evtushenko E.V. ${ }^{1 *}$, Gatzkaya S.S. ${ }^{1}$, Grishko E.O. ${ }^{1,2}$, Vershinin A.V. ${ }^{1,2}$ \\ ${ }^{1}$ Institute of Molecular and Cellular Biology, SB RAS, Novosibirsk, Russia \\ ${ }^{2}$ Novosibirsk State University, Novosibirsk, Russia \\ *email: evt@mcb.nsc.ru
}

In most diploid plant species, centromeric histone $\mathrm{H} 3$ (CENH3) is encoded by a single copy of the gene. However, for rye species, as well as for other species of the tribe Triticeae, the presence of two genes, $\alpha C E N H 3$ and $\beta C E N H 3$, was shown. The occurrence of $\mathrm{CENH} 3$ in chromatin is essential for kinetochore formation and proper centromere functioning. The presence of the $C E N H 3$ duplication raises the following questions: are both paralogs expressed during plant ontogenesis, is one of the paralogs a pseudogene, are both variants of the $\mathrm{CENH} 3$ protein involved in the formation of an active centromere, and is the centromere the only region of their localization? In this work, the transcription profiles of $\alpha C E N H 3$ and $\beta C E N H 3$ were determined by the RT-qPCR method in two cultivars of rye $S$. cereale, 'Imperial' and 'Korotkostebelnaya 69'. It was found that both genes, $\alpha C E N H 3$ and $\beta C E N H 3$, are expressed at all stages of individual development: in the tissues of seedling roots, coleoptiles, stems, anthers and carpels. The highest level of expression of both $\mathrm{CENH} 3$ variants was found in reproductive tissues (anthers and carpels); expression level of evolutionarily ancient $\alpha C E N H 3$ exceeds that of the evolutionarily young $\beta C E N H 3$ in almost all tissues. The incorporation of two CENH3 variants into centromeres was investigated by immunostaining the chromosomes of Imperial with specific anti- $\alpha \mathrm{CENH} 3$ and anti- $\beta \mathrm{CENH} 3$ antibodies. It was revealed that $\alpha \mathrm{CENH} 3$ and $\beta \mathrm{CENH} 3$ are co-localized on centromeres in the interphase nucleus and in the metaphases of mitosis and the first division of meiosis. The presented data indicate the transcription of two CENH3 genes and the incorporation of functional $\mathrm{CENH} 3$ variants into centromeres differ in various tissues of rye during plant development.

Acknowledgements: This research was financially supported by the Russian Fundamental Scientific Research Program (project 0246-2021-0014), Russian Science Foundation (project No. 19-14-00051) and the Russian Foundation for Basic Research (grant 20-04-00699 A). 


\section{Non-phosphorylating alternative respiratory pathways are involved in an increase of wheat resistance to heat stress}

Fedotova O.A. ${ }^{1}$, Polyakova E.A. ${ }^{1,2 *}$, Grabelnych O.I. ${ }^{1,2}$

${ }^{1}$ Siberian Institute of Plant Physiology and Biochemistry, SB RAS, Irkutsk, Russia

${ }^{2}$ Irkutsk State University, Irkutsk, Russia

*email: polyackova.elizaveta727@yandex.ru

The non-phosphorylating alternative pathways of plant mitochondria are presented by the alternative cyanide-resistant oxidase (AOX) and rotenone-insensitive internal (NDA) and external (NDB) type II NAD(P)H dehydrogenases (NAD(P)H-DH). The physiological significance of these respiratory pathways is actively studied. Regulation of alternative pathways occurs both at the levels of gene expression and posttranslationally and strongly depend on the physiological state of the plant and growth conditions.

The influence of heat treatments on the heat stress tolerance of spring wheat (Triticum aestivum L.) and its relation with the alternative pathways, content of water-soluble carbohydrates in leaves, content of ROS, and regulation of the production of ROS by alternative respiratory pathways were determined.

Heat treatment $\left(39^{\circ} \mathrm{C}\right.$ for $\left.24 \mathrm{~h}\right)$ led to an increase in the heat resistance of wheat and the accumulation of water-soluble carbohydrates. AOX, NDA, NDB were activated by heat treatment and its activation was also high after the subsequent influence of heat stress $\left(50{ }^{\circ} \mathrm{C}\right.$ for $\left.3 \mathrm{~h}\right)$. The content of AOX protein isoforms depended on the intensity and duration of heat treatments. Heat treatments $\left(37\right.$ and $\left.39^{\circ} \mathrm{C}\right)$ revealed the increased AOX contribution and high rate of NADH oxidation. In addition, the content of AOX protein depends on the wheat development phase under high temperatures. Heat treatment reduced mitochondrial peroxide level, but the subsequent influence of heat stress led to its increase. The antioxidant function of AOX was revealed. However, this function is not the main at high temperatures in photosynthetic plants. Moreover, slight increase of peroxide was noted upon inhibition of complex I of the respiratory chain during heat treatment, which may indicate a possible role of $\mathrm{NAD}(\mathrm{P}) \mathrm{H}-\mathrm{DH}$ in the formation of ROS. Thus, the data obtained indicates the important role of alternative respiratory pathways in the adaptation of wheat to high temperatures.

Acknowledgments: This work is supported by the grant of the President of the Russian Federation (MK-1720.2020.4). 


\title{
Triplet composition of common mitochondrial and chloroplast genes of plants reveals their differentiation
}

\author{
Fedotovskaya V. ${ }^{1 *}$, Sadovsky M. ${ }^{2,3,4}$ \\ ${ }^{1}$ Siberian Federal university, Krasnoyarsk, Russia \\ ${ }^{2}$ Institute of computational modelling of SB RAS, Krasnoyarsk, Russia \\ ${ }^{3}$ V.F. Voino-Yasenetsky Krasnoyarsk state medical university, Krasnoyarsk, Russia \\ ${ }^{4}$ Siberian research \& clinic center of FABM of Russia, Krasnoyarsk, Russia \\ * email: viktoriia.fedotovskaia@gmail.com
}

The problem of interplay of structure of nucleotide sequences, functions encoded in them, and taxonomy of their bearers still challenges researchers. We studied the relation between triplet composition of genes and taxonomy of the bearers. We compared mitochondrial and chloroplast genes common for both organelles of the same species. There are two families of such genes: genes encoding ATP synthase and those of NADH dehydrogenase. 11 ATP synthase genes have been studied: mitochondrial atp1, atp4, atp6, atp8, atp9 and chloroplast atp $\mathrm{A}, \operatorname{atp} \mathrm{B}, \operatorname{atp} \mathrm{E}, \operatorname{atp} \mathrm{F}, \operatorname{atp} \mathrm{H}$, atpI. Totally, 170 (85 mitochondrial and 85 chloroplast) plant genomes were studied. Each gene sequence was transformed into triplet frequency dictionary, where the reading frame shift was equal to $t=1$. The relation is revealed through the unsupervised clustering via elastic map implementation of the points in 64-dimensional space of the triplet frequencies of the genes. Three types of clustering have been analysed: for mitochondria genes solely, for chloroplast genes solely, and for the merged set of the genes from both organelles' genomes. We used ViDaExpert software. The encoded function was found to be the key feature in clustering: all the clusters in all three versions of clustering patterns clearly exhibit distinct separation of the genes encoding the same subunit into a separate cluster. This behaviour was found for all three types of cluster patterns. Thus, an evidence of the prevalence of function over the taxonomy was shown, for ATP synthase genes family of mitochondrial and chloroplast genomes of plants. 


\section{Analysis of liguleless1 gene associated with ligule development in Zea mays $\mathrm{L}$.}

Filyushin M.A. ${ }^{1 *}$, Khatefov E.B. ${ }^{2}$, Kochieva E.Z. ${ }^{1}$, Shchennikova A.V. ${ }^{1}$

${ }^{1}$ Institute of Bioengineering, Federal Research Centre "Fundamentals of Biotechnology"

of the Russian Academy of Sciences, Moscow, Russia

${ }^{2}$ N.I. Vavilov Institute of Plant Genetic Resources, St. Petersburg, Russia

*email: michel7753@mail.ru

The maize ligule is an adaxial membranous structure on the leaf that develops at the boundary of the sheath and blade. The degree of ligula development determines the inclination angle of maize leaves. Ligule formation is controlled by the liguleless $1(\lg 1)$, $\operatorname{lh} 2, \lg 3$, and $\lg 4$ genes, which encode transcription factors (TF) of diverse families. In this study, we present an analysis of $\lg 1$ homologous genes encoding SBP TF in maize accessions of different origin. Performed structural and phylogenetic analysis showed that in modern maize genome the $\lg 1$ gene is present in two copies $(\lg 1$ and $\lg 1-2)$, and the $\lg 1-2$ gene may originate from the genome of teosinte (Zea mays subsp. mexicana), in which it is represented by one copy. The homology of $l g 1-2$ from teosinte with $\lg 1$ gene in different maize genotypes was 97-99\%; a high homology of the promoter regions (> 90\%) was also observed. In total, 20 maize accessions were selected for analysis, differing in the angle of leaf inclination. $L g l$ gene homologs, including the promoter regions, were amplified, cloned and sequenced using the designed genespecific primers. An analysis of the variability of the identified genes showed that the end of exon 1 and the entire exon 2 encoding the SBP domain are invariant in the studied accessions, while the promoters are polymorphic; no associations of substitutions and indels with the phenotype were found. In accessions with leaves located perpendicular to the stem, the synonymous substitution C941T was revealed. Not a single mutation in the $\lg 1$ gene was found that would lead to its inactivation.

Acknowledgements: This study was supported by the Russian Science Foundation (grant 21-16-00008) and the Ministry of Science and Higher Education of the Russian Federation. 


\section{Agrobacterium-mediated transformation of Chrysanthemum with artemisinin biosynthesis pathway genes}

Firsov A. ${ }^{1}$, Mitiouchkina T. ${ }^{1}$, Shaloiko L. ${ }^{1}$, Pushin A. ${ }^{1}$, Vainstein A. ${ }^{2}$, Dolgov S. ${ }^{1 *}$

${ }^{1}$ Branch of the Shemyakin-Ovchinnikov Institute of Bioorganic Chemistry of the RAS, Moscow Region, Pushchino, Russia

${ }^{2}$ The Hebrew University of Jerusalem, Robert H. Smith Faculty of Agriculture, Food and Environment, POB 12, Rehovot, Israel

*email:dolgov@bibch.ru

Artemisinin-based drugs are the most effective medicine for the malaria treatment. To date, the main method of artemisinin production is its extraction from wormwood plants Artemisia annua L. Due to the limitation of this source, considerable efforts are now directed to the development of methods for artemisinin production using heterologous expression systems. Artemisinin is a sesquiterpene lactone, synthesized through the cyclization of farnesyl diphosphate involved in other sesquiterpene biosynthetic systems. Chrysanthemum species as well as A. annua, belong to Asteraceae family, and had been characterized by containing highly content of sesquiterpenes and their precursors. This makes chrysanthemum a promising target for the production of artemisinin in heterologous host plants. Chrysanthemum (C. morifolium Ramat.) was transformed by Agrobacterium tumefaciens carrying with the binary vectors p1240 and p1250, bearing artemisinin biosynthesis genes coding: amorpha-4,11-diene synthase, artemisinic aldehyde $\Delta 11$ (13) reductase, amorpha-4,11-diene monooxygenase (p1240 was targeted to the mitochondria and p1250 was targeted to the cytosol), cytochrome P450 reductase from $A$. annua, as well as yeast truncated 3-hydroxy-3-methylglutarylcoenzyme A reductase. This study obtained 8 kanamycin-resistant lines after transformation with the p1240 and 2 lines from p1250. All target genes were detected in 2 and 1 transgenic lines of the 2 vectors. The transformation frequency of all target genes were 0.33 and $0.17 \%$ for p1240 and p1250, relative to the total transformed explant numbers. RT-PCR analysis revealed the transcription of all transferred genes in two lines obtained after transformation with the p1240 vector, confirming the possibility of transferring genetic modules encoding entire biochemical pathways into the chrysanthemum genome. This holds promise for the development of a chrysanthemum-based expression system to produce non-protein substances, such as artemisinin. 


\section{StCDF 1 gene editing strategy in potato wild species within de novo domestication concept}

Fomin I.N. ${ }^{1 *}$, Egorova A.A. ${ }^{1,2}$, Koloshina K.A. ${ }^{1}$, Gerasimova S.V. ${ }^{1}$

${ }^{1}$ Institute of Cytology and Genetics, SB RAS, Novosibirsk, Russia

${ }^{2}$ Novosibirsk State University, Novosibirsk, Russia

*email:ifomin@bionet.nsc.ru

During long selection process modern potato cultivars have lost their ability to resist various negative environmental factors, while many wild species have retained these traits. As part of the de novo domestication concept, we are looking for genes with modification potential supposed to accelerate the production of new trait donors for their introduction into breeding. One of such genes is $S t C D F 1$, which is involved in the regulation of tuberization. The wild-type allele (StCDF1.1) mediates good tuberization under short-day conditions, whereas under long-day conditions (typical for our latitudes) tuberization does not occur or strongly suppressed. The mutant allele (StCDF1.2) provides good tuberization under long day conditions and differs from the wild-type allele by an earlier stop codon causing the absence of one of the protein domains at the C-terminus. The aim of this work is to modify the StCDF1 gene in selected wild potato species using the Cas9/gRNA system to induce tuberization under long day conditions. As a result of phenotyping the ICG wild potato collection the few potato accessions with delayed tuberization were identified. The structure of the $C D F 1$ gene was examined in selected genotypes. The target site selection and gRNA design for induction of desired modification were performed.

Acknowledgements: the study is funded by RFBR, project number 20-016-00217. 


\section{$C L E$ genes in tuber development in potato (Solanum tuberosum $\mathbf{L}$.)}

Gancheva M.S. ${ }^{1,2 *}$, Dodueva I.E. ${ }^{1}$, Lutova L.A. ${ }^{1}$

${ }^{1}$ Saint-Petersburg State University, St. Petersburg, Russia

${ }^{2}$ All-Russia Research Institute for Agricultural Microbiology, St. Petersburg, Russia

*email: ganchovai@gmail.com

The peptide hormones CLE are involved in maintaining plant meristems and in response to various environmental factors. We identified 36 CLE genes in potato Solanum tuberosum (StCLE). Using expression analysis we identified possible regulators of thickening (StCLE8 and StCLE12) and participants of response to nitrogen (StCLE4 and StCLE10). We have shown that the promoters of the StCLE8 and StCLE12 genes are active in the cells of the vascular bundles of stolons and stems, as well as in tubers. Next, we studied the effect of overexpression of the StCLE8 and StCLE12 genes, as well as overexpression of the antagonistic genes StCLE8 and StCLE12 - which carried a codon substitution in its core CLE motifs that, when such peptides interact with receptors, lead to blocking of signal transmission. We found that changes in the expression levels of the StCLE8 and StCLE12 genes affect the structure of the vascular bundles in the stem and stolon, tuber growth, leaf shape, and internode length. We also studied the activity of the promoters of the StCLE4 and StCLE10 genes in the roots growing in a medium with and without nitrogen. We have shown that the promoters of these genes are active in a medium with nitrogen, which makes them possible signals mediating nitrogen nutritional response. We analyzed root growth and the ability to form tubers in plants with overexpression of the StCLE4 gene and antagonistic StCLE4.

Acknowledgements: The work was made with support of the Ministry of Science and Higher Education of the Russian Federation in accordance with agreement No. 075-152020-922 date 16.11.2020 on providing a grant in the form of subsidies from the Federal budget of Russian Federation. The grant was provided for state support for the creation and development of a World-class Scientific Center "Agrotechnologies for the Future". 


\title{
IRAP-analysis of genetic diversity in Chinese plum (Prunus salicina) varieties distributed in southern regions of Siberia
}

\author{
Garapov D.S. ${ }^{1 *}$, Stepanov I.V. ${ }^{2}$ \\ ${ }^{1}$ Federal Altai Scientific Center For Agrobiotechnology, Barnaul, Russia \\ ${ }^{2}$ North Caucasian Federal Scientific Center For Horticulture, Viticulture, Wine-Making, Krasnodar, \\ Russia \\ *email: prunus@inbox.ru
}

Far Eastern plums originated from hybridization of Ussurian plum (Prunus ussuriensis) local forms with Chinese plum (Prunus salicina) varieties from northern China. The introduction of plum varieties from Far East led to selection of new varieties from openpollinated populations in Siberia. Some Chinese plum hybrids with Simon plum (Prunus simonii) and Ussurian plum were introduced from European part of Russia. The aim was to study genetic diversity of local and introduced plum varieties in Siberia using IRAP method. Young leaves of 12 plum varieties were obtained from field collection in Federal Altai Scientific Center For Agrobiotechnology (Barnaul, Russia). Primers PrunCassLTR1 and PrunCassLTR2 used in the current study were designed in Slovak University of Agriculture and derived from European plum (Prunus domestica) retrotransposon Cassandra (AY860314). The primers showed to be highly polymorphic across European plum cultivars in the previous research. DNA extraction and PCR amplifications were performed in North Caucasian Federal Scientific Center For Horticulture, Viticulture, Wine-Making (Krasnodar, Russia) according to the previous study. Primer PrunCassLTR1 amplified 12 bands of which 11 were polymorphic; primer PrunCassLTR2 amplified 16 bands, all polymorphic. The size of amplified products ranged from 200 to $1000 \mathrm{bp}$ for Cass 1 and from 140 to $1500 \mathrm{bp}$ for Cass2, the effective number of alleles was 1.563 and 1.535 , Nei's genetic diversity was 0.341 and 0.324 , Shannon's information index was 0.511 and 0.494 respectively. Varieties 'Duduka', 'Zheltaja Khopty' and 'Pamyati Putova' were genetically distinct from the other plums by cluster analysis. In PCO plot, 'Altajskaja Jubilejnaja' and 'Ksenija' could also be separated from the other cultivars. The rest varieties were divided into 2 groups: derivates of 'Primorskaja' and derivates of 'Mandzhurskaja krasavitsa'. Close genetic relationship was found between varieties 'Vika' and 'Uzyuk' (similarity index 0.96), 'Belovskaja krasavitsa', 'Peresvet' and 'Chemal'skaja sinyaja' (0.81-0.85), 'Mandzhurskaja krasavitsa' and 'Belovskaja krasavitsa' (0.80). Principal coordinate analysis revealed similar results. 


\title{
Study of the effect of nutrient medium components on the regenerative abilities rapeseed explants (Brassica napus), Antares variety
}

\author{
Garibyan Ts.S.*, Konstantinov Z.S., Zakharova E.V. \\ All-Russia Research Institute of Agricultural Biotechnology, Moscow, Russia \\ * email:tsovinar1980@mail.ru
}

Rapeseed has a number of valuable agricultural and technical properties, and is of high relevance for various applications, which determines the significant interest to this crop. In relation with this, a further comprehensive study and improvement of this culture is required. In addition to traditional breeding methods, technologies of in vitro-induced somaclonal variability are gaining an important role. The variety Antares of spring rapeseed, belonging to type 00 was selected for this study. Parts of the hypocotyl and leaf plates were used as explants. One of the main factors is the amount and ratio of phytohormones in the nutrient medium. Based on this, the aim was to study the effect of hormonal components of the nutrient medium on the callus and organogenesis of rapeseed. Explants were planted on the MS culture medium with the addition of phytohormones of different concentrations. 6-BAP and NAA were used as the cytokinin and auxin group hormone respectively. The concentrations of each of the phytohormones were as follows: $0.1,0.5,1.0,1.5 \mathrm{mg} / \mathrm{l}$. It was found that the optimal nutrient medium for successful and intensive callus formation is the medium with the addition of $1 \mathrm{mg} / \mathrm{l}$ $\mathrm{NAA}+1 \mathrm{mg} / \mathrm{l} \mathrm{6-BAP}$ and $1 \mathrm{mg} / \mathrm{l} \mathrm{NAA}+1.5 \mathrm{mg} / \mathrm{l} \mathrm{6-BAP}$. The experiment also revealed the optimal ratio of phytohormone concentrations for the successful production of somaclonal plants $(1.5 \mathrm{mg} / \mathrm{l}$ of $\mathrm{NAA}+1 \mathrm{mg} / \mathrm{l}$ of 6 -BAP). The influence of phytohormones in the nutrient medium on the callus and organogenesis of rapeseed was studied and their optimal concentrations were determined.

Acknowledgements: The work was completed within the framework of the state task No. 0431-2019-0005. Kurchatov Genomic Center of All-Russia Research Institute of Agricultural Biotechnology No. 075-15-2019-1667. 


\section{The dark-induced senescence disruption in Arabidopsis thaliana glutamate dehydrogenase knockout mutant gdhlgdh2}

Garnik E.Yu. ${ }^{1 *}$, Vlasova A.A. ${ }^{1,2}$, Belkov V.A. ${ }^{1}$, Tarasenko V.I. ${ }^{1}$, Konstantinov Yu.M. ${ }^{1,2}$

${ }^{1}$ Siberian Institute of Plant Physiology and Biochemistry SB RAS, Irkutsk, Russia

${ }^{2}$ Irkutsk State University, Irkutsk, Russia

*email: elga74@yandex.ru

Plant senescence is a programmed process aimed at remobilization and redistribution of resources from senescing organs to the youngest, including flowers or fruits, or to storage organs. In a laboratory, leaf senescence can be started by a long (several days) keeping the plants in the dark (dark-induced senescence, DIS). We found that the Arabidopsis glutamate dehydrogenase knockout mutant $g d h 1 g d h 2$ does not demonstrate typical traits of senescence during the dark exposition. DIS program disruption in the mutant plants is observed on several levels, such as a slowdown in the chlorophyll degradation, an absence of the senescence associated genes and some transcription factors induction, and a slowdown in the photosynthetic supercomplexes degradation. The dark-exposing gdhlgdh2 plants are not sensitive to abscisic acid spraying, unlike the wild type ones, although abscisic acid sensitivity of the mutant seeds during germination is not reduced. Ion leakage in the dark-exposing mutant plants increases much sooner than in the wild type ones, which reflects a rapid and significant decrease in a viability in the mutant plants. We assume that in the dark-exposed gdhlgdh2 plants, as a result of glutamate dehydrogenase loss, some metabolic rearrangements lead to accumulation of free ammonium and the toxic effects associated with it, while the normal DIS program is not activated. 


\title{
Dynamics of the transcription of $\mathrm{CENH} 3$ genes in allopolyploid hybrids of wheat and rye
}

\author{
Gatzkaya S.S. ${ }^{1 *}$, Evtushenko E.V. ${ }^{1}$, Vershinin A.V. ${ }^{1,2}$ \\ ${ }^{1}$ Institute of Molecular and Cellular Biology SB RAS, Novosibirsk, Russia \\ ${ }^{2}$ Novosibirsk State University, Novosibirsk, Russia \\ * email: jait@mail.ru
}

Remote hybridization is a stress factor that causes reorganization of parental genomes in hybrid offspring ("genomic shock"). The main manifestations of this are various chromosomal abnormalities which can affect the structure of centromeres, thus cause chromosomal abnormalities in meiosis and hybrids sterility. The centromeric histone $\mathrm{H} 3$ (CENH3) is a key component in the proper centromere functioning. Two genes, $\alpha C E N H 3$ and $\beta C E N H 3$, were found in the genomes of the Triticeae species. They are different in size, exon-intron structure and amino acid composition of the NTT domain. We investigated the effect of remote hybridization on molecular characteristics of centromeres in allopolyploid rye-wheat hybrids. We found that the parental forms, wheat (AABBDD) and rye (RRRR), differ in centromere sizes, that indicates the species specificity of this characteristic. Centromeres of stable hybrids triticale (AABBRR) and secalotriticum (RRAABB) have intermediate sizes. The study of CENH3 genes transcription revealed that both $\alpha C E N H 3$ and $\beta C E N H 3$ are transcribed in all stages of individual development. Paralogs transcription profiles during ontogenesis of secalotriticum (Secalotriticum Verasen $\times$ Mikhas and Verasen $\times$ Dubrava) and parental species (rye S.cereale 'Verasen' and Triticale 'Mikhas' and 'Dubrava') were identical. The expression levels of $\alpha C E N H 3$ exceed the corresponding values of $\beta C E N H 3$ by an order of magnitude. The transcription levels of CENH3 genes significantly decrease in vegetative tissues (almost 10 times lower in leaf tissue than in coleoptiles), and increase many times in reproductive tissues (2-3 times higher in anthers than in coleoptiles). The fact that $C E N H 3$ genes activity in sekalotriticum remains at the same level with parental species indicates that maternal cytoplasm does not affect this rate. The results obtained reflect the ability of centromeres to adapt to a new genetic environment in cells of allopolyploid hybrids.

Acknowledgements: This research was financially supported by the Russian Science Foundation (grant 19-14-00051) and the Russian Foundation for Basic Research (grant 20-04-00699 A). 


\section{Perspectives for introgression of genetic material of Mexican potato species into potato pre-breeding programs}

Gavrilenko T. ${ }^{*}$, Pendinen G. ${ }^{1}$, Antonova O. ${ }^{1}$, Makarova T. ${ }^{1}$, Thieme R. ${ }^{2}$

${ }^{1}$ Vavilov Institute of Plant Genetic Resources (VIR), St. Petersburg, Russia

${ }^{2}$ Julius Kühn-Institut, Federal Research Centre for Cultivated Plants, Quedlinburg, Germany

*email:tatjana9972@yandex.ru

Potato Solanum tuberosum is the third most important crop and the first of non-cereals, however it's production has been continually challenged by fungal, viral, bacterial diseases as well as by a lot of pests. Pesticides are widely used to protect this crop but a more attractive way is breeding resistant varieties. Wild diploid B-genome potato species native to Mexico, possess resistance to late blight, potato viruses, Colorado potato beetle, parasitic nematodes. These wild relatives belonging to the tertiary gene pool, difficult cross with $S$. tuberosum ( $2 n=4 x=48$, genome AAAA). Interspecific somatic hybrids were produced earlier via protoplast fusion of $S$. tuberosum and the selected accessions of wild diploid B-genome species $(2 n=2 x=24$, BB genome): S. bulbocastanum, S. cardiophyllum, S. tarnii, S. pinnatisectum (Thieme et al., 2008, 2010, 2016). Resistant somatic hybrids $(2 n=6 x=72$, AAAABB $)$ were consecutively backcrossed with different potato cultivars to introgress alien genetic material of the wild B-genome species into S.tuberosum genome. We studied the potential of this hybrid material as a genetic resource for potato breeding using GISH analysis and chromosome-specific SSR, STS- and CAPS markers which are polymorphic between parental genotypes.

In combination $S$. bulbocastanum (+) S. tuberosum the analyzed $\mathrm{BC}_{1}$ clones retained 912 alien chromosomes, however $\mathrm{BC}_{2}$ and $\mathrm{BC}_{3}$ hybrid clones had from 1 to 8 alien chromosomes. The success of introgressive hybridization depends largely on the potential of intergenomic recombination. $\mathrm{BC}_{1}-\mathrm{BC}_{3}$ hybrids from this combination exhibited homeologous chromosome pairing in different frequencies. Thus, intergenomic chromosome associations (bivalents, trivalents, quadrivalents) were revealed in $\mathrm{BC}_{1}$ hybrids in a frequency from 3,1 to 3,6 per cell at Metaphase I. More than two intergenomic associations exhibited $\mathrm{BC}_{3}$ hybrids having 48 chromosomes of $S$. tuberosum and from five to seven alien chromosomes. Perspectives for involvement of selected BC clones into pre-breeding programs are discussed.

Acknowledgements: The research was supported by bilateral German-Russian program, grant 131-KAD and by grant RFBR No. 20-54-00043_Bel-a. 


\title{
Automatic identification of wheat fungi diseases using a convolutional neural network
}

\author{
Genaev M.A. ${ }^{1,2,3 *}$, Skolotneva E.S. ${ }^{1,2}$, Gultyaeva E.I. ${ }^{4}$, Orlova E.A. ${ }^{5}$, Bekhtold N.P. ${ }^{5}$, \\ Afonnikov D.A. ${ }^{1,2,3}$ \\ ${ }^{1}$ Institute of Cytology and Genetics of Siberian Branch of the Russian Academy of Sciences, Novosibirsk, \\ Russia \\ ${ }^{2}$ Novosibirsk State University, Novosibirsk, Russia \\ ${ }^{3}$ Kurchatov Genomic Center of the Institute of Cytology and Genetics of Siberian Branch of the Russian \\ Academy of Sciences, Novosibirsk, Russia \\ ${ }^{4}$ All-Russian Institute of Plant Protection, St. Petersburg-Pushkin, Russia \\ ${ }^{5}$ Siberian Research Institute of Plant Production and Breeding - Branch of the Institute of Cytology and \\ Genetics of Siberian Branch of the Russian Academy of Sciences, Novosibirsk, Russia \\ *email:mag@bionet.nsc.ru
}

Diseases of cereals caused by pathogenic fungi can significantly reduce crop yields. Many cultures are exposed to them. The disease is difficult to control on a large scale, therefore, one of the relevant approaches is crop monitoring, which helps to identify the disease at an early stage and take measures to prevent its spread. One of the effective methods of control are approaches based on the identification of the disease from digital images that can be obtained by a mobile phone camera. In this paper, we present a dataset of 2414 wheat images, which represent 5 different diseases: leaf rust, powder mildew, septoria, stem rust, yellow rust. To predict the disease at early stages of development, we additionally annotated the image with the seedlings tag, if the plant corresponds to an early stage of development. Based on this dataset, we trained a model that, from a digital image of wheat plants, determines the stage of development and the type of disease. The algorithm is based on the CNN neural network of the EfficientNet-B0 architecture. The resulting model demonstrates an accuracy of 94.2\%. The WFD (wheat fungi diseases) dataset used for training is available for public access at http://wfd.sysbio.ru/. The proposed recognition model was implemented for use in the form of the @wheat_healthy_bot bot in the Telegram messenger https://t.me/wheat_healthy_bot.

Acknowledgements: Development of algorithms for wheat fungi diseases identification were funded by the Kurchatov Genomic Center of the Institute of Cytology and Genetics, SB RAS, agreement with the Ministry of Education and Science of the Russian Federation No. 075-15-2019-1662. 


\section{Marker-trait associations for barley grain quality traits identified in Karaganda and Kostanay regions using GWAS}

Genievskaya Y. ${ }^{1,2 *}$, Almerekova S. ${ }^{1}$, Abugalieva A. ${ }^{3}$, Abugalieva S. ${ }^{1}$, Turuspekov Y. ${ }^{1}$

${ }^{1}$ Institute of Plant Biology and Biotechnology, Almaty, Kazakhstan

${ }^{2}$ Al-Farabi Kazakh National University, Almaty, Kazakhstan

${ }^{3}$ Kazakh Research Institute of Agriculture and Plant Industry, Almalybak, Kazakhstan

*email: julia.genievskaya@gmail.com

Barley (Hordeum vulgare L.) is the second important cereal crop after wheat in Kazakhstan. Barley production in the country is oriented for livestock feed and brewing. Generally, the requirements for barley grain quality used in brewing and livestock feeding are different, and, usually, the good quality of the grain is associated with a lower yield. Modern genomic technologies help to identify important quantitative trait loci and determine valuable crop genotypes for breeding. Spring barley collection, including 557 USA's accessions and 104 accessions from Kazakhstan, was studied for major grain quality traits of barley grown in Karaganda (center) and Kostanay (north) regions in 2010 and 2011. The collection was previously genotyped using barley iSelect 9K SNP array resulted in 2,344 polymorphic markers. Phenotypic and genotypic data were used for the searching of marker-trait associations using GWAS. As a result, 69 marker-trait associations $(P<0.001)$ were identified for 10 grain quality traits: 13 for grain protein content, 9 for glutenin content, 9 for grain plumpness, 8 for starch content, 7 for amylose content, 7 for grain extractivity, 6 for grain glume, 5 for hordein content, 3 for albumin, and 2 for grain $\beta$-glucan content. Sixty-nine marker-trait associations were unified in 27 QTLs, considering the pleiotropic effect of several markers. Seven of these pleiotropic QTLs were previously described as associated with barley yield-related traits. Both negative and positive effects were observed for all studied traits; therefore, QTLs identified in the study may be used for the breeding of barley for different purposes and with different quality of the grain. QTLs detected in different regions of Kazakhstan have a potential usage for local barley breeding programs.

Financial support: grant AP08052804 "Development and validation of KASP arrays efficiency for key productivity and grain quality traits in two-rowed spring barley" (MES $\mathrm{RK})$. 


\section{Cas9/gRNA-mediated modifications of the barley genome for fundamental and applied research}

Gerasimova S. ${ }^{1,2}$, Egorova A. ${ }^{1,2,3}$, Hertig C. ${ }^{3}$, Korotkova A. ${ }^{1}$, Kolosovskaya E. ${ }^{2}$, Strygina K. ${ }^{4}$, Shoeva O. ${ }^{1}$, Koeppel I. ${ }^{3}$, Hiekel S. ${ }^{3}$, Vikhorev A. ${ }^{2}$, Shmakov N. ${ }^{1}$, Kochetov A. ${ }^{1}$, Kumlehn J. ${ }^{3}$, Khlestkina E.K. ${ }^{4}$

${ }^{1}$ Kurchatov Genomic Center of the Institute of Cytology and Genetics, SB RAS, Novosibirsk, Russia

${ }^{2}$ Novosibirsk State University, Novosibirsk, Russia

${ }^{3}$ Leibniz Institute of Plant Genetics and Crop Plant Research, Gatersleben, Germany

${ }^{4}$ N.I. Vavilov All-Russian Institute of Plant Genetic Resources, St. Petersburg, Russia

*email: gerson@bionet.nsc.ru

Methods of targeted genome modification provide great opportunities for reverse genetics, the generation of experimental models and trait improvement in crop plants. All these strategies have been pursued in barley research in close cooperation between the Institute of Cytology and Genetics (ICG Novosibirsk) and the Leibniz Institute of Plant Genetics and Crop Plant Research (IPK Gatersleben). The comparatively straightforward Cas9/gRNA technology allows one to knockout virtually any gene of interest. As a first concerted effort using this endonuclease platform, the NUDUM $(N U D)$ gene was knocked out in order to convert hulled into naked barley. Lines with homozygous mutations in this gene exhibit the naked grain phenotype (i.e. with nonadherent hull) and do not differ from the wild-type in any other agronomically relevant characteristics. Naked barley is an exceedingly valuable dietary component, and the exemplified principle of phenotype conversion is currently being applied for elite Siberian barley germplasm. In another line of research, several genes controlling barley grain color have been identified. To confirm their anticipated functions, barley plants carrying mutations in some of these genes were generated. As was envisaged in the experimental concepts, the obtained mutations comprised both loss-of-function and gain-of-function modifications. To establish new experimental models for basic research, some barley lines carrying homozygous mutations in unknown or poorly studied APETALA2/ETHYLENE-RESPONSIVE FACTOR (AP2/ERF) transcription factor family genes were developed. The loss-of-function of one of these genes led to a glossy leaf sheath phenotype with epicuticular wax deficiency. A comprehensive investigation of such mutants allowed us to elucidate a hitherto unknown control mechanism of epicuticular wax accumulation in barley. Taken together, the obtained results already provide an idea of the unprecedented power of Cas9/gRNA technology in crop research, the implementation of which is still in its infancy.

Acknowledgements: The study is supported by the RSF (21-66-00012) and by the Kurchatov Genomic Center of the Institute of Cytology and Genetics, SB RAS (075-152019-1662). 


\section{De novo genome sequencing, assembly, and analysis of three Russian Prunus persica varieties}

Gladysheva-Azgari M.V. ${ }^{1 *}$, Slobodova N.V. ${ }^{1}$, Boulygina E.S. ${ }^{1}$, Tsygankova S.V. ${ }^{1}$, Sharko F.S. ${ }^{1}$, Mitrofanova I.V. ${ }^{2}$

${ }^{1}$ National Research Center "Kurchatov institute", Moscow, Russia

${ }^{2}$ Nikitsky Botanical Garden - National Scientific Center of the Russian Academy of Sciences (NBG-NSC RAS), Yalta, Russia

*email: marglader@gmail.com

Common peach (Prunus persica) is an important fruit crop for domestic agriculture, new varieties of which are actively developed by breeders of the Nikitsky Botanical Garden (NBG-NSC RAS). Currently, the main task of the breeders is the creation of fruit crops varieties resistant to abiotic and biotic environmental factors. Genome decoding is an integral part of plant genetic research. The peach genome ('Lovell' variety) has recently been sequenced and annotated in very high quality. There are sequences of hundreds of peach varieties posted in the global resource, which are available to the international scientific community. However, these resources lack information on the sequencing of varieties of domestic selection and varieties from the collection of the NBG-NSC RAS. Therefore, this study is relevant both for further selection, as well as for the subsequent widespread introduction of new varieties into the horticulture of Russia. Three P. persica varieties ('Sovietskiy', 'Dostojnij', 'Babygold-7') were selected for genome sequencing, varieties 'Sovietskiy' and 'Dostojnij' were created in Russia. Each selected variety represents its own ecological-geographic group for the further possibility of finding genes responsible for important agricultural traits for different growing areas. High molecular weight DNA were isolated from the collected material (mature leaves of three $P$. persica varieties). Corresponding DNA libraries were sequenced using NovaSeq 6000 Illumina and Oxford Nanopore GridON. The obtained data were used for hybrid assemblies of three $P$. persica varieties and subsequent analysis of the resulting sequences for various mutations. Further, these genomes can be used as reference genomes for the genotyping of the entire peach collection, including the identification of target genes/loci responsible for resistance and adaptive properties in southern Russia. 


\section{Association mapping of the gene controlling melanin synthesis in barley grain using plant genetic resources collections}

Glagoleva A.Y.1*, Shoeva O.Y. ${ }^{1}$, Kovaleva O.N. ${ }^{2}$, Khlestkina E.K. ${ }^{1,2}$

${ }^{1}$ Institute of Cytology and Genetics, SB RAS, Novosibirsk, Russia

${ }^{2}$ N.I. Vavilov Research Institute of Plant Industry, St. Petersburg, Russia

*email: glagoleva@bionet.nsc.ru

Dark color of seeds is a common feature in populations of both wild (Hordeum spontaneum Koch.) and cultivated barley (Hordeum vulgare L.). The origin of dark color of seeds is believed to be a consequence of plants adaptation to unfavorable environmental conditions. It is shown that plants with a dark color of seeds are more cold and drought-tolerant, and also have increased resistance to the pathogen invasions. Such pigmentation can be due to the synthesis and accumulation of flavonoid pigments anthocyanins or melanins, which are products of enzymatic oxidation and polymerization of phenolic compounds. Unlike anthocyanins, the genetic basis of melanogenesis in plants is still a blank spot. It is known that the melanin synthesis in barley is under monogenic control of the Blp locus, located on chromosome 1HL. Recently, the locus was narrowed down to $0,8 \mathrm{Mb}$ region containing 21 predicted genes, but the particular candidate-gene is remaining undiscovered. To identify the Blp gene the association mapping approach in barley collections with black (208 samples) and uncolored (191 samples) seeds were used. To gain the enough quantity of barley samples the material of world barley collections of genetic resources from VIR and ICG was engaged. The barley collections were genotyped using the allele-specific PCR-markers, developed to polymorphic sequences in the Blp locus. As a result, the marker significantly associated with the presence of melanin was identified. The frequencies of alleles occurrence of the marker were 98,5 and 97\% in black and uncolored barley collections respectively. The presence of identified allele was confirmed by Sanger sequencing in black barleys from the different geographic regions and also in wild barley samples. It can be concluded that the melanin pigmentation has the monophyletic origin and occurred in wild barley ancestors before domestication.

Acknowledgements: The study was supported by the RFBR grant No. 20-316-90033. 


\section{The mitochondrial plasmids as a new type of mobile genetic elements in higher plants}

Gorbenko I.V. ${ }^{1 *}$, Petrushin I.S. ${ }^{2}$, Konstantinov Yu.M. ${ }^{1,2}$

${ }^{1}$ Siberian Institute of Plant Physiology and Biochemistry SB RAS, Irkutsk, Russia

${ }^{2}$ Irkutsk State University, Irkutsk, Russia

*email: gorbenko@sifibr.irk.ru

Unlike those of animals and other eukaryotes, mitochondria of many plants contain, in addition to the main high molecular weight genome, one or several types plasmids with a size ranging from 0.7 to more than $15 \mathrm{~kb}$. These mitochondrial plasmids are arranged as species-specific or line-specific sets of circular and linear molecules with unknown functions, and replicate independently of the genomic mtDNA. The mitochondrial plasmids have no sequence homology to the main mitochondrial genome and seem to be dispensable. Mitochondrial plasmid DNA may carry expressed sequences encoding proteins or transfer RNAs but until now evolutionary origin of mitochondrial plasmids is unknown. It was suggested that DNA plasmids might have been introduced into plant cells by symbionts or pathogens (Douce, Neuburger, 1989). Supporting this hypothesis, the double-strand linear plasmids with 5'-associated proteins are reminiscent of the structure of some viral genomes. It was shown that $2.3 \mathrm{~kb}$ maize linear plasmid is able to be efficiently transferred to isolated Solanum tuberosum mitochondria (Koulintchenko et al., 2003). Nowadays we have numerous evidences that plant mitochondria have special mechanisms for foreign DNA uptake, including mitochondrial plasmids (Weber-Lotfi et al., 2015; Konstantinov et al., 2016). But nothing is known whether mitochondrial plasmids are able to be transferred and incorporated into nuclear genome. It is of great scientific interest because it is well documented that genomic mtDNA is being incorporated or lost from the maize nuclear genome continuously (Lough et al., 2008). We therefore asked the question of the existence of mitochondrial plasmids DNA insertions in the nuclear genome of different lines in Zea mays. We demonstrate that 5 linear $(1.4,2.3,5.4,6.4,6.9 \mathrm{~kb})$ and 1 circular (1.9. $\mathrm{kb}$ ) maize mitochondrial plasmids have the regions of perfect homology of different length (including full-sized insertions for some of them) on all 10 chromosomes in 27 inbred lines of maize. 


\title{
Plant cell wall as a target for functional genomics
}

\author{
Gorshkova T.A. \\ Kazan Institute of Biochemistry and Biophysics FRC Kazan Scientific Center of RAS, Kazan, Russia \\ email: gorshkova@kibb.knc.ru
}

Cell wall is a remarkable structure that largely bases the peculiarities of plant biology and determines the possibilities of plant biomass application. The molecular genetic approaches to study and modify cell walls are hampered by several obstacles. Cell wall is literally and figuratively the compartment most remote from the genome. The major polymers of cell wall - polysaccharides - are formed through non-template biosynthesis by sophisticated enzymatic complexes and are subjected to various post-synthetic modifications in muro. The set of cell wall polymers and the nuances of polysaccharide structures are finely adjusted. The enzymes and proteins involved in both biosynthesis and modification are encoded by large multigene families. The number of genes that encode an enzyme to cleave one and the same bond may encounter over a hundred. Being largely non-redundant, these genes are expressed in different physiological situations, providing the unique combinations of cell wall properties in various tissues, at various developmental stages and under the influence of various stressors. To elucidate the mechanisms of cell wall development and functioning, we need to understand the specific roles of numerous molecular players, coordination between them, regulation of the process as a whole, and its combination with other cellular processes. One of the most effective approaches to advance in these directions is functional genomics. Numerous analyses of transcriptomes have been performed by us for several plant model objects including flax, maize, rye. Combined with other techniques, like advanced immunocytochemistry and determination of mechanical properties by atomic force microscopy, functional genomics helped us to characterize the cell wall processes during cellular growth, tissue specialization, signaling through oligosaccharines and lectins, development and performance of so-called "plant muscles". Cell wall happened to be a highly dynamic structure, deeply involved through various mechanisms in any change of a cell physiological status and regulating the important processes in plant development.

Acknowledgments: The work is currently supported by the grant from Russian Scientific Foundation (project No. 19-14-00361). 


\title{
Genetic transformation with $G O X$ gene from Penicillium funiculosum as a mean for the increase of potato resistance to the extremal temperatures
}

\author{
Grabelnych O.I. ${ }^{1,2 *}$, Gamburg K.Z. ${ }^{1}$, Stepanov A.V. ${ }^{1}$, Korsukova A.V. ${ }^{1}$, \\ Fedotova O.A. ${ }^{1}$, Polyakova E.A. ${ }^{1,2}$, Zabanova N.S. ${ }^{1,2}$, Borovskii G.B. ${ }^{1}$ \\ ${ }^{1}$ Siberian Institute of Plant Physiology and Biochemistry SB RAS, Irkutsk, Russia \\ ${ }^{2}$ Irkutsk State University, Irkutsk, Russia \\ *email: grolga@sifibr.irk.ru
}

It is desirable to increase potato resistance to low positive and subzero temperatures during its cultivation in zones of insecure agriculture. It is known that regulation of plant resistance to adverse environmental factors is connected with short term increase of the concentration of reactive oxygen species (ROS), which are signaling molecules for the induction of protective mechanisms. Introduction and expression of GOX gene (which encodes glucose oxidase enzyme) in plant genome induce constantly higher content of hydrogen peroxide in plant tissues and such plants may be used as a model system for the study of resistance to the extremal temperatures. Potato tubers (cv. Skarb) transformed with GOX from Penicillium funiculosum under the control of 35S RNA CaMV promoter were obtained from the Institute of Genetics and Cytology of NAS of Belarus, Minsk, Belarus. Transgenic plants of potato cultivated in vitro had high glucose oxidase activity and increased content of hydrogen peroxide compared with untransformed plants or plants transformed with the empty vector. Plantlets were treated with cold $\left(1{ }^{\circ} \mathrm{C}\right.$ for $\left.10 \mathrm{~d}\right)$ or heat $\left(50{ }^{\circ} \mathrm{C}\right.$ for $\left.1.5 \mathrm{~h}\right)$ and examined for their resistance. It was established that plantlets transformed with $G O X$ were significantly more resistant to cold treatment. However, transgenic lines were more sensitive to heat. Pretreatment with $37^{\circ} \mathrm{C}$ for $2 \mathrm{~h}$ led to total disappearance of heat sensitivity in untransformed plantlets and only partial restoration in transgenic ones. The possible biochemical mechanisms for increasing cold resistance and decreasing heat resistance of potato plants with the expressed $G O X$ gene are discussed. It is possible to suppose that the practical use of GOX gene is inappropriate. But other promoters which can increase resistance to both stresses will allow using this gene for genetic transformation of agricultural plants. 


\title{
Transcriptomic analysis of flowering-time genes in wild and cultivated chickpea
}

\author{
Gretsova M. ${ }^{1}$, Surkova S. ${ }^{1 *}$, Kanapin A. ${ }^{1}$, Samsonova A. ${ }^{1}$, Scherbakov A. ${ }^{2}$, \\ Logacheva M. ${ }^{3}$, Nuzhdin S. ${ }^{1,4}$, Samsonova M. ${ }^{1}$ \\ ${ }^{1}$ Peter the Great St. Petersburg Polytechnic University, St. Petersburg, Russia \\ ${ }^{2}$ All-Russia research Institute for Agricultural Microbiology, Pushkin, St. Petersburg, Russia \\ ${ }^{3}$ Skolkovo Institute of Science and Technology, Moscow, Russia \\ ${ }^{4}$ University of Southern California, Los Angeles, USA \\ * email: surkova_syu@spbstu.ru
}

The cultivated chickpea (Cicer arietinum L.) is a very important grain legume and a good source of plant-based protein. During domestication, chickpea was transformed from an autumn-sown crop to a spring-sown crop. Wild species, including C. reticulatum and $C$. echinospermum, possess a strong vernalization requirement. Transition from vegetative to reproductive state plays a key role for the performance of crop species. In this study, we acquired high-throughput transcriptomic sequencing data to analyze changes of gene expression during flowering transition in cultivated and wild genotypes. Gene networks involved in flowering-time control are well studied in Arabidopsis and summarized in the FLOR-ID database. We identified 274 C. arietinum coding sequences highly homologous $A$. thaliana flowering time genes. The differential gene expression was analyzed for the leaves before and after flowering initiation and for the buds at the initial stages of their formation. We considered two genotypes of wild Cicer (C. reticulatum and C. echinospermum) which meet the criteria for primary and secondary gene pools of the cultivated chickpea. $C$. arietinum genotypes included the elite early flowering cultivar ICCV96029. In our analysis we estimated (1) how flowering-time gene expression varies between wild and cultivated chickpea; (2) whether the cultivated chickpea still responds to vernalization; (3) what comprises the difference in gene expression between ICCV96029 cultivar and the other C. arietinum genotypes.

Acknowledgements: The research was funded by the Ministry of Science and Higher Education of the Russian Federation as part of World-class Research Center program: Advanced Digital Technologies (contract No. 075-15-2020-934 dated 17.11.2020). 


\title{
De novo guar genome assembly and application of "omics" technologies to speed up guar $($ Cyamopsis tetragonoloba $(\mathbf{L})$. Taub.) breeding in Russia
}

\author{
Grigoreva E.A. ${ }^{1,2,3 *}$, Tkachenko A.A. ${ }^{2}$, Ulianich P.S. ${ }^{1}$, Karzhaev D.S. ${ }^{1}$, \\ Barbitob Y.A. ${ }^{2,4}$, Changalidi A.I. ${ }^{2,4}$, Volkov V.A. ${ }^{1,3}$, Potokina E.K. ${ }^{1,3}$ \\ ${ }^{1}$ Sirius University of Science and Technology, Sochi, Russia \\ ${ }^{2}$ ITMO University, St. Petersburg, Russia \\ ${ }^{3}$ Saint-Petersburg State Forestry University, St. Petersburg, Russia \\ ${ }^{4}$ Bioinformatics Institute, St. Petersburg, Russia \\ * email: L.Grigoreva@gmail.com
}

Guar (Cyamopsis tetragonoloba (L.) Taub.) is a widely used plant mostly cultivated in India and Pakistan. Seeds of the guar is served as a rich source of galactomannan polysaccharide (guar gum) actively used in many fields of industry. The main interest in guar cultivation in Russia is supported by the high commercial value of guar gum for the oil industry. However, due to the long photoperiod typical for the most regions of Russia, guar cannot initiate flowering processes in time, which leads to a significant loss of yield. Thus, the deep understanding of genetic mechanisms underlying guar flowering processes is essential. The main problem for guar breeding is the lack of information about the guar genome. Omics technologies, combining different experimental approaches, could help to investigate important agricultural traits and, in particular, flowering processes. Here, for the first time, we present de novo guar genome assembly, constructed based on the results of short reads and long reads sequencing approaches. Genome assembly was performed by MaSuRCa assembler and contained $90.66 \%$ scaffolds with the length greater than $300 \mathrm{~Kb}$ with N50 = 2518853 b.p. This genome assembly was employed to generate genome-guided transcriptome assembly for guar and performing differential expression study between guar genotypes of different photoperiod sensitivity. For those guar genotypes results of metabolite profiling were also generated. We linked information about 1067 differentially expressed genes with concentrations of 64 metabolites and revealed that some biomarkers of early flowering in guar are linked to the specific transcripts. Besides, the created reference guar genome was used to generate a large set of SNP markers, useful for GWAS and marker-assisted breeding of the agriculturally important legume crop.

Acknowledgments: The reported study was funded by RFBR, project number 19-31651007. 


\section{SSR profiling of potato cultivars resistant to pathogens}

Gritsenko D.A. ${ }^{1,2 *}$, Aubakirova K.P. ${ }^{1}$, Pozharskiy A.S. ${ }^{1,2}$

${ }^{1}$ Institute of Plant biology and biotechnology, Almaty, Kazakhstan

${ }^{2}$ Al Farabi Kazakh National University, Almaty, Kazakhstan

*email: d.kopytina@gmail.com

Potato is among the most important vegetable crop in Kazakhstan. Genetic pool of potato consists of more than 2050 varieties, including $18 \%$ of Kazakhstani cultivars. In present study, SSR-genotyping of 42 Kazakhstani cultivars, 19 varieties of the world collection and 3 species of wild potatoes was carried out. 42 cultivars included resistant and highly resistant varieties to the late blight, early blight, potato wart and viral pathogens according to the results of field studies.

Genotyping was carried out using 24 SSR markers proposed in the new Potato genetic identity kit. The markers are evenly distributed over all potato chromosomes, every chromosome includes 2 markers with distance $10 \mathrm{cM}$ between each other. Fragment analysis was performed on Applied Biosystems 3500xL Genetic Analyzers.

Based on the results of phylogenetic analysis, a distinct cluster of Kazakhstani cultivars was determined. Polymorphic index content ranged from 0.465 to 0.875 . The least polymorphism was in the STG0025 marker; only 3 alleles were identified. The markers STG0001, STG0010, STM5114 had the highest polymorphism. As a result of the investigation, genetic profiles for 42 Kazakhstani cultivars were developed for markerassisted selection. 


\section{Identification of HMW-GS for development system evaluation bread-making qualities in early breeding generations in spring-sown triticale}

Gruzdev I.V. ${ }^{1,2 *}$, Kolenkov M.A. ${ }^{1}$, Ermolenko O.I. ${ }^{3}$, Soloviev A.A. ${ }^{1,3}$

${ }^{1}$ All-Russia Research Institute of Agricultural Biotechnology, Moscow, Russia

${ }^{2}$ Russian Timiryazev State Agrarian University, Moscow, Russia

${ }^{3}$ N.V. Tsitsin Main Botanical Garden RAS, Moscow, Russia

*email: gruzdev82mtz@mail.ru

Triticale $(\times$ Triticosecale Wittm.) has a high yield potential, as well as increased resistance to biotic and abiotic environmental factors. The technological qualities of triticale flour are largely determined by the characteristics of the storage proteins of the grain. High molecular weight glutenin submints (HMW-GS) are of particular importance among storage proteins. In wheat, the contribution of high molecular weight glutenins to bread-making quality has been studied in the most detailed way and can even be expressed in numerical points. The bread-making qualities of wheat are largely determined by the HMW-GS encoded by the Glu-Dl locus, which in hexaploid triticale is replaced by the rye Glu-Rl genome locus. The polymorphism of the Glu-RI locus in hexaploid triticale has been fairly well studied; however, the effect of the alleles of this locus on the bread-making and technological properties of triticale flour has been poorly studied. Solving this issue would allow to optimize the selection of triticale genotypes with good and excellent bread-making qualities in the early generations. The identification of HMW-GS was performed by SDS-PAGE according to Singh et al. (1991), in 36 varieties and lines of spring hexaploid triticale for which a number of indicators were previously determined that indirectly affect the baking quality. The most widespread allelic state of the Glu-Rl locus was the combination of subunits $6^{\mathrm{r}}+13^{\mathrm{r}}$; the combinations $1^{\mathrm{r}}+4^{\mathrm{r}}$ and $2^{\mathrm{r}}+6,5^{\mathrm{r}}$ are slightly less common. An average negative relationship was found between the allelic composition of the Glu-Rl locus and the indicators of grain vitreousness, gluten quality, grain unit, and 1000 grain weight. Triticale can become a valuable raw material for the bakery industry, but for this it is necessary to eliminate the objective negative influence of the rye genome.

Acknowledgments: This research was funded by the Ministry of Education and Science of Russian Federation (Goszadanie No. 0431-2019-0005). 


\section{Genetic map construction and QTL mapping of oil-related traits in sunflower from VNIIMK collection}

Gubaev R. ${ }^{1 *}$, Boldyrev S. ${ }^{1}$, Chernova A. ${ }^{1}$, Martynova E. ${ }^{1}$, Kovalenko T. ${ }^{2}$, Goryunova S. ${ }^{1}$, Goryunov D. ${ }^{1}$, Peretyagina T. ${ }^{2}$, Demurin Y. ${ }^{2}$, Khaitovich P. ${ }^{1}$

${ }^{1}$ Skolkovo Institute of Science and Technology, Moscow, Russia

${ }^{2}$ All-Russia Research Institute of Oil Crops, Krasnodar, Russia

*email: rim.gubaev@skoltech.ru

Tocopherols and oleic acid are components of sunflower oil that protect it against thermooxidation and significantly affect its quality. The tocopherol complex in plants includes four different forms, namely, $\alpha$-tocopherol, $\beta$-tocopherol, $\gamma$-tocopherol, and $\delta$ tocopherol. Importantly, vitamin $\mathrm{E}$ activity decreases from $\alpha$ - to $\delta$-tocopherol, while in vitro antioxidant activity in contrast increases in the row. On the one hand, tocopherols are the factors essential for oil rancidity resistance. On the other hand, moderate vitamin E consumption has positive effects on human health due to its antioxidant properties. Oleic acid is a monounsaturated fatty acid that in combination with tocopherols significantly increases oil thermostability. Therefore, one of the pressing tasks in sunflower breeding is the creation of plants that would allow producing oil with balanced tocopherol composition and oleic acid content. To facilitate the identification of new loci connected with these traits, we performed association mapping of quantitative trait loci (QTL) based on the high-throughput sequencing data for sunflower plants. For association mapping, two F2 populations of 144 plants each were obtained from two independent crosses of parents contrast in tocopherol composition and oleic acid content from a collection of All-Russia Research Institute of Oil Crops (VNIIMK). Tocopherol composition was measured using thin-layer chromatography while the oleic acid content was measured by means of gas chromatography followed by mass spectrometry. The genotyping-by-sequencing was performed using the Illumina HiSeq platform. The Tassel-GBS pipeline was used to find genetic polymorphisms across mapping populations. Genetic map construction and QTL mapping were performed using the R/qtl package.

Loci associated with $\alpha$-, $\gamma$-, and $\delta$-tocopherol were located on chromosome 8 while loci associated with $\beta$-tocopherol content were found on chromosomes 8 and 1. For oleic acid, a locus located on chromosome 14 was shown to be significantly associated. The QTLs and corresponding SNPs identified will facilitate the marker-assisted selection of sunflower as well as bring new knowledge on the genetic control of tocopherol composition and oleic acid content of the sunflower oil.

Acknowledgements: The reported study was funded by RFBR projects number 20-31690051 and 20-316-80002. 


\title{
Functional characteristics of EST-SSR markers in Pinus sylvestris L.
}

\author{
Gulayeva E.N.*, Tarelkina T.V., Chirva O.V., Galibina N.A. \\ Department of Multidisciplinary Scientific Research of Karelian Research Centre of the Russian Academy \\ of Sciences, Petrozavodsk, Russia \\ *email: gln7408@gmail.com
}

Pinus sylvestris L. is one of the world's most important forest-forming conifers, which is intensively used in various fields of industry. In this regard the cultivation of genetically improved artificial P. sylvestris cenoses becomes relevant. Genetic mapping, expanding research into quantitative trait loci detection, and integrating molecular genetics labeling into breeding programs will enable the development of genetically improved trees using marker assisted selection. Currently, genetic maps have been constructed for $P$. sylvestris using RAPD and AFLP markers which made it possible to identify the relationship of genes with some important agricultural traits. However, these markers are poorly reproducible and do not permit reliable loci identification. Therefore, EST-SSR markers are of particular interest. In this study, for the first time a comprehensive analysis of 102 developed or adapted for $P$. sylvestris EST-SSR markers was carried out applying bioinformatics methods. Markers alignment of $P$. sylvestris contigs / isotigs deposited in the GymnoPLAZA database allowed comparing 115 nucleotide sequences containing 70 EST-SSR markers with 55 Scots pine genes. Markers were located in different genes regions, the largest number of markers were localized in CDS and CDS / 3'UTR regions. We also identified 10 redundant pairs / triplets, derived from the same gene, among markers developed by various research teams. Functional annotations using Blast2GO made it possible to correlate $P$. sylvestris nucleotide sequences containing 59 markers $(65 \%)$ with $205 \mathrm{GO}$ annotations of different levels: biological process (62 GO terms), molecular function ( $82 \mathrm{GO}$ terms), and cellular component (61 GO terms). This analysis enabled to predict putative functions of Scots pine genes containing markers that can be associated with wood quality, cold resistance and resistance to phytopathogens. 


\title{
Genes of NBS-LRR superfamily in Solanum phureja Juz. et Buk.
}

\author{
Gurina A.A. \\ Federal Research Centre "N.I. Vavilov All-Russian Institute of Plant Genetic Resources", \\ St. Petersburg, Russia \\ email: a.gurina@vir.nw.ru
}

Nucleotide-binding site (NBS) and leucine-rich repeat (LRR) genes are a huge superfamily of genes coding for the majority of resistance genes. The most predominant disease resistance genes cloned to date are the NBS-LRR resistance genes. We decided to analyze the persistence of different NBS-LRR genes in a group of 9 samples of Solanum phureja Juz. et Buk. For research we use SRA data from NCBI (PRJNA394943 project). We use sequences of 400 known potato NBS-LRR genes and 30 genes of another species of Solanaceae for alignment. Alignment was made by Burrows-Wheeler Aligner. Further we count coverage of each position in each gene using bedtools v2.29.0. As NBS-LRR genes contain conservative domains, only high coverage of the whole gene could be evidence of gene persistence. Previously known that resistance genes in general are not found in all samples of species, and It was shown for several genes. We characterized 9 sample of Solanum phureja across the entire set of known NBS-LRR genes. 116 genes are common for all samples, include Rpi-bt1 and $R G A-2(R B)$ resistance genes from Solanum bulbocastanum Dun. Presents of other 254 genes varied between samples. Also we find homologues of $\mathrm{Mi}-1$ NBS-LRR genes of Solanum lycopersicum L. which confers isolate-specific resistance against root-knot nematodes. 60 genes are not detected among studied samples. Interesting that two of the samples (SRX4645207 and SRX4645199) strongly differ from other samples and from each other. It could be related with geographic distribution of samples, because they were collected far from other samples, but to confirm this assumption we should test more samples, which would be one of our further objectives. Also we are going to expand the set of genes on all known resistance genes of Solanaceae, it allows to find homologues of resistance genes known for other crops (for example tomato or tobacco) and use them for potato selection. Acknowledgements: This work was supported by grants from the Russian Foundation for Basic Research (Project 20-516-10001 KO_a). 


\title{
T-DNA site identification by Cas9-targeted and whole-genome Nanopore sequencing of Arabidopsis thaliana
}

\author{
Gvaramiya S. ${ }^{1 *}$, Merkulov P. ${ }^{1}$, Omarov M. ${ }^{1,2}$, Komakhin R. ${ }^{1}$, Kirov I. ${ }^{1}$ \\ ${ }^{1}$ All-Russia Research Institute of Agricultural Biotechnology, Moscow, Russia \\ ${ }^{2}$ National Research University Higher School of Economics, Moscow, Russia \\ * email: sofia.gvaramia@gmail.com
}

The identification of T-DNA insertion sites after a transformation experiment is timeconsuming and a challenging task. Traditional methods require several generations of selfing and segregation analysis followed by whole-genome sequencing. Without this information, the impact of T-DNA on phenotype can be misinterpreted. To deal with this problem, we optimized Cas9-targeted Nanopore sequencing of T-DNA insertion sites and compared this approach with the whole-genome long-read sequencing. For this, we generated transgenic $A$. thaliana plants with overexpression of GAG protein - the main component of assembling retrotransposon`s capsid. F2 plants were obtained and segregation analysis was carried out to select plant material with a single T-DNA insertion locus. With the use of CRISPR-P 2.0, we designed sgRNA for T-DNA. Synthesized sgRNAs were used for ribonucleoproteins assembly and Nanopore library preparation. The obtained reads were analysed by a newly developed pipeline and $\mathrm{T}$ DNA insertion sites were successfully determined. To verify our data, we perform whole-genome sequencing of 4 independent transgenic lines using native barcodes (EXP-NBD-104) and Ligation Sequencing Kit (SQK-LSK-109) on MinION (Oxford Nanopore Technologies, England). Approximately 400,000 reads were obtained from R10.3 flow cell with an estimated N50 23,4 kb and 10-18x coverage. With our specific bioinformatic pipeline, designed to define the insertion sites, we observed homozygous and heterozygous insertions. In addition, a plant with multiple integration events resulted in a single tandemly organized T-DNA insertion was identified. PCR was performed to confirm all T-DNA insertions. The advantages and features of Nanopore sequencing for T-DNA integration site identification will be discussed. The obtained results are useful for selection of suitable transgenic plants to study the effect of GAG protein overexpression on genome and transcriptome constitution.

Acknowledgements: The reported study was funded by RFBR, project number 20-3470032. 


\title{
Targeted mutagenesis of BRANCHED HEAD homoeoalleles causes alterations of wheat spike and root architecture
}

\author{
Hertig C. ${ }^{1 *}$, Marthe C. ${ }^{1}$, Poursarebani N. ${ }^{1}$, Budhagatapalli N. ${ }^{1}$, Hiekel S. ${ }^{1}$, Junker A. ${ }^{1}$, \\ Jacobi A. ${ }^{2}$, Schnurbusch T. ${ }^{1}$, Kumlehn J. ${ }^{1}$ \\ ${ }^{1}$ Leibniz Institute of Plant Genetics and Crop Plant Research (IPK) Gatersleben, Germany \\ ${ }^{2}$ Strube Research GmbH \& Co. KG, Söllingen, Germany \\ * email: hertig@ipk-gatersleben.de
}

The BRANCHED HEAD $(B H)$ gene of the temperate cereal wheat (Triticum aestivum L.) plays a remarkable role in the shaping of spike architecture that itself is a major determinant of the grain number produced per spike and thus of grain yield potential. By expressing specified guide RNAs (gRNA) and Cas9 endonuclease via biolistic DNA transfer to immature embryos followed by plant regeneration, suitable target motifs were addressed within the BRANCHED HEAD $(B H)$ coding sequences present in the three subgenomes of hexaploid wheat. To increase the efficiency of targeted mutagenesis, two regions conserved among the three $B H$ homeoalleles were targeted simultaneously. Mutated target motifs were observed in stably transgenic plants, but, intriguingly, also in transgene-free ones, where transient expression of gRNA and Cas 9 right after DNA transfer must have been sufficient to trigger gene-specific alterations. Target regionspecific PCR amplification and Sanger sequencing identified single, double and triple mutant plants. Additional combinations of loss-of-function homeoalleles were generated by crossing respective single mutant plants. Haploid technology was employed to generate a variety of lines with individual or combined mutant alleles being genetically fixed. A phenotypic evaluation revealed excessive formation of supernumarary spikelets as well as branching of spikes in cases of double and triple homeoallele knockout plants, which was, however, associated with a high rate of floret infertility. Astonishingly, an analysis of some single $b h$ allele knockout plants also revealed alterations in root development. Further efforts are being devoted to the development of allelic variants entailing increased grain numbers per spike while retaining high fertility. 


\title{
Regeneration capacity of potato cultivars prone to cold sweetening
}

\author{
Ibragimova S. ${ }^{1 *}$, Romanova A. ${ }^{1}$, Saboiev I. ${ }^{1}$, Salina E. ${ }^{1}$, Kochetov A. ${ }^{1,2}$ \\ ${ }^{1}$ Kurchatov Genomic Center of the Institute of Cytology and Genetics, SB RAS, Novosibirsk, Russia \\ ${ }^{2}$ Novosibirsk State University, Novosibirsk, Russia \\ *email: isola@bionet.nsc.ru
}

The regeneration of plant tissue culture technique is an essential component of biotechnological research, and required for the genetic manipulation of the plants. Only certain cultivars of tetraploid potato are amenable to transformation and others need to be test for transformation and regeneration in tissue culture. A successful and reproducible plant system requires a responsive in vitro regeneration system. Three potatoes cultivars Nikulinsky, Symphony and Nevsky (Solanum tuberosum L.) prone to cold sweetening were tests for their ability to regenerate in vitro. Stem explants was collect from in vitro grown plants. During the cultivation up to obtaining shoots, stem explants were cultivate on P1medium: MS medium, supplemented with $1 \mathrm{mg} / \mathrm{L}$ transzeatin, $0.1 \mathrm{mg} / \mathrm{L}$ IAA, $10 \mathrm{mg} / \mathrm{L} \mathrm{GA} 3$ and vitamins. Every two weeks the explants were transfer to fresh nutrient media. The time requirements for callus induction shoot regeneration and rooting was significantly induce by cultivars. Early callus initiation occurred in cv. Symphony after 6-x days cultivation, in cv. Nikulinsky and Nevsky after 35-45 days. Callus were differentiated into shoot-primordia when cultured on MS medium supplemented with the same hormones. Cultivar Symphony also showed early shoot initiation (after 15-20 days) and the mean number of shoots was higher than in other cultivars. Callus derived shoots were rooted most effectively in full-strength MS medium without hormone addition. Regenerated plants were morphologically uniform with normal leaf shape and growth pattern in all three cultivars. The full cycle of regeneration from the moment of callus to the receipt of regenerated plants of the cv. Symphony was 4 months, and cv. Nikulinsky and Nevsky - 5.5-6.0 months. Based on the data obtained, the cv. Symphony can be consider as a promising cultivar for the genetic manipulation.

Acknowledgments: The study is supported by the Kurchatov Genomic Center of the Institute of Cytology and Genetics, SB RAS (075-15-2019-1662). 


\section{Plant virus genome studies using novel databases and bioinformatics tools for text compression and entropy}

Ignatov A.N. ${ }^{1}$, Orlov Y.L. ${ }^{1,2 *}$, Luzin A.N. ${ }^{1}$, Pakina E.N. ${ }^{1}$, Dobrovolskaya O.B. ${ }^{1,3}$

${ }^{1}$ Peoples' Friendship University of Russia (RUDN University), Moscow, Russia

${ }^{2}$ Novosibirsk State University, Novosibirsk, Russia

${ }^{3}$ Institute of Cytology and Genetics, SB RAS, Novosibirsk, Russia

*email: orlov@bionet.nsc.ru

Systems biology approach for analysis of the relationship of plants, phytopathogens and other components of the pathogenesis is a challenging task. Currently, several plant viruses and bacteria are model objects in the study of various types of plant responses aimed at creating resistant plant genotypes, because the resistance of varieties is the most reliable way to reduce the harm caused by these pathogens to crop production. Important bioinformatics problems of plant virus genome organization could be solved using set of novel databases on plant virus data such as PVsiRNAdb (Plant Virus-derived small interfering RNAs database), plant RefSeq. RNA viruses face fluctuating environments and are incredibly effective at adaptation when a selective pressure is applied. Central to this adaptive capacity is the enormous genetic diversity that characterizes RNA virus populations, which is mainly due to the distinctive low fidelity of the RNA-dependent RNA polymerases of these viruses and large population sizes. Before the advent of the new generation sequencing, detection of new viruses and plant pathogenic bacteria that show latent infection was an unsolvable task. Now, it is possible to determine all possible variants of RNA transmitted inside the plant cell, which makes it possible to detect viruses that do not have clearly defined symptoms. We used bioinformatics tool Complexity for estimation of plant virus genome complexity, search for genome repeats and rearrangement sites. We estimate nucleotide and dinucleotide entropy in several classes of plant viruses in relation to adaptaion. 


\section{Intra-callus variability of Oryza sativa $\mathbf{L}$. androgenic doubled haploids}

Ilyushko M.V.*, Romashova M.V., Guchenko S.S.

Federal Research Center of Agricultural Biotechnology of the Far East named after A.K. Chaika, Ussuriysk, Russia

*email: ilyushkoiris@mail.ru

The doubled haploids (DH) approach helps in accelerating conventional plant-breeding programs. In vitro androgenesis method through callus induction is preferred in the production of rice Oryza sativa L. DHs. Callus tissue is formed through a series of mitotic divisions. The number of microspores per anther (= number of genotypes) developing into single callus has not been studied. Intracallus variability frequency of $O$. sativa DHs in vitro androgenesis was researched. Doubled haploids evolved from ten hybrid plants. Molecular genetic analysis of 855 plants obtained from 56 callus lines was performed. Presence of resistance or susceptibility alleles to five rice resistance genes to Pyricularia oryzae Cav. (Pi-1, Pi-2, Pi-ta $\left.{ }^{2}, P i-z, P i-b\right)$ was identified. Among the doubled haploids, one-three genes were detected depending on their presence in the donor hybrids. Callus lines with identical regenerants on one of the genes, as well as possessing two resistance alleles of the studied genes, were revealed. An analysis of DHs obtained from hybrids, which possess the resistance alleles of three genes, revealed no more than two combinations of alleles among the doubled haploids of single callus line out of a possible eight. With the same combination of resistance alleles of two genes, up to 28 plants were formed, and with the same combination of three genes, up to 18 plants were formed on the single callus line. Thus, low intracallus genetic variation of rice doubled haploids in androgenesis in vitro due to gametoclonal variability was revealed. A quarter $(26 \%)$ of the callus lines show variation among doubled haploids. On single callus line, one or two combinations of resistance alleles are presented. There is veritable cloning of doubled haploids within the callus lines in androgenesis in vitro, which can be used to accelerate the rice breeding process. 


\title{
Stress resistance on the example of supramolecular-genetic level of plant development
}

\author{
Ivanova E.A. \\ Ufa Institute of Biology of the Russian Academy of Sciences, UFITS UIB RAS, Moscow, st. Ufa, Russia \\ email: fiona_belobor@mail.ru
}

\begin{abstract}
Supramolecular chemistry arose as the chemistry of assemblies held together by noncovalent interactions. Through the concept of molecular recognition of the selective binding of complementary components that provide the programmed orientation of the growth and development of self-processes, she came to one of the key concepts - the concept of molecular information (passive and active), which studies the storage of information at the molecular level, as well as the reading, transmission and processing of information on supramolecular level.

Further development of supramolecular chemistry - in the direction of the general science of matter carrying information - is added, from the field of chemistry, to the fundamental triad: matter - energy - structure. Supramolecular chemistry is rapidly expanding the boundaries of chemical science to physical, biological and even sociological phenomena. Three main concepts become its foundation: fixation (binding), recognition and coordination.
\end{abstract}

The aim of the work is to present the interphase total chromatin matrix of the cell nucleus in the form of supramolecular structures: Np-nucleoplasm, Chr-I-fragile, Chr-II strongly associated with the nuclear matrix-NM and, in fact, the NM itself, on the interface of which there is a dynamic reorganization of the nuclear supermolecular proteome in a stress environment from the standpoint of epigenetic developmental biology.

The object of the study is spring wheat, bred by breeders, after a long period of cold stress, in winter. The experimental phase of ontogenesis is the initiation of growth morphogenesis. The entire experimental volume of work was carried out on patents developed in the laboratory of mathematical and molecular genetics, where the features of the isolation of cell nuclei, their supramolecular structures and elution from the latter, supermolecular blocks - non-histone and histone proteins are presented.

An algorithm for the dynamics of proteomic ensembles of supermolecular structures on the interface of supramolecular chromatin blocks is shown, on which the positioning role of $(\mathrm{H} 3+\mathrm{H} 4) "$ - arginine-rich histones in stressresistance, in the zone of meristem geomorphism of the root system of a winter cultivar, in the period of initiation of coordinated regular growth and formation of stabilization of the integrative physiological system of the regulating function of the whole organism. The presented data "from genomics to integrative physiology" lead to the concept of an epigenetic polyandrum.

Acknowledgements: The work was carried out within the framework of the state assignment of the Ministry of Education and Science of Russia No. 075-00326-19-00 on the topic No. R\&D AAAA-A18-118022190104-7. The instrument base of the Center for Collective Use "Agidel" of the UFIC RAS was used. 


\section{Production and characterization of the bread wheat lines with introgression of chromosome 6Agi2 Thynopirum intermedium}

Ivanova Yu.N.*, Stasyuk A.I., Skolotneva E.S., Silkova O.G.

Institute of Cytology and Genetics, SB RAS, Novosibirsk, Russia

*email: kabanenko@bionet.nsc.ru

Wheatgrass Thinopyrum intermedium is a source of agronomically valuable traits for common wheat. In breeding programs, partial wheat-wheatgrass amphidiploids and lines with wheatgrass chromosome substitution are widely used. The line Agis 1 (6Agi2/6D) is included in the cultivar Tulaykovskaya 10 (T10) pedigree. The wheatgrass chromosome 6Agi2 carries complex resistance to fungal diseases in various ecologicalgeographical zones and does not reduce the yield and grain quality. Varieties with 6Agi2/6D substitution are used in breeding programs. In this work, in hybrid combinations of cultivar T10 with cultivars Novosibirskaya 31 (H31) and Saratovskaya 29 (C29), plants with 6Agi2/6D chromosome substitution were isolated and their offspring were assessed for economically valuable traits. To identify chromosome 6Agi2, we used DNA markers specific to the long and short arms of this chromosome, as well as genomic in situ hybridization. Analysis of meiosis showed the cytological stability of the new forms; bivalents were formed in all meiocytes by both wheat chromosomes and wheatgrass chromosomes. According to the results of the field experiment in 2020, the samples N31xT10 and T10xS29 was characterized by high productivity traits. The mass of grains per plant and the number of grains per plant did not significantly differ from the parent varieties and the N31 variety. T10xS29 plants were characterized by the ability to tie $3.77 \pm 0.1$ grains per spike, the range of variability of the trait was from 2.93 to 4.62 in individuals. The protein content in the grain was $17.91 \%$, the gluten content was $40.55 \%$. According to the screening for fungal diseases resistance carried out in the field of 2018 and 2020, chromosome 6Agi2 preserves immunity in plants to the West Siberian population of brown rust and to dominant races of stem rust, also provides medium resistant and medium susceptible types of reaction to yellow rust.

Acknowledgements: This work was supported by the grant of the Russian Science Foundation No. 21-76-30003 and the budget project No. 0259-2021-0012. 


\title{
High-throughput application of Palindromic Sequence-Targeted (PST) PCR method for genomic fingerprinting and transposon display
}

\author{
Kalendar R.N. ${ }^{1}$, Bektayev R.T. ${ }^{2 *}$ \\ ${ }^{1}$ National Laboratory Astana, Nur-Sultan, Kazakhstan \\ ${ }^{2}$ National Center for biotechnology, Nur-Sultan, Kazakhstan \\ * email: bektayev@biocenter.kz
}

Genomic fingerprinting for various identification purposes has become a routine procedure to monitor biodiversity and control production, consumption and transportation of plants and plant-derived products. New molecular genetic methods for comparison of whole genomes or identification of selected genetic markers are continually being developed and compete with each other for their informative capacity, costs, and other properties. For this purpose, the original Palindromic SequenceTargeted (PST) PCR technique that can identify biological species in various population studies was developed. The high sensitivity and specificity of the method, provided by special thermocycling profile with the use of a combination of specially designed walking and sequence-specific primers were shown by the study results. The results allow us to propose PST-PCR as a method for gene-targeted genomic fingerprinting. It was demonstrated on the example of the Poaceae family using the VRN1 gene as a target. In this regard, multiple alignments of the $V R N 1$ gene exon 1 shows regions of varying conservation suitable for discrimination of all Poaceae species. The VRN1 gene has the potential to be a universal marker for fingerprinting of cereals and grasses. Alignment of DNA sequences of the VRN1 exons from various members of Poaceae revealed both conserved and variable regions. Primers targeting exon 1 were tested on all representatives from Phleum pratense available to the authors and universally led to amplification of the desired PCR product. DNA sequencing revealed the existence of sequence polymorphisms in the promoter and intron 1. Analysis of the molecular organization of the gene, including the lengths of the promoter and intron 1 and copynumber variation, allowed the description of polymorphisms suitable for gene-targeted genomic fingerprinting of all Poaceae species. Developed protocols may be used in the identification of lines and intraspecific and inter-species genetic variability in members of the Poaceae. 


\section{Alkaloid chemophenetics and transcriptomics of the Nicotiana genus}

Kaminski K.P., Bovet L., Laparra H., Lang G., De Palo D., Sierro N., Goepfert S., Ivanov N.V.*

PMI R\&D, Philip Morris Products S.A., Quai Jeanrenaud 5, CH-2000 Neuchatel, Switzerland

*email: nikolai.ivanov@pmi.com

In order to discover detailed alkaloid biosynthesis pathways, it is important to first determine the quantity and composition of the alkaloid pool in Nicotiana species. It is also necessary to conduct research in which accurate targeted metabolite analysis is statistically correlated with gene expression analysis.

In this study, we determined for the first time the pyridine alkaloid content (nicotine, nornicotine, anabasine, anatabine, cotinine, and myosmine) of 58 species and 2 subspecies of the Nicotiana genus by ultra-high-performance liquid chromatography coupled with mass spectrometry. We observed a clear correlation between the Noctiflorae and Suaveolentes sections and their above-average accumulation of anabasine in the genus.

We analyzed the gene expression profiles of 60 Nicotiana species by mRNA sequencing for the first time. Hierarchical clustering of alkaloid biosynthesis pathway genes and alkaloid composition revealed patterns that clearly segregated the genus sections. The correlation of gene expression with alkaloid accumulation phenotypes was evident, such as the low putrescine methyltransferase expression in all species in the Noctiflorae and Suaveolentes sections and the clear correlation of nicotine demethylase with the conversion rates of nicotine to nornicotine in the majority of species.

Several additional correlations between alkaloid accumulation and gene expression values were identified, which makes this a fundamental study for future scientific exploration of the Nicotiana genus. 


\title{
Diseases of Miscanthus rhizome: hidden threat for the development of biomass cultivations
}

\author{
Kapustyanchik S.Yu.*, Orlova E.A. \\ Siberian Research Institute of Plant Production and Breeding - Branch of the Institute of Cytology \\ and Genetics, SB RAS, Novosibirsk, Russia \\ *email: kapustyanchik@bionet.nsc.ru
}

Miscanthus is an important energy crop. Currently, Miscanthus diseases are poorly understood. phytopathological foreign studies (Central Europe, Italy) revealed the colonization of Miscanthus rhizomes by pathogenic species Fusarium, Mucor. These pathogens lead to reduced growth of underground and aboveground biomass and soil contamination. The aim of the current study was to reveal the rot of rhizomes and determine their species. Affected rhizomes selected in an experimental field with Miscanthus were used in the study. The field is located in the Novosibirsk region, Russian Federation. Rot on the rhizomes of Miscanthus were discovered as a result of field study. Extensive soft rot, accompanied by a brownish color and lack of viable roots and buds, was observed on the affected rhizomes. Cross sections of rhizomes studied. The color change affected the cortical and internal tissues of the rhizomes. Diagnostics of fungal pathogens of the affected parts of the rhizomes was carried out. Parts of the rhizomes were cut into pieces of 1-2 cm, sterilized, and placed on a nutrient substrate Czapek's medium in Petri dishes. The germinated mycelium from the part of the infected material was transferred to a clean medium for further growth. Mushrooms of the species Fusarium spp. and Mucor sp. were isolated from the affected parts of the tissues of rhizomes. Thus, pathogens colonizing rhizomes in the soil lead to a decrease in the aboveground and underground productivity of the crop. Therefore, the rhizomes for the presence of fungal infections must be assessed in order to obtain healthy planting material and its further transfer to interested parties in other regions of the country. Important for the commercialization of Miscanthus rhizomes.

Acknowledgements: This work was supported by Institute of Cytology and Genetics, SB RAS budget project No. 0259-2021-0018. 


\title{
Poplar trees expressing fungal bioluminescence system
}

\author{
Karataeva T.A*, Fakhranurova L.I., Mishin A.S., Mitiouchkina T.Y. \\ Planta LLC, Moscow, Russia \\ Shemyakin-Ovchinnikov Institute of Bioorganic Chemistry, Moscow, Russia \\ *email: karat1989@yandex.ru
}

We have recently reported the discovery of the first genetically encoded bioluminescent system from a eukaryotic organism, the fungus Neonothopanus nambi: the structure of luciferin, the luciferase and enzymes of luciferin biosynthesis. One of the precursors of the fungal luciferin (3-hydroxyhispidin) is caffeic acid, one of the most common metabolites of plants and fungi. Therefore, the bioluminescent system of fungi may integrate well into plant metabolism. This allowed us to create the first autonomously luminous plants, in which the substrate for the biosynthesis of fungal luciferin - caffeic acid - is naturally produced inside the cells. Here, we report the development of transgenic lines of poplar (Populus $\times$ canadensis) obtained by agrobacterium-mediated transformation. The bioluminescence emitted by the plants is visible to the naked eye, and the transgenic plants have a phenotype similar to wild-type plants. This suggests that the introduced system is not toxic to plants and does not affect their growth and development. These results highlight that the fungal bioluminescent system is a suitable reporter system for carrying out long-term non-invasive experiments to visualize physiological processes in a wide range of plant species. 


\title{
Employing of CRISPR/Cas9 technology to knock out genes associated with flowering in aspen
}

\author{
Karzhaev D.S. \\ Saint-Petersburg Forestry Research Institute, St. Petersburg, Russia \\ email: karzhaevd@gmail.com
}

\begin{abstract}
Populus tremula L. (aspen) is a widespread tree species that is extensively used in urban landscaping and forestry plantations due to its high growth rate. However, some undesirable traits, such as vulnerability to fungal pathogens, or the formation of "fluff", which are produced by the female trees of this species, causing allergic reactions, pose problems for the propagating of aspen. In order to improve some of the aspen disadvantages the gene-editing methods could be employed. To date, due to the risk of gene transfer from genetically edited plants to native ecosystems, these biotechnological approaches have not been widely used in forestry, and their implementation faces many limitations. To overcome these limitations and apply the gene editing techniques to woody plants, a project focusing on CRISPR/Cas9 knockout of flowering-related genes in aspen was initiated, aiming to create sterile plants. In early studies, many genes associated with flowering were identified in aspen, and further experiments were carried out to reduce the expression of these genes using RNA interference. In order to fix the sterility trait in the aspen genotype, we selected the 3 most promising genes to knockout and created sgRNA for the targets. Callus cultures of aspen will be treated with bioballistic method, the obtained regenerates will serve as a base for further gene editing experiments, focusing on manipulation of genes responsible for productivity, resistance and wood quality.
\end{abstract}




\title{
Novel method for isoform-centered analysis of alternative splicing using a combination of long and short-read sequencing data
}

\author{
Kasianov A.S. ${ }^{1 *}$, Kovtun A.S. ${ }^{2}$, Penin A.A. ${ }^{1}$ \\ ${ }^{1}$ Institute for Information Transmission Problems RAS, Moscow, Russia \\ ${ }^{2}$ Skolkovo Institute of Science and Technology, Moscow, Russia \\ * email: artem.kasianov@gmail.com
}

Recent advances in DNA sequencing technologies (single molecule sequencing platforms Pacific Biosciences and Oxford Nanopore Technologies) allow direct reading of fragments more than $1 \mathrm{~Kb}$ in length. This paves a way for the analysis of transcriptome complexity focused on isoforms, not on individual splice sites. However, the data obtained by those platforms have high error rate (substitutions, false-positive indels etc.) compared to the $2^{\text {nd }}$ generation. This adversely affects the mapping of the reads on reference genome and leads to the false identification of isoforms. Our preliminary results on the re-analysis of published data on alternative splicing using the long ONT reads show that only $5 \%$ of isoforms are congruent between multiple replicates of the same sample. This problem should be addressed by the development of new algorithms for identification and further analysis of isoforms. We developed a pipeline based on a combination of highly accurate but short reads obtained using Illumina platform and long but error-rich reads from single molecule sequencing. We tested this approach on datasets obtained from cDNA sequencing of Arabidopsis thaliana leaves and anthers on Oxford Nanopore Technologies platform. Samples were taken in two biological replicates; the use of our pipeline yielded the results that were highly congruent between replicates (more than $60 \%$ of isoforms were detected in both replicates). We also applied it to recently published data of direct RNA sequencing (Zhang et al., 2020) and performed a side-by-side comparison of our pipeline and trackcluster software (https://github.com/Runsheng/trackcluster). It showed that our pipeline outperforms trackcluster providing more accurate prediction both known and novel isoforms (approximately $80 \%$ of known isoforms and approximately $60 \%$ of novel isoforms were detected by our pipeline in both replicates versus approximately $75 \%$ of known isoforms and approximately 5\% of novel isoforms were detected by trackcluster in both replicates).

Acknowledgements: The study is supported by Russian Foundation for Basic research (project No. 18-29-13017). 


\title{
Transcriptome of the Arabidopsis thaliana Chernobyl ecotype seedlings: simulating of the space radiation action and microgravity
}

\author{
Kazakova E.A. ${ }^{1 *}$, Podlutskii M.S. ${ }^{1}$, Moiseev A.S. ${ }^{2}$, Kazakov E.I. ${ }^{2}$, Saburov V.O. ${ }^{2}$, \\ Babina D.D. ${ }^{1}$, Podobed M.Yu. ${ }^{1}$, Volkova P.Yu. ${ }^{1}$ \\ ${ }^{1}$ Russian Institute of Radiology and Agroecology, Obninsk, Russia \\ ${ }^{2}$ A. Tsyb MRRC, Obninsk, Russia \\ * email: elisabethafeb19@gmail.com
}

The problem of search for biological mechanisms of plant response to extreme space conditions, such as ionizing radiation and microgravity, is important for space biology in the aspect of long-term space missions to Mars. We exposed Arabidopsis thaliana seedlings of the Chernobyl ecotype (ChE) and wild type Col-8 to radiation combined with simulated microgravity, as well as to the microgravity and protons separately. An energy of protons was $100 \mathrm{MeV}$, for each sample the total absorbed dose was $10 \mathrm{~Gy}$, rotation speed of the 3D-clinostate was $60 \mathrm{rpm}$. The analysis of the seedlings transcriptome was performed on the Illumina NovaSeq 6000 platform; more than 990 million reads were obtained. In seedlings of the $\mathrm{ChE}$ and wild type exposed to simulated space conditions, 44 and 47 up-regulated differentially expressed genes (DEGs) $\left(\log _{2} \mathrm{FC}\right.$ $>2$, FDR adjusted $p$-value $<0.05$ ) were detected, compared with control seedlings of $\mathrm{ChE}$ and Col-8 respectively. In exposed ChE seedlings, 8 unique DEGs relatively to Col8 were identified associated with DNA repair, replication, and protein metabolism. An analysis of the functional GO enrichment for DEGs in $\mathrm{ChE}$ exposed to proton irradiation and clinostating revealed the enriched terms associated with response to ionizing radiation, DNA repair, and cell cycle; for Col-8, the terms were also associated with the same processes. At the same time, when comparing the genotypes of ChE and Col-8, 165 up-regulated and 206 down-regulated DEGs were revealed in ChE relative to Col8. The results of the work allowed us to identify and compare the most probable molecular pathways that respond to the simulated outer space conditions in the seedlings of the Chernobyl ecotype and wild type A. thaliana, which in the future will make it possible to obtain plants with increased stress resistance to space environmental conditions.

Acknowledgements: Supported by RSF (No. 20-74-00101). 


\title{
Advanced panel of molecular markers identifying of stem rust resistance genes $\mathrm{Sr} 2, \mathrm{Sr} 15, \mathrm{Sr} 21, \mathrm{Sr} 22, \mathrm{Sr} 23, \mathrm{Sr} 24, \mathrm{Sr} 25, \mathrm{Sr} 26$, Sr31, Sr35, Sr36, Sr38, Sr39, Sr45, Sr57, Lr6Ai\#2 in Siberian wheat cultivars
}

\author{
Kelbin V.N. ${ }^{1 *}$, Skolotneva E.S. ${ }^{1}$, Shamanin V.P. ${ }^{2}$, Salina E.A. ${ }^{1}$ \\ ${ }^{1}$ Institute of Cytology and Genetics, SB RAS, Novosibirsk, Russia \\ ${ }^{2}$ Omsk State Agrarian University named after P.A. Stolypin, Omsk, Russia \\ *email: kelbin@bionet.nsc.ru
}

Wheat stem rust caused by the fungus Puccinia graminis f. sp. tritici (Pgt) is a dangerous disease that has destructed the wheat crops around the world for centuries. The most effective, economical and environmentally friendly way to protect wheat from stem rust outcomes is to cultivate resistant varieties of wheat. Before this, germplasm and wild relatives assessment is required to identify resistance genes that are effective against both the local pathogen and the Ug99 race. The aim of this study was to identify genes and gene loci for resistance to wheat stem rust in Russian wheat germplasm using advanced panel of markers. The germplasm for analysis included 224 varieties and lines of wheat, the collections of which were kindly provided by: (1) FSBEI HE Omsk SAU (Omsk region) - 80 varieties / lines of spring soft wheat and 12 lines of spelt wheat; (2) FRC IC\&G SB RAS (Novosibirsk region), consisting of 132 varieties of spring soft wheat. Identification of resistance genes were carried out using the DNA-markers recommended for marker selection (MAS). Among the Omsk germplasm we observed the varieties carrying the following resistance genes: $S r 2, S r 15, S r 23, S r 24, \operatorname{Sr} 25, \operatorname{Sr} 31$, Sr38, Sr57. The genes Sr2, Sr15, Sr23, Sr24, Sr25, Sr31, Sr35, Sr39, Sr57 and Lr6Ai\#2 in various combinations were identified in the varieties of the Institute of Cytology and Genetics.

Acknowledgements: The reported study was funded by RFBR, project number 19-31690051 and the budgetary project No. 0259-2019-0001. 


\section{The instrumental cultivation of Phlojodicarpus sibiricus cell culture}

Khandy M.T. ${ }^{1,2 *}$, Sofronova A.K. ${ }^{3}$, Tomilova S.V. ${ }^{4}$, Klyushin A.G. ${ }^{4}$, Nosov A.M. ${ }^{4}$

${ }^{1}$ FSC East Asia Terrestrial Biodiversity, FER RAS, Vladivostok, Russia

${ }^{2}$ M.K. Ammosov North-Eastern Federal University, Yakutsk, Russia

${ }^{3}$ Far Eastern Federal University, Vladivostok, Russia

${ }^{4}$ K.A. Timiryazev Institute of Plant Physiology RAS, Moscow, Russia

* email: handy_89@mail.ru

In this study, the cultivation of Phlojodicarpus sibiricus cells was carried out in two types of bioreactors. The object of the study was $P$. sibiricus suspension culture. Cells were grown in MS medium with phytohormones. For the cultivation were used bioreactors with different types of stirring devices: 1) A stirring tank bioreactor, with a total volume of 7.51.2) A bubble column bioreactor, with a total volume of 211 . The air supply rate for aeration is from 0.17 to 0.251 per 11 of the culture medium per minute. The optimum planting density of the inoculum in the bioreactor for dry biomass was $1 \mathrm{~g} / \mathrm{l}$ (determined experimentally). During cultivation, the viability and growth characteristics of cell cultures were determined by dry biomass: growth index (I), specific growth rate $(\mu)$. From the results obtained, it follows that instrumental cell growth in a bubble column bioreactor leads to stable growth of the culture with a lag phase duration of about 3 days and an improvement in its main growth parameters relative to flasks $\left(\mathrm{I}=12.7 ; \mu=0.18\right.$ day $\left.^{-1}\right)$. On the contrary, when using a stirring tank bioreactor, a deterioration in growth parameters was noted $\left(I=7.6 ; \mu=0.13\right.$ day $\left.^{-1}\right)$. Growth rates decrease was obtained in the earlier works with cell cultures of other species (Dioscorea deltoidea, Panax japonicus, Stephania glabra). An improvement in growth characteristics in a bubble column bioreactor is presumably associated with an increase of cell aeration, and a deterioration in growth when using a stirring tank bioreactor - with a damaging effect on cells of stirring devices. Thus, the instrumental cultivation of the $P$. sibiricus suspension was carried out for the first time.

Acknowledgements: The results were obtained as part of the state task of the Ministry of Education and Science of Russia (FSRG-2020-0019). 


\section{Tolerance of potato cultivars to potato spindle tuber viroid PSTVd}

Khiutti A.V. ${ }^{1 *}$, Mironenko N.V. ${ }^{1}$, Lashina N.M. ${ }^{1}$, Matsushita Y. ${ }^{2}$, Afanasenko O.S. ${ }^{1}$

${ }^{1}$ All-Russian Institute of Plant Protection, St. Petersburg, Russia

${ }^{2}$ NARO, Institute of Vegetable and Floriculture Science Tsukuba, Japan

*email:alexanderkhyutti@mail.ru

Potato spindle tuber viroid (PSTVd) has a wide geographical distribution. The disease has quarantine status and is highly harmful. PSTVd infected potato plants become stunted, their leaves turn yellow, and infected tubers become small and cracked. The genotype of host and PSTVd strain affects the manifestation of symptoms. The aim of the research was to determine the tolerance of modern potato cultivars to two strains of PSTVd. Tolerance of 10 potato cultivars of Russian breeding - Aurora, Bison, Udacha, Elizabeth, Kinza, Mirage, Ariel, Sapsan, Favorite and Armada and 12 foreign cultivars - Red Scarlett, Riviera, Gala, Colomba, Lugovskoy, Odyssey, Adretta, Red Fantasy, Queen Anne, Berkut, Nazca and Mandola to strains PSTVd VP87 and VP35 has been determined. One step RT-PCR with primer set P3/P4 was used for detection PSTVd in the potato leaves. 2 months after the inoculation, the diagnostic fragments indicating the presence of the PSTVd were found in plants of all cultivars except Elizabeth, Favorite and Sapsan (data from two biological repetitions). In cultivar Elizabeth after 2.5 months of inoculation PSTVd was also not detected, but after 3.5 months, the diagnostic fragment indicating a replication of the viroid was determined. Slow, in comparison with other cultivars of viroid replication dynamics may be one of the signs of tolerance of this cultivar. A group of strongly affected varieties was distinguished, in which very bright diagnostic fragments were determined to both strains in both repetitions of the experiment, indicating a high concentration of viroid. These are cultivars Udacha, Gala, Red Scarlet, Bison, and Colombo. The symptoms of the disease on different cultivars was studied. The main symptoms were wrinkling, twisting of leaves and deformation of the leaf tip. Brightly expressed symptoms of viroid on formed tubers manifested in elongated form and deformations were noted on cultivars Udacha and Aurora.

Acknowledgements: The research was supported by a grant from the Russian Science Foundation No. 20-46-07001. The Strategic International Collaborative Research Project promoted by the Ministry of Agriculture, Forestry and Fisheries, Tokyo, Japan (No. J008837). 


\title{
The knockout of predicted MYB60 gene in Eruca sativa promotes anthocyanin accumulation
}

\author{
Khusnutdinov E., Panfilova M., Sukhareva S., Mikhaylova E.* \\ Institute of biochemistry and genetics UFRC RAS, Ufa, Russia \\ *email:mikhele@list.ru
}

Eruca sativa (E. vesicaria, rocket) is a valuable plant in the family Brassicaceae, used as a leaf vegetable. Its genome is represented only by one assembly (GCA_902460325.1) which is not annotated. The functions of E. sativa genes are not determined yet.

Transcription factor MYB60 is a well known negative regulator of anthocyanin biosynthesis in Brassicaceae, including Arabidopsis thaliana, Brassica rapa, Brassica napus, Brassica oleracea, etc. Variation in the expression level of MYB60 gene affects anthocyanin biosynthesis. Therefore mutants are visible due to increased or decreased pigmentation, which can serve as a great model system to develop transformation methods and genetic constructs. Leaf vegetables accumulating anthocyanins can become popular as a component of a healthy diet. Unfortunately, homologs of this gene and encoded protein in E. sativa have never been identified. By our experience, this species can be successfully transformed via floral dip method, just like $A$. thaliana. It makes E. sativa a noteworthy experimental object for genome editing.

gRNA spacer was selected for the most conserved region of the gene and cloned into the pDIRECT_22A vector (Addgene plasmid \# 91133). Four plants were treated with Agrobacterium tumefaciens carrying the plasmid, and 150 resultant seeds were sown. Among seedlings five putative mutants with pigmented leaves and flowers and/or decreased stem length were chosen for further analysis. Expression level of predicted MYB60 gene in two dwarf and pigmented mutants was 5 times lower than in wild type plant. Melting curve analysis revealed that both of them were probably homozygous mutants. Three putative mutants had normal stem length and 3 -fold reduction in gene expression. According to melting curve analysis, they were either heterozygous of chimeric. These results suggest that the putative homolog of MYB60 gene of E. sativa has the same functions and can be used as a target to increase anthocyanin accumulation. Acknowledgments: The reported study was funded by Russian Science Foundation according to the research project No. 20-74-10053. 


\title{
Stress immunity of CMS lines of Sorghum bicolor (L.) Moench at the basis of different cytoplasmic sterility types
}

\author{
Kibalnik O.P.*, Efremova I.G., Kukoleva S.S. \\ Russian Research Design and Technology Institute for Sorghum and Corn, Saratov, Russia \\ *email: kibalnik79@yandex.ru
}

There has been increasingly observed global changes of climatic parameter at the present moment. It prevents sustainable plant growing development (frequent drought seasons and hot winds, insufficient precipitation, air temperature variation, soil salination and acidification and etc.). Sorghum is agricultural crops, defined by higher stress immunity and fecundity. At growing kinds and hybrids highly efficient and sustainable to abiotic conditions of specific zonule, using genetically diverse source material is of fundamental importance. At development of hybrids F1 CMS - lines with different types of sterile cytoplasmic have been involved in crossing. It has been established, that plant resistance to environment external factors depends on coordinated cooperation of nuclear genome and cytoplasm. However, information on cytoplasmic effects that influence on stress immunity of CMS lines and hybrids differing just in type of sterile cytoplasm, is represented very rarely in literature. Analysis has shown that cooperation of development conditions of genotypes and cytoplasm is registered at hybrids $\mathrm{F}_{1}$ of corn, crab grass, rye. For this purpose, exploring influence of sterility types on xerophytism of CMS lines has major importance. One of the xerophytism factors is a swelling of seeds in hypertonic solutions. As hypertonic solution aiming to determining cytoplasmic effect for water consumption of CMS-lines seeds and selection of optimal osmoticum sucrose and saltpeter with osmotic pressure 19 and 72 atmosphere respectively was applied. As study object seeds of isonuclear CMS-lines with nuclear gene of yellow grain line 10 at cytoplasm A3, A4 and 9E were used, namely lines differed from each other just in CMS type. In this experiment seeds of sterile lines were obtained in different climatic parameter 2015-2017. Swelling of seeds was considered in runtime: in 1, 2, 4, 6, 24 and 48 hours, in hypertonic solutions as well as in distilled water (control). In the result of researches it has been established that the processes of income of water to sorghum seeds are defined by swelling curve with S-shaped form corresponding to many agricultural crops. In average for three years of testing, the difference between cytoplasm A3, A4 and 9E had been observed in 24-48 hours of experiment, herewith an equivalent tendency has been marked at seeds exploring, developed in 2015 and 2017. Swelling of seeds in distilled water $(54.7 \%)$ and in saltpeter $(53.4 \%)$ was higher than in sucrose $(52.9 \%)$. There are good reasons to applying cytoplasm A3 in breeding for increasing source material xerophytism: water consumption of seeds in sucrose solution is higher by $2.2-2.4 \%$, than at cytoplasm A4 and $9 \mathrm{E}$. 


\title{
Genome editing in wheat: exploration of new challenges for crop improvement
}

\author{
Kingsly J.N.B. \\ Department of Agriculture, School of Agriculture and Biosciences, Karunya Institute of Technology and \\ Sciences, Coimbatore, India \\ email: johnkingslyjk@gmail.com
}

Genome editing is one of the most efficient technique for wheat improvement. Wheat is considered as the most quotidian food for the mankind and there has been an urgent need to increase the yield of wheat in the next few years to sustain the human growing population. In the past few years, the wheat research has emphasized the fact that existing technology lacks to explain about the genetic transformation in wheat due to lack of knowledge of the genetic determinants underlying the traits that are responsible for its crop yield and quality. Recent breakthroughs in the wheat genome sequencing has provided a quantum leap in the wheat crop improvement. In this review, we outline the current progress in the genome editing for wheat crop improvement, genetic transformations, modification of the gene structures of the wheat and involvement of the expression of the site-specific nucleases in wheat for genome editing. We also explain about the new challenges that are underlying for the wheat crop improvement in exploiting the CRISPR/Cas9 complex. This review further abridges the fundamental gap enhancing the wheat yield, quality, nutritional value and resistances to various stress agents. 


\section{Breakthroughs in plant retrotranscriptome and mobilome characterization enabled by Nanopore sequencing}

Kirov I. ${ }^{1,2 *}$, Merkulov P. ${ }^{1}$, Gvaramiya S. ${ }^{1}$, Omarov M. ${ }^{1}$, Dudnikov M. ${ }^{1,2}$, Kolganova E. ${ }^{1}$, Komakhin R. ${ }^{1}$, Divashuk M. ${ }^{1,2}$, Karlov G. ${ }^{1}$, Soloviev A. ${ }^{1}$

${ }^{1}$ All-Russia Research Institute of Agricultural Biotechnology, Moscow, Russia

${ }^{2}$ Kurchatov Genomic Center of ARRIAB, All-Russia Research Institute of Agricultural Biotechnology, Moscow, Russia

*email: kirovez@gmail.com

The significant part of the vast majority of plant genomes is occupied by mobile elements including DNA transposons and retrotransposons. These elements played a crucial role in plant evolution and the breeding of new crop varieties. However, their repetitive nature challenges their investigation using 'gene-centric' bioinformatics tools remaining current mobile element activity poorly studied. To fill in this gap, we used different Nanopore sequencing approaches (direct RNA, whole-genome and Cas9-targeted sequencing) to detect ongoing transcriptional (retrotranscriptome) and transpositional (mobilome) activity of retrotransposons (RTEs). We unravelled hundreds of RTE transcripts in different plant species expressed under non-stressed and stressed conditions and in different organs and developmental stages. In most of the plant species, RTEs produced different isoforms with higher expression of GAG encoding transcripts. Using Cas9-targeted Nanopore sequencing we were able to detect tens of recent insertions in Arabidopsis thaliana population and Aegilops taushii genomes demonstrating an unprecedented level of resolution and sensitivity for mobilome studies. We found that this approach is more cost-effective compared to whole-genome Nanopore sequencing. Moreover, we designed a pipeline for easy detection of RTE and T-DNA insertions from Nanopore data. Features and further perspectives of Nanopore sequencing for plant mobilome biology studies will be discussed.

Acknowledgements: The reported study was funded by RFBR, project number 20-3470032. 


\title{
Functional characterization of genes with circadian expression patterns in common wheat
}

\author{
Kiseleva A.A.*, Bragina M.K., Salina E.A. \\ Institute of Cytology and Genetics, SB RAS, Novosibirsk, Russia \\ *email: antkiseleva@bionet.nsc.ru
}

The periodicity inherent for such factors, as light and temperature, is expressed in most physiological processes and the behavior of most living organisms. In wheat some key components of plant circadian rhythms have been identified, but there is little data on their daily expression and interaction of these genes. During the project, using the systemic analysis of the wheat transcriptome, genes expressed in the circadian type and the metabolic pathways controlled by them were identified: responses to stimuli and nutrients, transport, photoperiodism, photomorphogenesis, synthesis and degradation of different metabolites, regulation of the processes of RNA synthesis. It was shown that a significant part of the transcriptome is under the control of circadian rhythms, and the expression of these genes can vary greatly with time. We identified five expression patterns characterized by peaks at different time points and described the genes underlying these patterns. We analyzed the enrichment of gene ontology terms with various patterns and described the main metabolic pathways in each group. Transcription factor enrichment analysis of genes in different modules shown that TCP transcription factors are common regulators for the circadian genes. The specific transcription factors for every module were also detected. We identified homologues of the genes of circadian rhythms in Arabidopsis, assessed and compared the patterns of their expression. For the majority of genes, the patterns coincided, which may indicate the conservatism of genes for circadian rhythms in common wheat relative to the Arabidopsis.

Acknowledgements: The reported study was funded by RFBR, project number 20-31680003. 


\title{
An integrated approach to study genetics of Triticum aestivum vegetation period
}

\author{
Kiseleva A.A. ${ }^{1,2 *}$, Stasyuk A.I. ${ }^{1}$, Bragina M.K. ${ }^{1}$, Berezhnaya A.A. ${ }^{1,3}$, \\ Kolozhvari A.E. ${ }^{1,3}$, Leonova I.N. ${ }^{1}$, Kochetov A.V. ${ }^{1,2}$, Salina E.A. ${ }^{1,2}$ \\ ${ }^{1}$ Institute of Cytology and Genetics, SB RAS, Novosibirsk, Russia \\ ${ }^{2}$ Kurchatov Genomic Center of the Institute of Cytology and Genetics, SB RAS, Novosibirsk, Russia \\ ${ }^{3}$ Novosibirsk State University, Novosibirsk, Russia \\ * email: antkiseleva@bionet.nsc.ru
}

The vegetation period consists of two main stages - the time from seedling to heading and the time from heading to maturation. The key factors involved in the transition of a plant from the vegetative to the generative developmental phase are identified, however many components and mechanisms of this pathway are still unknown. Here, we aimed to study the different components and functioning of this path in detail. Methods of classic genetics included identification and characterization of novel alleles ( $\mathrm{Vrn}-\mathrm{B3})$ and study of the interaction between main flowering genes (Vrn-B3a, Ppd-D1, and Vrn1). Bioinformatics methods let us study wheat diurnal transcriptome to reveal components of circadian rhythms involved in the transition of plants to different developmental stages. Methods of genome editing with gRNA/Cas9 system are to study the regulation of expression of $P p d-D 1$ gene. This work is currently in progress and we guess it will result in plants with shortened flowering time. The genetics of the second part of the vegetation period (maturation time) is now poorly understood. In this work, we have shown that in the long day the vegetation period is most influenced by the period from heading to maturation, but not heading time itself. Methods of quantitative genetics (GWAS, QTL analysis) let us identify novel loci and dissect candidate genes for wheat maturation time. Thus, in this work we advanced our knowledge about genetic determinants of the first stage of the vegetation period (heading time) and identified new genetic factors influencing the second stage (maturation time).

Acknowledgements: This work was supported by the Kurchatov Genomic Center of the Institute of Cytology and Genetics, SB RAS (075-15-2019-1662). 


\title{
Gene expression stability at high evolutionary distances
}

\author{
Klepikova A.V.*, Kasianov A.S., Penin A.A. \\ ${ }^{1}$ Institute for Information Transmission Problems RAS, Moscow, Russia \\ * email: annklepikova@gmail.com
}

Stably expressed (stable) genes are the genes with approximately uniform expression level across various organs and tissues of the organism and/or different conditions. Stably expressed genes were thoroughly analyzed for a plenty of both model and nonmodel species using large-scale data including single-celled RNA-seq. The primary motivation for stable genes studies is usually the identification of reference genes for normalization of gene expression level between samples in real-time qPCR and RNAseq. On the other hand, the interesting questions are which biological functions need a uniform amount of genes mRNA in the whole organism and are the expression stability evolutionary conservative between distantly related species. To address these questions, we analyzed transcriptome maps of five plant species: Arabidopsis thaliana, Fagopyrum esculentum (buckwheat), Phalaenopsis equestris, Solanum lycopersicum (tomato), and Zea mays (maize). We found stably expressed genes for every species and studied their orthologization. Genes that were stable in all species participated in RNA splicing and modifications, membrane organization, transport and mitochondria functioning. We analyzed the regulation of stably expressed genes and identified conditions that disturb their expression level. Our results suggest an explanation of the conservativeness of gene expression stability at high evolutionary distances.

Acknowledgements: The reported study was funded by RFBR according to the research project No. 18-29-13017. 


\section{Evaluation of genetic diversity in Brassica L. species and cultivars through application of microsatellite markers}

Klimenko I.A., Dushkin V.A., Antonov A.A.*

Federal Williams Research Center of Forage Production and Agroecology, Lobnya, Russia

* email: antonov4B@yandex.ru

Genetic diversity analysis and identification of populations, lines and cultivars is an important aspect for breeding material evaluation, protection of breeder's rights and choice of promising strategies for developing samples with improved characteristics. The objective of this investigation was to study genetic variability and relationships in a collection of rapeseed (Brassica napus L.) and summer rape (Brassica rapa L.) cultivars, that were developed by breeders of Federal Williams Research Center of Forage Production and Agroecology A total of 15 rapeseed and 3 summer rape cultivars (winter and spring type) were used for DNA-polymorphisms identification with 13 microsatellite (SSR) markers, derived from data base «Brassica.info» (https://www.brassica.info). Genomic DNA was extracted using modified SDS-method from «bulk-sample» of 30 seedlings per each cultivar. The PCR reaction was performed in a total volume of $20 \mu \mathrm{l}$, containing $20 \mathrm{ng} / \mu \mathrm{l}$ of DNA according to conditions, proposed by Chandra et al. (2013). The temperature of hybridization was in range from 46 to $51{ }^{\circ} \mathrm{C}$ for each primer pairs. PCR products were separated by electrophoresis on $4 \%$ agarose gel (MetaPhor ${ }^{\mathrm{R}}$ Agarose, USA). Statistical treatment of the results was carried out using Excel Microsatellite Toolkit and PopGene software. A final set of 8 SSR primers pairs were selected from initial ones $13(61 \%)$ based on their polymorphism and repeatability. These primers produced 315 bands in the 18 samples under study (average of 17.5 bands per reaction). Size of amplified DNA fragments was in the range of 132 to $1000 \mathrm{bp}$ (Table 1). The average parameter of heterogeneity was 0.21 . Primer pairs Ni2C12, Ni03H07a Ni2C12 and Bna.M.010 were able to detect differences between cultivars of summer rape, the other ones were useful for distinguish the species and types of samples. Obtained data showed, that microsatellite markers are useful tool to find interspecies differences in Brassica genera, as well as to discriminate spring from winter types, however, additional set of markers is necessary for cultivars identification.

Table 1. Characteristics of SSR markers used for DNA-polymorphism in Brassica napus L. and Brassica rapa L. cultivars

\begin{tabular}{lcccc}
\multicolumn{1}{c}{ Marker } & Allele number & $\mathrm{He}$ & Effective number of alleles & Allele size range, bp \\
Na12A02 & 5 & 0.32 & 1.54 & $159-209$ \\
Ni2C12 & 3 & 0.13 & 1.67 & $110-140$ \\
Bna.M.009 & 5 & 0.40 & 0.40 & $165-370$ \\
Bna.M.010 & 3 & 0.19 & 1.25 & $145-173$ \\
Ni03H07a & 8 & 0.47 & 1.88 & $132-1000$ \\
NiF02a & 5 & 0.15 & 1.20 & $175-736$ \\
Ol10A03a & 8 & 0.21 & 1.29 & $166-919$ \\
Ol10F11a & 5 & 0.17 & 1.22 & $135-179$ \\
Average & 5.25 & 0.21 & 1.31 &
\end{tabular}




\title{
Study of varieties of spring triticale for the presence of the wbm gene
}

\author{
Kolenkov M. ${ }^{1 *}$, Ozherelev P. ${ }^{3}$, Gruzdev I. ${ }^{1}$, Soloviev A. ${ }^{1}$, Kirov I. ${ }^{1,2}$ \\ ${ }^{1}$ Laboratory of Marker-Assisted and Genomic Selection of Plants, All-Russia Research Institute \\ of Agricultural Biotechnology, Moscow, Russia \\ ${ }^{2}$ Kurchatov Genomic Center of ARRIAB, All-Russia Research Institute of Agricultural Biotechnology, \\ Moscow, Russia \\ ${ }^{3}$ Russian State Agrarian University - Moscow Timiryazev Agricultural Academy, Moscow, Russia \\ * email: colenckov@yandex.ru
}

Baking qualities are the most important characteristic of many main grain crops, on which the quality of future bread directly depends. The genes that determine these qualities have not yet been adequately studied, so we have an incomplete understanding of the inheritance of this characteristic and the mechanisms that lead to an increase in baking qualities. A gene called wbm (for wheat bread making) has been identified in wheat and has been shown to be expressed in increased levels in the endosperm during caryopsis development. We proved that wbm is localized on chromosome 7AL and demonstrated significant diversity in the wbm protein sequence between closely related species. The location of wbm in genome A provides an opportunity for screening a collection of hexaploid triticale lines (AABBRR, $2 n=6 x=42$ ) and allowed us to identify three triticale lines carrying this gene. These results allowed us to include the lines of spring triticale carrying the wbm gene in the scheme of breeding crosses. It is assumed that the analysis of the progeny of crosses will allow us to accurately determine the function of the wbm gene protein and determine the pattern of gene inheritance. 


\section{Optimization of cultural conditions for in vitro regeneration of wild potato species}

Koloshina K.A. ${ }^{1 *}$, Egorova A.A. ${ }^{1}$, Chalaya N.A. ${ }^{2}$, Rogozina E.V. ${ }^{2}$, Gerasimova S.V. ${ }^{1}$

${ }^{1}$ Institute of Cytology and Genetics, SB RAS, Novosibirsk, Russia

${ }^{2}$ N.I. Vavilov All-Russian Institute of Plant Genetic Resources, St. Petersburg, Russia

*email: kristina.koloshina@yandex.ru

The wild tuberous Solanum species growing in the countries of South America are a valuable donor material for cultivated potato breeding. A number of experimental approaches in wild potato biotechnology require the step of in vitro regeneration. The aim of this study was to evaluate the in vitro regeneration process of wild potato species on various culture media. The work involved 5 different protocols for callus induction (CIM) and regeneration (RM) nutrient media, and 14 wild potato samples belonging to different species from VIR Genebank collection. The stem explants were incubated at CIM until calli were formed, and then transferred to RM. The number of explants producing regenerated plants was counted. Callus formation was observed in 13 species, among them formation of regenerated plants was noted in 11 species. The samples that formed the largest number of regenerating plants belong to S.pinnatisectum, $S$. chacoence and $S$. polyadenium species. One of the experimental media was found to be suitable for the regeneration of all 11 species. This medium can further be used for different biotechnological methods, for example, for genetically modified plants regeneration after genetic transformation of potato cells.

Acknowledgements: The work was carried out with the financial support of the RFBR grant No. 20-016-00217. 


\title{
Studying the regulation of epicuticular wax biosynthesis in barley using isogenic WIN1/win1 lines generated by site-directed mutagenesis
}

\author{
Kolosovskaya E.V. ${ }^{1,2 *}$, Gerasimova S.V.1,2, Korotkova A.M. ${ }^{1}$, Hertig C. ${ }^{3}$, \\ Morozov S.V. ${ }^{4}$, Chernyak E.I. ${ }^{4}$, Domrachev D.V. ${ }^{4}$, Vikhorev A.V. ${ }^{1,2}$, Shmakov N.A. ${ }^{1}$, \\ Kochetov A.V. ${ }^{1,2}$, Kumlehn J. ${ }^{3}$, Khlestkina E.K. ${ }^{1,2,5}$ \\ ${ }^{1}$ Institute of Cytology and Genetics, SB RAS, Novosibirsk, Russia \\ ${ }^{2}$ Novosibirsk State University, Novosibirsk, Russia \\ ${ }^{3}$ Leibniz Institute of Plant Genetics and Crop Plant Research, Gatersleben, Germany \\ ${ }^{4}$ Novosibirsk Institute of Organic Chemistry, SB RAS, Novosibirsk, Russia \\ ${ }^{5}$ Vavilov Institute of Plant Genetic Resources, St. Petersburg, Russia \\ * email: kolosovskaya@bionet.nsc.ru
}

Isogenic lines with contrasting phenotypes are a perfect experimental model system for the elucidation of gene functions. The Cas9/gRNA-mediated knockout of the barley (Hordeum vulgare) WAX INDUCER 1 (HvWIN1) gene, that encodes an APETALA2/ETHYLENE-RESPONSIVE FACTOR, resulted in epicuticular wax deficiency and glossy sheath phenotype in primary mutants of cv. 'Golden Promise' and their progeny. In the M3 generation, six homozygous lines with two different mutations in the WIN1 gene were established. To assess the possible pleiotropic effects of its lossof-function, a comprehensive phenotyping of the WIN1/winl pair of isogenic lines was performed. As a result, developmental stages and major agricultural traits proved not affected by the mutation. The ultrastructure and biochemical composition of the affected wax were studied using scanning electron microscopy and gas chromatography coupled with mass spectrometry. The wax of leaf blades consists of products of an alcoholforming pathway and its amount is only slightly reduced in winl mutants. The main wax components of wild-type leaf sheaths are represented by diketones. By contrast, winl mutants accumulate a significantly lower total amount of wax on their leaf sheaths and exhibit a markedly altered wax composition; the abundance of diketones is significantly decreased, and the content of alcoholic substances is increased. A comparative transcriptome analysis of leaf blade and leaf sheath across control and mutant lines revealed strikingly different expression profiles of wax biosynthesis genes. Based on these data, it is concluded that the WIN1 transcription factor is a major and specific trigger of wax biosynthesis in leaf sheaths during generative development in barley.

Acknowledgements: The study is supported by the RSF (21-66-00012). 


\title{
The study of the wheat $P p d-D 1$ regulatory region using Cas9 RNA-directed nuclease system
}

\author{
Kolozhvari A.E. ${ }^{1,2 *}$, Kiseleva A.A. ${ }^{1}$, Salina E.A. ${ }^{1}$ \\ ${ }^{1}$ Institute of Cytology and Genetics, SB RAS, Novosibirsk, Russia \\ ${ }^{2}$ Novosibirsk State University, Novosibirsk, Russia \\ * email: a.kolozhvari@yandex.ru
}

Photoperiod sensitivity is an adaptive trait for common wheat. Correction of the photoperiod sensitivity is an important goal for modern breeding, because it result in earlier flowering. In this work, we focus on the key photoperiod sensitivity gene - PpdD1. Plant material for this project is common wheat variety Velut. Velut is high-yield and pathogen-resistant variety, but its heading time showld to be shortened. Previously, it was suggested that the modification in the paired binding sites of the transcriptional repressor CHE (CCA1 HIKING EXPEDITION) located in the promoter of the Ppd-D1 gene of common wheat would result in photoperiod insensitivity. The aim of our work was to impove the heading time of the Velut and test the hypothesis about the role of CHE binding sites in the activity of the Ppd-D1 gene. We designed and tested guide RNAs to generate three types of mutations: deletion of the long region of the promoter, deletion of a small region of the promoter involving both binding sites of the CHE, and point mutations within one of the CHE sites. We made in vitro restriction of the Ppd-DI promoter fragment using RNP (ribonucleoprotein) with different gRNAs. Densitometry analysis this digestion showed a high activity of 6 gRNAs for the large deletion, 7 gRNAs for the small deletion and 2 gRNAs within CHE sites. Currently, we are testing the activity of gRNAs on protoplasts using one pair of the most active gRNAs for each type of the mutation.

Acknowledgements: This work was supported by the Kurchatov Genomic Center of the Institute of Cytology and Genetics, SB RAS (075-15-2019-1662). 


\section{Meta-analysis of drought-induced transcriptome changes for Zea mays}

Konstantinov D.K. ${ }^{1,2 *}$, Doroshkov A.V.., 2

${ }^{1}$ Institute of Cytology and Genetics, SB RAS, Novosibirsk, Russia

${ }^{2}$ Novosibirsk State University, Novosibirsk, Russia

*email: konstantinov@bionet.nsc.ru

Motivation: One of the major limiting factors for corn (Zea mays L.) yield is drought stress, which explains a large number of studies on this issue. However, despite all efforts, the molecular mechanisms of drought response for corn and other plants hold many unknown details. Combining the results of different research teams by transcriptome meta-analysis opens a fruitful way of searching for new genes that can clarify stress response mechanisms in the post-genomic era. Moreover, analysis of a series of transcriptomic experiments improves the accuracy of revealed relationships between environmental factors and the molecular level response. In particular, a metaanalysis of several transcriptomic datasets allows to carry out a thin border between genes that stably change expression without reference to the method of experimental modeling of drought and for genes with more flexible regulation. Method and algorithm: In this work, we perform a meta-analysis for 54 Illumina-based RNA-seq datasets found via search in NCBI SRA database by the following keywords: "drought", "dehydration", and Z. mays [organism]. We used the FastQC program for analyzing the quality of the libraries, Trimmomatic for its filtering, STAR for mapping reads to a reference genome. Function featureCounts from package subread-1.6.3-source and the R package EdgeR conducted a search for the differentially expressed genes. The meta-analysis of stressinduced transcriptomes revealed 4549 genes differentially expressed in at least one considered experiment. A significant part of them demonstrated differential expression only in some experiments. Note that a part of genes had opposite direction of expression change depending on experimental conditions. This finding revealed the relationship between the method of creating stressful conditions and the activated genetic subsystems. At the same time, 167 genes changed expression in all considered experiments. Most of them were associated with processes of hormonal signaling and transcription regulation. Obtained results can be used in the development of new strategies for maize genomic selection.

Acknowledgements: This work was funded by Russian Science Foundation grant number 19-74-10037. 


\section{Targeted knockout of the NUD gene in Siberian barley}

Korotkova A.M. ${ }^{1 *}$, Kolosovskaya E.V. ${ }^{2}$, Gerasimova S.V. ${ }^{1,2}$, Hertig C. ${ }^{3}$, Otto I. ${ }^{3}$, Kumlehn J. ${ }^{3}$, Khlestkina E.K. ${ }^{4}$

${ }^{1}$ Kurchatov Genomic Center of the Institute of Cytology and Genetics, SB RAS, Novosibirsk, Russia

${ }^{2}$ Novosibirsk State University, Novosibirsk, Russia

${ }^{3}$ Leibniz Institute of Plant Genetics and Crop Plant Research (IPK) Gatersleben, Germany

${ }^{4}$ N.I. Vavilov All-Russian Institute of Plant Genetic Resources, St. Petersburg, Russia

*email: korotkova@bionet.nsc.ru

Barley (Hordeum vulgare L.) is an important food crop in the world and in Russia in particular. Naked barley provides some benefits in terms of human nutrition and health. The NUDUM (NUD) gene encodes a transcription factor involved in the formation of a lipidic layer at the grain surface of hulled barley. If the $N U D$ gene function is lost, lemma and palea do no longer adhere to the grain's pericarp, which entails the non-adherent hull (i.e. naked) phenotype. In a recent study, we obtained $n u d$ loss-of-function lines by sitedirected mutagenesis using customized RNA-guided Cas9 endonuclease in the spring barley cultivar 'Golden Promise'. It was demonstrated that the naked grain phenotype of these mutant lines is not accompanied by any modifications of agronomically relevant properties. The present investigation aims to apply the principle of converting hulled into naked barley in Siberian elite germplasm. To this end, a genetic engineering platform is being established that is applicable to a variety of genotypes including barleys from Russian breeders. As a methodical prerequisite, a panel of Russian barley cultivars was tested for the in vitro regeneration potential of immature embryo explants. The cultivars Aley, Biom and Signal performed best in this screen. Upon establishment of a protoplast transfection protocol, it was shown that mutations can be triggered in the NUD gene of $\mathrm{cv}$. Aley, thereby confirming that the used cas $9 / \mathrm{gRNA}$ vectors work effectively in this genetic background as well. Attempts to achieve site-directed mutagenesis at the wholeplant level using Agrobacterium-mediated and ballistic DNA transfer to embryo explants of cvs. Aley and Biom are in progress.

Acknowledgements: The study is supported by the Russian Science Foundation (project No. 21-66-00012) and by the Kurchatov Genomic Center of the Institute of Cytology and Genetics, SB RAS (075-15-2019-1662). 


\title{
Phenotypic characteristics of tobacco plants harboring mutations in nicotine biosynthesis genes from $P M T$ and $Q P T$ gene families
}

\author{
Kostina N.E. ${ }^{1 *}$, Lykhina A.V. ${ }^{2}$, Domrachev D.V. ${ }^{3}$, Spaselnikova A.V. ${ }^{1}$, \\ Tomilin M.A. ${ }^{1,2}$, Romanova A.V. ${ }^{1}$, Chamas S. ${ }^{4}$, Kumlehn J. ${ }^{4}$, Gerasimova S.V. ${ }^{1,2}$ \\ ${ }^{1}$ Institute of Cytology and Genetics, SB RAS, Novosibirsk, Russia \\ ${ }^{2}$ Novosibirsk State University, Novosibirsk, Russia \\ ${ }^{3}$ Institute of Organic Chemistry, Novosibirsk, Russia \\ ${ }^{4}$ Leibniz Institute of Plant Genetics and Crop Plant Research (IPK) Gatersleben, Germany \\ *email: nekostina@mail.ru
}

Nicotine accumulation is often a disadvantageous feature when using tobacco in biotechnological approaches. The decrease in nicotine levels can be achieved by knocking out respective key biosynthesis genes. In the present study, cas9/gRNA technology was used for targeted mutagenesis of the nicotine biosynthesis genes PUTRESCINE N-METHYLTRANSFERASE (PMT) and QUINOLINATE PHOSPHORIBOSYLTRANSFERASE 2(QPT2). Two genetic constructs, a vector carrying cas 9 and gRNA expression units without an antibiotic resistance gene, and a pBI121-based plasmid containing a kanamycin resistance gene and a $G U S$ reporter gene, were delivered to tobacco (Nicotiana tabacum) leaf explants using biolistic DNA transfer. The design of the cas $9 / \mathrm{gRNA}$ vector involved gRNAs simultaneously guiding the Cas9 nuclease to target motifs conserved acrossthree genes of the $P M T$ gene family and two QPT2 genes. The selection of T0 plants was carried out by application of kanamycin. In the T0 and T1 generations, plants carrying mutations in individual genes of the PMT family were identified. Five nontransgenic plants with homozygous mutations at the PMT3 gene were selected in T1 generation. The initial assessment of viability and morphology did not reveal any differences between these T1 mutant plants and their wild-type counterparts. However, the nicotine content in the leaves of PMT mutants was reduced to approximately $50 \%$ as compared to the controls. In addition, three clonally maintained T0 lines were obtained in which both QPT2 genes proved mutated. These $Q P T 2$ loss-of-function plants exhibited severe phenotypic abnormalities such as inhibited growth, a decrease in the number and size of leaves, longostyly, a decrease in pollen fertility, and the absence of viable seeds. The nicotine content in the leaves of these mutants was 6.5 times lower than the that of wild-type leaves. The severe abnormalities associated with the knockout of $Q P T 2$ suggests that these genes' function is essential also for other processes than nicotine production in N. tabacum.

Acknowledgements: The work is supported by the budget project-0259-2021-0012. 


\section{Transfer of rice resistance genes to blast using DNA markers}

Kostylev P.I. ${ }^{1 *}$, Dubina E.V. ${ }^{2}$

${ }^{1}$ FSBSI "ARC "Donskoy", Zernograd, Russia

2 FSBSI "FRC Rice", Krasnodar, Russia

*email: p-kostylev@mail.ru

Key words: rice, variety, quantitative traits, genes, markers, PCR analysis, yield, blast resistance, control nursery

Disease resistance in rice plays an important role in grain production. Since 2003, the Agrarian Research Center "Donskoy" and the Federal Research Center for Rice have been working together with the use of donors of genes for resistance to these stress factors. The studies used hybridization of the best domestic varieties with Asian samples carrying genes of interest. Samples with labeled genes were identified using PCR analysis in the splitting hybrid offspring. As a result, blast-resistant rice varieties Magnat, Pirouette, Kapitan, well adapted to local growing conditions, as well as rice samples resistant to soil salinity and deep water layers, were bred. Variety Magnat carries in its genotype the blast resistance genes Pi-1 and Pi-2, Pirouette-Pi-1, Pi-2, Pi-33, Kapitain - Pi-b, Pi-2, Argamak - Pi-1, Pi-2, Pi-33, Lenaris - Pi-ta. Lines with 5 resistance genes are also being studied. The yield of these varieties in the competitive variety testing was 8.13-9.57 $\mathrm{t} / \mathrm{ha}$, which is significantly higher than that of the standard - the Yuzhanin variety. Rice variety Argamak was bred by individual multiple selection of plants with the largest panicles from a hybrid population Il. 14 (Pi-1, Pi-2, Pi-33) $\times$ Kuboyar. The variety belongs to the mid-ripening group, the growing season from flooding to full ripeness is 119 days. On average, over the years of competitive testing (2017-2019), the yield of the variety was $8.79 \mathrm{t} / \mathrm{ha}$, which is $1.59 \mathrm{t} / \mathrm{ha}$ higher than that of variety Yuzhanin. Rice variety Lenaris had shown high adaptibility, nonlodging and possibility for straight combine harvesting. Its yield was $10.6 \mathrm{t} / \mathrm{ha}$. Plants had high spikelet fertility, short stem $(75-80 \mathrm{~cm})$, were resistant to Krasnodar population of $P$. oryzae as well. Their panicle is slightly drooping, compact, its length is $17-19 \mathrm{~cm}$. Mass of 1000 grains is about $30.4 \mathrm{~g}$.

The use of such varieties will significantly reduce the use of pesticides and reduce environmental risks. 


\title{
WOX family genes in somatic embryogenesis
}

\author{
Krasnoperova E.Y.*, Tvorogova V.E., Lutova L.A. \\ Saint-Petersburg State University, St. Petersburg, Russia \\ *email: eliz.krasnoperova@gmail.com
}

Somatic embryogenesis is one of the plant regeneration ways. In this process embryos are formed not from generative, but from vegetative tissues. It is widely used in biotechnology for plant transformation. The genes, participating in this process, usually also function in the zygotic embryogenesis. The homeodomain-containing transcription factors of the WOX family are important regulators of plant development, including both the somatic and zygotic embryogenesis. In our study the participation of the Medicago truncatula MtWOX9-1 gene in somatic embryogenesis was shown. Its overexpression leads to a significant increase of somatic embryogenesis capacity of callus tissue and to changes in expression levels of a number of genes, involved in somatic embryogenesis. The aim of this study is to analyse the interaction of MtWOX9-1 products with other genes, associated with somatic embryogenesis. Also, transcription factors from WOX family were shown to regulate expression of CLE family genes. We supposed that $M t C L E 6$ and $M t C L E 18$ genes can also be directly regulated by MtWOX9-1 transcription factor, because, according to the results of transcriptomic analysis, overexpression of MtWOX9-1 changes the expression of these genes. We use the ChIP-Seq and EMSA method to check this hypothesis.

Along with WOX9, WOX2 in A. thaliana is known to regulate zygotic embryogenesis. We found an elevation in the level of expression of its ortholog, MtWOX2, during somatic embryogenesis. Moreover, some calli with MtWOX2 overexpression are characterised by increased weight and due to this, increased amount of somatic embryos. Now we are carrying out a transcriptome analysis of calli with overexpression of this gene. Acknowledgements: The research was supported by the RFBR (20-016-00124). 


\section{Analysis of the activity of the $D R 5$ promoter in tuber-forming plants}

Kriukova K.I. ${ }^{1 *}$, Gancheva M.S. ${ }^{1,2}$, Lutova L.A. ${ }^{1}$

${ }^{1}$ Saint-Petersburg State University, St. Petersburg, Russia

${ }^{2}$ All-Russia Research Institute for Agricultural Microbiology, St. Petersburg, Russia

*email: karinkakriukova@gmail.com

Auxin is a key regulator of plant growth and development, and the synthetic auxinsensitive DR5 promoter is often used for study auxin distribution. Several tuber-forming plants were selected to analyze the activity of the DR5 promoter: Oxalis tuberosa Mol., Stachys sieboldii Mig., Apios americana Medik, Cyperus esculentus L., Solanum phureja Juz. et Buk. Different methods for sterilization of explants were tested. We also began to work out the agrobacterial transformation of plants. We have successfully introduced all of the above plants into in vitro culture. Transgenic roots of Oxalis tuberosa, Stachys sieboldii, and Solanum phureja were obtained - the activity of the $D R 5$ promoter in these plants was found at the root tip.

Acknowledgements: The work was made with support of the Ministry of Science and Higher Education of the Russian Federation in accordance with agreement No. 075-152020-922 date 16.11.2020 on providing a grant in the form of subsidies from the Federal budget of Russian Federation. The grant was provided for state support for the creation and development of a World-class Scientific Center "Agrotechnologies for the Future". 


\title{
Forest genomics: main achievements and future prospects
}

\author{
Krutovsky K.V.1, 2, 3,4 \\ ${ }^{1}$ Department of Forest Genetics and Forest Tree Breeding, Georg-August University of Göttingen, \\ Göttingen, Germany \\ ${ }^{2}$ Laboratory of Population Genetics, N.I. Vavilov Institute of General Genetics, Russian Academy \\ of Sciences, Moscow, Russia \\ ${ }^{3}$ Laboratory of Forest Genomics, Genome Research and Education Center, Siberian Federal University, \\ Krasnoyarsk, Russia \\ ${ }^{4}$ Department of Ecosystem Science and Management, Texas A\&M University, College Station, USA \\ email: konstantin.krutovsky@forst.uni-goettingen.de
}

Forest trees are the keystone species in boreal and temperate ecosystems providing numerous ecosystem services. Together with fungi they play very important role in carbon cycle and global climate control. Their economic value is also enormous. Therefore, forest genomics develops really fast, but not as fast as needed and as for other plant species. Meanwhile, the forest genetics, tree improvement and protection can greatly benefit from complete genome sequence data made recently available for several major forest tree species. They allow to identify and annotate genes, other functional elements (sRNA, transcription sites and factors, regulatory elements, etc.), and genetic networks that control adaptation and disease resistance. They can be used to develop highly informative genetic markers that can be applied in population genetic studies to create database of barcodes for individual populations to fight illegal timber harvest and trade. They are very much needed for development of genome-wide genetic markers for association studies for linking genetic variation (SNPs, alleles, haplotypes, and genotypes) with environmental factors, adaptive traits and phenotypes for better understanding genetic control of agronomically and economically important traits. They can be also used to develop genome-wide genetic markers for genomic-assisted selection to breed for better adapted, stress resistant and climate change resilient trees with desirable quality ecological and economic traits. Finally, whole genome sequences allow to integrate proteomics, transcriptomics, and metabolomics and provide reference genomes for resequencing.

All these will be demonstrated using the whole genome data obtained in several recent major research projects including the "Genomics of the key boreal forest conifer species and their major phytopathogens in the Russian Federation" project funded by the Government of the Russian Federation (grant No. 14.Y26.31.0004). 


\section{Investigation of SWEET family sugar transporter genes and their role in arbuscular mycorrhiza}

Kryukov A.A. ${ }^{1 *}$, Gorbunova A.O. ${ }^{1,2}$, Mikhaylova Yu.V. ${ }^{3}$, Yurkov A.P. ${ }^{1}$

${ }^{1}$ All-Russia Research Institute for Agricultural Microbiology, St. Petersburg, Russia

${ }^{2}$ St. Petersburg State University, St. Petersburg, Russia

${ }^{3}$ Komarov Botanical Institute, St. Petersburg, Russia

*email: rainniar@rambler.ru

Arbuscular mycorrhiza fungi (AMF) form a symbiosis with most of terrestrial plants and hence enhance plant nutrition, increase adaptation to drought and salinity. We have previously developed a unique model system "plant-host - AMF". The system includes the highly responsive to inoculation with AMF an obligatory mycotrophic plant Medicago lupulina line MIS-1, and the highly effective AMF strain Rhizophagus irregularis RCAM00320. We studied the expression of 10 genes from the SWEET family during the formation of symbiosis between M. lupulina and R. irregularis, as well as mycorrhization, symbiotic efficiency and plant productivity. We accessed gene expression at different developmental phases of host plant under low phosphorus level in a substrate. Primer for genes were developed using M. lupulina transcriptome. The occurrence of mycorrhizal infection, intensity of mycorrhization, and the abundance of arbuscules in roots increased during plant development up to the inflorescence phase. A slight decrease in the abundance of arbuscules was observed on days 27 and 33 after planting, followed by an increase starting from a day 47 . The roots/shoots ratio of M. lupulina was lower in mycorrhized plants than in plants without mycorrhiza. An inoculation of M. lupulina with the AMF increased the productivity of aboveground biomass and accelerated plant development under low phosphorus level. Gene expression analysis suggests that genes MISWEET1 $a$ and MISWEETIb are candidates for specific expression in the leaves of the mycorrhized host plant, MISWEETIa and $M I S W E E T 2 c$ are candidate genes for specific expression in the roots. Further experiments under medium and high phosphorus levels can confirm or reject this hypothesis (with an increase in minerals available for nutrition in the soil, in particular phosphorus, the expression of specific genes may decrease). The study of plantmicrobial systems will contribute to their practical implementation in the agriculture of the Russian Federation.

Acknowledgements: This work was supported by the RFBR 20-016-00245 and partially 19-29-05275. 


\title{
Comparative characteristics of barley hybrids by the anthocyanins content in grain
}

\author{
Kukoeva T.V. ${ }^{1}$, Glagoleva A.Y. ${ }^{1}$, Shoeva O.Y. ${ }^{1}$, Grigoriev Y.N. ${ }^{1}$, Strygina K.V. ${ }^{2}$, \\ Khlestkina E.K. ${ }^{1,2}$ \\ ${ }^{1}$ Institute of Cytology and Genetics, SB RAS, Novosibirsk, Russia \\ ${ }^{2}$ N.I. Vavilov All-Russian Research Institute of Plant Genetic Resources (VIR), Saint-Petersburg, Russia \\ * email: kukoeva@bionet.ru
}

Barley (Hordeum vulgare L.) is one of the most important crop for food industry. To date, the improvement of grain crops nutritional value by the biologically active compounds - anthocyanins, is a worldwide tendency. Therefore, the need to develop an initial selection material for subsequent obtaining barley varieties with an increased anthocyanins content is becoming more tangible. In barley, these compounds can accumulate in the pericarp, where their biosynthesis is controlled by complementary genes $H v A n t 1$ and $H v A n t 2$ mapped to the chromosomes $7 \mathrm{H}$ and $2 \mathrm{H}$, respectively, and/or in the aleurone layer, controlling by the $H v M y c 2$ gene located on the chromosome $4 \mathrm{H}$. In this work, using the marker-assisted selection, the barley hybrid lines carrying $H v A n t 1, H v A n t 2$ and $H v M y c 2$ genes, based on Siberian barley varieties Aley, Tanay and Vorsinsky 2 were obtained. The near-isogenic barley lines (NILs): PLP (purple lemma and pericarp, carrying Antl and Ant 2 genes) and BA (blue aleurone, carrying $H v M y c 2$ gene) from NordGen (www.nordgen.org) were used as donors. The selection of homozygous plants from the $\mathrm{F}_{2}$ populations was carried out with the intragenic PCRand CAPS-markers. From the selected plants nine hybrids of $F_{2}$ generation with the following phenotypes were taken for lines development: three hybrids with purple pericarp and hulled grain, three hulled and three naked hybrids with blue aleurone. To date, the $\mathrm{F}_{8}$ generation of selected plants was obtained. The quantitative spectrometric analysis of anthocyanins content in the whole grain showed that the most obtained hybrids have a significantly increased anthocyanin content in grain in compare with parental NILs. In hybrids obtained by the BA x Tanay crossing the anthocyanin content was in three times higher than in BA line. Thus, the developed lines are an appropriate material for further selection of barley varieties enriched with anthocyanins.

Acknowledgments: The study was supported by the RFBR grant No. 19-016-00140. 


\title{
Comprehensive analysis of Pisum sativum (L.) microRNAs
}

\author{
Kulaeva O.A. ${ }^{1 *}$, Zorin E.A. ${ }^{1}$, Romanyuk D.A. ${ }^{1}$, Gribchenko E.S. ${ }^{1}$, Afonin A.M. ${ }^{1}$, \\ Gordon M.L. ${ }^{1}$, Shtark O.Y. ${ }^{1}$, Tikhonovich I.A. ${ }^{1,2}$, Zhukov V.A. ${ }^{1}$ \\ ${ }^{1}$ All-Russia Research Institute for Agricultural Microbiology, St. Petersburg, Russia \\ ${ }^{2}$ Saint-Petersburg State University, St. Petersburg, Russia \\ *email: okulaeva@arriam.ru
}

Various processes of plant development, biotic and abiotic interactions occur with participation of different regulators, one of the main ones are microRNAs. To date, there is very small information in literature about microRNAs of garden pea (Pisum sativum L.) which among the valuable pulse crops all over the world. To increase information about pea microRNAs, Next Generation Sequencing (NGS) technologies were used. As a result, sets of microRNAs from lower and upper parts of plants were identified and annotated. Analysis of degradome sequencing, which made it possible to identify cleavage sites in transcripts, revealed targets of these microRNAs. For some transcripts, regulation by more than one miRNA has been shown and some miRNAs are involved in the regulation of several transcripts. Then searching for microRNAs which can be used like reference genes was done. The analysis was carried out on plants grown under conditions of legume-rhizobia and mycorrhizal symbiosis. The effect of cadmium was also investigated. Analysis of set of microRNAs made by Real Time PCR (RT PCR) allowed to identify several microRNAs with stable expression level, as for all conditions and for different interaction processes separately. These microRNAs can be considered as reference sequences for the further study of expression by RT PCR. At the final stage of the work expression analysis of pea microRNAs was done by NGS and RT PCR. Certain pea microRNAs were shown to be involved in the processes of legume-rhizobia symbiosis, arbuscular mycorrhiza development and processes of plant adaptation to cadmium.

Acknowledgements: This work was supported by RFBR grant No. 20-04-01136 and by RFBR grant No. 19-316-90058. 


\title{
Gradient of the rhizosphere bioelectric potentials as a source of green energy
}

\author{
Kuleshova T.E. ${ }^{1,2 *}$, Gall N.R. ${ }^{1}$, Galushko A.S. ${ }^{2}$, Udalova O.R. ${ }^{2}$, Panova G.G. ${ }^{2}$ \\ ${ }^{1}$ Ioffe Institute, St. Petersburg, Russia \\ ${ }^{2}$ Agrophysical Research Institute, St. Petersburg, Russia \\ * email: www.piter.ru@bk.ru
}

Bioelectric potentials (BEP) generated during the life of plants along the root system can become the basis for a new green energy resource. The aim of this work was to determine the gradient of bioelectric potentials generated in the root zone and to develop a construction of a plant fuel cell. Leningradsky spring barley (Hordeum vulgare L.) was chosen to study the potential gradient in the soil. Porous corrosion-resistant electrodes were placed horizontally with a pitch of $50 \mathrm{~mm}$ in the $400 \mathrm{~mm}$ high chamber for growing, and registration of the potential difference was carried out automatically every 15 minutes during the entire barley growing period. The potential difference in soil decreased from $220 \mathrm{mV}$ to $10 \mathrm{mV}$ with decrease in the interelectrode distance and drops to zero in about 20 days. The BEP increase up to $300 \mathrm{mV}$ has been observed on the $35^{\text {th }}$ day of vegetation, as the root system grows along the electrodes. It could be assumed that the root system increased the intensity of physicochemical and biological processes associated with ion transport in the rhizosphere. Soil-free type of a plant fuel cell was constructed where the electrodes were placed in the position with the observed maximum potential difference - between the root collar and the tips. Lettuce (Lactuca sativa L.) cultivated by the panoponics method was the object of research. A similar dynamics of the BEP in different variants was observed - the generation of $30-100 \mathrm{mV}$ voltage at the beginning, gradual decrease on the 5 th day of vegetation, smooth increase on the 10th day and then stabilization. The power removed from the cell was $0.04 \mu \mathrm{W}$ at a load of $10 \mathrm{kOm}$. Thus, the electrogenic properties of the plant and the oxidation-reduction reactions accompanying the life of plants in the root environment can be considered as an independent source of energy, the generation of which is carried out throughout the entire growing season. 


\section{Site-specific genetic engineering in cereals - principles and applications}

Kumlehn J.

Leibniz Institute of Plant Genetics and Crop Plant Research (IPK) Gatersleben, Germany email: kumlehn@ipk-gatersleben.de

Methods of site-directed genome modification offer great opportunities for fundamental plant research and crop improvement. As a precondition for keeping pace with the rapid development of CRISPR-associated (Cas) endonuclease technology, a modular and versatile vector system has been developed that is based upon the use of type IIS restriction enzymes and hence allows for complex molecular cloning procedures in single reactions. Not only can multiple guide RNAs be expressed simultaneously, also newly emerging system components such as Cas derivatives with improved or novel functionality can be readily tested and utilized. The increasing interest in customizable endonuclease technology is also associated with a renaissance of protoplast culture and transfection, which is of great utility for the development of novel methodical approaches as well as for the functional validation of components before it comes to the typically more laborious targeted genetic modification at the whole-plant level. In addition, options to couple site-directed genetic engineering with haploid technology have been implemented, be it for an efficient genetic fixation of modified alleles or for the use of cas $9 / \mathrm{gRNA}$-transgenic haploidy inducer lines for cross-pollination, which has the capability of triggering target site-specific modifications with much reduced genotype dependence. Cas endonuclease technology has been developed and utilized in cereals to elucidate gene functions and to improve plant performance. Recent results of translational research include the establishment of plant resistance to pathogens and the modification of further yield- and quality-determining plant features. However, a major challenge we are still facing is to establish viable techniques enabling us to generate user-preferred DNA modifications with absolute precision. 


\section{Resistance of common spring wheat genotypes to abiotic and biotic stresses in the Southern Urals}

Kushnirenko I.Yu.*, Shreyder E.R., Bondarenko N.P.

Chelyabinsk Scientific Research Institute of Agriculture, Timiryazevsky, Russia

*email: ikush2001@mail.ru

Creation of genotypes with complex resistance to extreme environmental conditions, primarily to hydrothermal stresses and fungi diseases, is the main directions of the breeding program in Chelyabinsk Scientific Research Institute of Agriculture. The combination of alternative traits such as tolerance to drought and resistance to excessive moisture exceeding optimal norms is a one of methodological task. Long-term studies have shown that, while maintaining sensitivity to drought in a variety, nonspecific resistance to carbohydrate-protein depletion of seeds, lodging, and damage by rust species is induced. Long-term studies have shown that nonspecific resistance to carbohydrate-protein depletion of seeds, lodging and damage by rust species is induced in varieties sensitive to drought.

The cultivar Erythrospermum 59, that has a unique combination of drought tolerance with resistance to excessive moisture is the sample of optimal ecotype of spring wheat for conditions of Southern Urals. Its use as a source of high plasticity provides promising breeding material and more modern commercial varieties Duet, Chelyaba stepnaya, Chelyaba jubilee.

The use of the intraspecific genetic potential of common wheat does not provide a sufficient level of protection from leaf rust. In this case the new sources of resistance carrying foreign gene translocations from Secale sereale, Aegilops speltoides, Agropyron elongatum, Agropyron intermedium, Aegilops tauschii, Triticum ventricosum are involved in breeding programs. As a result, a series of varieties with leaf rust gene LrSp from Aegilops speltoides were created (Chelyaba 75, Chelyaba 80, Odintsovskaya, Ilmenskaya) was introduced. Using effective combination of Lr-genes that have lost their efficiency in the region, the variety Silach was created. Its high resistance to the South Ural population of Puccinia triticina is controlled by a combination of genes Lr10, Lr19 and Lr26. Monitoring of the racial composition and virulence of the regional population of leaf rust pathogen is carried out for successful breeding.

Along with these varieties, a promising selection of spring wheat has been created, combining resistance to abiotic stresses with resistance to leaf and stem rust and blotches. Using molecular markers, it was shown that the resistance genes in these lines differ from the known effective ones, transferred from alien species. The most promising lines are planned to be transferred to the State Variety Testing. The influence of promising spring wheat lines bearing alien translocations on the variability of pathogen populations by virulence was not observed, which will contribute to the stability of the genetic protection in the conditions of the Southern Urals.

Acknowledgements: The current research was supported by RFBR grant No. 19-01600052. 


\section{Complex resistance of spring bread wheat lines to biotic and abiotic stress}

Lapochkina I. ${ }^{1 *}$, Gainullin N. ${ }^{1}$, Baranova O. ${ }^{2}$, Kovalenko N. ${ }^{2}$, Marchenkova L. ${ }^{1}$

${ }^{1}$ Federal Research Center "Nemchinovka", Odinzovo, Russia

${ }^{2}$ All-Russian Institute for Plant Protection, St. Petersburg-Pushkin, Russia

*email: inna-lapochkina@yandex.ru

The original initial material of spring bread wheat with group resistance to stem and leaf rust was developed using new sources of stem rust resistance: winter common wheat GT 96/90 (Bulgaria) and line 119/4-06rw with genetic material, respectively, of T. migushovae and (Ae. speltoides and S. cereale), spring wheat line 113/00i-4 obtained using the species Ae. triuncialis and T. kiharae, as well as spring accession 145/00i with genetic material of Ae. speltoides. The transfer of effective $\mathrm{Sr}$ genes to progeny was monitored using molecular markers. The new lines underwent a field assessment of resistance to leaf and stem rust in the epiphytotic development of diseases in the Central region of the RF, as well as in the North Caucasus and Western Siberia and showed high resistance to these pathogens with different racial composition. Eleven genotypes with group resistance to these diseases and the parental forms that took part in the origin of the lines were assessed for resistance to spot blotch (Cochliobolus sativus) and tan spot (Pyrenophora tritici-repentis) using isolates from Kazakhstan and Omsk under laboratory conditions. Highly resistant parental form of winter bread wheat from the collection "Arsenal" 119/4-06rw (wheat-Ae. speltoides-rye hybrid $2 n=42$ ) was isolated simultaneously to two spots and four medium-resistant genotypes to both populations of tan spot (Kazakhstan and Omsk), as well as genotypes resistant to the Omsk population of $P$. tritici-repentis (parental form 113/00i-4 and lines 1-16i, 6-16i, 9-16i). In addition, the stress resistance of lines in laboratory conditions at the early stages of ontogenesis to $\mathrm{NaCl}$ salinity and prolonged flooding of seeds with water was assessed. Lines 33-16i, 37-16i, 32-16i and 9-16i showed a high ability to withstand excess moisture. Lines 33$16 i, 37-16 i, 32-16 i$ and 3-16i were characterized by high salt tolerance, exceeding the average value of $49.7 \%$. The listed samples are of interest as sources of anaerobic and salt stress, as well as donors of resistance to a group of fungal diseases: leaf and stem rust and tan spot. We associate the increased level of resistance of the new initial material with the presence of alien translocations in the original parental forms that participated in the origin of the lines. 


\title{
Microsatellite markers for regional differentiation of Puccinia graminis f. sp. tritici populations
}

\author{
Laprina Yu.V. ${ }^{*}$, Kelbin V.N. ${ }^{1}$, Skolotneva E.S. ${ }^{1}$, Kolomiets T.M. ${ }^{2}$, Kiseleva M.I. ${ }^{2}$, \\ Baranova O.A. ${ }^{3}$ \\ ${ }^{1}$ Institute of Cytology and Genetics, SB RAS, Novosibirsk, Russia \\ ${ }^{2}$ All-Russian Research Institute of Phytopathology, Moscow, Russia \\ ${ }^{3}$ All-Russian Institute of Plant Protection, St. Petersburg-Pushkin, Russia \\ *email: i.laprina@g.nsu.ru
}

The fungus Puccinia graminis f. sp. tritici (Pgt), which causes a devastating wheat disease, is airborne and spreads easily throughout the country. The high genetic plasticity of genome serves to increase the virulence of the stem rust population and overcome the resistant genes of the host plant. Genotyping of $P g t$ isolates can be a quick method to cover a larger sample. The aim of this study is to identify polymorphic microsatellite markers (SSRs, simple sequenced repeats) that differentiate regional Pgt populations. Sixteen SSR markers were screened against $P g t$ samples from non-black earth (NBE) and black earth (BE) areas of Russia. The amplicons were polymorphic, with 1-6 alleles for each marker, and a total of 56 alleles was found: 28 within the NBE sample and 28 within the BE sample. High level of heterozygosity were observed in both populations which could be a result of sexual reproduction. Five microsatellite loci (Pgestssr059, PgtCAA80, Pgestssr293, Pgestssr325, Pgestssr318) were useful to track the origin of Pgt isolates. The NBE sample is characterized by two Pgestssr059 alleles (210 and 228 bp) in a heterozygous state; PgtCAA80 allele of 189 bp; Pgestssr293 allele of $257 \mathrm{bp}$ in a homozygous state; Pgestssr325 allele of $259 \mathrm{bp}$ in a homozygous state. The BE sample is characterized by Pgestssr059 allele of 231 bp in a homozygous state; two Pgestssr293 alleles $(266,269$ bp) in a heterozygous state; two Pgestssr325 (247, 256 bp) in a heterozygous state; Pgestssr318 allele of $207 \mathrm{bp}$.

Acknowledgements: The study was funded by the budgetary project of ICG SB RAS No. 0259-2019-0001, RFBR grant No. 18-016-00170a, the budgetary project of ARRIP No. 0598-2019-0001. 


\title{
Development and validation of molecular markers linked to locus on chromosome $3 \mathrm{H}$ conferring barley resistance to Pyrenophora teres f.teres
}

\author{
Lashina N.M. ${ }^{*}$, Rozanova I.V. ${ }^{2,3}$, Novokazi F. ${ }^{4}$, Baranova O.A. ${ }^{1}$, Mironenko N.V. ${ }^{1}$, \\ Zubkovich A.A. ${ }^{5}$, Afanasenko O.S. ${ }^{1}$ \\ ${ }^{1}$ All-Russian Institute of Plant Protection, St. Petersburg, Russia \\ ${ }^{2}$ N.I. Vavilov Institute of Plant Genetic Resources, St. Petersburg, Russia \\ ${ }^{3}$ Institute of Cytology and Genetics, SB RAS, Novosibirsk, Russia \\ ${ }^{4}$ Institute for Resistance Research and Stress Tolerance, Julius Kuehn-Institute, Quedlinburg, Germany \\ ${ }^{5}$ Republican unitary enterprise "Research and Practical Center of National Academy of Sciences of the \\ Republic of Belarus for Arable Farming", Zhodino, Belarus \\ * email: nlashina@mail.ru
}

Barley net blotch (causative agent Ascomycete Pyrenophora teres f. teres) is a widespread and harmful disease. Molecular markers of known resistance genes are required for successful breeding on durable resistance. Mapping in a double haploid population (DH) derived from a cross between the resistant cultivar Canadian Lake Shore (CLS) and susceptible Harrington (Dinglasan et al., 2019) and by GWAS (Novokazi et al., 2019) mapped a locus associated with resistance to Pyrenophora teres f. teres on the short arm of chromosome $3 \mathrm{H}$. Based on the identified markers, primers were designed and validated. The evaluations were made in 40 lines of $\mathrm{DH}$ population, and in 46 cultivars and accessions which were resistant to majority studied isolates. Marker JHI-Hv50k-2016-166356 (47.31 cM, $11962783 \mathrm{Mb}$ ) showed 100\% efficiency in co-segregation with resistance in the DH population; markers JHI-Hv50k-2016-165152 (45.82 cM $73225203 \mathrm{Mb}$ ) and Clone ID 3272635 were 95 and 93\% efficient respectively. We observed in 23 of studied 46 resistant cultivars and accessions the expected marker patterns. According to KASP-genotyping data, nine markers localized on chromosome $3 \mathrm{H}$ at interval 47.1 to $54.53 \mathrm{cM}$ contained alternative allelic variants for extreme values of the Pyrenophora teres $\mathrm{f}$. teres resistance trait. Eight of these markers appeared to be intragenic. The developed primers can be used in marker-assisted selection of barley with resistance to net blotch.

Acknowledgements: The research was supported by RFBR grant No. 20-516-00007. 


\title{
Nitrate-activated $C L E$ genes in Medicago truncatula symbiotic nodule development
}

\author{
Lebedeva M.A.*, Yashenkova Ya.S., Dvornikova K.A., Sadikova D.S., Lutova L.A. \\ Saint-Petersburg State University, St. Petersburg, Russia \\ *email: m.a.lebedeva@spbu.ru
}

CLE peptides are important regulators of plant development. In addition to their roles in plant meristems, where CLE peptides regulate the expression of the WOX genes, responsible for stem niche maintenance, CLE peptides were also shown to be systemic regulators capable for long-distance transport in plants. In legume plants, CLE peptides are known as key components of autoregulation of nodulation (AON), which systemically controls the number of nitrogen-fixing nodules formed on the root as a result of symbiotic interaction with soil bacteria rhizobia. CLE peptides are produced in the root in response to rhizobia inoculation and are transported via xylem to the shoot, where they are recognized by CLV1-like receptor kinase, which in its turn inhibit subsequent nodule development in the roots via negative feedback mechanism. Mutations in the gene encoding such CLV1-like kinase in different legumes result in supernodulation - the development of excess number of nodules. In soybean and Lotus japonicus, CLE genes have been described that are activated by nitrate and mediate nitrate-dependent inhibition of nodulation. Our study focuses on nitrate-activated $C L E$ genes in Medicago truncatula. We have identified two genes, MtCLE35 and MtCLE34, activated by both nitrate treatment and rhizobia inoculation in M. truncatula. MtCLE34 overexpression did not reduce the number of noduled on transgenic roots. On the contrary, MtCLE35 overexpression inhibited nodulation on transgenic roots; moreover, such inhibitory effect appeared to be systemic, since nodulation on non-transgenic roots of composite plants bearing MtCLE35-overexpressing roots was also inhibited. We also found that MtCLE35 overexpression did not reduce nodule number in sunn mutant defected in the gene encoding shoot-acting CLV1-like kinase, suggesting that this kinase could be involved in MtCLE35 reception. Therefore, MtCLE35 is a systemic inhibitor of nodulation in response to nitrate, whereas its close homologue MtCLE34 might play a distinct role in nodulation.

Acknowledgements: This work was supported Russian Foundation for Basic Research (RFBR) project 20-016-00129, and grant from Saint-Petersburg State University ID 60256785. 


\section{Gene expression in lichen Lobaria pulmonaria in response to UV-B stress}

Leksin I.Y. ${ }^{1,2 *}$, Minibayeva F.V.1,2

${ }^{1}$ Kazan Institute of Biochemistry and Biophysics, FRC Kazan Scientific Center of the RAS, Kazan, Russia

${ }^{2}$ Kazan Federal University, Kazan, Russia

*email: lecsinilya@mail.ru

Lichens belong to extremophilic organisms, which survive in harsh environments. Mechanisms of their high stress tolerance include regulation at the gene expression level, however there are only few reports on the transcriptome analysis in stressed lichens. In present work we analyzed differential gene expression in the lichen Lobaria pulmonaria in response to UV-B exposure to learn about stress-induced defence proteins and secondary metabolites. Lichen $L$. pulmonaria was chosen due to the availability of information about sequenced genomes of photo- and mycobionts. The thalli of lichen were daily exposed to UV-B radiation for 14 days. Analysis of gene expression of photoand mycobionts was performed by transcriptome analysis and real time PCR. Among differentially expressed genes of photobiont, the most up-regulated were the genes encoding heat shock proteins, antioxidant enzymes, glutathione dependent proteins Mss4-like and glutathione-S-transferase, thioredoxins, alpha-ketoglutarate dependent dioxygenases, genes of nitrogen and lipid metabolism. Among differentially expressed genes of mycobiont, the most up-regulated were the genes involved in protein repair, antioxidative defence, proteolysis and nitrogen metabolism, in particular genes of ornithine cycle, shikimate pathway and amino acid metabolism. Cortex of fungal symbiont of a lichen shields the most of UV radiation, that is why the stress response of mycobiont is stronger than that of photobiont. This caused by the necessity to synthesize photoprotective compounds by mycobiont. We showed that UV exposure of lichen induces the expression of genes involved in the synthesis of dark pigment melanin. Moreover, gene cluster participating in biosynthesis of prenylated xantone, a potential photoprotective metabolite, was also found. Interestingly, genes encoding alternative oxidase were highly expressed in both symbionts in UV exposed thalli suggesting the redistribution of the main respiratory pathways and energy metabolism. Taken together, our data suggest that UV response of L. pulmonaria is regulated by complex interplay between gene activity in photobiont and mycobiont.

Acknowledgements: This work was supported by RSF No. 18-14-00198. 


\title{
Genetic loci for grain protein and gluten content in Russian spring wheat varieties
}

\author{
Leonova I.N. ${ }^{1 *}$, Kiseleva A.A. ${ }^{1,2}$, Stasyuk A.I. ${ }^{1,2}$, Salina E.A. ${ }^{1,2}$ \\ ${ }^{1}$ Institute of Cytology and Genetics, SB RAS, Novosibirsk, Russia \\ ${ }^{2}$ Kurchatov Genomic Center of the Institute of Cytology and Genetics, SB RAS, Novosibirsk, Russia \\ *email: leonova@bionet.nsc.ru
}

The nutritional value of wheat and the quality of flour are largely dependent on the grain protein content (GPC). The development of high-quality wheat varieties, identification of new genetic loci for GPC remains a main task for modern wheat breeding. The aim of this study was analysis of composition of Russian spring bread wheat varieties on genetic loci controlling GPC and gluten content. A panel of wheat varieties was phenotyped at the two localities of Western Siberian region during three years. The GPC of the varieties varied from 12.9 to $17.5 \%$ while gluten content changed from 21.3 to $39.3 \%$ of the total protein content. Heritability of the GPC and gluten was $\sim 0.62$, confirming that environment strongly influence the traits, however the genetic component was also high. Wheat varieties were characterized by markers specific for alleles of loci encoding high molecular weight glutenins (Glu-A1, Glu-B1, and Glu-D1). Summarizing the results of the marker analysis, it was concluded that 27 of 92 varieties contain combinations of Ax2, Dx5 and Dy10 subunits positively effect on baking qualities. Genome-wide association study performed by MLM model revealed SNP markers in 6A, 7B, and 4A chromosomes significantly associated with both protein and gluten content. SNPs, mapped at 6AS chromosome may be linked with NAM-A1 (GPC1) loci - a key factor determining protein and gluten content in common wheat. The obtained results also suggest the presence of new genetic factors that affect the GPC and gluten content in the genome of the bread wheat varieties.

Acknowledgements: This study was supported by the Russian Scientific Foundation (Project No. 21-76-30003) and budget project of the Institute of Cytology and Genetics, SB RAS No. 0259-2021-0012. 


\title{
Investigation of genetic control of agriculturally important traits in common buckwheat using a combination of genetic mapping and transcriptome analysis
}

\author{
Logacheva M.D. ${ }^{1,2 *}$, Kasianov A.S. ${ }^{1}$, Klepikova A.V. ${ }^{1}$, Makarenko M.S. ${ }^{1}$, \\ Schelkunov M.I. ${ }^{1,2}$, Omelchenko D.O. ${ }^{1}$, Fesenko A.N. ${ }^{3}$, Romanova O.I. ${ }^{4}$, Penin A.A. ${ }^{1}$ \\ ${ }^{1}$ Institute for Information Transmission Problems, Moscow, Russia \\ ${ }^{2}$ Skolkovo Institute of Science and Technology, Moscow, Russia \\ ${ }^{3}$ Federal Scientific Center of Legumes and Groat Crops, Orel, Russia \\ ${ }^{4}$ Federal Research Center Vavilov All-Russian Institute of Plant Genetic Resources, St. Petersburg, \\ Russia \\ * email: maria.log@gmail.com
}

Common buckwheat (Fagopyrum esculentum) is an important non-cereal grain crop. Despite this, little is known about the genetic control of agriculturally important traits in this species. Genetic and genomic studies on buckwheat are hampered by low recombination rate and high abundance of retrotransposons. Here we focused on seed shattering habit, inflorescence structure (determinate vs indeterminate) and seed mass as key traits important for the development of highly productive cultivars. We performed crosses of cultivar Dasha with $F$. esculentum ssp. ancestrale - the wild variety that differs from cultivated ones by small and shattering seeds, highly branched inflorescence, indeterminant growth and prolonged seed dormancy. Using genotypingby-sequencing of 567 F2 plants we reconstructed a high-resolution genetic map of common buckwheat containing 1000000 markers polymorphic between F. esculentum ssp. ancestrale and cultivated varieties. For two traits with monogenic inheritance - seed shattering and inflorescence structure - we identified candidate genes based on sequence similarity and expression profiles using a transcriptome atlas: http://travadb.org/browse/Species=Fesc/. One of the key traits is seed shattering; in order to gain deeper insight into its genetic control we analyzed transcriptomes of pedicels in shattering and non-shattering plants. This allowed to delineate the processes involved in seed shattering; in particular, we found extensive changes in the pathways involved in cell wall modification and cell-to-cell interaction (expansins, catenins, plasmodesmata callose-binding proteins). Seed mass is a highly polygenic trait; genotyping revealed several associated loci though this search is not exhaustive due to the limited number of samples.

Acknowledgements: The study is supported by Russian Science Foundation (project No. 18-76-10008). 


\section{CLE and BAM genes in phloem development in potato (Solanum tuberosum L.)}

Losev M.R. ${ }^{1 *}$, Gancheva M.S. ${ }^{1,2}$, Poliushkevich L.O. ${ }^{1}$, Lutova L.A. ${ }^{1}$

${ }^{1}$ Saint-Petersburg State University, St. Petersburg, Russia

${ }^{2}$ All-Russia Research Institute for Agricultural Microbiology, St. Petersburg, Russia

*email: st069730@student.spbu.ru

The phloem is one of the vascular tissues in plants that transports sugars, as well as other important metabolites such as phytohormones and messenger RNAs. It is shown that tuber formation is associated with increased phloem development in the forming tubers, which promotes the influx of substances into the developing tubers. The object of our research is potato, which is an important agricultural crop. The control of phloem development in potato is currently poorly understood, but there is evidence that CLE peptide hormones may be involved in this process. So, in Arabidopsis thaliana, the AtCLE25 peptide is a positive phloem regulator, but AtCLE45 is a negative one. Their receptors are members of the leucine-rich repeat receptor kinase family (CLERK-CLV2 and BAM-CLV1/CLV2 respectively). However, the role of the signal pathway triggered by CLE peptides in phloem development has not been previously studied in potato. In the data on differential gene expression in the potato phloem, we found an accumulation of transcripts of the StCLE19, StCLE12, StBAM1-2, StCLV1, and StBAM3-1 genes. When comparing the sequences of CLE peptides in potato and in Arabidopsis thaliana, it was found that StCLE19 differs from AtCLE25 by only one amino acid, which made the StCLE19 peptide a candidate for the role of a key player in the development of phloem in potato. In turn, the StCLE12 peptide is identical to the AtCLE41 and AtCLE44 peptides, which are involved in the regulation of the activity of another tissue - the cambium. We created constructs for the overexpression of the StCLE12 and StCLE19 genes and found that StCLE12 is indeed involved in the regulation of cambium cell division, and StCLE19 is involved in the development of the phloem. We also created constructs for analyzing the activity of promoters of the StBAM1-2, StCLV1, and StBAM3-1 genes.

Acknowledgements: This work was supported by the RFBR grant 20-316-80004. 


\title{
Development of a genetic map of Vitis vinifera L. backcrossing offspring using high-throughput genotyping
}

\author{
Lytkin K.F. ${ }^{1 *}$, Grigoreva E.A. ${ }^{1,2,3}$, Potokina E.K. ${ }^{1,2}$ \\ ${ }^{1}$ Saint-Petersburg State Forestry University, St. Petersburg, Russia \\ ${ }^{2}$ All-Russian National Research Institute of Viticulture and Winemaking "Magarach" RAS, Yalta, Russia \\ ${ }^{3}$ ITMO University, St. Petersburg, Russia \\ * email: kirill.lytkin@mail.ru
}

Restriction-site associated DNA sequencing (RADseq) technology was employed to identify a large number of single nucleotide polymorphisms (SNP) for BC5 progenies of interspecies crosses between cultivated Vitis vinifera and Vitis rotundifola Michx., which is the most promising source of resistance genes in viticulture, demonstrating almost complete immunity to fungal pathogens. The set of SNP markers was further employed to construct the high-density genetic linkage maps for the $\mathrm{BC}$ crosses as a tool for further mapping of loci, inherited from the donor of resistance.

The high-density genetic linkage maps for BC5 population derived from cross of the maternal genotype 9 M. No. 31-77-10 bred at the "Magarach" Research Institute and source of resistance - paternal lines 2000-305-143 and 2000-305-163. The parental genotypes were expected to carry MrRUN1 gene (resistance to powdery mildew) and MrRPV1 gene (resistance to downy mildew), introgressed from V. rotundifola. On other hand, the parental lines may also inherit some additional loci of resistance from their male parent cv. Regent - a cultivar with quantitative resistance against downy and powdery mildew released in Germany in 1996. For cv. Regent at least two resistance loci for Erysiphe necator (Ren3, Ren 9) and one resistance locus for Plasmopara viticola (Rpv 3.1) were described.

For breeding purposes it is essential to explore genotypes of the populations obtained from crosses involving parental lines 2000-305-143 and 2000-305-163 in order to establish the position of resistance loci on chromosomes. To develop the high-density genetic linkage maps for the hybrid populations two mapping approaches were employed. First, the order of genetic markers in each of linkage group was established based on the reference $V$. vinifera $12 \mathrm{X}$ genome assembly (https://www.ncbi.nlm.nih.gov/assembly/GCF_000003745.3/). Next, the linkage map from the same set of markers was constructed using JoinMap 4 software. For the both approaches the total length of linkage maps was evaluated and compared.

Acknowledgements: The research was supported by the Russian Science Foundation (Project No. 20-16-00060). 


\title{
In vitro biochemical features in calli derived from winter wheat anthers and their possible influences on a secondary embryogenesis
}

\author{
Lyubushkina I. ${ }^{1,2 *}$, Polyakova M. ${ }^{1}$, Pomortsev A. ${ }^{1}$, Kirichenko K. ${ }^{1}$, Sokolova N. ${ }^{1}$, \\ Arbuzova G. ${ }^{1,2}$, Voinikov V. ${ }^{1}$, Anapiyaev B. ${ }^{3}$ \\ ${ }^{1}$ Siberian Institute of Plant Physiology and Biochemistry SB RAS, Irkutsk, Russia \\ ${ }^{2}$ Irkutsk State University, Irkutsk, Russia \\ ${ }^{3}$ Satbayev University, Almaty, Kazakhstan \\ * email: ostrov1873@yandex.ru
}

Nowadays a new findings in double haploid technologies (DHT) let to improve their efficiency and applicability in a world breeding programs. However there are a lot of difficulties in practice of DHT, especial in the area of winter crops using. Thus, in winter wheat, along with embryo-like structures in the culture of isolated anthers, a significant number of rhizogenic calli are formed. They are incapable of secondary embryoidogenesis, and this fact negatively affects the final yield of green regenerant plants. In this work, we investigated the changes of energy metabolism and fatty acid composition in the rhizogenic calli, derived from isolated anthers of winter wheat variety Irkutskaya. This will let us reveal possible influence of rhizogenic calli metabolism features preventing the transition to secondary embryogenesis in the culture. It was shown the respiration rate of rhizogenic calli was about $100 \mathrm{nmol} \mathrm{O}_{2} /(\mathrm{min} * \mathrm{~g}$ fresh weight), while the contribution of alternative pathway to respiration was no more than $10 \%$. At the same time, the high respiration rate was provided mainly due to the increased respiratory activity of the roots formed in these calli. The fatty acid composition of rhizogenic calli was distinguished by an increased content of saturated fatty acids, including pentadecanoic and heptadecanoic acids performed regulatory functions, and a low content of unsaturated fatty acids. Thus, we can conclude that the studied features of the rhizogenic calli metabolism indicate an insufficient supply of cells with the energy necessary to maintain the processes of morphogenesis.

Acknowledgements: The reported study was funded by RFBR, project number 20-34-80003. The research was done using the collections of The Core Facilities Center"Bioresource Center" and the equipment of The Core Facilities Center "Bioanalitika" at Siberian Institute of Plant Physiology and Biochemistry SB RAS (Irkutsk, Russia). 


\title{
Phytochrome A and phytochrome B regulate the biosynthesis of chlorophyll during cytokinin-dependent de-etiolation of Arabidopsis thaliana
}

\author{
Malyukova A.M. ${ }^{1,2 *}$, Doroshenko A.S. ${ }^{1}$, Danilova M.N. ${ }^{1}$ \\ ${ }^{1}$ Timiryazev Institute of Plant Physiology, RAS, Moscow, Russia \\ ${ }^{2}$ Moscow State University, Moscow, Russia \\ * email: anastasia.malukowa@gmail.com
}

Seedling greening during de-etiolation is caused by light-dependent chlorophyll biosynthesis (CB) and development of photosynthetic machinery in chloroplasts. These sweeping changes occur as a result of reprogramming of expression of the nuclear and plastid genomes. In Arabidopsis, most CB genes are encoded in the nucleus. HEMA1 HEMA3 genes encode glutamyl-tRNA reductase, that catalyzes the first step of CB. Another key enzyme in $\mathrm{CB}$ is $\mathrm{Mg}$-chelatase, which is responsible for the insertion of $\mathrm{Mg}^{2+}$ into protoporphyrin IX (CHLD, CHLI, GUN5). GUN4 stimulates CB by stabilizing the $\mathrm{Mg}$-chelatase complex in membranes. White light is the main exogenous positive regulator of $\mathrm{CB}$. Light sensing in plants is performed by photoreceptors, particularly, phytochromes (phyA-phyE) are responsible for the red light perception in A. thaliana. Phytochromes are known to positively regulate $\mathrm{CB}$. In addition to light, cytokinins have a positive effect on $\mathrm{CB}$ : they stimulate the accumulation of mRNA of CB genes, but the mechanism of this positive regulation remains unclear. Analysis of the expression of some key CB genes (HEMA1, GUN5, GUN4) by PCR after reverse transcription showed that both red and white light illumination stimulated the growth in mRNA level in wild type Landsberg erecta (Ler) and knockout mutant phyAphyB seedlings of A. thaliana. Cytokinin treatment of both Ler and phyAphyB resulted in increased level of HEMAI, GUN5, and GUN4 gene transcripts during de-etiolation under white light, but the mutant mostly had a weaker response to the hormone. During cytokinin-dependent de-etiolation under red light, the mRNA levels of some CB genes in Ler were similar to those under white light, but compared with wild type, phyAphyB had a reduced mRNA levels. Thus, phytochromes $\mathrm{A}$ and $\mathrm{B}$ mediate the positive effect of cytokinin on the expression of some CB genes during de-etiolation under both white and red light.

Acknowledgments: This research is supported by the Russian Foundation for Basic Research (grants No. 19-34-90183 and 20-04-00294A). 


\title{
Analysis of stress response genes in moss Dicranum scoparium
}

\author{
Mazina A.B. ${ }^{1,2 *}$, Leksin I.Y. ${ }^{1,2}$, Minibayeva F.V. ${ }^{1,2}$ \\ ${ }^{1}$ Kazan Federal University, Kazan, Russia \\ ${ }^{2}$ Kazan Institute of Biochemistry and Biophysics, FRC KazSC RAS, Kazan, Russia \\ *email:abmazina@gmail.com
}

Mosses are the ancient terrestrial organisms, representing a branch of the evolution of higher plants, where the haploid gametophyte dominates in the life cycle. They can survive in extremely adverse conditions. The mechanisms of plant stress resistance include the expression of genes encoding defence proteins, such as antioxidant enzymes, chaperones, transcription factors. In this work, the following genes were selected: Lea3, F-box, DBF1, PHR1, ATG8. The transcriptomic data (RNA-Seq) of the moss Dicranum scoparium were taken from the NCBI SRA database. The library quality score was checked using FASTQC, then trimming of the reads with Trimmomatic and de novo assembly of the transcriptome using Trinity. From the file with the collected transcripts, a database was created to search for target genes using BLAST+. Protein sequences of target stress genes of the mosses with annotated genomes were used as a request. In D. scoparium, the target stress genes were discovered and found to be present in single homologous sequences. We also analyzed the constituency of each gene for the moss. Expression of stress genes was studied after the moss was subjected to various abiotic stresses, such as heavy metals, temperature stress, prooxidant, photosynthesis inhibitor, dehydration, for 1 and $12 \mathrm{~h}$. The qPCR method revealed that the genes DBF1, F-box, PHRI are genes of a rapid response, while ATG8, Lea3 increased their expression only after prolonged exposure to stresses. Thus, the involvement of these genes in the stress response of Dicranum suggests their evolutionary importance in the survival of higher plants.

Acknowledgements: This work is supported by the RFBR (No. 20-04-00721). 


\title{
Detection of active LTR-retrotransposon via eccDNA analysis in Helianthus annuus L., Arabidopsis thaliana and triticale
}

\author{
Merkulov P. ${ }^{1 *}$, Omarov M. ${ }^{1,2}$, Gvaramiya S. ${ }^{1}$, Kirov I. ${ }^{1}$ \\ ${ }^{1}$ All-Russia Research Institute of Agricultural Biotechnology, Moscow, Russia \\ ${ }^{2}$ National Research University Higher School of Economics, Moscow, Russia \\ * email: paulmerkulov97@gmail.com
}

LTR-retrotransposons present a subclass of mobile genetic elements and can produce extrachromosomal circular DNA (eccDNA) as a byproduct of their life-cycle. Recent studies showed that the amount of LTR-retrotransposon eccDNA molecules is individual for each element and often correlates with the transposition ability. In this way, eccDNA can be used for experimental detection of active retrotransposons in plants as an alternative to whole-genome sequencing. In our study, we aimed to reveal active retrotransposons in Arabidopsis thaliana, Helianthus annuus L. and triticale ( $\times$ Triticosecale Wittmack). Later two species have relatively large and repeat-rich genomes. Total genomic DNA was isolated and treated with plasmid-safe exonuclease for eccDNA enrichment. Then we performed a Rolling Circle Amplification (RCA) reaction followed by inverse PCR with specific primers. In $H$. annuus we detected eccDNA for LTR-retrotransposon (named Gagarin) located on chromosome 1. For triticale, we detected a retrotransposon (named $M I G$ ) located on chromosome 7B and produced eccDNA molecules. Using RT-PCR analysis and direct RNA Nanopore sequencing we also detected different isoforms for these retrotransposons. In conclusion, eccDNA detection is an accurate method for the identification of active LTRretrotransposons in large and repetitive plant genomes.

Acknowledgements: The reported study was funded by RFBR, project number 20-3470032. 
DOI 10.18699/PlantGen2021-132

\title{
The allelic diversity study of regulatory genes involved in flavonoid biosynthesis in cotton
}

\author{
Mikhailova A.S. ${ }^{1,2 *}$, Strygina K.V. ${ }^{2}$, Khlestkina E.K. ${ }^{2}$ \\ ${ }^{1}$ Saint-Petersburg State University, St. Petersburg, Russia \\ ${ }^{2}$ Federal Research Center N. I. Vavilov All-Russian Institute of Plant Genetic Resources, St. Petersburg, \\ Russia \\ *email: a.mikhailova@vir.nw.ru
}

Cotton is known to be a widely used raw material of strategic purpose. Naturally colored cotton fibres are hypoallergenic and do not lead to environmental pollution due to the textile industry residuals. Proanthocyanidins (PAs) in cotton fibres provide various brown shades colouring. The control of PAs biosynthesis is under R2R3-Myb, bHLH$\mathrm{Myc}$, and WD40 transcription factors (TF) forming MBW regulatory complex. The aim of this research includes revealing allelic diversity of PAs biosynthesis regulatory genes among G. hirsutum L. cotton samples of VIR collection. For the first time identification and characterization of homoeologous and paralogous R2R3-Myb, bHLH-Myc, and WDR genes copies in genomes of diploid and allotetraploid cotton species $(G$. arboretum $\mathrm{A} 2, G$. raimondii D5, $G$. hirsutum AD1, and $G$. barbadense AD2) were provided. In silico analysis of copies belong to the gene families $R 2 R 3-M y b$ (TT2-1, TT22, TT2-3, MYB10 genes; 24 in total), bHLH-Myc (TT8-1, TT8-2 genes; 12 in total), and WDR (TTG1, TTG3 genes; 11 in total) gives comprehensive information concerning structural gene organization and evolutionary aspects of gene formation. In addition to this, the GhTTG1/GhTTG3 (WDR) genes were demonstrated to be the most conservative and predominantly supported by the selection, while the GhTT2/GhMYB10 and GhTT8 genes are more variable therefore are preferable for molecular marker development. Resequencing uncovers deletion in the promoter region of the third GhTT2-A3 gene copy (chromosome 7A) and insertion about $18 \mathrm{bp}$ in GhMYB10-A sequence (chromosome 10A) in A-genome of light-brown coloured cotton. Moreover, the specific primer pair allows predicting white, light-brown, and dark-brown cotton fibre phenotype through different PCR-products lengths. Obtained findings can be adapted for the design of potential diagnostic markers for the selection of cotton varieties with naturally coloured fibres.

Acknowledgements: This work was conducted within the framework of the state task regarding to Theme No. 0481-2019-0001. 


\title{
Molecular phylogeny of plant 14-3-3 proteins family
}

\author{
Mikhaylova Yu.V. ${ }^{1 *}$, Shishova M.F. ${ }^{2}$ \\ ${ }^{1}$ Komarov Botanical Institute Institute RAS, St. Petersburg, Russia \\ ${ }^{2}$ St. Petersburg State University, St. Petersburg, Russia \\ * email: YMikhaylova@binran.ru
}

14-3-3 proteins are conservative and wildly spread family of phosphate group-binding modulators required for protein-protein interaction. In plants 14-3-3 family members involved in regulation of such processes as cell division, growth and differentiation, as well as responses to different stress factors, implementation of hormone signalling and modification of metabolism. In the present work, we performed evolutionary analysis of 14-3-3 proteins in broad phylogenetic scale. We analysed 14-3-3 proteins in flowering plants including not only well studied model plants, but also important for understanding of angiosperm evolution species, like ancient basal angiosperm Amborella. We use for the analysis coding sequences of 14-3-3 genes, obtained from Phytozome 12 and GenBank NCBI databases. Sequences were aligned using MAFFT. Maximum likelihood (ML) phylogenetic analysis was performed using IQ-TREE algorithm. Sequence of yeast 14-3-3 protein BMH1 (UniProt A6ZRD4) was used as outgroup. 42 plant species from monocots, dicots and Amborella were sampled. Total number of 455 sequences broke into two major clades, which are 163 in epsilon-group and 292 in non-epsilon group of 14-3-3. The presence of both epsilon and non-epsilon isoforms in Amborella means that the split is ancient. Revealed diversification could take place in the early period of seed plants evolution. The observed distribution of isoforms in angiosperms species suggests that ancestral forms of epsilon, iota, psi and kappa 14-3-3 isoforms diverged in common ancestral of all flowering plants. Later in common ancestral of monocots and eudicots $\mathrm{mu}$ and omega groups segregated from epsilon and psi respectively. Subsequent whole genome duplication event formed variety of isoforms in different evolution lines of flowering plants. Therefore, in Amborella, that only species have no whole-genome duplication in its evolutionary history, there are only four isoforms of 14-3-3 protein. The opposite example is Brassicaceae, which experienced many rounds of whole genome duplications. As a result Arabidopsis has 13 isoforms of 14-3-3 proteins.

Acknowledgements: The work was supported by RFBI (No. 19-04-00655). 


\title{
Epigenetic mechanism of wheat adaptation on a response to the abiotic stress
}

\author{
Minasbekyan L.A.*, Vardevanyan P.O. \\ Yerevan State University, SRI "Biology”, Department of Biophysics, Yerevan, Armenia \\ *email:minlia@ysu.am
}

Electromagnetic radiation of the radiofrequency waveband is the new anthropogenic factor of the environment and research into its influence on living organisms is of great interest. Today in Armenia there are 3 mobile network operators: Beeline, Viva Cell MTS, and U-com. The problem of electromagnetic safety becomes extremely relevant since the most technical, telecommunication, and medical devices radiate mm-wave in the range of 3-300 GHz. Thus, the territory of relatively small Armenia is covered three times by large telecommunication operators, which undoubtedly harms human health. Rearrangements in the nuclear envelope and the content of soluble nuclear fraction are reflected in the genome state. Although the genome is often depicted as a static structure upon which protein factors bind to control the turn of expression, the genome is actually highly mobile and capable of exploring the complex domain architecture of the nucleus, which in turn controls genome maintenance and gene expression. The impact of EHF EMI (Extremely High Frequencies Electromagnetic Irradiation) of the mm-range (45-53 $\mathrm{GHz}$ ) on protein, RNA, and DNA content in the composition of the nuclear envelope and a soluble nuclear fraction of wheat seedlings on the 4- day after irradiation have been studied. These modifications in nuclei content of seeds during growth after exposure by EMF may be related to abnormal photosynthetic activity, as well as with plant transcriptome activity, which more visible by study modulation in the content of 5-mC DNA methylation. The part of investigated seedlings was growing in soil to get a harvest of second-generation. Obtained in our study data shows that the changes in the level of DNA methylation in the first generation of seeds during the plant ontogeny are conserved and partially pass to the seedlings of second-generation seeds. So we have shown that changes in the content of nuclei and DNA methylation levels can be passed to the next generation and provide a memory that enables the plant and even its offspring to adapt better to subsequent stress through epigenetic mechanisms. 


\title{
CRISPR/Cas9 - mediated genome editing of bread wheat to modulate heading time
}

\author{
Miroshnichenko D. ${ }^{1,2,3 *}$, Timerbaev V.1,2,3, Klementyeva A. ${ }^{2,3}$, Salina E. ${ }^{4}$, \\ Dolgov S. ${ }^{2,3}$ \\ ${ }^{1}$ Kurchatov Genomic Center - ARRIAB, All-Russia Research Institute of Agricultural Biotechnology, \\ Moscow, Russia \\ ${ }^{2}$ Shemyakin and Ovchinnikov Institute of Bioorganic Chemistry RAS, Pushchino, Russia \\ ${ }^{3}$ All-Russia Research Institute of Agricultural Biotechnology, Moscow, Russia \\ ${ }^{4}$ Institute of Cytology and Genetics, SB RAS, Novosibirsk, Russia \\ *email: miroshnichenko@bibch.ru
}

The heading time of spring and winter varieties largely depends on their need for vernalization and controlled by a group of coordinated $V R N$ genes (VRN1, VRN2, VRN3 and VRN4). In bread wheat the presence of at least one dominant allele of VRN1 gene homologue (Vrn-Al, Vrn-Bl, or Vrn-Dl) determines the spring growth habit; winter wheat contains only recessive alleles. Various combinations of dominant/recessive homologues can lead to differences in flowering time, height of plants and yield. The functional difference between dominant and recessive alleles associated with a presence of mutations in the promoter region or the first intron of $\mathrm{Vrn}-1$. The goal of our study was to produce wheat plants with new nucleotide changes in the conserved promoter region of the recessive $v r n-A l$ gene using genomic editing technique. We have developed an effective protocol for delivery of editing components of the CRISPR/Cas9 system into wheat calli, followed by the regeneration of genome edited plants. As a result of co-transformation by two vectors, carrying the sequence of $v r n-A l$-specific guide sgRNA and the Cas9 nuclease, a number of independent events containing various changes in the promoter region were produced. Analysis of the T1-T2 seed generation confirmed the inheritance of mutant promoter variants including single nucleotide deletion/ substitutions, and deletion of four-eight nucleotides. More detailed results concerning the efficiency of bread wheat genome editing using various types of sgRNA, the possibility to clean up the plants from 'editing tools' sequence, and the impact of genomic edits on an earing time will be presented.

Funding: Kurchatov Genomic Center of All-Russia Research Institute of Agricultural Biotechnology, agreement No. 075-15-2019-1667. 


\title{
Genome-wide approaches in the study of common fig in the Nikita Botanical Gardens
}

\author{
Mitrofanova I.*, Krivenko O., Kuleshova O., Emirsaliev A., Tsyupka V. \\ Federal State Funded Institution of Science "The Nikita Botanical Gardens - National Scientific Center \\ of the RAS" (NBG-NSC), Yalta, Russia \\ * email: invitro_plant@mail.ru
}

Fig is one of the most ancient subtropical fruit crops using in food, cosmetic, and soap industries as well as in medicine, which industrial production is hindered by the lack of intensive cultivation technologies. Genome-wide approaches provide an effective tool for the development and implementation of the modern molecular breeding strategies in the fig cultivation. The Nikita Botanical Gardens (NBG-NSC) has a unique common fig collection represented by 267 cultivars and hybrid forms including of local breeding. A comprehensive genomic study of the common fig collection started in the NBG-NSC a few years ago and four main researcher projects are ongoing. First version of the reference genome of the local cultivar Ficus carica 'Sabrutsiya Rozovaya' was obtained by hybrid assembly using combined long and short read genome wide sequencing datasets. To identify the molecular determinants of fig resistance to complex abiotic stress, we investigate changes in a differential gene expression during adaptation of in vitro cultivate plants to in vivo and ex situ conditions based on the transcriptomes analysis of the leaves obtained from three $F$. carica cultivars with alternative phenotypes. Methodological framework for the investigation of the molecular mechanisms of cell differentiation in plants based on the single-cell RNA-sequencing analysis are developing using in vitro $F$. carica culture. A detail description of the genetic diversity of the fig collection, including sequencing of the key cultivars, genotyping of the collection, with a focus on the traits responsible for resistance to abiotic and biotic stress, will make a base for the development of advanced genomic breeding and cultivation fig technologies in the NBG-NSC.

Acknowledgements: The first two projects are supported by the grant No. 075-15-20191670 of the Ministry of Science and Higher Education of Russian Federation and done in Kurchatov Genomic Center - NBG-NSC; the other are conducted in the frame of the State Task No. 0829-2019-0038 of FSFIS “NBG-NSC”. 


\title{
Analysis and editing the maize gamete interactions and fusion genes
}

\author{
Moiseeva E.M., Gusev Yu.S., Fadeev V.V., Mazilov S.I., Chumakov M.I.* \\ Institute of Biochemistry and Physiology of Plants and Microorganisms, Russian Academy of Sciences, \\ Saratov, Russia \\ *email: chumakov_m@ibppm.ru
}

The molecular-genetic aspects of double fertilization in angiosperms plants, discovered by S. Navashin over a hundred years ago (1896), still remains poorly understood. In the case of gynogenesis one of the spermium does not merge with the egg cell and haploid plant develop the parthenogenetic embryo from unfertilized egg cell. The knowledge of the mechanism of gamete membrane interaction and fusion may be of practical use for haploid-inducing maize line production. We analyzed the gynogenesis (parthenogenesis) genes in maize, in they involvement in the gamete membrane interaction and fusion. Particular, the maize $Z m \_g e x 2$ and $Z m \_g c s 1$ genes, which we for the first time described in 2017 may be involved in gynogenesis also. For creation the CRISPR/Cas 9 constructs on the base pRGEB-32BAR vector, designed for maize plants, were synthesized three gRNA for Zm_gex2 and two gRNA for Zm_gcs 1 maize genes, and introduced into the maize genome for knockout of these genes by the in planta method. We harvested about four thousand seeds after agrobacterial transformation BM maize line with CRISPR/Cas9-constructs with sgRNA to Zm_gex2 and Zm_gcs1 genes by the in planta method. PCR was applied for analysis of two thousand 2-week old seedlings, and $15 \mathrm{~T}$ DNA insertions was found, but only for 7 maize plants transformation was confirmed by the sequences method.

Acknowledgements: This work was carried out within the Russian Program of Basic Research of the state academies of sciences for 2021-2023 (registration No. 121031700141-7) and supported by the Russian Foundation for Basic Research, grants №20-016-00020a (Zm_gex2) and No. 20-316-80020/20 (Zm_gcsl). 


\title{
Evolutionary complexification of plant information structure under influence of permanent data flow
}

\author{
Moldavanov A. \\ Belkin International Inc., Los Angeles, USA \\ email: trandrei8@gmail.com
}

\begin{abstract}
Numerical and analytical simulation targeting a process of complexification for information structure of plant's subsystem is conducted. Plant's subsystem is considered as an open thermodynamic system and simulation employs the mathematical model utilizing formalism of randomized continuity equation. Approximation of open system is achieved by use of infinite number of links with environment in assumption that all links are executed by continuity equation for information exchange. Following this approach we deal with a phase space at determined exchange rate and random interface factor. Found solution is a function of an information interface factor and in its physical meaning is an integral efficiency of information exchange. Executed formalism assumes natural extension to computation methods based on binomial probability distribution. Discovered solution possesses the built-in mechanism for phasing (existence of the stages of dissimilar physical meaning), dynamic transformation of topology for information exchange, predetermined change of range for random variations, and existence of specific fluctuations for information components of complexification process. Verification of results is conducted by numerical methods.
\end{abstract}




\title{
The effect of salt stress on the expression of the brassinosteroid biosynthesis genes
}

\author{
Murgan O.K.*, Efimova M.V. \\ National Research Tomsk State University, Tomsk, Russia \\ * email: reborn_rinni@mail.ru
}

Soil salinization is one of the most unfavorable environmental factors caused by the increased anthropogenic load on the environment. This process is most actively developing on irrigated agricultural soils in arid zones. Excessive sodium chloride content in the soil negatively affects the implementation of many physiological processes in plants, largely due to the generation of reactive oxygen species and the development of oxidative stress. This leads to disruption of the photosynthetic apparatus, a decrease in the intensity of photosynthesis and, as a consequence, a decrease in the productivity of plants; induction of aging or premature death of the plant. Therefore, it is necessary to increase the salt tolerance of agricultural crops. Components of a phytohormonal nature, such as brassinosteroids, are considered as a regulator of plant resistance. Their protective properties under abiotic stress are currently being actively studied. However, the mechanisms underlying the protective effect have not yet been established. We showed the changes in the intensity of the brassinosteroid synthesis genes (CYP450 A90, DET2) expression of Solanum tuberosum (cultivar Lugovskoy) under salinity stress.

Funding: The reported study was funded by RFBR, project number 20-34-90094. 


\title{
Functional analysis of Solanum lycopersicum $\mathbf{L}$. MADS-box gene SIMADS5
}

\author{
Nezhdanova A.V.*, Slugina M.A., Dyachenko E.A., Kamionskaya A.M., \\ Kochieva E.Z., Shchennikova A.V. \\ Institute of Bioengineering, Federal Research Centre "Fundamentals of Biotechnology" of the Russian \\ Academy of Sciences, Moscow, Russia \\ *email: anna-negdanova@mail.ru
}

Highly conserved MADS-domain transcription factors play a decisive role during angiosperm flowering. Their combinatorial action is described by the ABCDE flower development model. E-class SEPALLATA (SEP) proteins determine flower organ identity and are the central hub of MADS-protein complexes. Tomato (Solanum lycopersicum) SEP3 homolog, SIMADS5, is involved in determining petal, stamen, and carpel identity; data on this gene function are limited. In this study, SIMADS5 functional characteristic was performed. Phylogenetic analysis confirmed SIMADS5 belonging to the SEP3-clade, and expression analysis revealed the absence of gene transcripts in roots, leaves, and shoot apical meristems, and their presence in flowers, fruits, and seeds. Twohybrid analysis showed SIMADS5 ability to activate target gene transcription and interact with TAGL1. Compared to non-transgenic control, transgenic Nicotiana tabacum L. plants with SIMADS5 overexpression bloomed 2.2 times later and formed thicker leaves, 2.5-3.0 times thicker stem, 1.5-2.7 times shortened internodes, and 1.9 times fewer flowers and capsules; the corolla color has changed from a pink to magenta. Expression analysis of SIMADS5 and tobacco MADS-box genes NtLFY, NtAP1, NtWUS, $N t A G, N t P L E, N t S E P 1, N t S E P 2$, and NtSEP3 in the leaves and apexes of transgenic and control plants showed the presence of SIMADS5 in transgenic lines. The other genes were highly expressed only in the reproductive meristems of control plants. The results obtained confirm the SIMADS5 participation in determining the petal, stamen, and carpel identity in tomato flower, and show that ectopic expression of this single gene can lead to a long-term arrest of the plant reproductive development.

Acknowledgements: This study was supported by the Russian Foundation for Basic Research (grant 18-29-07007) and the Ministry of Science and Higher Education of the Russian Federation, and was performed using the experimental climate control facility (Institute of Bioengineering, Research Centre of Biotechnology, Russian Academy of Sciences). 


\title{
Genome assemblies of Fusarium oxysporum f. sp. lini strains of different virulence
}

\author{
Novakovskiy R.O. ${ }^{1 *}$, Dvorianinova E.M. ${ }^{1,2}$, Rozhmina T.A. ${ }^{3}$, Kudryavtseva L.P. ${ }^{3}$, \\ Povkhova L.V. ${ }^{1,2}$, Pushkova E.N. ${ }^{1}$, Melnikova N.V. ${ }^{1}$, Dmitriev A.A. ${ }^{1}$ \\ ${ }^{1}$ Engelhardt Institute of Molecular Biology, Russian Academy of Sciences, Moscow, Russia \\ ${ }^{2}$ Moscow Institute of Physics and Technology, Dolgoprudny, Russia \\ ${ }^{3}$ Federal Research Center for Bast Fiber Crops, Torzhok, Russia \\ * email: Olegovich46@mail.ru
}

Since the last century Fusarium oxysporum f. sp. lini has been known as one of the most devastating flax pathogens. At the same time, the severity of the disease symptoms it causes varies, whereas the forma specialis includes numerous strains of different pathogenicity degrees. However, the molecular basis of such diversity has not been investigated yet. To fill the knowledge gap, we performed whole-genome sequencing of 5 strains of $F$. oxysporum f. sp. lini of different pathogenicity degrees: high (\#483), medium (\#476, \#525), and low (\#456, \#482) ones. We obtained the DNA of these fungi according to our previously developed protocol and sequenced the libraries on Oxford Nanopore Technologies (MinION, R9.4.1, 10× coverage on average) and Illumina (MiSeq, $300+300 \mathrm{bp}$, 50x coverage on average) platforms. Using both types of the obtained raw data as well as the Nanopore and Illumina reads of a highly pathogenic isolate \#39, which were received earlier, we assembled the genomes of the 6 strains with a hybrid assembler MaSuRCA. The lengths of the assemblies were in the range of 53$69 \mathrm{Mb}, \mathrm{N} 50$ values $-1.0-2.5 \mathrm{Mb}$, and the BUSCO completeness - 96.5-99.7\%. Then, the sequences of the SIX genes of F. oxysporum f. sp. lini (SIX1, SIX7, SIX11, SIX12, SIX13) were downloaded from GenBank, as this class is associated with virulence in F. oxysporum species. The search with BLAST (the blastn algorithm) revealed that all our assemblies contain the query sequences except for the genome of the low virulent strain \#482. The received data helps understand the virulence mechanisms of the flax pathogen and elaborate methods to combat it.

Acknowledgements: This work was funded by RFBR according to the research project 19-34-90055. 


\title{
Molecular genetic methods for assessing drought resistance of spring barley
}

\author{
Novikova A.A., Bogdanova O.V.* \\ Federal Research Centre of Biological Systems and Agrotechnologies of Russian Academy of Sciences, \\ Orenburg, Russia \\ *email: olga_bogdanova_1995@mail.ru
}

The creation of varieties with high adaptive potential is an important condition for the formation of highly productive agroecotypes. In the conditions of sharply continental climate of the Southern Urals, the lack of moisture during the growing season is a limiting factor in realization of the potential yield of agricultural crops. In the breeding process, the assessment of the drought resistance of the variety is based on long-term observations in the field. The introduction of molecular genetic methods for assessing plant material will eliminate dependence on weather conditions, shorten the research time and increase the efficiency of selection.

As an object of research, we took varieties and lines of spring barley from the control nursery of the Department of Breeding and Seed Production of Grain Crops of the Federal State Budgetary Research Institution FSC BST RAS. For research, a working sample was formed, it included 150 samples with high potential productivity. The spring barley variety Natali was used as a control. The prevailing conditions of weather factors served as a good background for assessing the material for its resistance to air and soil droughts (the amount of precipitation was more than 2 times lower than the average long-term values). Phenotypic assessment and assessment of productivity indicators of the stem showed that the numbers have a wide norm of reaction to stress caused by a lack of moisture.

The second stage of the research includes the formulation of a methodology and assessment of drought tolerance of cultivars by the method of quantitative assessment of cDNA genes associated with the response of plants to water stress. Total RNA is planned to be isolated from etiolated seedlings using ready-made kits according to the manufacturer's instructions.

In conclusion, the assessment of the genetic potential of the working sample, the degree of phenotypic manifestation of the studied genes will be carried out, and donors of economically valuable traits will be selected. 


\title{
Manganese-containing bionanocomposites on the basis of natural polysaccharides as novel universal micronutrients for Solanum tuberosum $\mathbf{L}$.
}

\author{
Nozhkina O.A. ${ }^{1}$, Perfileva A.I. ${ }^{1 *}$, Khutsishvili S.S. ${ }^{2}$, Ganenko T.V. ${ }^{2}$ \\ ${ }^{1}$ A.E. Favorsky Irkutsk Institute of Chemistry SB RAS, Irkutsk, 664033, Russia \\ ${ }^{2}$ Siberian Institute of Plant Physiology and Biochemistry SB RAS, Irkutsk, 664033, Russia \\ * email: alla.light@mail.ru
}

The study of the qualitative and quantitative effect of manganese on the vegetation of plants was carried out on the model system of potatoes in vitro, new information was obtained on the mechanism of migration of metal ions, the general toxicological effect of metal on development and the identification of optimal conditions for their entry into the plant organism using the example of Solanum tuberosum L. Novel manganesecontaining bionanocomposites based on polysaccharides (arabinogalactan, sulfated arabinogalactan, $\kappa$-carrageenan) have been synthesized as potential universal trophic low-dose micronutrients, and the structural features of nanocomposites, the ability of original matrices to form stable composite materials and their supramolecular organization have been investigated. The data obtained are relevant in the light of studying the mechanisms of potato survival on saline soils and in private farms in the immediate vicinity of industrial enterprises, and also allow one to assess the plant's capabilities for metal accumulation. The study of the development of plants in nutrient media with different salt content made it possible to compare with plants developing in a nutrient medium with bionanocomposites as a carrier of mineral fertilizers. It is important to note that potato plants grown on a medium with nanocomposites performed better in biometrics. Also, among the most important results it is worth noting that the resulting nanocomposites have an antibacterial effect against the phytopathogenic bacteria Clavibacter sepedonicus and the formation of bacterial biofilms. Growing plants in an environment with manganese-containing nanocomposites promoted an increase in the activity of the protective enzyme peroxidase in leaf tissues as compared to the control. In addition, according to the results obtained, the studied manganesecontaining nanocomposites are safe for representatives of soil microflora.

Acknowledgments: The reported study was funded by RFBR 20-016-00152 A. The authors are grateful to the Baikal Analytical Center of Collective Use, SB RAS. 


\title{
Analysis of the distribution of parameter of membrane lipid phase state
}

\author{
Nurminsky V.N. ${ }^{1 *}$, Bukin Yu.S. ${ }^{2}$, Ozolina N.V. ${ }^{1}$ \\ ${ }^{1}$ Siberian Institute of Plant Physiology and Biochemistry, SB RAS, Irkutsk, Russia \\ ${ }^{2}$ Limnological Institute, SB RAS, Irkutsk, Russia \\ *email: cell@sifibr.irk.ru
}

On the basis of the $\mathrm{R}$ programming language, a technique has been developed for analyzing data on the packing density (phase state, lipid order) of the membrane lipid phase obtained by measuring the generalized polarization (GP) of the fluorescence of probe laurdan. It is known that the fluorescence spectrum of laurdan changes depending on the ordering (microviscosity) of the lipid phase. The histograms of distributions of GP values reflect the degree of ordering of the lipid phase, and make it possible to reveal the presence of membrane heterogeneity (membrane rafts). The developed analysis allows constructing a theoretical multimodal distribution as a superposition (overlay) of several normal distributions using the method of least squares. The limitation on the number of components (modes) for describing the distribution of the GP value is conducted using two indicators of informative significance - the Akaike information criterion (AIC) and the Bayesian information criterion (BIC). The multimodal distribution with such a number of normally distributed modes (components), for which the value of the covariance coefficient $\mathrm{R}^{2}>0.99$, with the minimum values of AIC and BIC, was chosen as the optimal one. To test the technique, we analyzed the ordering of lipids in the raft membranes of mitochondrial membranes in halophytes Salicornia perennans Willd., Halocnemum strobilaceum Bieb. and Artemisia santonica L., differing in the salt tolerance. According to the analysis of lipid ordering, the membrane material of the mitochondria of $S$. perennans, H. strobilaceum, and A. santonica may contain raft structures. So, the analysis of data on the density (ordering) of the lipid phase of the membrane by measuring the GP fluorescence of the laurdan probe can be used to identify more densely packed raft structures in the membrane.

Acknowledgments: This work was carried out with partial use of the Russian Foundation for Basic Research, grant No. 19-04-00013. 


\title{
Molecular screening of susceptibility genes $T s n 1$ and Snn1 in the accessions of genus Triticum $\mathbf{L}$. for resistance to the toxins SnToxA and SnTox1 from the Stagonospora nodorum
}

\author{
Nuzhnaya T.V.*, Veselova S.V., Burkhanova G.F., Shein M.Yu., Maksimov I.V. \\ Institute of Biochemistry and Genetics of the UFRC of the RAS, Ufa, Russia \\ *email: tanyawww89@mail.ru
}

The virulence factors of the pathogen Stagonospora nodorum Berk. are numerous necrotrophic effectors (NE) (SnTox) that interact with the products of host susceptibility genes $(\mathrm{Snn})$ causing the development of the disease. In the present work, we have studied SnToxA-Tsn1 and SnTox1-Snn1 interactions resulting in development of necrosis and chlorosis in wheat plant tissues with the formation of extensive lesions. We selected two $S$. nodorum isolates ( $\mathrm{SnB}$ and $\mathrm{Sn} 9 \mathrm{MN}$ ) for screening wheat accessions of the genus Triticum L., which differ in the expression of NE. We evaluated about 70 wheat accessions of the genus Triticum L. for the presence of alleles of the Tsn1 and SnnI genes. We studied 12 varieties of soft spring wheat and 34 varieties of winter wheat, 12 accessions of polyploid wheat species from the Vavilov wheat collection. Cultivars with two dominant alleles of both genes were found, and the dominant allele of the Tsn 1 gene was more common in cultivars with a winter type of development. There were the most varieties with one dominant allele of the Snnl gene; such accessions were found among the spring and winter types of development. Accessions with two recessive alleles turned out to be mainly mono-, di-, and tetraploid wheat. In all wheat accessions, the degree of resistance to the pathogen was determined by the area of leaf damage. We found two resistant accessions among polyploid wheat species, two resistant genotypes among spring varieties and 11 resistant and 6 medium resistant genotypes among winter wheat. It was shown that variety resistance can be determined by the level of expression of the susceptibility genes $T s n 1$ and Snnl.

Acknowledgements: This work was supported by the RFBR in the framework of the research project No. 20-316-80047. 


\section{Epigenetic profiling of plant LTR retrotransposon copies using Nanopore sequencing}

Omarov M. ${ }^{1,2 *}$, Merkulov P. ${ }^{1}$, Gvaramiya S. ${ }^{1}$, Kirov I. ${ }^{1}$

${ }^{1}$ All-Russia Research Institute of Agricultural Biotechnology, Moscow, Russia

${ }^{2}$ National Research University Higher School of Economics, Moscow, Russia

*email: muradok98@gmail.com

Transposable elements (TEs) are of great interest as a source of plant genome diversity. DNA methylation is a major barrier that inhibits TE activity playing an important role in the control of genome integrity. However, the methylation profile of individual recently originated TE copies can not be established using short-read bisulfite sequencing, the gold standard of cytosine methylation detection. In addition, incomplete conversion and DNA degradation during bisulfite treatment also limit the application of this method. Nanopore sequencing provides great opportunities for DNA methylation profiling. DNA methylation can be directly detected from native DNA reads by tracking changes in electrical potential without extra laboratory technique. Moreover, the long reads of Nanopore sequencing makes it possible to profile DNA methylation of repetitive and low complexity regions. To investigate the epigenetic features of distinct copies of potentially active LTR retrotransposons in Arabidopsis thaliana, we at the first time for plants carried out Cas9-targeted Nanopore sequencing followed by detection of DNA methylation in three different contexts $(\mathrm{CG}, \mathrm{CHG}$ and $\mathrm{CHH})$. Our epigenetic profiling showed an interesting correlation of methylation distribution of individual TE copies and their transcription sites. We compared the epigenetic profiles of individual retrotransposon copies in Arabidopsis thaliana wild type and a mutant defective in one of the methylation pathways. We found up to $50 \%$ decrease of methylation level in mutant plants corroborating with bisulfite sequencing results. In conclusion, we showed that Nanopore-based DNA methylation detection in combination with Cas9-targeted sequencing are useful approaches for illuminating the epigenetic regulation of TEs. 


\section{Auxin-ethylene transcriptional crosstalk in Arabidopsis thaliana $\mathbf{L}$.}

Omelyanchuk N.A. ${ }^{1 *}$, Ubogoeva E.V. ${ }^{1}$, Zemlyanskaya E.V. ${ }^{1,2}$

${ }^{1}$ Institute of Cytology and Genetics, SB RAS, Novosibirsk, Russia

${ }^{2}$ Novosibirsk State University, Novosibirsk, Russia

*email:nadya@bionet.nsc.ru

Phytohormones auxin and ethylene are key regulators of plant development and responses to environmental changes targeting these processes independently or together. Many aspects of interplay between auxin and ethylene were described but systematic overview assessing intensity of their interaction (existence of common targets, involvement in regulation of partner metabolism or signaling) is still lacking. Herein, we investigated auxin-ethylene transcriptional crosstalk at whole-genome resolution carrying out meta-analysis of transcriptome changes in Arabidopsis thaliana triggered by external application of auxin or ethylene.

Clustering of auxin and ethylene responsive transcriptomes segregated them according to treatment duration and organ specificity. Gene ontology (GO) annotation of differentially expressed genes (DEGs) in the clusters unveiled involvement of some of them in processes regulated by both hormones similarly or antagonistically. For example, both ethylene and auxin upregulate chitin and cadmium responses. Otherwise, auxin upregulates whereas ethylene downregulates unidimensional cell growth. Besides, both hormones regulate response to each other and cooperate in the control of responses to other hormones, cold and salt stresses, and development (cell wall organization and root hair elongation).

Genes differentially expressed in response to both hormones (common targets) were classified according to direction of expression changes (up- or downregulation). GO annotation of these groups identified processes enriched with common targets regulated in concert by auxin and ethylene. Intersecting the results on functional annotation of DEGs and common targets resulted in subdivision of processes regulated by both hormones into enriched and not enriched with common targets.

We extracted from the list of auxin induced DEGs genes involved in ethylene metabolism and signaling and vice versa. We left in both lists only genes, which involvement has references to the published papers. Then we embed these "hidden" interactions into the processes regulated by auxin and ethylene. Thus, we provide a roadmap of auxin-ethylene crosstalk at the transcriptional level integrating all main aspects of their interactions.

Acknowledgments: This work was supported by the RSF grant 20-14-00140. 


\section{Class III peroxidase genes in the moss Dicranum scoparium: identification and expression analysis under abiotic stresses}

Onele A.O.*, Mazina A.B., Leksin I.Y., Chasov A.V., Minibayeva F.V.

Kazan Institute of Biochemistry and Biophysics FRC KazSC RAS, Kazan, Russia

* email: donjay.ao@gmail.com

Class III peroxidase (POD) enzymes participate in plant development, hormone signaling, and stress responses. In vascular plants, POD genes have been extensively studied using genome-wide identification and expression analysis. Mosses are the second most diverse terrestrial plants, with approximately 13,000 species and can survive in a variety of harsh environmental conditions. Despite their high tolerance to biotic and abiotic stresses, there are only few reports on the expression of $P O D$ genes in the mosses. In this study, we identified class III POD genes of $D$. scoparium from the NCBI database, performed molecular characterization and studied the expression of these genes under abiotic stresses. Bioinformatic analysis of retrieved sequences revealed that they all have classical POD domain structures and were designated as DsPOD1 to DsPOD22. To further characterize DsPOD proteins, 8 DsPODs highly homologous to class III PODs of Pohlia nutans and Physcomitrella patens were selected. Several post-translational modification sites and functional elements such as haem ligand and active sites necessary for enzymatic activity were found. In addition, secondary and tertiary structure prediction showed that DsPODs mainly consist of $\alpha$ helixes and random coils. Despite the presence of the majority of DsPODs in the extracellular space, the result of phylogenetic analysis demonstrated that DsPODs are clustered in different branches, probably due to the diverse nature of POD isoforms or duplication in the genome of $D$. scoparium. Among the 8 selected $D s P O D$ genes, only DsPOD1, DsPOD2, DsPOD6 and DsPOD 8 were found to be highly induced in response to desiccation/rehydration, $\mathrm{CdCl}_{2}$, paraquat and temperature treatments and exhibited variable expression patterns, suggesting functional diversification of these genes. The upregulation of $D S P O D s$ in response to different stress treatments suggests the key roles these genes play in the tolerance of $D$. scoparium to abiotic stresses.

Acknowledgements: Financial support from RFBR and Cabinet of Ministers of the Republic of Tatarstan (No. 18-44-160031). 


\section{Statistical estimates of the transcription factor binding sites cluster in Arabidopsis and distant plant species genomes}

Orlov Y.L. ${ }^{1,2 *}$, Dergilev A.I. ${ }^{1}$, Dobrovolskaya O.B. ${ }^{2,3}$

${ }^{1}$ Novosibirsk State University, Novosibirsk, Russia

2 Peoples' Friendship University of Russia (RUDN University), Moscow, Russia

${ }^{3}$ Institute of Cytology and Genetics, SB RAS, Novosibirsk, Russia

*email: orlov@bionet.nsc.ru

The development of high-performance sequencing technologies allows to study the binding sites of protein transcription factors in genome scale. The clusters of transcription factor binding sites determine regulatory gene networks and evolutionary patterns. The growth of data volume on the experimentally determined binding sites raises qualitatively new problems for the analysis of gene expression, determining target genes for transcription factors. However, such data were not investigated in plant genomes in detail comparing to mammalian genomes. Plant genomes remain an insufficiently studied object, although they have complex molecular regulatory mechanisms of gene expression and response to the environmental stresses. It is important to develop new software tools for the analysis of the transcription factor binding sites location, their clustering in a model genome, visualization, and statistical estimates for such clusters. The existence of non-random clusters of the binding sites for 3 and more different factors identified by ChIP-seq was shown previously. Such clusters of sites could be used for gene promoter and enhancer prediction. This work presents a new application for the analysis of transcription factor binding sites in several evolutionarily distant model plant organisms. This work presents the applications of computer scripts to analyze ChIP-seq data, description of clusters and visualization in the heatmaps format. We used ChIP-seq profile peaks to study the transcription factor binding in three plants, including Arabidopsis thaliana, Physcomitrella patens, and Chlamydomonas reinhardtii. We discussed statistical estimates of the binding sites clusters found. The nonrandom clusters of binding sites in the investigated plant genomes are shown; and binding clusters in Arabidopsis were considered in more details including gene ontology and functional annotation. 


\title{
Molecular-cytological analysis of common wheat lines with Triticum dicoccoides genetic material
}

\author{
Orlovskaya O.A. ${ }^{1 *}$, Leonova I.N. ${ }^{2}$, Solovey L.A. ${ }^{1}$, Dubovets N.I. ${ }^{1}$ \\ ${ }^{1}$ Institute of Genetics and Cytology NAS of Belarus, Minsk, Belarus \\ ${ }^{2}$ Institute of Cytology and Genetics, SB RAS, Novosibirsk, Russia \\ * email: O.Orlovskaya@igc.by
}

Wild emmer wheat ( $T$. dicoccoides Schweinf., AABB, $2 n=28)$ is characterized by resistant to many diseases and abiotic stressed factors, and is possessed high quality of the grain. The particular interest in this species as a donor of valuable traits is due to its close relationship with $T$. aestivum (both genomes of the wild emmer are homologous to the corresponding genomes of $T$. aestivum (AABBDD, $2 n=42)$ ), which facilitates the transfer of the target genes into the wheat. Hybrid wheat lines were obtained from crossing common wheat varieties with $T$. dicoccoides to enrich wheat gene pool with favorable genes. The aim of this study was to analyze the nature of alien introgression and their influence on the cytological stability of hybrid lines. C-banding, SSR- and SNP-analysis were used to assess the genomic composition of the lines. C-banding allowed to identify introgressions of $T$. dicoccoides genetic material in the common wheat genome in the form of whole chromosomes with a clear predominance of the Bgenome chromosomes $(6 \mathrm{~A}, 1 \mathrm{~B}, 2 \mathrm{~B}, 3 \mathrm{~B}, 5 \mathrm{~B})$. In only one line, alien chromatin was found in the form of chromosomal arms $\left(7 \mathrm{BS}^{\mathrm{d}}\right.$ and $\left.4 \mathrm{AL}^{\mathrm{d}}\right)$. Molecular methods showed the presence of a large number of $T$. dicoccoides fragments (9-12) in both genomes of the studied wheat line. The introgression of the B-genome genetic material of the wild species was carried out mainly in the form of whole arms or large fragments, while the insertions of the A-genome were less extended. The highest frequency of the introgressed fragments was observed in chromosomes 1A, 1B, 2B, 3B. Analysis of microsporogenesis revealed a high level of bivalent chromosome pairing (close to $100 \%$ ) and the meiotic index $(86,2-93,0 \%)$ in most lines. Introgression lines characterized by normal meiosis will be used for identification of genes determining resistance to biotic and abiotic factors and high grain quality in order to developed donor lines for breeding. Acknowledgements: The study was supported by BRFFR (projects B18R-028, B20R240) and RFBR (project No. 18-516-00001). 


\title{
Transgenic poplar expressing AtGA20ox 1 demonstrate fast growing phenotype
}

\author{
Pavlichenko V.V.*, Protopopova M.V., Voinikov V.K. \\ Siberian Institute of Plant Physiology and Biochemistry SB RAS, Irkutsk, Russia \\ *email:vpavlichenko@gmail.com
}

Genes encoding key enzymes of gibberellins biosynthesis were shown as an effective tool for transgenesis aiming at fast-growing plant development. By the present study, we show one more successful genetic transformation by gibberellin-20-oxidase gene resulting in a specific phenotype. Populus berolinensis Dippel, the hybrid of laurel-leaf poplar (P. laurifolia) and black poplar ( $P$. nigra), was chosen as an object for the genetic transformation. We used GA20oxl CDS from Arabidopsis thaliana cDNA for agrobacterium mediated transformation of Populus berolinensis using pBI121 binary vector system. The nutrient media for regeneration and micropropagation was based on $1 / 2$ MS with full norm of microelements and Fe-chelate and contained the following components: thiamine $\left(1 \mathrm{mg} \mathrm{L}^{-1}\right)$, pyridoxine $\left(0.5 \mathrm{mg} \mathrm{L}^{-1}\right)$, nicotinic acid $\left(0.5 \mathrm{mg} \mathrm{L}^{-1}\right)$, sucrose $\left(20 \mathrm{~g} \mathrm{~L}^{-1}\right)$ and agar $\left(7 \mathrm{~g} \mathrm{~L}^{-1}\right)$. The acidity of the media was adjusted to $\mathrm{pH}$ 5.7. Only one type nutrient media supplemented with BAP $\left(0.2 \mathrm{mg} \mathrm{L}^{-1}\right)$, thidiazuron (TDZ) $\left(0.02 \mathrm{mg} \mathrm{L}^{-1}\right)$, NAA $\left(0.01 \mathrm{mg} \mathrm{L}^{-1}\right)$ was used for the regeneration of transgenic plants. As a result of micropropagation on selective nutrient media containing kanamycin $(50 \mathrm{mg}$ $\left.\mathrm{L}^{-1}\right)$ and cefotaxime $\left(250 \mathrm{mg} \mathrm{L}^{-1}\right), 15$ different transgenic lines were selected. The absence of $A$. tumefaciens contamination in plants was checked by incubation of leaves parts on the YEB nutrient media. Transgenesis was proved by rooting in the presence of kanamycin in the nutrient media and by PCR for both nptII and AtGA20oxl genes. Obtained transgenic plants are characterized by small narrow leaves, long and thin internodes and at least $300 \%$ faster growing in comparison to control plants. 25 days old test tube rooted plants had a very soft and easily bendable stem. Some plants had a spring-shaped stem, that may raise the problem with following pot or even field growing. Present phenotypic effects are shown for the test tube culture and additional experiments with pot-plants are required.

Acknowledgements: The study was partially supported by Russian Science Foundation (project No. 19-76-00033). 


\title{
Development of a marker panel for genotyping of soybean cultivars by genes controlling the flowering time and response to the photoperiod
}

\author{
Perfil'ev R.N. ${ }^{1,2 *}$, Shcherban A.B. ${ }^{1}$, Salina E.A. ${ }^{1}$ \\ ${ }^{1}$ Institute of Cytology and Genetics, SB RAS, Novosibirsk, Russia \\ ${ }^{2}$ Novosibirsk State University, Novosibirsk, Russia \\ * email: PerfilyevRN@bionet.nsc.ru
}

Soybean is a short-day plant with a very strong reaction to the day length. The duration of daylight hours most strongly affects the interfacial period between seedlings and flowering. This phase of growth and development is critical and determines the future maturity of the variety. A large number of genes and QTLs controls the photoperiod response. For genes with the strongest effect $E 1, E 2, E 3, E 4$ and with the least effect $E 9$, GmFT5a, the molecular structure and natural alleles, which cause variations in the growing season, were determined. All this makes it possible to develop and use allelespecific molecular markers for these genes in order to study the gene pool and marker assisted selection. For these purposes, we have developed an expanded panel of PCR molecular markers for the indicated genes and their most common alleles. The panel consists of original PCR markers for genes E1 and GmFT5a, and known PCR markers for other genes. When developing original PCR markers, the allele in the cultivars was additionally, define by sequencing the site with the allele-determining nucleotide substitution. Using this panel, 10 promising varieties of Russian and foreign selection were genotyped. Varieties from the collection of the Siberian Research Institute of Forage with a group of maturity from MG 0 to MG 000 The obtained genotype data will allow us and other breeders to use this information to select parental pairs when crossing, taking into account the possibility of achieving the required genotype in the offspring. The developed original PCR markers will make it possible to distinguish functionally different alleles in the E1 and GmFT5a genes. In general, the expanded panel of molecular markers will allow highly efficient marker assisted breeding to create varieties with the required maturity group.

Acknowledgements: This work was done within the framework of State Assignment Kurchatov Genomic Center of the Institute of Cytology and Genetics, SB RAS (075-152019-1662). 


\title{
Generalization of the results on the effect of selenium nanocomposites on the interaction of potatoes with the ring rot disease pathogen
}

\author{
Perfileva A.I.*, Nozhkina O.A., Graskova I.A. \\ Siberian Institute of Plant Physiology and Biochemistry, Siberian Branch, Russian Academy of Sciences, \\ Irkutsk, Russia \\ *email: alla.light@mail.ru
}

Selenium plays an important role in plants. It is present in a number of redox enzymes as a cofactor, takes part in the formation of chlorophyll, synthesis of tricarboxylic acids, in the metabolism of long-chain fatty acids. It has an antagonistic effect on the absorption and transport of heavy metals, increases resistance to water stress, salt and drought resistance. In addition, selenium is involved in the synthesis of tocopherols, tocotrienols, and ubiquinones. Direct transformations of selenium compounds in a plant cell occur in chloroplasts (synthesis of selenocysteine from selenite) and cytoplasm (synthesis of selenomethionine and selenocysteine). Many studies have been carried out to study the effect of nanocomposites of selenium on plant growth and development, as well as their ability to resist stresses of various nature.

We are studied the biological activity of nanocomposites of selenium in natural polymer matrices (carrageenan, arabinogalactan, starch). It was revealed that these agents reduce the viability of the phytopathogenic bacterium Clavibacter sepedonicus (reduces cell viability and their ability to form biofilms) and phytopathogenic fungi of the Phytophthora. Some of the studied chemically synthesized nanocomposites stimulate the growth and development of potatoes in vitro, the germination of seeds of cultivated plants (soybeans, peas, potatoes). Experiments in plants have shown a stimulating effect from nanocomposites on the plant biometric indicators and a decreased harmful effect from bacterial infection. Nanocomposites activate the antioxidant system of plant cells, affect the activity of peroxidase and products of lipid peroxidation. X-ray microanalysis was shown that after the treatment of plants with nanocomposites, selenium did not accumulate in plant tissues. In addition, chemically synthesized nanocomposites based on natural polymer matrices did not inhibit the viability of soil microorganisms Acinetobacter guillouiae, Rhodococcus erythropolis, Pseudomonas oryzihabitans, which indicates a relative safety for real use. These results allow us to consider nanocomposites as a plant development stimulator for agricultural crops. 


\title{
Alloplasmic lines (Hordeum vulgare)-Triticum aestivum with complete cytonuclear compatibility are the sources of introgression DH lines for wheat breeding
}

\author{
Pershina L.A. ${ }^{1,2 *}$, Trubacheeva N.V. ${ }^{1,2}$, Belan I.A. ${ }^{3}$, Rosseeva L.P. ${ }^{3}$ \\ ${ }^{1}$ Institute of Cytology and Genetics, SB RAS, Novosibirsk, Russia \\ ${ }^{2}$ Kurchatov Genomic Center of the Institute of Cytology and Genetics, SB RAS, Novosibirsk, Russia \\ ${ }^{3}$ Omsk Agricultural Scientific Center, Omsk, Russia \\ *pershina@bionet.nsc.ru
}

\begin{abstract}
Alloplasmic lines are considered as an additional source of diversity of cultivated plants, since when the cytoplasm is replaced by an alien one, new intergenomic interactions arise, leading to variability of adaptive and agronomically important traits. In our works, using the alloplasmic recombinant lines (H. vulgare)-T. aestivum, it was shown that only lines carrying alien cytoplasm with a complete process of cytonuclear coadaptation can be used in breeding. In such lines, cytonuclear compatibility was not disturbed under in vitro conditions, as well as during introgression of alien germplasm into the nuclear genome. Based on the analysis of the regions of mitochondrial and chloroplast DNA, as well as the influence of individual chromosomes on the fertility of alloplasmic lines, markers were identified that allow us to distinguish between alloplasmic recombinant lines with incomplete and complete cytonuclear compatibility. It has been shown for the first time that alloplasmic lines (H.vulgare)-T.aestivum with incomplete cytonuclear compatibility are suitable models for identifying chromosomes carrying restorer fertility genes $(R f)$ of bread wheat $T$. aestivum with $H$. vulgare cytoplasm. On the basis of alloplasmic recombinant introgression lines $(H$. vulgare)-T. aestivum with complete cytonuclear compatibility, DH lines were obtained, which were successfully used in breeding to obtain new promising breeding material [1] and commercial varieties of spring bread wheat. Examples of such varieties for which patents have been obtained: Sigma, Uralosibirskaya 2, Ishmskaya 11 [2] and the Sakmara variety is being tested in the State Variety Trial.

Acknowledgements: This work was supported by project No. 0259-2021-0018, RFBR grant No. 20-016-00196 and the Kurchatov Genomic Center of the Institute of Cytology and Genetics, SB RAS according to the agreement with the Ministry of Education and Science RF, No. 075-15-2019-1662.
\end{abstract}

\section{References}

1 Pershina L., Trubacheeva N., Badaeva E., Belan I., Rosseeva L. Study of androgenic plant families of alloplasmic introgression lines (H. vulgare) $T$. aestivum and the use of sister DH lines in breeding. Plants (Basel). 2020;9:764-816. DOI: 10.3390/plants9060764.

2 Pershina L.A., Belova L.I., Trubacheeva N.V., Osadchaya T.S., Shumny V.K., Belan I.A., Rosseeva L.P., Nemchenko V.V., Abakumov S.N. Alloplasmic recombinant lines (H. vulgare)T. aestivum with 1RS.1BL translocation: initial genotypes for production of common wheat varieties. Vavilov J. Genet. Breed. 2018;22:544-552. DOI: 10.18699/VJ18.393. 


\title{
The anther culture response in wheat (Triticum aestivum $\mathbf{L}$.) varieties and hybrids
}

\author{
Petrash N.V. ${ }^{*}$, Fedorova O.V. ${ }^{2}$ \\ ${ }^{1}$ Institute of Cytology and Genetics, SB RAS, Novosibirsk, Russia \\ ${ }^{2}$ FSBEI HE Novosibirsk SAU, Novosibirsk, Russia \\ *email: pnv11@bionet.nsc.ru
}

The Anther culture (AC) in wheat is the most effective method to obtain doubled haploid plants (DH), which successfully used for crop breeding programs, molecular and genetical studies. A genotype is one of the most important factors in determination response of the anther culture in wheat. Efficiency of $\mathrm{AC}$ were analyzed according to the following parameters: number of productive anthers per 100 anthers (PA), number of callus/ ELSs per 100 anthers, green plants per 100 anthers (GP), albino plants per 100 anthers (AP) and number of total regenerated plants (TR). For induction of pollen callus/ELS are used N6 medium with $55 \mathrm{~g} / 1$ sucrose; $35 \mathrm{~g} / 1$ maltose; 1 or $2 \mathrm{mg} / 1$ 2,4-D; $0,5 \mathrm{mg} / \mathrm{l} \mathrm{kinetin;} 100 \mathrm{mg} / \mathrm{l} \mathrm{mio-Inositol;} 6 \mathrm{~g} / \mathrm{l}$ agar. For the regeneration process, the developed embryo-like structures (ELSs) and callus were transferred to B5 medium with $30 \mathrm{~g} / \mathrm{l}$ sucrose, $5 \mathrm{~g} / \mathrm{l}$ agar. Two wheat varieties (Obskay 2 and Novosibirskay 15) and their F1 and F2 progenies were used in this work. In general, for the Novosibirskaya 15 variety, there is a tendency for a higher anther culture response than for the second parental variety Obskaya 2. Thus, in Novosibirskaya 15, the number of PA, number of callus/ ELSs, TR and AP is about 1.5 times higher, and the value of GP exceed 2.5 times. The efficiency of anther culture of hybrid combinations was different; the parameters of F2 hybrids were like the higher parent, Novosibirskaya 15. The values of the traits F1 hybrid for callus/ ELSs, AP, GP were lower than higher parent and F2 and were like the lower parent Obskaya 2. The TR and the AP indicated significant differences (at $p<0.05$ ) between F1 and Novosibirskaya 15. According to the results of studying the influence concentration of the growth regulator 2,4-D to the anther culture response, it was found that the most effective concentration was $1 \mathrm{mg} / \mathrm{l}$.

Acknowledgements: This work was supported by Institute of Cytology and Genetics, SB RAS budget project No. 0259-2021-0018. 


\title{
Genomic features of oil model compounds biodegradation by Rhodococcus qingshengii strain VKM Ac-2784D
}

\author{
Petrushin I.S. ${ }^{1,2 *}$, Markova Y.A. ${ }^{1}$, Karepova M.S. ${ }^{1}$, Kudryavtseva Y.A. ${ }^{2}$, \\ Belovezhets L.A. ${ }^{3}$ \\ ${ }^{1}$ Siberian Institute of Plant Physiology and Biochemistry, Siberian Branch of the Russian Academy \\ of Sciences, Irkutsk, Russia \\ ${ }^{2}$ Irkutsk State University, Irkutsk, Russia \\ ${ }^{3}$ A.E. Favorsky Irkutsk Institute of Chemistry, Siberian Branch of the Russian Academy of Sciences, \\ Irkutsk, Russia \\ * email: ivan.kiel@gmail.com
}

Products of petroleum origin (oil and its components) are dangerous pollutants of the soil. Bacterial species of genus Rhodococcus have the ability to degrade a variety of hydrocarbons in contaminated soil and are useful for the bioremediation of polluted environments. We isolated the Rhodococcus qingshengii strain VKM Ac-2784D from the rhizosphere of couch grass (Elytrigia repens) which grows on oil-polluted site near Zalary, Irkutsk State, Russia (Belovezhets, 2017, 2020). This strain can effectively degrade oil and some model compounds (naphthalene, anthracene and phenanthrene). Such activity lowers the negative effect of soil pollution and recovers grow process of plants (Tretyakova, 2019). Although Rhodococcus spp. are well-known biosurfactant producers in temperate environments, the ability to synthesise surface-active agents is recognized as a general feature among cold-adapted microorganisms from this phylotype. We suggest that bioremediation activity of the strain in this study is associated with biosurfactants and phytohormones production.

This whole-genome shotgun sequence has been deposited at DDBJ/ENA/GenBank under the accession No. CP064920. We performed the search for biosynthetic gene clusters (BGCs) encoding secondary metabolites with web version 6.0 of antiSMASH and found 19 functional clusters (regions) on the chromosome. These gene clusters for heterobactin, ectoine, erythrochelin production, bacteriocin, ectoine, heterobactin A/heterobactin S2 (non-ribosomal peptide synthetase, NRPS). Ectoine may have a protectiverole, it helps bacteria to survive in extreme conditions (such as low temperatures and oil pollution).

The genomic features study of the Rhodococcus qingshengii strain VKM Ac-2784D helps to understand its hydrocarbons degrading mechanisms and broaden our knowledge about plant- bacteria interaction. 


\title{
Development of molecular markers for the identification of prolamins genes and their correlation with baking qualities of grain
}

\author{
Pirsikov A.S., Enzekrey E.S.*, Siksin S.V., Milyukova N.A. \\ All-Russia Research Institute of Agricultural Biotechnology, Moscow, Russia \\ * email: eynzeynkreyn@gmail.com
}

At the present time various molecular genetic markers are used for studies on biodiversity, phylogeny, and evolution. Storage proteins of cereals such as gliadins and glutenins are considered to be convenient markers of stable genes associations determinant baking qualities. That allows them to be used for solving practical problems. Effective molecular genetic markers have been developed for the identification of gliadin-encoding genes, that make it possible to establish the relationship of certain loci with the technological and nutritional qualities of triticale grain and significantly speed up the breeding process. The product amplification efficiency was confirmed by the presence of fragments of certain lengths and the absence of a PCR product in the negative control. According to literature data the size of the polyglutamine site play an important role in dough properties of triticale. The larger the polyglutamine site, the higher the quality of grain gluten, because large number of glutamine side chains is shown to increase visco-elasticity properties of dough. Based on the obtained results, it is impossible to make an definite conclusion of the amount of gliadins in a particular cultivar or line, since it is necessary to exclude pseudogenes by means of the cDNA syntesis. In the present study the bread-making quality analysis of diverse triticale genotypes was carried out. As a result three samples of spring triticale were isolated Lana, 131/714, and Grebeshok, which had the highest percentage of gluten content 21.3, 20.9 and 19.1\% respectively. Two of them (131/714; Grebeshok) in PCR analysis with primers Gli FII / Gli RII revealed an additional product. This fact requires further researchers.

Acknowledgments: The investigation was supported by the grant of the President of the Russian Federation No. MK-3235.2021.5. 


\title{
Genes of wheat resistant to leaf rust (Puccinia triticina) in Siberia and Far East in 2020 are the basis for determining the breeding strategy for stress resistance
}

\author{
Piskarev V.V. ${ }^{1 *}$, Sochalova L.P. ${ }^{1}$, Morozova E.V. ${ }^{1}$, Aparina V.A. ${ }^{1}$, Boyko N.I. ${ }^{1}$, \\ Sukhomlinov V.Yu. ${ }^{1}$, Poteshkina A.A. ${ }^{1}$, Aseeva T.A. ${ }^{2}$, Zenkina K.V. ${ }^{2}$ \\ ${ }^{1}$ Siberian Research Institute of Plant Production and Breeding - Branch of the Institute of Cytology and \\ Genetics, SB RAS, Novosibirsk, Russia \\ ${ }^{2}$ Khabarovsk Federal Research Center of the Far Eastern Branch of the Russian Academy of Sciences - \\ Far Eastern Agricultural Research Institute, Khabarovsk, Russia \\ * email: piskaryov_v@mail.ru
}

Creating disease-resistant cultivars is a highly effective and environmentally friendly way to protect crops from biotic stress. The population of Puccinia triticina evolves dependently with the host plant in time and space, resulting in a change in its genetic structure. Mutations, genetic recombinations, and spore migrations are the main factors of fungal variability. Leaf rust samples were collected in 2020 on the territory of Western Siberia (18 locations), Eastern Siberia (3), and Far East (1) to identify differences in the genetic structure of the populations located on the territory. A sample from the Far East was combined with samples from Eastern Siberia when describing the evaluation results. The population structure was studied in laboratory conditions on the leaf segments of isogenic Thatcher lines carrying resistance genes $(\operatorname{Lr} 1, \operatorname{Lr} 2 a, \operatorname{Lr} 2 c, \operatorname{Lr} 3 a, \operatorname{Lr} 9, \operatorname{Lr} 16$, Lr26, Lr3ka, Lr11, Lr17, Lr30, Lr19, Lr20, Lr14a, Lr18, Lr2b, Lr3bg, Lr14b, Lr15, Lr41, Lr45, Lr47) and varieties - Agent (Lr24) Tulaykovskaya 10 (Lr6Agi2), Tulaykovskaya 105 (Lr6Agil), CS2A/2M (Lr28), Pavon F76 (Lr47) and Chelyaba 75 (LrSp2). All samples (18-Western and 4 - Eastern) were virulent to the genes Lr1, Lr2a, Lr30 and Lr2b (damage - 3 points) and avirulent - Lr19, Lr41, Lr47, Lr24, Lr28, Lr6Agi1, Lr6Agi2 and LrSp2 (damage - 0-2 points). The virulence genes for $\operatorname{Lr} 2 k, \operatorname{Lr} 3 a$, Lr16, and $\operatorname{Lrll}$ were found in all samples from Eastern, as well as in 17, 16, 17, and 14 samples from Western Siberia respectively. The virulence gene to $\operatorname{Lr} 9$ was detected in 2 samples from the Altai region and one from the Kuibyshev district of the Novosibirsk region, the rest did not contain them. The Thatcher Lr26 line was affected in $50 \%$ of cases by both samples from Eastern and Western Siberia. Virulence to the Lr45 gene was very rare (a sample from the Suzunsky district of the Novosibirsk region and a sample from the Krasnoyarsk region). Virulence to the $L r 20$ gene was more common in Western Siberia (14 samples) than in Eastern Siberia (1 sample from the Krasnoyarsk region). Thatcher lines with the remaining resistance genes ( $L r 3 k a, L r 3 k g, L r 14 a, L r 14 b$, Lr15, Lr18) were characterized by polymorphic damage in both Western Siberia and Eastern. It should be noted that the Agent variety was damaged by the spores of two samples from the Omsk region and one from the Kuibyshev district (2 points resistance), which later allowed us to isolate and multiply 4 clones that damaged varieties with resistance determined by this gene (KWS Akvilon, Agent, Quintus, Cunningham, etc.) by 3-4 points (susceptibility).

Acknowledgments: The reported study was funded by RFBR, project number 20-01600093. 


\section{Progress of breeding strategies in winter rye: from mass selection to genomic selection}

Ponomareva M.L. ${ }^{2 *}$, Ponomarev S.N. ${ }^{1}$

${ }^{1}$ Tatar Research Institute of Agriculture, FRC Kazan Scientific Center of RAS, Kazan, Russia

${ }^{2}$ Laboratory of Plant Infectious Diseases, FRC Kazan Scientific Center of RAS, Kazan, Russia

*email: smponomarev@yandex.ru

Winter rye is great importance in the global economy and food traditions in 7 European countries, where this crop covers over more than 100 thousand hectares (Germany, Poland, Russia, Belarus, Denmark, Spain, Ukraine). According to FAOSTAT in 2019 the world rye grain production was 13 million tons, of which $81 \%$ were grown on the European continent with an average yield of $30.4 \mathrm{dt} / \mathrm{ha}$. The specificity of breeding programs in rye-growing countries including Russian Federation is due to the peculiarities of climatic conditions, soil fertility, and national traditions of consumers. The main breeding directions for the coming years remain the adaptability to unfavorable abiotic and biotic factors, increase of the yield, the targeted use of the final product and its high quality. Work in this direction has led leading winter rye producers in Europe to replace traditional population varieties with $\mathrm{F}_{1}$ hybrids on $60 \%$ of the area. In rye breeding, three main methods are used to form a new genetic pool: selection in existing populations, recombination and induction of mutations. In recent years, rye genetics has evolved rapidly. Modern genomics-based techniques, like genome-wide association and/or linkage mapping should be applied. A large number of tasks of functional and structural genetics and rye genomics are solved with molecular markers, some of which have found their application in practical breeding. For rye, genomic selection, as opposed to marker-based, is a more promising methodology for rapid improvement of quantitative plant traits. The integration of modern technologies with conventional methods in rye breeding programs has significantly accelerated the time from first hybrid to cultivar release, while maintaining the increase of average yield and improving other traits such as biotic and abiotic stress resistances as well as quality. 


\title{
Molecular markers of the $S K r$ gene in the evaluation of bread wheat genotypes with different crossability with rye
}

\author{
Porotnikov I.V.*, Antonova O.Yu., Mitrofanova O.P. \\ N.I. Vavilov All-Russian Institute of Plant Genetic Resources (VIR), St. Petersburg, Russia \\ *email: i.v.porotnikov@gmail.com
}

Crossability of bread wheat (Triticum aestivum L.) with rye (Secale L.) is controlled by $K r 1-K r 4$ genes and suppressor $S K r$. The recessive alleles cause high crossability with rye, while the dominant ones suppress crossability. The genes $K r l$ and $S K r$ have a major effect on ability to set seed. They were located on 5BL and 5BS respectively. Molecular markers for these genes can force identification of new crossable genotypes and make the increasing of wheat's genetic diversity easier. The purpose of research is to study allelic variation for closely linked to $S K r$ molecular markers and to analyze their association with high crossability with rye. We used 77 crossable and 23 noncrossable genotypes of bread wheat from VIR collection, which were characterized in our experiments or according to literature sources. Every accession was represented by 2-3 genotypes. Three markers from literature: "gene 12", Xcfb341 and Xcfb382 were used for molecular screening. The diagnostic fragment of high crossability for marker "gene 12 " was identified among 90,9\% crossable genotypes, when for Xcfb341 - among $88,3 \%$. However, these fragments were also found in many noncrossable genotypes (43 and $43,5 \%$ respectively). The SSR marker $X c f b 382$ was monomorphic in almost all of genotypes, except for crossable genotypes from k-38587 Sibirka Yartsevskaya (Russia), which had the unique fragment. New alleles that weren't previously described in the literature were also identified at the $X c f b 341$ locus. In total, the six haplotypes were identified based on three markers. The major haplotypes were $\mathrm{H}^{\mathrm{SKr}}-1$ and $\mathrm{H}^{\mathrm{SKr}}-2$, which were found out for 77 and $18 \%$ genotypes respectively. Haplotype $\mathrm{H}^{\mathrm{SKr}}-1$ was revealed the most of crossable genotypes $(85,9 \%)$ and only $56,5 \%$ noncrossable genotypes had haplotype $\mathrm{H}^{\mathrm{SKr}}-2$. Other haplotypes were rare or unique. All of them were found in crossable genotypes. Thus, the use of molecular markers "gene12" and Xcfb341 showed a sufficiently high effectivity for identification of crossable genotypes. The additional markers are needed for more successful searching. 


\title{
Genomic introgressions of immune Vitis rotundifola Michx into Russian grapevine germplasm revealed by RADseq genotyping
}

\author{
Potokina E.K. ${ }^{1,2 *}$, Grigoreva E.A. ${ }^{1,2,3}$, Karzhaev D.S. ${ }^{1}$, Ulianich P.S. ${ }^{4}$, Volkov V.A. ${ }^{1,2}$, \\ Vasylyk I.A. ${ }^{2}$, Volynkin V.A. ${ }^{2}$, Likhovskoi V.V. ${ }^{2}$ \\ ${ }^{1}$ Saint-Petersburg State Forestry University, St. Petersburg, Russia \\ ${ }^{2}$ All-Russian National Research Institute of Viticulture and Winemaking “Magarach” RAS, Yalta, Russia \\ ${ }^{3}$ ITMO University, St. Petersburg, Russia \\ ${ }^{4}$ All-Russia Research Institute for Agricultural Microbiology, St. Petersburg, Russia \\ *email: e.potokina@yahoo.com
}

Vitis vinifera L. is the most widely cultivated grape species in the world, and its plantations occupy about $94 \%$ of the area of the commercial vineyards. Traditionally, vineyards are protected against a disease by spraying, which has a harmful effect on the environment. Breeding of varieties resistant to the most common pathogens would allow switching to a more environmentally friendly way of cultivating grapes. Wild species of Vitis are generally disease resistant, but produce poor quality products. Breeding allows to combine disease resistance with grape quality traits using strategy of remote hybridizations.

The most promising source of resistance genes is the North American species $V$. rotundifolia Michx, which belongs to the subgenus Muscadiana Panch. Interspecific crosses of cultivated grapes with this species are extremely difficult, due to the different number of chromosomes. However, as a result of very few successful attempts, some interspecific hybrids with a stable karyotype were obtained in the beginning of the century. In 2011 their BC5 progenies have been involved into the breeding programs of "Magarach" Institute. Due to the lack of information about introgressed resistance loci and their localization on chromosomes, the breeding work is carried out "blindly", not allowing to manipulate by gene combinations to create genotypes resistant to the most dangerous diseases - downy and powdery mildew.

To solve the problem, 142 breeding lines from three half-sibling grape populations, carrying introgressions from $V$. rotundifolia, were "genotyped by sequencing" using RADseq method. In total, 309,762,340 high quality Illumina reads were generated. The sequencing data were aligned to the public available $V$. vinifera $12 \mathrm{X}$ genome assembly for SNP calling procedure. SNP calling was performed using Tassel V.5.2.40 and Stacks V. 2.53 bioinformatic software, yielding 45 thousands SNP per population. 12734 SNPs were shared between all three populations.

The genotyping data allowed to reveal a scheme of chromosome maps for each line, where introgressions of foreign material - fragments of the $V$. rotundifolia genome were located. Then, the introgressed regions of chromosomes that affect the variability of agrobiological and resistance traits will be decoded by sequencing to identify potential candidate genes.

Acknowledgements: The research was supported by the Russian Science Foundation (Project No. 20-16-00060). 


\title{
Evolution of MLO-like proteins in flowering plants
}

\author{
Pozharskiy A.S. ${ }^{1,2 *}$, Gritsenko D.A. ${ }^{1,2}$ \\ ${ }^{1}$ Institute of Plant Biology and Biotechnology, Almaty, Kazakhstan \\ ${ }^{2}$ Al-Farabi Kazakh National University, Almaty, Kazakhstan \\ *email: aspozharsky@gmail.com
}

MLO-like proteins (MLP) are the family of transmembrane proteins in plants. The first MLP was discovered in barley as a factor of susceptibility to mildew, and its numerous homologs were found in various groups of plants, from algae to angiosperms. Studies have shown contribution of MLP to susceptibility to fungal and bacterial diseases in other species as well, including Arabidopsis thaliana, Solanum lycopersicum, etc. MLP are assumed to be targets for specific plant-pathogen interactions, and loss-of-function mutations have been shown to increase resistance to corre. The scope of the present work is to investigate phylogenetic relations across wide range of MLP sequences known up to date.

MLP sequences belonging to green plants were retrieved from UniProt database and preliminary clustered using CD-HIT with similarity threshold $50 \%$. In order to exclude individual highly variable proteins, only proteins included into clusters with 10 or more sequences were selected for further analysis (2749 in total). The final set of sequences included MLP from flowering plants and 5 accessions from gymnosperms as an outgroup. Analysis included multiple sequence alignment (MAFFT), identification and selection of conserved regions (UGENE), building Maximum Likelihood (MEGA-X) and Neighbor-Joining trees (R/phangorn), motif search (MEME).

Tree structures revealed by ML and NJ methods were consistent between each other. Groups of homologs were observed at the different taxonomic levels. Three principal clusters and five sub-clusters were observed at the level of angiosperms in general. Inside sub-clusters a clear distinction between super-order clades and to some extent between orders was observed. Positions of the most represented orders were in accordance to their known phylogeny (APG IV). Characteristic amino-acid motifs were found to describe distinct clusters and sub-cluster groups.

Revealed phylogenetic structure can be useful for classification of MLP family across wide range of plant species. Distinction of parallel orthologous lines will help to put existing studies of MLP and their impact on plants into wider systematic context. 


\title{
Identification and structural features analysis of long noncoding RNAs
}

\author{
Pronozin A.*, Afonnikov D. \\ Kurchatov Genomic Center of the Institute of Cytology and Genetics of Siberian Branch of the Russian \\ Academy of Sciences, Novosibirsk, Russia \\ * email: pronozinartem95@gmail.com
}

Motivation and Aim: Long non-coding RNAs (lncRNAs) are typically defined as transcripts of more than 200 nucleotides length and without any protein coding potential. The functions are poorly understood, however, a number of well-known plant lncRNAs play diverse roles in $\mathrm{X}$ inactivation, imprinting and gene expression. Thus lncRNAs are involved in important plant development processes such as phosphate homeostasis, flowering, photomorphogenesis and stress response in this connection, their study is relevant. Information is obtained from transcriptomes, but bioinformatic annotation methods are not sufficiently presented, especially for plants. This raises the challenge of developing approaches to automatic annotation and prediction of lncRNA functions in plants.

Methods and Algorithms: In this paper a computational pipeline for the identification and annotation of lncRNA in the plant transcriptome has been developed, steps:

1. Identification of lncRNAs - lncFinder [1].

2. Alignment lncRNA on referense genome - GMAP [2].

3. IncRNAs classification - gffcompare [3]. IncRNAs structural features analysis. The pipeline is implemented using the Snakemake workflow management system language. Results: The pipeline was used to analyze $~ 800$ Zea mays transcriptomes comprising 3148430 transcripts in total. We identified 2741504 (87\%) lncRNAs; of them $98 \%$ were aligned to the reference genome. We identified 334069 exon antisense, 4390 intron antisense, 231970 multi-exon, 81163 retained introns, 512753 intergenic. Antisense lncRNAs alignment (exon, intron, 338459 tr.) on structure of the target gene, showed that the predominant amount of lncRNA is aligned on exon 1 of the target gene.

Conclusion: The proposed pipeline made it possible to identify 1164345 new lncRNAs in the maize genome, annotate them and evaluate their structural features.

Acknowledgements: Work was funded by the Kurchatov Genomic Center of the Institute of Cytology and Genetics, SB RAS, agreement with the Ministry of Education and Science of the Russian Federation No. 075-15-2019-1662.

\section{References}

1 Han S. et al. LncFinder: an integrated platform for long non-coding RNA identification utilizing sequence intrinsic composition, structural information and physicochemical property. Briefings in Bioinformatics. 2019;20(6):2009-2027.

2 Wu T. D., Watanabe C. K. GMAP: a genomic mapping and alignment program for mRNA and EST sequences. Bioinformatics. 2005;21(9):1859-1875.

3 Pertea G., Pertea M. GFF utilities: GffRead and GffCompare. F1000Research. 2020;9. 


\title{
Locus $\mathrm{Hl}$, determining leaf pubescence in the genus Triticum $\mathrm{L}$., as a marker of non-homoeological rearrangement $4 \mathrm{~A} / 5 \mathrm{~A} / 7 \mathrm{~B}$, its phenotypic expression and role in adaptation to drought
}

\author{
Pshenichnikova T.A. ${ }^{1}{ }^{\text {, }}$ Simonov A.V. ${ }^{1}$, Smirnova O.G. ${ }^{1}$, Permyakov A.V. ${ }^{2}$, \\ Permyakova M.D. ${ }^{2}$, Osipova S.V. ${ }^{2}$ \\ ${ }^{1}$ Institute of Cytology and Genetics, SB RAS, Novosibirsk, Russia \\ ${ }^{2}$ Siberian Institute of Plant Physiology and Biochemistry, Irkutsk, Russia \\ * email: wheatpsh@bionet.nsc.ru
}

Chromosomal translocations largely determine the formation of plant genomes in the course of evolution. |Translocations often lead to genomic disruptions and are unfavorable for a survival of an individual plant. On the other hand, the genes that have undergone translocations within genome can demonstrate an increased rate of evolution and changes in their functional potential. The most known and widespread translocation in hexaploid wheat is the non-homeologous translocation involving 4A, 5A, and 7B chromosomes. The translocation 4A/5A already existed in the diploid genome $\mathrm{A}$ of Triticum urartu and T. monococcum, and thus preceded the first polyploidization resulted in the formation of tetraploid wheat. The translocation 7B/rearranged $4 \mathrm{~A}$ appeared in tetraploid wheat, suggesting its origin during the second polyploidization that produced a hexaploid wheat. The long-term existence of this rearrangement in the genomes of wheat of different ploidy may indicate its adaptive significance. With the help of isogenic and substitution lines of bread wheat - carriers of leaf pubescence genes $\mathrm{Hl}^{t t}$ and $H \mathrm{H}^{\text {aesp }}$ in chromosomes $5 \mathrm{~A}$ and 7B from related species, we have shown that this rearrangement can be associated with this important adaptive trait. The intrachromosomal position of $\mathrm{Hl}^{t t}$ and $H \mathrm{H}^{\text {aesp }}$ genes, marked with microsatellite markers, corresponds to the regions of the rearrangement. The phenotypic manifestation of the two genes is very similar and results in the formation of long, sparse trichomes. The phenotypical effect on agronomically important traits was also identical. Another type of pubescence, widespread among bread wheat cultivars and controlled by Hll gene, was previously mapped to $4 \mathrm{~B}(4 \mathrm{~A})$ chromosome. The phenotypic expression of this gene is significantly different from the other two genes. It is possible that its functional difference is related to its more ancient origin.

Acknowledgements: This work was supported by the budget project No. 0259-20210018. 


\section{Field evaluation of different wheat-alien amphiploids in the conditions of the Absheron Peninsula (Azerbaijan)}

Rahimov R.G.*, Akparov Z.I., Abbasov M.A., Aliyeva A.J., Mehdiyeva S.P. Genetic Resources Institute of ANAS, Baku, Azerbaijan

*email: rahimov.rg@gmail.com

Many wheat-alien amphiploids derived from hybridization of wheat with its wild relatives and considering as bridges for introducing alien genes into wheat cultivars as well as the valuable research material for genetic investigation of many traits. In our study the field trials were carried out to evaluate agronomic performance of the diverse wheat-alien amphiploids during the period of 2016 to 2020 in the conditions of the Absheron Peninsula (Azerbaijan). A set of the 16 wheat-alien amphiploids used in the present study obtained mainly from collections of different countries (USA, Spain, Mexico and Russia) as well as locally and comprised of 6 tritirigia genotypes (T. aestivum / Ag. junceum, T. aestivum / Ag. distichum, T. aestivum / Ag. intermedium, T. aestivum / Ag. ponticum, T. aestivum cv. Chinese Spring / Ag. scirpeum, T. aestivum cv. Chinese Spring / Ag. elongatum), 5 wheat-barley genotypes (HT-621(H. chilense / T. turgidum), HT471 (H. chilense / T. turgidum), Triticum timopheevii subsp. timopheevii / Critesion bogdanii, Bulel (T. turgidum / H. chilense), Aucan (T. turgidum /H. chilense)), 2 wheat-Elymus lines (Triticum sp. / Elymus arenarius, Elymus ciliaris / T. aestivum subsp. aestivum cv. Inayama comugi), 2 secondary triticale genotypes (AD 908, PRAG 244) and a wheat-dasypyrum genotype (T. turgidum / Haynaldia villosa). The aim of this field assessment was to get data on morphological and physiological traits of these amphiploids for their expected use in different hybridization procedures as initial parent material. Stability on morphological and physiological traits were observed in all studied wheat-alien amphiploids except for three genotypes T. aestivum / Ag. distichum, HT471 and T. turgidum / Haynaldia villosa. 


\section{Melanin from the lichen Lobaria pulmonaria: physicochemical properties and biological activity}

Rassabina A.E. ${ }^{1 *}$, Khabibrakhmanova V.R. ${ }^{1,2}$, Leksin I.Y. ${ }^{1}$, Minibayeva F.V. ${ }^{1}$

${ }^{1}$ Kazan Institute of Biochemistry and Biophysics, FRC Kazan Scientific Center of the RAS, Kazan, Russia

${ }^{2}$ KNITU, Kazan, Russia

*email: AERassabina@yandex.ru

Symbiotic lichens are of a great interest for research, as they display high stress resistance. Currently, the chemical composition of many lichens has been determined, and some metabolites involved in the response to stresses have been identified. Melanins can protect lichens from UV radiation and high light, however their chemical structure, physicochemical properties, and genes responsible for melanin synthesis in lichens are not studied yet. So far, only a limited number of lichens, including Lobaria pulmonaria, have their genome sequenced. We studied the structure, elemental composition, functional groups, paramagnetic and antioxidative properties of UV inducible melanin in L. pulmonaria and correlated these parameters with expression of the genes involved in melanin biosynthesis. According to the chemical structure of the monomer link, these high-molecular weight pigments are classified into eumelanin, allomelanin, pheomelanin and other types. Melanin extracted from L. pulmonaria contains C 49.6\%, $\mathrm{O} 40.2 \%, \mathrm{H} 5.8 \%, \mathrm{~N} \mathrm{4.4 \%}$. Using UV and FTIR spectroscopy, we showed similarity of its chemical properties to those of the commercial eumelanin from Sepia officinalis. When studying the paramagnetic properties of extracted melanin by EPR spectroscopy, a signal corresponding to the free electron signal was registered, and the content of paramagnetic centers was determined as $0.64 \times 10^{17} \mathrm{spin} / \mathrm{g}$. Lichen melanin showed antioxidative activity against the DPPH radical with $\mathrm{IC}_{50} 273 \mu \mathrm{g} / \mathrm{ml}$. Interestingly, upregulation of genes responsible for both eumelanin and DHN melanin was found in L. pulmonaria in response to UV-B exposure. These are genes encoding tyrosinases, multicopper oxidases for eumelanin and polyketide synthases, THN-dehydrogenases, scytalon dehydrogenases for DHN melanin. In conclusion, melanins synthesized by extremophilic lichens protect against UV radiation, oxidative stress, intoxication by heavy metals and xenobiotics. Therefore, lichen melanins have clear biotechnological perspectives in bioremediation and pharmacy.

Acknowledgements: The work was supported by the RSF grant (No. 18-14-00198) and the RFBR grant "Postgraduates" (No. 20-34-90044). 


\title{
Fungal metagenome of Chernevaya Taiga soils: taxonomic composition, differential abundance and factors related to plant gigantism
}

\author{
Rayko M. ${ }^{1 *}$, Sokornova S. ${ }^{2}$, Lapidus A. ${ }^{1}$ \\ ${ }^{1}$ Center for Algorithmic Biotechnology St. Petersburg State University, St. Petersburg, Russia \\ ${ }^{2}$ All-Russian Institute of Plant Protection, Saint-Petersburg, Russia \\ * email:m.rayko@spbu.ru
}

Chernevaya taiga of Western Siberia is a unique complex ecosystem, distinguished by extremely high vegetation, the reasons for which are poorly understood.

In this study we explored the fungal diversity of the chernevaya taiga soils in Novosibirsk and Tomsk regions in comparison with other soil types as fungal component (namely, mycorrhizal fungi) can serve as a one of the factors of high soil productivity.

Fungal components of soil biome of chernevaya taiga and control regions were investigated using ITS rRNA sequencing. We compared soil samples at two key locations in the chernevaya taiga of Salair and in the grass pine forest on the ancient terraces of the Ob River, collected in summer and fall 2019 and spring 2020. The taxonomic analysis revealed predominant fungal phyla in chernevaya taiga regions. The results demonstrate that the fungi of the chrenevaya taiga regions have higher species diversity (Faith's PD) vs control soils, and the diversity is due more to the sampling sites rather than to the seasons (Bray-Curtis distance). We studied most differentially abundant taxa between soil types, and annotated taxa by ecological guilds and trophic types. The most differentially abundant taxa in summer and fall chernevaya taiga samples belong to the phylum Glomeromycota - arbuscular mycorrhizal symbiotrophs, which are known to establish symbiotic relationships and enhance the plan growth. Also, several OTUs were assigned to novel genera in the Glomeraceae and Claroideoglomeraceae family (absent in UNITE fungal ITS database). These potential novel genera deserve further study because arbuscular mycorrhizal fungi usually can not be cultivated. Our findings add potential explanation on the high productivity and plant gigantism in chernevaya taiga, and expand our knowledge of fungal biodiversity.

Acknowledgements: The reported study was funded by Russian Scientific Foundation (grant ID 19-16-00049). 


\title{
The effect of "early"protein of papillomavirus HPV16 E2 made in plant expression system on the base of tomato fruit on tumor formation in mice infected with cancer HeLa cells
}

\author{
Rekoslavskaya N.I.*, Salyaev R.K., Stolbikov A.S. \\ The Siberian institute of plant physiology and biochemistry of the Siberian branch of Russia Academy \\ of Sciences, Irkutsk, Russia \\ * email: rekoslavskaya@sifibr.irk.ru
}

The plant expression system was developed for purposes of the synthesis of the heterologous protein HPV16 E2 (and others) in tomato fruits. The sequence of the RNA replicase of the simple plant retrovirus (Cucumber mosaic virus) RdRP CMV (the gene RNA 2a) was inserted into genetic construct which contained the sequence of the antisilencer protein encoded by conjugated gene RNA $2 b$ either. As a whole, the construct was presented as followed: $R B$->p35S RdRP $(2 a+2 b)$->p35S hpv16 E2 t35S$>L B$, in which both promoters $\mathrm{p} 35 \mathrm{~S}$ were placed as two nonhomologous sequences. The synthetic yield of the protein of interest HPV16 E2 was as high as 25-30\% of the total soluble protein (up to $300 \mathrm{mkg}$ per $1 \mathrm{mg}$ of TSP). This amount of HPV16 E2 synthesized allowed to use transgenic tomato fruit as vaccine material for mice vaccination without any preliminary purification. To rise antibodies in mice blood serum, mice were vaccinated per os with vaccine material of tomato fruit transgenic with the gene hpvl6 E2 for 3-4 times (in different experiments) and after one month from last vaccination, samples of blood were collected and used for the analysis of antibodies in serum. To evaluate the aftereffect of the vaccination, the rest part of vaccinated mice have been stayed alive for sufficiently long time (more than one year). It was found that vaccinated mice long lived and were very active (there were almost no deaths). The content and quality of antibodies to HPV16 E2 from blood serum of vaccinated mice were analysed by Elisa and Western blot hybridisation. It was shown that antibodies raised to HPV16 E2 in blood of vaccinated mice have higher titer and significantly prominent avidity in comparison to commercial antibodies of the Abcam company (UK) developed to E2vaccinia conjugated with the protein binding of maltose after intravenous administration to mice. The HPV16 E2 protein is the main regulatory protein of the expression, replication and releasing in the live cycle of papillomavirus. The gene encoded HPV16 E2 is placed within the promoter of "early" genes $h p v$ E6 and $h p v$ E7 encoded oncogenes HPV E6 and HPV E7 and played the role of the supersupressor of the expression of these genes. HPV16 E2 is absent in tumors because of the degradation during the integration of papillomavirus. Therefore it was very significant to appreciate the action of this protein on tumors appeared in mice after the injection of cancer HeLa cells in hips. Conventional laboratory mice (male and female at the age of 6 months) were infected with $100 \mathrm{mkl}$ of the suspension of HeLa cells into hips. After $1 \mathrm{month}$, the appearance of lung tumors in both females and males as well testis tumors in males were observed. Oral administration of vaccine material with HPV16 E2 in transgenic tomato fruit to mice caused the regression of tumors both in lungs of males and females and the siginificant decrease of the size of tumors of testis in males. The regression of tumors was accompanied by the increase of contents of $\mathrm{T}$ cell receptor, interferon, CD8+ and CD4+ T lymphocytes as well apoptotic enzymes: granzyme B, perforin and granulysin in blood serum and splenocytes according to Elispot analysis. 


\section{Efficient formation of adventitious shoots from immature zygotic embryos of the oilseed crop camelina}

Rezaeva B.*, Kumlehn J.

Leibniz Institute of Plant Genetics and Crop Plant Research (IPK) Gatersleben, Plant Reproductive Biology, Gatersleben, Germany

*email: rezaeva@ipk-gatersleben.de

Camelina (Camelina sativa (L.) Crantz) is an oilseed plant that tolerates various adverse conditions, such as low temperature, drought, and nutrient-poor soils. In addition, the unique fatty acid profile of its seeds renders camelina particularly suitable for the provision of food and health products. While genetic engineering may greatly contribute to the improvement of yield and seed composition, it is dependent on efficient plant regeneration from cells that are accessible to DNA transfer, be it by employing Agrobacterium or by means of direct DNA delivery. In camelina, the current limits in plant regeneration constitute a bottleneck for the development and application of conventional as well as site-directed genetic engineering in elite germplasm. In the present investigation, immature zygotic embryos (IZEs) were dissected from camelina seeds of various developmental stages and used to induce adventitious shoot formation.

To this end, IZEs or parts thereof were cultivated under various conditions. On nutrient media containing either indole-3-acetic acid (IAA) or 6benzylaminopurine (BAP), leaf-like structures were formed at the surface of hypocotyls. Intriguingly, these structures emerged closer towards the root in the presence of BAP as compared to IAA. This response was the most intense when IZEs of 1.2 to $1.5 \mathrm{~mm}$ in length were cultivated as a whole rather than being divided in stem segments and cotyledons. Over time, the leaf-like structures converted into shoots which themselves gave rise to plantlets upon further cultivation. Current experiments are being conducted to determine the cellular origin of the shoots by histological examination. The information gained from this analysis will be essential for the implementation of the new regeneration system for genetic engineering approaches which are expected to substantially contribute to genetic improvements of camelina. 


\title{
Repeating elements of the hemp genome (Cannabis sativa $\mathbf{L}$. )
}

\author{
Romanov D.V. \\ All-Russia Research Institute of Agricultural Biotechnology, Laboratory of Applied Genomics and Crop \\ Breeding, Kurchatov Genomic Center-ARRIAB, Moscow, Russia \\ email: akabos1987@gmail.com
}

Hemp (Cannabis sativa L.) is an important agricultural plant. All aerial parts of the plant have healing effects. It is used in the treatment of burns, cardiovascular and bronchopulmonary diseases, anemia, fragility of bones, diathesis and diseases of the digestive system. In addition, $C$. sativa is successfully used as a technical culture, as well as in cosmetology and cooking (Russo, 2007). C. sativa is a dioecious plant with XX / $\mathrm{XY}$-sex determination system; there are also monoecious varieties with a female karyotype (XX) (Divashuk et al., 2014). At the same time, dioecious $C$. sativa have some difficulties on the process of its cultivation. Male and female plants ripen at different times, which is why it is necessary to carry out manual weeding, which significantly affects the cost of the product (Faux et al., 2014). Studying the mechanisms of sex determination in the future will make it possible to influence the percentage of males and females in the population. Developing of cytogenetic markers for the identification of the sex chromosomes of $C$. sativa is an important step for their further study. To solve this problem, we analyzed two genome-wide assemblies of cannabis plant (cs10 and cb2) from the NCBI website (www.ncbi.nlm.nih.gov). High-copy sequences of the cannabis plant genome were identified on individual chromosomes and on the entire genomes by using the pyTanFinder program (Kirov et al., 2018), followed by MegaBLAST analysis (www.ncbi.nlm.nih.gov). As the result, we found 46 satellite repeats of $C$. sativa, one of which showed homology to the known subtelomeric repeat (Divashuk et al., 2014). These repeats will be further used for FISH localization on the $C$. sativa chromosomes. Acknowledgments: This work was supported by a grant from the Russian Science Foundation (grant No. 20-76-00036). 


\title{
Development of DNA markers for the selection of spring barley varieties that are resistant to spot blotch
}

\author{
Rozanova I.V.1,2*, Lashina N.M. ${ }^{3}$, Efimov V.M. ${ }^{2}$, Afanasenko O.S. ${ }^{3}$, \\ Khlestkina E.K. ${ }^{1,2}$ \\ ${ }^{1}$ N.I. Vavilov All-Russian Research Institute of Plant Genetic Resources (VIR), St. Petersburg, Russia \\ ${ }^{2}$ Institute of Cytology and Genetics, SB RAS, Novosibirsk, Russia \\ ${ }^{3}$ All-Russian Research Institute for Plant Protection, St. Petersburg, Russia \\ * email: i.rozanova@vir.nw.ru
}

Spot blotch, caused by Cochliobolus sativus, is the one of the most widespread and harmful diseases in barley. The identification of genetic loci associated with resistance to $C$. sativus is the important task for future marker-assisted selection. The goal of the current study was to identify loci conferring seedling resistance to different pathotypes of $C$. sativus in the Siberian spring barley core collection. The collection included 94 spring barley cultivars and lines was created. All of them were phenotyped at the seedling stage with three $C$. sativus isolates $(\mathrm{O} 2.18, \mathrm{Kr} 2$ and $\mathrm{Ch} 3)$. About $40 \%$ genotypes were resistant to spot blotch. A total of 94 genotypes were analyzed with the barley $50 \mathrm{~K}$ Illumina Infinium iSELECT assay. 27,319 SNPs from total 44,040 SNPs passed filtering threshold and were used for association mapping. Several statistical models were used (GLM, GLM+Q, GLM+PCA, MLM) and they allowed to reveal four genome loci (on chromosome 1H (50-61.2 cM), 2H (68.7-69.68 cM), 3H (18.72-26.18 cM), 7H (7.52$15.44 \mathrm{cM})$ ). Only one locus on chromosome $3 \mathrm{H}$ were revealed using MLM analysis. In any way, further, 12 SNPs from all revealed regions were converted to KASP-markers and validated on independent sample that consist of 11 high resistant and 11 high susceptible varieties. According to obtained data, 5 markers located on chromosome $3 \mathrm{H}$ (18.72-26.18 cM) were determined to possess good accuracy. The data were assessed using PASS, Tassel 5, R and SNP-viewer. Information of SNPs related can be used further for development of DNA-markers convenient for diagnostics of resistanceassociated alleles in barley breeding programs. 


\title{
The pathotype structure of the causative agent Puccinia sp. tritici in Kazakhstan
}

\author{
Rsaliyev A.S., Baygutov M.Zh., Maulenbay A.D. \\ Research Institute for Biological Safety Problems, Gvardeisky, Korday District, Zhambyl Region, \\ Kazakhstan \\ *email: aralbek@mail.ru
}

The wheat yellow rust (causative agent - obligate fungus Puccinia striiformis $\mathrm{f}$. sp. tritici) occurs practically every year in Kazakhstan and other Central Asian countries. In 2018 and 2019 year, to determine the development of wheat yellow rust, as well as to collect samples of the pathogen populations the main grain-producing regions of Kazakhstan surveyed. Surveying areas and collecting samples of the pathogen population had held as a part of the route of the expedition, as well as individually. In 2018 and 2019, yellow rust has been observed in the southern and southeastern regions of the Kazakhstan, where mainly winter wheat cultivars cultivated. The development of the pathogen in these regions varied from moderate to severe. The disease developed severely on industrial crops in certain areas of the Almaty, Zhambyl and Turkestan regions, while the damage degree of the disease was in the range of 60-70\%.

The pathotypes of $P$. striiformis $\mathrm{f}$. sp. tritici were identified using International and European sets of differential cultivars in 2018 and 2019. In the analysis of 101 single pustule isolates of $P$. striiformis f. sp. tritici in the Kazakhstan regions, 21 pathotypes of the fungus were identified, which unevenly distributed between populations. In the south and southeast of Kazakhstan in 2018-2019, the predominant pathotypes of the pathogen were 66E35, 39E158, 79E186 and 79E104. The most dangerous pathotypes in Kazakhstan are 39E158, 79E27, 79E43, 79E143, 79E155, 79E186 and 111E158 with virulence of $60.0-73.3 \%$ to differential cultivars of the yellow rust. Among them, pathotypes 39E158, 79E143, and 111E158 were found in early studies and formed the basis of the synthetic population of the yellow rust when determining the resistance of wheat cultivars against an infectious background. 


\title{
The mechanism of the additive action of bacterial compositions Bacillus spp. in the defense response of common wheat against greenbug aphid Schizaphis graminum
}

\author{
Rumyantsev S.D., Alekseev V.Y., Veselova S.V., Cherepanova E.A., \\ Burkhanova G.F., Maksimov I.V. \\ Institute of Biochemistry and Genetics of the UFRC of the RAS, Ufa, Russia \\ * email: rumyantsev-serg@mail.ru
}

Biocontrol agents based on plant-growth promoting bacteria (PGPB) can become an effective and environmentally safe means of plant protection agents against pests. It is possible to enhance the effect of biocontrol agent by compiling bacterial compositions. However, in the world scientific literature, there is practically no information about the effect of the combined action of endophytic bacterial strains on the plant defense systems against pests. Bacterial metabolites are the active origin of any biocontrol product. Our work was aimed at studying the molecular and biochemical mechanisms of action of various combinations of bacterial metabolites of Bacillus spp. on the defense system of wheat plants during the colonization of the greenbug aphid Schizaphis graminum. In our work, we studied 3 bacterial strains that synthesize different groups of metabolites. Thus, the strains of B. subtilis 26D and B. subtilis 11BM produce lipopeptides - surfactin and iturin respectively. The $B$. thuringiensis strain B-5351 synthesizes Cry proteins. The insecticidal activity of the mixture $B$. thuringiensis B-5351+B. subtilis 26D was higher than that of individual strains. All three bacterial mixtures $B$. thuringiensis $\mathrm{B}-5351+B$. subtilis 26D, B. subtilis 26D+B. subtilis 11BM, B. thuringiensis B-5351+B. subtilis $11 \mathrm{BM}$ increased the growth-promoting effect compared to the action of individual strains. All strains and their compositions had an indirect effect on aphid mortality and the formation of induced systemic resistance of wheat plants against $S$. graminum, but the mixture $B$. thuringiensis $\mathrm{B}-5351+B$. subtilis $26 \mathrm{D}$ had the greatest effect. When plants were treated with this mixture, aphid propagation was the lowest, and the accumulation of hydrogen peroxide and the induction of $P R$-genes (from pathogenesis related) expression were the highest.

Acknowledgements: This work was supported by the RFBR in the framework of the research project No. 20-316-90021. 


\section{Identification and analysis of CEP genes expression in Solanum tuberosum}

Rutkovskaya E.A.*, Gancheva M.S., Dodueva I.E., Lutova L.A.

Saint-Petersburg State University, St. Petersburg, Russia

*email: rutkovskaya-ea@yandex.ru

Potatoes are one of the most widespread crops in the world. The nitrogen content in the medium affects the development of potato tubers. The development of various parts of the plant is associated with peptides of the CEP group. It is known that in A. thaliana CEPs are responsible for the expression of nitrate transporters depending on the nitrogen concentration in the medium. In $S$. tuberosum, these genes have not been previously discovered. We identified 5 potato genes: StCEP 1, StCEP 3.1, StCEP 3.2, StCEP14, and StCEP15. Homologues of these peptides are AtCEP1, AtCEP3, AtCEP14, and AtCEP 15. Based on the expression data, the following genes were analyzed: StCEP 3.2, StCEP 14 and StCEP15. These genes are highly expressed in potato roots, which may indicate the effect of this peptide on potato tuberization and development of its root system. It is known that CEP peptides, interacting with their receptors (CEPR), activate CEPD peptides, which regulate the expression of nitrate transporters. As a result, we also identified the CEPDL1, CEPDL2, and CEPDL3 genes expressed in potato leaves, as well as receptor genes.

Acknowledgements: This work was supported by a grant RFBR 19-016-00177. 


\section{Comparative assessment of sugar accumulation in commercial potato cultivars (Solanum tuberosum $\mathrm{L}$.) for genome editing}

Saboiev I. ${ }^{1 *}$, Ibragimova S. ${ }^{1}$, Egorova A. ${ }^{1}$, Salina E. ${ }^{1}$, Kochetov A. ${ }^{1,2}$

${ }^{1}$ Kurchatov Genomic Center of the Institute of Cytology and Genetics, SB RAS, Novosibirsk, Russia

${ }^{2}$ Novosibirsk State University, Novosibirsk, Russia

*email: Saboiev@bionet.nsc.ru

Potato (Solanum tuberosum L.) being a major food crop has the potential to feed the rising world population. Because potatoes harvested only once a year, it is necessary to cold store the tubers to ensure a year-round supply of high-quality potatoes for processing. Potato tubers, during processing have accumulated both reducing sugars (glucose and fructose) and sucrose when subjected to chilling temperatures phenomenon known as cold sweetening. Degree of sugar accumulation is a cultivar dependent factor. Sugar content of three potato cultivars was measure at harvest and after storage. Samples (tubers) of three potato cultivars Nikulinsky, Symphony and Nevski were dried properly and stored at room temperature and in laboratory controlled chambers $\left(4,8,12^{\circ} \mathrm{C}\right)$. The determination of the content of reducing sugars was carried out by the anthrone method. The maximum accumulation of reducing sugars was observe in all three-potato varieties stored at $4{ }^{\circ} \mathrm{C}$. The high amount of glucose was observed in the Nikulinsky cultivar (7.20 mg / fresh weight), slightly less in the cv. Symphony $(6,200)$ and Nevski $(5.727)$. The same tendency was observe in all cultivars in terms of fructose content. All cultivars had a low content of reducing sugars at room temperature. Activities of numerous enzymes involved in certain biochemical reactions in potato tubers during storage closely linked to cold induced sweetening. During low temperature storage of tubers, starch breaks down while sucrose formed by UDP-glucose pyrophosphorylase and sucrose-phosphate synthase. Sucrose is then subsequently hydrolyzed to reducing sugars by soluble acid invertase enzyme (EC 3.2.1.26), a key enzyme involved in the hydrolysis of sucrose to glucose and fructose. As a preliminary study, Potato acid invertase (Painl) expression patterns in the tubers of three cultivars were analyze. In all cultivars, the overall expression level of Painl was fond to be considerably higher after storage at low temperature as compared to the freshly harvested tubers. Cultivars Nikulinsky and Symphony has much Painl activity when tubers storage at temperature $4{ }^{\circ} \mathrm{C}$. Two commercial cultivars Nikulinsky and Symphony with high level of reducing sugars and Painl activity was selected as potential traits donors for genome editing.

Acknowledgments: The study is supported by the Kurchatov Genomic Centre of the Institute of Cytology and Genetics, SB RAS (075-15-2019-1662). 


\title{
$C L E$ genes regulating symbiotic nodule development in Pisum sativum
}

\author{
Sadikova D.S.*, Lebedeva M.A., Lutova L.A. \\ Saint Petersburg State University, St. Petersburg, Russia \\ *email: darinasadikova@yandex.ru
}

Legumes are able to enter into symbiosis with nitrogen-fixing bacteria rhizobia to build the root nodules. Symbiotic nodules provide transfer of nitrogen from rhizobia, necessary to support plant growth. This ability makes legumes key species for natural and agricultural ecosystems and allows to reduce the application of nitrogen-containing fertilizers. In different model legumes, supernodulating mutants have been described that form excessive number of symbiotic nodules even at a high nitrogen content in the soil. These mutants appeared to be defective in genes encoding CLV1-like kinase that acts in the shoot and systemically, via long-distance regulation, inhibits the initiation of symbiotic nodules on the root, thereby limiting the number of developing nodules. The ligands of CLV1-like kinases are mobile CLE peptides that are produced in the root in response to rhizobial inoculation and moves to the shoot to induce AON. In addition, nitrate-induced CLE genes have been identified in model legumes, which inhibited nodulation when overexpressed. In our work we analyzed four homologues of $C L E$ genes in Pisum sativum, which are closely related to nodulation-suppressing CLE in other legumes. The effect of nitrate on the expression of these $C L E$ genes was evaluated. Expression analysis of these four CLE genes at different stages of nodule development in $P$. sativum showed that these genes upregulated in during nodulation. We designed overexpression constructs for PsCLE12 and PsCLE13 genes and obtained composite plants with transgenic roots overexpressing these genes. Our preliminary data show that overexpression of nodulation-specific PsCLE12 gene did not suppress nodulation on transgenic roots, whereas PSCLE13 overexpression decreased nodule number on transgenic roots. Therefore, these two close homologues might have diverse function in nodulation, and we are going to study the mechanisms of their action in pea nodule development.

Acknowledgements: This project was supported by the Ministry of Science and Higher Education of the Russian Federation (agreement No. 075-15-2020-922) on providing a grant for the creation and development of a World-class Scientific Center "Agrotechnologies for the Future". 


\section{Features of crossing and setting of hybrid seeds in hybrid cotton plants with replacement of substitution chromosomes}

Sanamyan M.F.*, Bobokhujaev Sh.U.

Cotton Genetics Laboratory, National University of Uzbekistan, Tashkent, Uzbekistan

* email: sanam_marina@rambler.ru

It is known that cotton of the species $G$. barbadense L. is characterized by such quality and fiber length, which significantly exceed all known varieties of the widely cultivated species G. hirsutum L. The use of aneuploid lines allows the creation of chromosomesubstituted lines with foreign chromosomes, in which the \% of fiber is significantly improved; reduced microneir and increased fiber strength. Analysis of $\mathrm{F}_{1}$ hybrids obtained from crosses of monosomal lines G. hirsutum (Mo) with the line Pima 3-79 of the species $G$. barbadense L. showed that the crossing of two monosome lines on chromosome 2 with the line Pima 3-79 differed significantly (from 33,33 up to 66,67\%); 13 monosome lines on chromosome 4 - strongly (from 12,50 to 100,00\%); 5 monosomelines on chromosome 6 - significantly (from 26,32 to 60,00\%), while the crossability of the monosomal line on chromosome 18 was characterized by a strong decrease (up to 16,66\%), and the monotelodysome line on chromosome 11 had the highest value $(100 \%)$, which was explained by the specificity of the aneuploid lines. Significant differences in the setting of hybrid $\mathrm{F}_{1}$ seeds in the studied variants of crosses (from 16,00 to $52,82 \%$ ) were also due to the specificity of monosomal lines. Crossing of monosomal lines with the original $F_{1}$ hybrids (MoxPima 3-79) showed a general decrease in $\mathrm{F}_{1} \mathrm{BC}_{1}$ hybrids in all variants, with the exception of one $\mathrm{F}_{1} \mathrm{BC}_{1}$ (Mo75xF 1 (Mo75xPima3-79)), which showed an increase in crossbreeding (up to $60.00 \%$ ) in comparison with the original hybrid $\mathrm{F}_{1}(33,33 \%)$. A general decrease in the setting of hybrid seeds $\mathrm{F}_{1} \mathrm{BC}_{1}$ was revealed in comparison with the original $\mathrm{F} 1$ hybrids, with the exception of two variants of crosses: $\mathrm{F}_{1} \mathrm{BC}_{1}\left(\mathrm{Mo67}_{\mathrm{x}} \mathrm{F}_{1}(\mathrm{Mo67xPima3}-79)\right)$ and $\mathrm{F}_{1} \mathrm{BC}_{1}\left(\mathrm{Mo}_{27} \mathrm{xF}_{1}(\mathrm{Mo} 27 \mathrm{xPima3}-79)\right)$, in which an increase in the setting of hybrid seeds was observed (up to 30,43 \pm 9,59 and 53,33 $\pm 7,44 \%$ respectively). In $\mathrm{F}_{1} \mathrm{BC}_{2}$ hybrids, an increase in crossability was found only in two variants of crosses (with Mo75, Mo27) in comparison with the $\mathrm{F}_{1}$ and $\mathrm{F}_{1} \mathrm{BC}_{1}$ hybrids. Thus, the first factor constraining the development of new chromosome-substituted cotton lines is the low cross rate of parental forms, due to the lack of individual chromosomes or their arms in both parental forms, as well as the formation of a small number of fruit elements and the need to combine flowering periods in them. The second limiting factor is the low setting of hybrid seeds in successive backcross generations due to the reduced setting of seeds in the original aneuploid cotton plants, as well as the existence of hidden consequences of interspecific hybridization. 


\section{Generation of haploidy inducers for Cas endonuclease-mediated mutagenesis in barley}

Satpathy P.*, Mirzakhmedov M., Chamas S., Büchner H., Daghma D.E.S., Kumlehn J. Leibniz Institute of Plant Genetics and Crop Plant Research (IPK) Gatersleben, Germany

* email: satpathy@ipk-gatersleben.de

The production and utilization of doubled haploid (DH) lines is one of the most effective biotechnological measures in modern plant breeding. Each DH line is a unique result of meiotic recombination and yet is itself entirely true-breeding (i.e. homozygous across the entire genome). One way to produce DH lines is to employ haploidy-inducing lines as pollinators. To some extent, the progeny of such crosses include haploid plants that carry only the genome derived from egg cells of the pollinated mother plant. In maize, the capability of inducing haploid progeny proved to be largely due to loss-of-function of the sperm cell-specific PHOSPHOLIPASE A 1 (PLAl) gene. With the aim to produce haploidy-inducing lines for barley, we identified the barley PLAl orthologue that was then subjected to site-directed mutagenesis using Cas endonuclease technology. Among the generated transgenic plants carrying cas 9 and $H v P L A l$-specific guide RNA expression units, nine proved mutated in their target motifs. Selfing of these mutants resulted in haploid progeny with an efficiency of about 5\%. The haploidy-inducing capacity of these mutants was then confirmed and quantified by employing them to pollinate wild-type barley, which resulted in a proportion of 5.8\% haploid progeny. Using such plal knockout lines, we are further about to establish a method of targeted mutagenesis that may be applicable to any barley genotypes of choice. This concept involves the delivery of Cas 9 and target gene-specific guide RNA from sperm cells of cas9/guide RNA-transgenic haploidy inducer lines to the zygote via fertilization, so that the wild-type genomes derived from the maternal parents become accessible to sitedirected mutagenesis, whereas the paternal, transgene-carrying genome is lost during early embryogenesis. Colchicine-induced genome duplication may then give rise to doubled haploid, transgene-free plants, whose exclusively maternally derived genetic makeup is carrying homozygous mutations in their target gene-of-interest. 


\section{Microevolution events in Allioideae (Amaryllidaceae) plastomes}

Scobeyeva V.A. ${ }^{1,2}$, Artyushin I.V. ${ }^{1}$, Krinitsina A.A. ${ }^{1}$, Nikitin P.A. ${ }^{1 *}$, Antipin M.I. ${ }^{1}$, Kuptsov S.V. ${ }^{1}$, Belenikin M.S. ${ }^{2}$, Omelchenko D.O. ${ }^{3}$, Logacheva M.D. ${ }^{4}$, Konorov E.A. ${ }^{5}$, Samoilov A.E. ${ }^{6}$, Speranskaya A.S. ${ }^{1,6}$

${ }^{1}$ Lomonosov Moscow State University, Moscow, Russia

${ }^{2}$ Moscow Institute of Physics and Technology, Moscow, Russia

${ }^{3}$ Institute for Information Transmission Problems (RAS), Moscow, Russia

${ }^{4}$ Center of Life Sciences, Skolkovo Institute of Science and Technology, Moscow, Russia

${ }^{5}$ Vavilov Institute of General Genetics, Russian Academy of Sciences, Moscow, Russia

${ }^{6}$ Central Research Institute of Epidemiology (CRIE), Moscow, Russia

*email:niki4pingvi@mail.ru

Amaryllidaceae is a large family with more than 1600 species, belonging to 75 genera. The largest genus - Allium - is vast, comprising about a thousand species. Allium species (as well as other members of the Amaryllidaceae) are widespread and diversified, they are adapted to a wide range of habitats from shady forests to open habitats like meadows, steppes and deserts. The genes present in chloroplast genomes (plastomes) play fundamental roles for the photosynthetic plants [1]. Plastome traits could thus be associated with geophysical abiotic characteristics of habitats. Most chloroplast genes are highly conserved and are used as phylogenetic markers for many families of vascular plants. Nevertheless some studies revealed signatures of positive selection in chloroplast genes of many plant families including Amaryllidaceae. In this work we provide analysis of Allioideae subfamily plastid genomes microevolutionary events. First of all, we prepared primary cpDNA alignment of 38 species of Allium genera (including all the three evolutionary lines [2]) and 11 other species of Amaryllidaceae family as an outgroup, both provided by our group and NCBI GenBank. Then we constructed a maximum likelihood phylogenetic tree with IQ-Tree2. With this data we got some information of relative tree length in alignment blocks and $\mathrm{dN} / \mathrm{dS}$ rate for evaluating the balance between neutral mutations and positive/negative natural selection. Sites under selection were found with aBSREL (adaptive Branch-Site Random Effects Likelihood); FUBAR (Fast Unconstrained Bayesian AppRoximation) и MEME (Mixed Effects Model of Evolution) as well. We found that infA, ccsA, rps 2 and rps 16 genes have lost their functionality multiple times in different species (regularly evolutionary events), while the pseudogenization of other genes was stochastic events. We found that the "normal" or "pseudo" state of rps2, infA, rps 16 and $\operatorname{css} A$ genes correlates well with the evolutionary line of genus the species belongs to. Independent methods revealed some genes being under positive selection, such as housekeeping genes (accD, ccsA, rpll6, rpl20, rps16, rpoA, rрoB, matK). The most interestingly, the part of photosynthesisinvolved genes were also found under positive selection (various $n d h$ genes, $p s b M$ and $r b c L)$ as well as genes of unknown function ( $y c f 1, y c f 2)$. Taking into account known mechanisms of coping with excessive light by cyclic electron transport, we can hypothesize that adaptive evolution in genes, coding subunits of NADH-plastoquinone oxidoreductase could be driven by abiotic factors like temperature, light intensity or UV radiation [3].

References

1 Daniell H., Lin C.-S., Yu M., Chang W.-J. Gen. Biol. 2016;17:134.

2 Friesen N., Fritsch R.M., Blattner F.R. Aliso: Journal Systematic Evolutionary Botany. 2006;22:372-395.

3 Martín M., Sabater B. Plant Physiol. Biochemistry. 2010;48:636-645. 


\title{
The selection of efficient sgRNAs for CRISPR-Cas9 genome editing of potato (Solanum tuberosum $\mathbf{L}$.) aimed to obtain the cultivars with low-amylose starch properties
}

\author{
Sergeeva E.M. ${ }^{1 *}$, Larichev K.T. ${ }^{2}$, Bragina M.K. ${ }^{1}$, Salina E.A. ${ }^{1}$, Kochetov A.V. ${ }^{1}$ \\ ${ }^{1}$ Kurchatov Genomic Center of the Institute of Cytology and Genetics, SB RAS, Novosibirsk, Russia \\ ${ }^{2}$ Novosibirsk State University, Novosibirsk, Russia \\ * email: sergeeva@bionet.nsc.ru
}

Potato (Solanum tuberosum L.) is an important starch producing agricultural plant. Starch is the main storage carbohydrate widely used for industrial and nutritional needs. The starch functional properties are mainly defined by the ratio of two polysaccharides: amylose and amylopectin. The aim of the study is development of Russian potato varieties with low- or no-amylose starch properties using the CRISPR-Cas9 genome editing. The GBSS1 gene is known to be responsible for amylose biosynthesis in potato tubers. The cultivars of choice for editing were popular varieties Nevskiy and Udacha which have good in vitro regeneration ability. For precise GBSS1 gene targeting we made single guide RNA design using the Illumina genomic sequencing data for Nevskiy and Udacha (obtained on NextSeq550 at the ICG SB RAS Core Genome Facility). The obtained reads were aligned to the GBSS1 from PGSC reference genomic sequence. The resulting GBSS1 consensus gene sequences were analyzed with CRISPOR, CRISPRdirect, CRISPR-P programmes to pick the candidate sgRNAs. From 109 total output oligos six were selected based on criteria of predicted specificity and secondary structure. The six selected sgRNAs are targeted to GBSS1 exon 1 and exon 10 sequences. At the next step, 6 sgRNAs were synthesized in vitro with the aid of Precision gRNA Synthesis Kit (Invitrogen) and cloning of the corresponding oligos to pUC57-sgRNA expression vector. The obtained sgRNAs were in vitro pre-validated as part of Cas9 ribonucleoprotein (RNP) complex to cleave the PCR-produced GBSS1 sequences of Nevskiy and Udacha. The next step the efficient constructs will be used for DNA-free biolistic transformation of potato protoplasts.

Acknowledgements: This work was done within the framework of State Assignment Kurchatov Genomic Center of the Institute of Cytology and Genetics, SB RAS (075-152019-1662). 


\title{
Detection of the binding the stress HliA protein Synechocystis sp. with pigments
}

\author{
Sharapova L.S.*, Yurina N.P. \\ Bach Institute of Biochemistry, Federal Research Center "Fundamentals of Biotechnology" of the Russian \\ Academy of Sciences, Moscow, Russia \\ * email: sharapova0902@mail.ru
}

The high-light-inducible (Hli) proteins of cyanobacteria is considered as the evolutionary precursors of chlorophyll a/b-binding proteins of plants and algae. It has been shown that Hlips are essential for cell survival under intense light conditions, are involved in the regulation of chlorophyll biosynthesis, transport and binding of free chlorophyll molecules, quenching of singlet oxygen, assembly and repair of photosystem II, and non-photochemical dissipation of absorbed light energy. However, the full picture of the functioning and localization of Hli proteins is not fully understood. To protect cells from excessive light, an important process is the binding of phototoxic free chlorophyll molecules that cause photodestruction and oxidative stress. Hli proteins can serve as such key binding agents for these molecules. Four Hli proteins (HliA, B, C, and D) were found in cyanobacteria Synechocystis sp. PCC 6803. Previously, these proteins were isolated as part of small complexes with other photosystem proteins. In this paper, for the first time, the isolation and characterization of the pure HliA protein Synechocystis sp. A recombinant plasmid containing the HliA gene with $6 \mathrm{His}$ at the Cterminus (HliA-6His) of the protein was obtained. The pure recombinant HliA protein of Synechocystis sp was isolated by Ni-chelate chromatography. The HliA protein was reconstituted with chlorophyll a and carotenoids. Using circular dichroism spectroscopy, it was shown that chlorophyll a and carotenoids interact in vitro with the HliA protein. The binding of pigments to the HliA protein indicates the protective role of this protein. The HliA protein was found to be important for the oxygen uptake reaction in photosystem I with an artificial donor and acceptor. The necessity of HliA for optimal photochemical activity of the photosystem I complex is shown. The results are important for understanding photoprotection processes in both cyanobacteria and algae and higher plants.

Acknowledgements: This work was partially supported by the Russian Foundation for Basic Research (Grant No. 19-04-00798). 


\title{
Genome-wide association study in wheat to identify resistance against Pratylenchus thornei and Heterodera avenae
}

\author{
Sharma Shailendra ${ }^{1 *}$, Sharma Shiveta ${ }^{1}$, Kumar D. ${ }^{1,2}$, Singh V.K. ${ }^{1}$, Pundir S. ${ }^{1,2}$, \\ Chaturvedi D. ${ }^{1}$ \\ ${ }^{1}$ Department of Genetics and Plant Breeding, Chaudhary Charan Singh University, Uttar Pradesh, India \\ ${ }^{2}$ Department of Botany, Chaudhary Charan Singh University, Uttar Pradesh, India \\ *email:Shgjus6@gmail.com
}

\begin{abstract}
Bread wheat (Triticum aestivum L.), is one of the most important staple food crops of the world. Production of wheat can be limited by various biotic factors, including plantparasitic nematodes (PPNs) which are also known as the 'hidden enemy' of crops as they pose a serious threat to global food security. PPNs cause losses of $\sim 12.6 \%$ among different crop plants, representing an annual monetary loss of 216 billion US\$. The most damaging PPNs are the root-knot nematodes (RKNs), cereal cyst nematodes (CCNs) and root lesion nematodes (RLNs). Identification of the novel resistance sources is of high importance for applied breeding. In the present study, 143 and 323 wheat genotypes were screened against RLN (Pratylenchus thornei) and CCN (Heterodera avenae) respectively. GWAS was conducted to find out the significant marker-trait associations (MTAs) underlying $P$. thornei resistance. A total of 25 MTAs were obtained which were further explored to find out putative candidate genes. Ten highly resistant and 10 highly susceptible genotypes were selected from these 143 wheat genotypes and further validated to confirm resistance for $P$. thornei. GWAS analysis to find MTAs for $H$. avenae resistance in 323 wheat genotypes is underway.
\end{abstract}




\title{
Structural analysis of the candidate gene that controls awn length in common wheat Triticum aestivum $\mathrm{L}$.
}

\author{
Shcherban A.B.*, Kuvaeva D.D., Salina E.A. \\ Kurchatov Genomic Center of the Institute of Cytology and Genetics, SB RAS, Novosibirsk, Russia \\ *email: atos@bionet.nsc.ru
}

The trait of awness is associated with a number of important, selectively significant plant properties, such as drought resistance, the technological quality of the grain mass during its processing, etc. The main manifestations of this trait are controlled by the B1 locus on the long arm of chromosome 5A. As a result of the previously performed fine mapping, two candidate genes for B1 have been identified, one of which belongs to the vast and poorly understood family of genes encoding transcription factors with the $\mathrm{C} 2 \mathrm{H} 2$ zinc finger domain. We carried out a comparative analysis of the primary structure of this gene in a number of domestic awned and awnless varieties of common wheat T. aestivum L. Along with the absence of polymorphism in the coding region of this gene, we identified 6 SNPs in the promoter region, which, according to our and other data, have a high degree of association with the trait of awness. Based on the identified haplotypes corresponding to the dominant and recessive alleles of the putative B1 gene, we constructed markers for these alleles, which were successfully tested on the material of various varieties of common wheat, $T$. spelta $\mathrm{L}$. wheat lines, as well as on F2/F3 hybrids from crossing between awned and awnless forms of T. aestivum. In the latter case, the correspondence of the established genotypes for B1 to Mendelian segregation by awness was shown.

Acknowledgements: The work was supported by RSF grant No. 21-76-30003. 


\title{
Determination of the size of introgressions from Triticum timopheevii Zhuk. in the recombinant lines of bread wheat cultivar Saratovskaya 29 and their association with protein and gluten content in grain
}

\author{
Shchukina L.V.*, Pshenichnikova T.A. \\ Institute of Cytology and Genetics, SB RAS, Novosibirsk, Russia \\ * email: quality@bionet.nsc.ru
}

Gluten and protein content in wheat grain are important economic attributes that determine grain quality and its end use. Molecular markers are now making it possible to elucidate the details of the genetic control of these quantitative traits. Alien and lowcultivated wheat species are the recognized sources of reinforcement of bread wheat germplasm. Previously, we studied the introgression line 821 of Saratovskaya 29 (S29) cultivar for a number of technological characteristics of grain. This line outperformed the parent cultivar in grain gluten content and had a high grain quality. The line 821 was obtained by E.B. Budashkina from crossing S29 and tetraploid species T. timopheevii Zhuk. The size and location of introgressions in 2A, 2B, and 5A chromosomes were determined by microsatellite markers. The inter-varietal substitution line S29 (821 2A) was developed to study the effect of introgression in chromosome $2 \mathrm{~A}$ on gluten and protein content in grain in the absence of the two other introgression. The line S29 (821 2A) demonstrated a higher gluten and protein percentage in grain compared to S29. The correctness of chromosome substitution was monitored using microsatellite markers. The aim of this work was to reduce the size of the introgression from $T$. timopheevii in $2 \mathrm{~A}$ chromosome while maintaining a high content of protein and gluten. For this, two backcrosses of the line S29 (821 2A) to S29 parental cultivar were performed. As was identified using molecular markers, the resulting recombinant lines carry the introgressions of different size on $2 \mathrm{~A}$ chromosome. Seven lines were selected from the offspring for further reproduction and field studies. The report will present the results of their study for protein and gluten content and other technological characteristics of grain. Acknowledgments: This work was carried out within the framework of the budget project No. 0259-2021-0018. 


\title{
The bacterial impact on the transcriptional activity of $D C L 2$ and $D C L 4$ genes in wheat plants infected with Stagonospora nodorum
}

\author{
Shein M.*, Burkhanova G., Maksimov I. \\ Institute of Biochemistry and Genetics - Subdivision of the Ufa Federal Research Centre of the Russian \\ Academy of Sciences, Ufa, Russia \\ * email: mikeshenoda@yandex.ru
}

RNA interference is a unique natural defense mechanism that is supposedly aimed at protecting plants. The key components of plant RNAi are DICER-like proteins (DCL) with RNase activity. The DCL2 and DCL4 genes are of great interest, since their proteins are involved in the development of the plant systemic response upon activation of the RNAi system in response to pathogenic infection. In this study, our aim was to research the effect of endophytic bacteria that stimulate plant growth on the RNAi mechanism and development of disease symptoms at early stage of infection in various wheat genotypes infected with Stagonospora nodorum. Our result indicates that in the susceptible common wheat a gradual increase in the transcriptional activity of DCL2 and $D C L 4$ in infected wheat plants, but in resistance to $S$. nodorum Berk. cultivar's of soft spring wheat it is significantly higher. Treatment of wheat with B. subtilis strain 26D promoted the activation of the accumulation of transcripts of the DCL2 and DCL4 genes in the susceptible wheat cultivar. It is probably indicates a redistribution of plant potential. Was shown that infection of a resistant cultivar with the $S$. nodorum leads to the activation of the pro / antioxidant system of plants, as well as the activation of the expression of several genes responsible for other defense systems. Thus, expression of the DCL2 and DCL4 genes, genes transcripts encoding protective proteins, increased the tolerance of wheat plants are markers of systemic resistance. The ability of endophytic bacteria of the Bacillus subtilis 26D strain to activate the accumulation of transcripts of the studied genes after infection suggests that $D C L$ genes are genes primed plants under the influence of $B$. subtilis 26D bacteria.

Acknowledgements: This work was supported by the RFBR project No. 20-34-90004. 


\title{
Search of genome-wide associations for breeding of spring wheat varieties with high zinc content
}

\author{
Shepelev S.S. ${ }^{1 *}$, Shamanin V.P. ${ }^{1}$, Pototskaya I.V. ${ }^{1}$, Chursin A.S. ${ }^{1}$, Kuzmin O.G. ${ }^{1}$, \\ Morgounov A.I. ${ }^{2}$ \\ ${ }^{1}$ Omsk State Agrarian University, Omsk, Russia \\ ${ }^{2}$ Food and Agriculture Organization of the United Nations, Riyadh, Saudi Arabia \\ *email: ss.shepelev@omgau.org
}

Zinc is a biologically active essential trace element for human life and health, one of the sources of which is cereal grain. The search of loci that control the zinc accumulation in wheat grain with usage of GWAS serves as the basis for development of wheat breeding strategy for functional nutrition. A collection of 150 varieties and lines of spring bread wheat of various origins (varieties from Russia, Kazakhstan, USA, synthetic hexaploids with Aegilops tauschii genome) was used for GWAS. Phenotyping of this collection in 2017-2018 was carried out. Entries were distributed in plot that was area $1.4 \mathrm{~m}^{2}$. Field trials utilized a randomized complete block design with four replicates. The zinc content in grain was determined at the University of Nottingham (UK). Genotyping of entries at the University of Nebraska-Lincoln (United States) was performed using the iSelect90K array. The method FarmCPU was used in MVP R software package for association test of markers. GWAS revealed SNPs associated with high zinc content (MTAs) in A genome - 49 SNPs, B genome - 36 SNPs, D genome - 38 SNPs. In 2017 SNP markers identified: S1D_22099159, S7A_287882406, S5A_478857359, S2B_213037042, S2B_213037036. The most significant association with studied trait was revealed on chromosome 1D with effect $11.2 \mathrm{mg} / \mathrm{kg}$ (marker S1D_22099159). According to vegetation season results in 2018 nine MTAs were detected on chromosomes 4A, 5A, 6B，7B，2D $\left(\mathrm{p}<1 \times 10^{-6}\right):$ S7B_374441352, S2D_35548157, S2D_35548171, S6B_584715980, S6B_584715992, S5A_554563813, S2D_30935042, S2D_646433883, S4A_686579282. Marker S5A_554563813 was identified on chromosome $5 \mathrm{~A}$, which associated with zinc accumulation in grain $(41.0 \mathrm{mg} / \mathrm{kg})$. SNPs associated with high zinc content identified across two years $\left(\mathrm{p}<1 \times 10^{-4}\right)$ : S1D_481791231, S6A_597841993, S6D_451861634, S6D_451861645, S6D_451861651, S6D_451861655,S6A_597692159. Practical interest for breeding are synthetic wheat lines as sources of high zinc content in grain, and genes of D genome from the IWGSC RefSeq v1.0 were annotated as TraesCS1D02G059300, TraesCS1D02G187500, TraesCS2D02G018300, TraesCS3D02G098600, TraesCS5D02G437100, TraesCS6D02G359700. 


\title{
Pan-transcriptomic analysis of Solanum tuberosum NLR genes regulating resistance to Phytophthora infestans
}

\author{
Shmakov N.A. ${ }^{1,2,3 *}$, Kochetov A.V. ${ }^{1,2,3}$, Afonnikov D.A. ${ }^{1,2,3}$, Vasiliev G.V. ${ }^{1}$ \\ ${ }^{1}$ Institute of Cytology and Genetics, SB RAS, Novosibirsk, Russia \\ ${ }^{2}$ Kurchatov Genomic Center of the Institute of Cytology and Genetics, SB RAS, Novosibirsk, Russia \\ ${ }^{3}$ Novosibirsk State University, Novosibirsk, Russia \\ *email: shmakov@bionet.nsc.ru
}

Potato (Solanum tuberosum L.) is, according to FAOSTAT data, the sixth most important crop species in terms of production amounts. Potato yields can suffer from several biogenic and abiogenic factors. One of the most damaging biological factors is Phytophthora infestans, an oomycete pathogen that causes late blight of potato and tomato. A modern strategy of pathogen defense is identification of genetic markers of plant resistance to specific pathogen, which then can be used to create new strains, resistant to pathogen attacks. An important role in plant resistance to pathogens is played by proteins of NBS-LRR family, which identify pathogens and trigger immune response of the plant. In order to identify genetic markers of potato resistance to P. infestans, transcriptomes of four potato strains contrasting in susceptibility to the pathogen, and Solanum stoloniferum, a closely related wild member of Solanum genus, that is believed to be highly resistant to $P$. infestans, were studied. RNA-seq libraries of the plants were sequenced, and de novo transcriptome assembly was performed. After transcriptomes filtering and annotation, NBS-LRR domains were identified in the predicted protein sequences. Expression profiles of NBS-LRR genes were compared, and differential expression was observed for some of the NBS-LRR genes. Presence/absence variations and sequence variations between potato strains were observed for NBS-LRR genes. In addition, de novo assembled transcripts with no significant homology to genome were found, among which NBS-LRR genes were present. Thus, novel resistance genes of potato were identified. Finally, some of the known genes-markers of late blight resistance were identified in the assembled transcriptomes. Differences in sequences and expression profiles of marker genes were observed between potato strains.

Acknowledgements: This work was supported by the Kurchatov Genomic Center of the Institute of Cytology and Genetics, SB RAS (agreement No. 075-15-2019-1662). 


\title{
Ant13 encodes the WD40 regulatory factor controlling anthocyanin and proanthocyanidin synthesis in barley (Hordeum vulgare $\mathbf{L}$.)
}

\author{
Shoeva O. ${ }^{1,2 *}$, Kukoeva T. ${ }^{1,2}$, Zakhrabekova S. $^{3}$, Hansson M. ${ }^{3}$ \\ ${ }^{1}$ Institute of Cytology and Genetics, SB RAS, Novosibirsk, Russia \\ ${ }^{2}$ Kurchatov Genomic Center of the Institute of Cytology and Genetics, SB RAS, Novosibirsk, Russia \\ ${ }^{3}$ Lund University, Lund, Sweden \\ *email: olesya_ter@bionet.nsc.ru
}

Proanthocyanidins (PAs) are polymeric flavonoid compounds that accumulate in the seed coat of barley grains. Despite the important role of PAs in seed dormancy, their absence in barley grain is a valuable agricultural trait. In particular, their ability to bind proteins negatively affect nutrient uptake and weight gain in poultry and cause colloidal haze in beer. Therefore, identification of recessive alleles of the genes that control synthesis of PAs in barley with the least effect on growth and development is an important task in breeding PA-free barley cultivars. Analyses of PAs in grains of two hundred varieties from the GenAgro collection (ICG SB RAS, Novosibirsk) did not reveal any PA-free cultivars. Hence, artificially induced barley mutants with lesion in anthocyanin and/or proanthocyanidin biosynthesis can be considered as the only source of recessive alleles of the PAs synthesis genes. Such collection, consisting of 766 individual mutants, is maintained at NordGen (Alnarp, Sweden). In the current study, molecular functions of the Ant13 locus and its effect on plant growth and development were determined. Phenotyping of the mutants for Ant 13 locus confirmed that they do not contain PAs in the grains and anthocyanins in leaf sheaths. Further, they were characterized by similar germination rates compared to the parental cultivar Foma but had decreased rate of root and shoot growth. Co-localization of the Ant13 locus, mapped to chromosome $6 \mathrm{HL}$, with the gene that encodes for the WD40 protein suggested this gene as a candidate for Ant13. The gene was transcriptionally active in seedling roots, seedling shoots, leaves, and developing grains. Sequencing of the WD40 gene in a set of allelic mutants ant13.13, ant13.152, ant13.222, ant13.2010, ant13.2011 revealed single nucleotide nonsense and missense mutations in this gene disrupting the function of the WD40 protein. The data obtained showed that the gene has pleiotropic functions in flavonoid biosynthesis and plant development.

Acknowledgments: The study was partly supported by the Kurchatov Genomic Center of the Institute of Cytology and Genetics, SB RAS, No. 075-15-2019-1662 and the Swedish Institute Visby Programme 25896/2018. 


\title{
Influence of an introgression from Triticum timopheevii into chromosome 5A of bread wheat cultivars Saratovskaya 29 and Diamant 2 on agronomical, physiological and biochemical parameters under contrasting irrigation conditions
}

\author{
Simonov A.V. ${ }^{1 *}$, Smirnova O.G. ${ }^{1}$, Permyakov A.V. ${ }^{2}$, Permyakova M.D. ${ }^{2}$, \\ Osipova S.V. ${ }^{2}$, Pshenichnikova T.A. ${ }^{1}$ \\ ${ }^{1}$ Institute of Cytology and Genetics, SB RAS, Novosibirsk, Russia \\ ${ }^{2}$ Siberian Institute of Plant Physiology and Biochemistry, Irkutsk, Russia \\ *email: sialexander@bionet.nsc.ru
}

The relative species enlarge a variability of bread wheat. From the species Triticum timopheevii, a line 821 inherited an introgression in the subtelomeric region of the long arm of 5A chromosome flanked by the markers Xgwm179 and Xgwm291. It includes the gene for leaf pubescence $H l^{t t}$ determining the formation of long, rare trichomes. Leaf pubescence plays an adaptive role in the response to abiotic stresses by changing the processes of gas exchange. The drought-tolerant cultivar Saratovskaya 29 (S29) carries two pubescence genes that form a dense layer of short trichomes. The non-droughtresistant cultivar Diamant 2 (Dm2) is practically glabrous. The aim of this work was to assess the effect of introgression carrying the gene $H l^{t t}$ on productivity and physiological and biochemical parameters under contrasting irrigation conditions. For this, substitution lines S29(821-5A) and Dm2(821-5A) were created. Under drought and irrigation conditions, the line $S 29(821-5 \mathrm{~A})$ showed a reduced productivity in comparison with the recipient: the number of grains per plant by $17-19 \%$ and the weight of 1000 grains by 15-28\%. The line Dm2(821-5A) retained the yield under irrigation and the weight of 1000 grains increased by $9 \%$. Under drought, this line surpassed the recipient for weight of 1000 grains by 1.5 times. These differences can be explained by the differences in physiological properties. In the line Dm2(821-5A), under both conditions, a decrease in transpiration rate and stomatal conductance was noted, and the efficiency of water use doubled. In S29(821-5A), under both conditions the photosynthetic parameters did not change. Under both conditions, S29(821-5A) showed a decrease of the total activity of the main antioxidant enzymes. Thus, the described introgression is favorable for Dm2, but negatively affects the drought tolerance of S29.

Acknowledgements: The work was carried out within the budget project No. 0259-20210018. 


\section{The variability of organelle genomes in barley}

Siniauskaya M.*, Ermakovich A., Liaudansky A., Davydenko O.

Institute of Genetics and Cytology, NAS, Minsk, Belarus

*email:m.sin@inbox.ru

The complete sequences of the chloroplast and mitochondrial genomes of previously unexplored wild and cultivated barley specimens were obtained by high-throughput sequencing (more than 20 samples). The database of barley organelle DNA polymorphic loci was created. Important SNP located at 3'-, 5'- UTR, promoter regions were defined according map of barley's transcriptome. A bioinformatic search for possible editing sites in the chloroplast genome was carried out. Resulting from NGS SNPs were mapped to predicted editing sites. Most probable SNPs with nonsynonymous amino acid substitutions were tested for the possibility of mRNA editing. A comparative study of cDNA and chloroplast DNA for positions 2634 (matK), 25067 (rpoCl), 49408 (ndhK), 76884 (infA), 111390 (ndhG), 29020 (rpoC2) showed that their nucleotide compositions did not differ for early seedlings stage. The variability of specific chloroplast and mitochondrial DNA regions was studied among 104 barley cultivars and lines (including 20 samples from the collection of IPK Gatersleben Genbank). 12 plasmotypes were distinguished among all studied barley's only for 7 marker regions of organelle genomes (according combained data of NGS and on individual polymorphic loci of organelle DNA). Relatively high level of organelle genomes variability was revealed. It has been shown that certain barley varieties have unique sequences of chloroplast and/or mitochondrial genes. How important this is for the functions of plants remains to be shown in the future.

This study opens up prospects for MAS, taking into account nuclearcytoplasmic interactions for the implementation of the plant genotype. Acknowledgments: The work was financed by GPNI "Biotechnology" 2019-2023 years. Subprogramme 2 "Structural and functional genomics", projects 2.29, 2.1.3. 


\title{
Analysis of the transcriptomic profile of three peach varieties with different ripening periods
}

\author{
Slobodova N.V. ${ }^{1 *}$, Gladysheva-Azgari M.V. ${ }^{1}$, Boulygina E.S. ${ }^{1}$, Tsygankova S.V. ${ }^{1}$, \\ Sharko F.S. ${ }^{1}$, Mitrofanova I.V. ${ }^{2}$ \\ ${ }^{1}$ National Research Center "Kurchatov institute", Moscow, Russia \\ ${ }^{2}$ Nikitsky Botanical Garden - National Scientific Center of the Russian Academy of Sciences (NBG-NSC \\ RAS), Yalta, Russia \\ *email:nv.slobodova@gmail.com
}

For transcriptome analysis, three peach (Prunus persica) varieties from the collection of the Nikitsky Botanical Garden - National Scientific Center of the Russian Academy of Sciences (NBG-NSC RAS) were selected. Selected P. persica varieties ('Sovetskij', 'Loadel', 'Granatovij') have different ripening periods. Fruit samples were collected at three different stages of maturation and fixed in the RNA stabilizer. 23 barcoded RNASeq libraries were obtained, which were sequenced on a NovaSeq 6000 (Illumina, USA). Differential gene expression (DEG) analysis was performed using the DESeq2 software package. Gene Ontology (GO) enrichment analysis for differentially expressing genes was performed using ShinyGO using the Biological Process (BP), Cellular Component (CC), Molecular Function (MF) databases, and the KEGG database. Gene pathway analysis was performed using the R package GAGE based on the KEGG pathway database. A total of 25628 annotated genes were obtained, which is $95 \%$ of the genes presented in the databases. When comparing DEG between three cultivars, the greatest difference in the number of expressed genes was found between the late-maturing 'Sovietskij' variety and the mid-maturing 'Loadel' variety (2655 genes differed in expression). When comparing DEG by stages of maturation, it was found that the greatest differences occur during the transition from the second to the third stage, and the number of genes with reduced expression significantly increases. By the third stage, the expression of genes associated with the organization of organelles, chromosomes, the cell cycle, and processes associated with microtubules generally increases and the expression of genes associated with the biosynthesis of secondary metabolites, transduction of plant hormone signals, and carbon metabolism decreases. 


\section{GWAS between flax accessions and agronomically important phenotypic traits}

Sokolkova A. ${ }^{1}$, Rozhmina T. ${ }^{2}$, Kanapin A. ${ }^{1}$, Samsonova A. ${ }^{1}$, Surkova S. ${ }^{1}$, Bankin M. ${ }^{1}$, Samsonova M. ${ }^{1}$

${ }^{1}$ Peter the Great St. Petersburg Polytechnic University, St. Petersburg, Russia

${ }^{2}$ Federal Research Centre for Bast Fiber Crops, Torzhok, Russia

*email: alyonasok@yandex.ru

Flax is one of the most important crops, both in Russia and in other countries. In modern conditions, fibre flax is considered as a strategic crop in Russia, since it is able to replace raw cotton, which has moved into the category of imported raw materials. Oil flax is used for the production of seeds, which are characterized by valuable nutritional and therapeutic properties. The flax collection created at the Federal Research Centre for Bast Fiber Crops is one of the largest in the world and covers almost all the genetic diversity of the crop. The collection was screened for resistance to Fusarium wilt and highly resistant samples were identified. Here we present the results of GWAS for 306 accessions from this collection. We performed 8X depth genome sequencing for accessions and called 3,416,829 SNPs. Further SNP filtering was implemented with inclusion criteria: minor allele frequency (MAF) more than 3\%, genotype call-rate more than $90 \% .49,621$ SNPs passed all filters and remained for further analysis. Phenotyping of 306 accessions was performed three times at experimental station in Torzhok, Russia: in 2019 and two times in 2020. The measured traits are plant height, length of technical part of the stem, technical part weight, inflorescence length, number of bolls, seeds per plant, 1000 seed weight, the diameter of the stem, the number of internodes, distance between internodes and resistance to Fusarium wilt. The accession fiber quality was estimated by calculating stem slenderness, stem taperingness and ultimate fiber length. GWAS analysis was performed using the mixed linear model (MLM) with Principal component analysis (PCA) axes scores and Q matrix from analysis of population structure used as covariates for all phenotypic data. GWAS analysis identified a large number of genome intervals and potential gene candidates that may affect important agronomic traits.

Acknowledgments: This work is supported by the RSF grant 19-16-00030. 


\title{
The study of the cross-interaction of antibodies with antigens of different types of human papillomaviruses (HPV)
}

\author{
Stolbikov A.S.*, Salyaev R.K., Rekoslavskaya N.I. \\ Siberian institute of plant physiology and biochemistry SB RAS, Irkutsk, Russia \\ * email:valkir5@yandex.com
}

Antigenic proteins of papillomaviruses of high-risk oncogenic types HPV16 L1, HPV18 L1, HPV31 L1, HPV45 L1 as well HPV6 L1 of anogenital types were obtained in the plant expression system on the base of transgenic with these types of tomato fruits using genetic constructs: RB-> p35S->RdRP(2a+2b)->t35S->p35S->HPV16 L1 $(18,31,45,6)$. The amount of antigenoc proteins was calculated upon calibrating line using commercial available antigenic proteins HPV16 L1 and HPV18 L1 after the reaction with monoclonal antibodies raised to these proteins. To rise antibodies, mice were peroral vaccinated 3 times with $500 \mathrm{mg}$ of vaccine material of transgenic tomato fruits with appropriate gene constructs with the interval of one month. After 8 months after last vaccination, mice peripheric blood and spleen were collected to provide analyses of the content of antibodies by ELISA and Western blot hybridization with the comparison of obtained data with results of the reaction of commercial antibodies and antigens. It was shown that all antigenic proteins HPV L1 occured to able for cross-reaction with antibodies of each type, moreover the anogenital type HPV6 L1 cross-reacted with antibodies to types HPV16 L1 $(18,31,45)$. Due to Elispot analisis, it was found that antigenic protein HPV16 L1 was able to induce syntheses of interferon, CD4+ and CD8+ $\mathrm{T}$ lymphocytes in blood serum and splenocytes of mice vaccinated with other types of L1 of papillomaviruses. The analysis of potential linear antigenic determinants of B lymphocytes has been done with the program"BepiPred-2.0: Sequential B-Cell Epitope Predictor". Potential 3-dimesional antigenic determinants of B lymphocytes were searching by the program "DiscoTope 2.0 Server". The program "SYFPEITHI" was used for the determination of antigenic epitops of $\mathrm{T}$ lymphocytes. It was found during this investigation that $\mathrm{T}$ and $\mathrm{B}$ lymphocytes have the common linear determinant for 4 types of papillomavirus proteins L1 16,18,31 and 45. Similar 3-dimensional antigenic determinants were found for B lymphocytes for HPV16 L1 and HPV18 L1. The results of the investigation of protein sequencing of 4 proteins L1 was shown that more likely antigenic determinant of $\mathrm{T}$ lymphocytes would be ones in the position 12-21 of the sequence. For HPV16 L1 - YLPPVPVSKV, for HPV31 L1 - YLPPVPVSKV, for HPV18 L1 YLPPPSVARV, for HPV45 L1 -YLPPPSVARV. Antigenic determinants of HPV16 L1 and HPV31 L1 were more closed to each other. The same similarity was found for HPV18 L1 and HPV45 L1. We assumed that the results of this investigation would be helpful for the creation of new perspective candidate vaccines against dangerous types of papillomaviruses. 


\title{
Genes determining dwarfism of watermelon Citrullus lanatus (Thunb.) Matsum. \& Nakai
}

\author{
Strygina K. ${ }^{1 *}$, Yanyshevskaya A. ${ }^{2}$, Elatskova A. ${ }^{3}$, Elatskov Yu. ${ }^{3}$, Tekhanovich G. ${ }^{3}$, \\ Khlestkina E. ${ }^{1}$ \\ ${ }^{1}$ Federal Research Center N.I. Vavilov All-Russian Institute of Plant Genetic Resources, St. Petersburg, \\ Russia \\ ${ }^{2}$ Pushkin Leningrad State University, St. Petersburg, Russia \\ ${ }^{3}$ Kuban Experiment Station of VIR, Krasnodar, Russia \\ * email: k.strygina@vir.nw.ru
}

Key words: Citrullus, Cucurbitaceae, dwarf genes, short vine, watermelon

Unlike many crops, the melon crops are characterized by the development of long vine that reaches 1.5 to $5 \mathrm{~m}$ in length, which makes harvesting difficult. Using methods of molecular genetics and marker-assisted selection, it is possible to create dwarf varieties growing in more northern latitudes, including beyond the Arctic Circle. The aim of this work is to identify and mark genes in the genome of watermelon Citrullus lanatus responsible for the formation of dwarf plant forms based on the unique collection of melon crops of the Federal Research Center N. I. Vavilov All-Russian Institute of Plant Genetic Resources (VIR). In genomes of Cucurbitaceae species, the search of homologous sequences of watermelon dwarf genes $d w-1$ (ABC transporter), $d s h$ (gibberellin 20-oxidase) and $d f$ (gibberellin 3-beta-hydroxylase) was performed. In genomes of Benincaseae species except for $C$. melo, one copy of $d w-1$ was identified, and in genomes of Cucurbiteae species and $C$. melo, two copies were found. The $d s h$ gene was identified in two copies in C. lanatus, in four copies in B. hispida, and in one copy in other analyzed species except for $C$. maxima and $C$. moschata, in which the gene was not identified. In C. lanatus, L. siceraria, and all Cucurbita species, and in B. hispida and all Cucumis species, two and three copies of $d f$ were found respectively. The allelic polymorphism was analyzed in genomes of VIR watermelon varieties. A total of 23 varieties and lines and 28 hybrids of $C$. lanatus were studied. A significant change in the motives, which could lead to changes in gene function, has been identified during sequencing in varieties with short and ultra-short vine.

Acknowledgments: The present study was supported by the VIR project No. 0481-20190001 . 


\section{Spring wheat varieties resistance to the common root rot}

Sukhomlinov V.Yu. ${ }^{1,3 *}$, Toropova E.Yu. ${ }^{1,2}$

${ }^{1}$ Novosibirsk State Agrarian University, Novosibirsk, Russia

${ }^{2}$ All-Russian Research Institute of Phytopathology, Moscow region, Russia

${ }^{3}$ Siberian Research Institute of Plant Production and Breeding - Branch of the Institute of Cytology and Genetics, SB RAS, Novosibirsk, Russia

*email: plantdef@bionet.nsc.ru

The purpose of the research was to identify resistant to the common root rot (Helminthosporium sativum Sacc.) spring wheat varieties from the collection of the Institute of Cytology and Genetics. The studies were carried out in 2020-2021 in the northern forest-steppe of the Ob region (West Siberia) using generally accepted methods. Among 15 varieties of spring wheat collection from different regions of Russia and countries of the world, no varieties were found that were not affected by common root rot. The zonal threshold of root rot harmfulness was exceeded to 3 times at the seedlings stage, and 3.7 times at the end of the growing season. The $H$. sativum part in the pathogenic complexes of spring wheat varieties root rot was $10-50 \%$ at the germination phase and $9-30 \%$ at the maturity phase. The rest of the pathogenic complexes were Fusarium Link. fungi. The varieties had a significant effect on $H$. sativum propagation on the basal leaves; the difference in the reproduction rate of the micromycete was 19 times for the varieties. By the end of the growing season, the H. sativum conidia population in the varieties rhizosphere soil increased by up to 55 times in comparison with the beginning of the growing season. The correlation coefficient between the $H$. sativum reproduction intensity on basal leaves and the conidia number in the soil was $R=0.890 \pm 0.127$ ( $p<0.01)$. The varieties were divided into groups according to their ability to stabilize the phytosanitary state of the soil: "altruists", limiting the development of foci of H.sativum in the soil (Sibirskaya 17, Zauralochka, Tobolskaya and Quarna), "egoists", significantly worsening the phytosanitary state of the soil for subsequent crops (Remus, Jin Chun 2 and K-65834), "neutral", occupying an intermediate position.

Acknowledgements: The reported study was funded by RFBR, project number 20-31690008. 


\section{VirHunter: a deep learning-based method for detection of novel viruses in plant sequencing data}

Sukhorukov G. ${ }^{1,2 *}$, Nikolski M. ${ }^{1,2}$

${ }^{1}$ University of Bordeaux, CNRS, IBGC, UMR 5095, Bordeaux, France

${ }^{2}$ University of Bordeaux, Bordeaux Bioinformatics Center, Bordeaux, France

*email: grigorii.sukhorukov@u-bordeaux.fr

Plant viruses are a major plant pathogen; plant infections by viruses result in more than $\$ 30$ billion losses a year. One of the best ways to fight against plant infections caused by viruses is the surveillance and early detection of viral presence in plant populations. For this task high-throughput sequencing (HTS) is often used as an excellent tool to investigate the viral presence in large plant samples. However HTS data comprises a mixture of sequences containing not only viral sequences but also contaminating sequences coming from the host and bacteria. The downstream bioinformatics analysis of these data can be difficult and time consuming. Moreover, computational tools often miss certain viruses present in the sample, especially the previously uncharacterised viral species. To help solve this task we have developed an artificial neural network approach that classifies sequences as belonging to viral, bacterial or plant host origin and is implemented in the Keras framework. The developed approach uses the one-hot encoding for both sequences and their reverse complement and relies on convolutional layers to learn k-mers distinguishing viral sequences. The network was trained on a dataset composed of three balanced classes corresponding to plant viruses, plants and bacteria. To be performant our VirHunter method has to be trained for the analysis of a specific plant's virome, as the training dataset is generated using the host information. We test our tool in different settings assessing its ability to detect novel viruses. Finally, we compare the performance of our tool to that of DeepVirFinder, a previously developed deep learning-based method for virus detection. 


\title{
Applications of the CRISPR/Cas9 genome editing system for modification of starch content in wheat and triticale
}

\author{
Timerbaev V. ${ }^{1,2,3 *}$, Miroshnichenko D. ${ }^{1,2,3}$, Bazhenov M. ${ }^{1}$, Klementyeva A. ${ }^{2,3}$, \\ Bespalova L.. ${ }^{4}$ Divashuk M.G. ${ }^{1,3}$, Karlov G. ${ }^{3}$, Kroupin P. ${ }^{1,3}$, Dolgov S..$^{2,3}$ \\ ${ }^{1}$ Kurchatov Genomic Center - ARRIAB, All-Russia Research Institute of Agricultural Biotechnology, \\ Moscow, Russia \\ ${ }^{2}$ Shemyakin and Ovchinnikov Institute of Bioorganic Chemistry RAS, Pushchino, Russia \\ ${ }^{3}$ All-Russia Research Institute of Agricultural Biotechnology, Moscow, Russia \\ ${ }^{4}$ Department of Breeding and Seed Production of Wheat and Triticale, National center of grain named \\ after Lukyanenko, Central Estate of KNIISH, Krasnodar, Russia \\ *email:timerbaev@gmail.com
}

Starch is the major component of mature cereal grains, representing more than $65 \%$ of its dried weight. The capacity for starch synthesis during grain filling can influence final grain weight, while the starch composition is an important factor for the technological and nutritional properties of flours. There is an increasing need to develop cereal crops with higher amylose content to improve human health and lower the risk of serious noninfectious diseases. Recent advances in technologies for genetic transformation and genome editing have opened up new perspectives for precise starch manipulation in cereals. In the present study, a CRISPR/Cas9 approach was used to modify the starch accumulation in two important cereal crops, such as emmer wheat (Triticum dicoccum) and triticale $(\times$ Triticosecale). Using a modular cloning system, two expression cassettes are designed to simultaneously knockout several genes involved in the grain starch composition and properties. Each polycistronic construct consists of six various corresponding sgRNAs under the control of the TaU3 wheat promoter to induce simultaneous indel mutation in such genes as the granule bound starch synthase (GBSSI), the starch branching enzyme (SBEIIa), the starch synthase (SSIIa), starch debranching enzymes of isoamylase (ISAI) and the starch regulator 1 (RSR1). Using a co-transformation strategy, polycistronic constructs were delivered by gene gun into morphogenic cereal cells together with an expression vector encoding the Cas 9 nuclease to achieve the mutagenesis. The generation of genome-edited plants demonstrating the targeted modifications of native genes will be discussed.

Funding: Kurchatov Genomic Center of All-Russia Research Institute of Agricultural Biotechnology, agreement No. 075-15-2019-1667. 


\section{Hairy roots characteristics of vegetable pea's morphotype with modified leaf and offspring of the 89/16 sugar line transformant}

Timina O.O. ${ }^{*}$, Timin O.Y. ${ }^{2}$, Stepanova A.Y. ${ }^{3}$, Solovyeva A.I. ${ }^{3}$

${ }^{1}$ Shevchenko State University, Tiraspol, Moldova, Transnistria

${ }^{2}$ Research Institute of Ecology and Natural Resources, Moldova, Transnistria, Bendery

${ }^{3}$ Timiryazev Institute of Plant Physiology, RAS, Moscow, Russia

*email: otimina@mail.ru

Genetic transformation of the vegetable pea has been tested by three wild strains of Agrobacterium rhizogenes. The steadily growing hairy roots of the acacia-shaped mutant were obtained free from the vector. PCR analysis showed the presence of rol $C$ gene in hairy roots with a total protein content of $46.38 \%$. The amino acid score protein identified seven essential amino acids. Tryptophan was absent in the culture, limiting the fullness of the protein. The vegetable sugar pea transformant was received, the offspring of which was also free from the vector. Plants PCR analysis showed the presence of rol $D$ gene in progeny, including the control variant. It is assumed that the control identified the appropriate homolog as a possible result of natural transformation, which occurred in natural conditions. The offspring of the transformant was characterized by both an increase in overall antioxidant activity and heat resistance in temperature stress $\left(25^{\circ} \leq \mathrm{t} \leq 49^{\circ} \mathrm{C}\right)$, which was assessed by direct method for the absence of leaves necrosis in comparison with control. Transformant's offspring was characterized by smaller leafs sizes and a decrease in the stem length, the lower bean height, the number of knots up to the lower bean and the dry mass of the plant. The results indicate an increase in the rate of reaction of the transformant offspring, which has become consistent with the mesothermophyte (heat-loving) ecogroup in comparison with control. This adaptation may be based on the active expression of the rol $D$ gene, which is known to encode an enzyme that synthesizes proline, an amino acid with antioxidant, anti-denature osmoregulating properties and membrane-protective properties that adapt to stress. It is assumed that the mechanism of increasing the antioxidant activity of transformants is associated with an increase in the number of copies of the rol $D$ gene. 


\section{The influence of alien translocations on in vitro androgenesis in lines of spring common wheat}

Timonova E.M. ${ }^{1,2 *}$, Adonina I.G. ${ }^{1,2}$, Salina E.A. ${ }^{2}$

${ }^{1}$ Institute of Cytology and Genetics, SB RAS, Novosibirsk, Russia

${ }^{2}$ Kurchatov Genomic Center of the Institute of Cytology and Genetics, SB RAS, Novosibirsk, Russia

*email:eegorova@bionet.nsc.ru

Androgenesis is potentially the most effective technique for doubled haploid production of wheat. However, it is not widely used in breeding programs due to its main limitation: the genotype dependence. The basic approach to the production of new genotypes of wheat is introgressive hybridization and enrichment of the Triticum aestivum L. gene pool by genes from different species of goat grass, wheatgrass, rye and other relatives. Due to genetic differences between wheat and related species, it was assumed that alien genetic material is different in their capacity to conduct androgenesis. The aim of this work was to develop a set of doubled haploid (DH) wheat lines containing alien translocation and to study their influence on the ability to androgenesis in anther culture of those lines. In the experiment we used: cultivar Novosibirskaya 16, line 991 carrying translocations 1RS.1BL from rye and 5BS.5BL-5SL from Aegilops speltoides and four hybrid $F_{3}$ generation lines $(10-7,14-8,15-8,15-12)$ from their crossing and differing in the content of foreign translocations. A total of 4770 anthers were tested. It was shown that parameters of androgenesis such as the number of embryo-like structures, the total number of regenerants, and the number of green regenerants per 100 anthers varied depending on line. The best-responding lines $991,10-7$ and 14-8 are characterized by the presence of $1 \mathrm{RS} .1 \mathrm{BL}$ wheat-rye translocation chromosome. Regeneration frequency of green plants was recorded to be 4,0,4,2 and 11,3\% respectively. It could be concluded that short arm of the chromosome 1R carries genes that stimulates androgenesis in anther culture. Frequency of albino plants for the cultivar Novosibirskaya 16 was high $(7,2 \%)$ opposite to frequency of green plants $(0,2 \%)$. Spontaneous doubled haploids, verified by cytological analysis of chromosome number and by the measurement of stomata guard cell length, were found in $39,1 \%$ of plants.

Acknowledgements: This work was done within the framework of State Assignment Kurchatov Genomic Center of the Institute of Cytology and Genetics, SB RAS (075-152019-1662). 


\section{Transcriptomic analysis of radish (Raphanus sativus L.) spontaneous tumors}

Tkachenko A.A. ${ }^{1,2}$, Dodueva I.E. ${ }^{1}$, Tvorogova V.E. ${ }^{1}$, Predeus A.V. ${ }^{3}$, Pravdina O.Yu. ${ }^{1}$, Kuznetsova K.A. ${ }^{1 *}$, Lutova L.A. ${ }^{1}$

${ }^{1}$ Department of Genetics and Biotechnology, Saint-Petersburg State University, St. Petersburg, Russia

${ }^{2}$ Laboratory of Computer Technologies, ITMO University, St. Petersburg, Russia

${ }^{3}$ Bioinformatics Institute, St. Petersburg, Russia

*email: kskuz95@mail.ru

Spontaneous tumorigenesis is a process that occur without any pathogen infection in different organs of various plant species. In higher plants, spontaneous tumors are uncommon other than pathogen-induced tumors, such as crown gall induced by Agrobacterium, and consequently less investigated. Several studies of spontaneous tumors in plants revealed that such tumors, as a rule, appear in plants with genotypes of mutants and interspecific hybrids. In radish, Raphanus sativus L., spontaneous tumors originate from the pericycle and cambium cells (Ilina et al., 2006; Lebedeva et al., 2015) which brings them closer to the lateral and adventitious roots. The inbred lines of radish (Raphanus sativus var. Radicula Pers) develop spontaneous tumors on the taproot during the flowering period. Among these lines, the connection between the spontaneous tumor development and the altered balance of the main phytohormones, as well as ectopic expression of meristem-specific genes, was previously demonstrated. In this work, we analyzed the differential gene expression in the radish spontaneous tumors versus the lateral roots using the RNA-seq method. Analysis of GO categories revealed that most enriched upregulated pathways in spontaneous tumors were associated with cell division and expansion, especially genes that regulate G2-M transition and cytokinesis. Among downregulated pathways, the ones involved in stress and wounding response, as well as in the production of JA and glucosinolates, were overrepresented. Our data may help to elucidate the mechanisms of spontaneous tumor development in higher plants.

Acknowledgements: This work was supported of the Ministry of Science and Higher Education of the Russian Federation in accordance with agreement No. 075-15-2020922 date 16.11.2020 on providing a grant in the form of subsidies from the Federal budget of Russian Federation. The grant was provided for state support for the creation and development of a World-class Scientific Center "Agrotechnologies for the Future". 


\title{
Methylome profiling of guar isogenic lines (Cyamopsis tetragonoloba (L.) Taub.) in different growing conditions using ONT technology
}

\author{
Tkachenko A.A. ${ }^{1 *}$, Ulianich P.S. ${ }^{2,3}$ \\ ${ }^{1}$ ITMO University, St. Petersburg, Russia \\ ${ }^{2}$ All-Russian Research Institute of Agricultural Microbiology, St. Petersburg, Russia \\ ${ }^{3}$ Sirius University of Science and Technology, Sochi, Russia \\ *email:aatkachenko@itmo.ru
}

Guar (Cyamopsis tetragonoloba (L.) Taub.) is an annual legume plant serving as the source of guar gum, a polymeric compound containing galactose residues and possessing thickening and stabilizing properties useful in food, feed, and industrial applications. About $80 \%$ of world guar production occurs in India and, since the demand for guar gum is ever growing, guar is actively studied for the purpose of its introduction to other countries. Plant growth is characterized by sensitivity to the length of daylight hours, and guar grows well in the subequatorial zone with short day conditions. However, when introduced to regions with longer daylight hours, it has difficulties with entering the flowering phase and, as the result, beans do not have time to form and mature. Therefore, understanding the mechanism of guar sensitivity to day length is crucial for its adaptation to northern latitudes and this study investigates the methylation profile of guar in different growing conditions. A vegetation experiment was carried out where the plants grew at different lengths of daylight hours. In addition, guar forms a symbiotic relationship with nitrogen-fixing bacteria, which also accelerates the growth rate of the plant. Thus, some of the plants in the vegetation experiment were inoculated with a bacterial strain obtained as a result of an expedition to India. Methylation profile of plants was analyzed with nanopore sequencing technology (ONT) and differentially methylated loci and regions were found and analyzed.

Acknowledgements: The reported study was funded by RFBR, project number 19-31651007. 


\title{
Spring wheat varieties resistance to biotic stressors
}

\author{
Toropova E.Yu. ${ }^{1,2 *}$, Trunov R.I. ${ }^{1}$, Piskarev V.V. ${ }^{3}$ \\ ${ }^{1}$ Novosibirsk State Agrarian University, Novosibirsk, Russia \\ ${ }^{2}$ All-Russian Research Institute of Phytopathology, Moscow region, Russia \\ ${ }^{3}$ Institute of Cytology and Genetics, Siberian Branch of the Russian Academy of Sciences, Novosibirsk, \\ Russia \\ * email: $89139148962 @ y a n d e x . r u$
}

The purpose of the research was to identify resistant to a complex of biotic stressors pathogens of soil infections (Helminthosporium sativum Sacc., Fusarium spp. Link.) and cereal flies (Oscinella pusilla Mg., Phorbia genitalis Schnalb., Mayetiola destructor Say.) spring wheat varieties from the collection of the Institute of Cytology and Genetics. The studies were carried out in 2020-2021 in the northern forest-steppe of the Ob region (West Siberia) using generally accepted methods. Among 20 varieties of spring wheat collection from different regions of Russia and countries of the world, no varieties were found that were not affected by root rot and were not damaged by pests. The zonal threshold of root rot harmfulness was exceeded to 5 times. The difference in the varieties infestation by root rot was 2.3 times at the seedlings stage, and 1.5 times at the end of the growing season. The significant differences in the root rot etiology in varieties were revealed, which was due to the specific induction by varieties of the rhizosphere soil suppressiveness to the pathogenic micromycetes species. The correlation coefficient of the soil suppressiveness induction to Fusarium poae by varieties and its representation in root rot pathogenic complexes was $R=-0.638 \pm 0.318$, the same correlation coefficient to Fusarium oxysporum was $R=-0.844 \pm 0.203(P<0.01)$. Damage to spring wheat main stems by cereal flies reached 10 thresholds and varied by varieties to 3.7 times. The correlation coefficient between the root rot incidence and stems damage by cereal flies was $R=0.713 \pm 0.092$. Under conditions of massive damage by cereal flies, the varieties could not fully manifest genetically determined immune properties, especially in the second half of the growing season.

Acknowledgements: The reported study was funded by RFBR, project number 20-01600079. 


\section{Markers of somatic embryogenesis of Pinaceae species in in vitro culture (cytohistological, physiological and molecular genetic)}

Tretyakova I.N.*, Park M.E.

V.N. Sukachev Institute of Forest SB RAS, Federal Research Center "Krasnoyarsk Science Center SB

RAS" Siberian Branch of the Russian Academy of Science, Krasnoyarsk, Russia

*email: culture@ksc.krasn.ru

Somatic embryogenesis in in vitro culture is an ideal model for studying cytohistological, physiological, and molecular genetic events that occur during the embryogenesis of a tree organism. The first peculiarity of embryogenic culture (EC) in Pinaceae species is the elongation, polarization, and asymmetric division of somatic cells, as well as the localization of IAA at one end of the elongated cell. Further, a well-developed embryogenic tissue is formed, represented by the embryonal-suspensor mass (ESM), in which there is an active formation of globular somatic embryos through cleavage. In contrast to EC, non-embryogenic calli (NEC) consist of isodiametric, actively dividing cells. ESM of Larix sibirica contains a high content of IAA (100 times more than in NEC) and a low content of ABA. Reading of transcriptomes of EC and NEC in the culture in vitro of Larix sibirica by automated processing showed that the greatest differences in the level of expression of EC are characterized by proteins responsible for the regulation of physiological functions and associated with the development of the embryo. Thus, the markers of somatic embryogenesis of Pinaceae species are: polarization and asymmetric division of elongated cells, formation of ESM, localization of IAA in the elongated cell, high content of IAA in the ESM, as well as the presence of proteins responsible for physiological functions and embryogenesis.

Acknowledgements: The reported study was funded by Russian Foundation for Basic Research, Government of Krasnoyarsk Territory, Krasnoyarsk Region Science and Technology Support Fund to the research projects number 19-44-240009. 


\title{
Genetic diversity of peach from the collection of the Nikita Botanical Gardens revealed by SSR markers
}

\author{
Trifonova A.A. ${ }^{1,2}$, Boris K.V. ${ }^{1,2 *}$, Tsyupka V.A. ${ }^{1,3}$, Smykov A.V. ${ }^{3}$, \\ Mitrofanova I.V.1,3 \\ ${ }^{1}$ Kurchatov Genomic Centre - NBG-NSC, Yalta, Russia \\ ${ }^{2}$ Vavilov Institute of General Genetics RAS, Moscow, Russia \\ ${ }^{3}$ The Labor Red Banner Order Nikita Botanical Gardens - National Scientific Center of the RAS, Yalta, \\ Russia \\ *email:docboris@mail.ru
}

The peach collection of the Nikita Botanical Gardens (NBG-NSC) includes more than 600 peach, nectarine and ornamental peach accessions. Currently, to assess genetic diversity and structure of plant germplasm collections and for genotyping individual accessions molecular markers, especially microsatellites (SSR), are widely applied. Still, there were no large-scale studies of the NBG-NSC peach collection using SSR markers. To study genetic diversity of 76 peach (Prunus persica L.) cultivars from the NBG-NSC collection, ten SSR markers were used. Analysis was performed on ABI Prism 3130xl (Applied Biosystems). The detected polymorphism level was rather low: 4.9 alleles per locus were identified (from 2 (UDP97-402, UDP98-405) to 7 (UDP96-005, BPPCT025)), polymorphic information content value averaged 0.424 , expected and observed heterozygosity averaged 0.459 and 0.257 respectively. Twelve rare $(24.5 \%)$ and seven unique alleles $(14.3 \%)$ were detected. In the analyzed peach collection 68 unique genotypes were identified. Seven groups (15 accessions) with an identical set of alleles were found which can be duplicates or closely related genotypes. Cluster analysis based on Dice genetic similarity coefficient did not reveal differentiation of the studied accessions based on their country of origin (cultivars bred in NBG-NSC, USA, Armenia and etc) and ecological-geographic group (North Chinese, South Chinese, Iranian), but revealed two mixed clusters with several subclusters based on the cultivars pedigrees. The study of the genetic structure of the collection revealed three clusters: the first cluster consisted of seven cultivars bred in NBG-NSC, two other clusters included cultivars of different origin. The same seven NBG-NSC cultivars differentiated from other studied accessions according to the results of the principal coordinates analysis.

Acknowledgements: This study was supported by the grant No. 075-15-2019-1670 from Ministry of Science and Higher Education of the Russian Federation. 


\title{
Genetic diversity of old and local apple cultivars of North Caucasus from VIR collection based on SSR markers
}

\author{
Trifonova A.A. ${ }^{1 *}$, Shlyavas A.V. ${ }^{2}$, Boris K.V. ${ }^{1}$, Kudryavtsev A.M. ${ }^{1}$ \\ ${ }^{1}$ Vavilov Institute of General Genetics Russian Academy of Sciences, Moscow, Russia \\ ${ }^{2}$ N.I. Vavilov All-Russian Institute of Plant Genetic Resources (VIR), St. Petersburg, Russia \\ *email:aichka89@mail.ru
}

At the Maikop Experiment Station of VIR a collection of about 160 old and local apple cultivars is maintained, including 41 cultivars from North Caucasus collected during the research expeditions since 1930. These cultivars are known for their ecological plasticity, stable yield, durability and disease and pests resistance. No genetic diversity studies of the collection were previously carried out. To study genetic polymorphism of 41 North Caucasus old and local apple cultivars, ten SSR markers were used. Analysis was performed on ABI Prism 3130xl (Applied Biosystems). We found three genotypes with three alleles at more than one locus, therefore considering them as triploids (Vegetativnoe silnorosloe, Kihar ich Zimniy, Funtovka).Two accessions had identical SSR profiles (Tyazhelka \# 1 and Tyazhelka \# 2). A high level of polymorphism of North Caucasus cultivars was revealed. For diploids, 113 alleles were detected. The number of alleles per locus varied from $6(\mathrm{CHO} 2 \mathrm{CO} 2 b)$ to $20(\mathrm{CHO} 2 \mathrm{cO} a \mathrm{a})$ and averaged 11.3. The polymorphic information content (PIC) ranged from $0.63(\mathrm{CHO2cO2b})$ to 0.91 $(\mathrm{CHO2cO2a})$. The average expected heterozygosity $\left(\mathrm{H}_{\mathrm{e}}\right)$ was 0.81 . High frequency of rare $(13.3 \%)$ and unique $(30.1 \%)$ alleles was detected. Dice genetic similarity coefficient varied from 0.88 (for Kihar ich Letniy and Hruk ich Letniy) to 0 (for 13 pairs of studied accessions) and averaged 0.26 . Cluster analysis did not reveal clear differentiation of the studied cultivars based on their origin except for seven accessions from Dagestan. Thus, the analyzed collection of old and local North Caucasus apple cultivars showed high genetic diversity and the obtained data may be used for SSR genotyping of the accessions.

Acknowledgements: The work was supported by RFBR project No. 17-29-08020. 


\title{
Molecular-genetic analysis of genome incompatibility in wheat-rye hybrids
}

\author{
Tsvetkova N.V. ${ }^{1}$, Zykin P.A. ${ }^{1}$, Andreeva E.A. ${ }^{1,2}$, Hackauf B. ${ }^{3}$, Voylokov A.V. ${ }^{2}$ \\ ${ }^{1}$ St. Petersburg State University, St. Petersburg, Russia \\ ${ }^{2}$ Vavilov Institute of General Genetics RAS, St. Petersburg, Russia \\ ${ }^{3}$ Julius Kühn-Institut, Institute for Breeding Research on Agricultural Crops, Sanitz, Germany \\ *email: n.tswetkowa@spbu.ru
}

The post-zygotic reproductive isolation in plants is frequently based on the negative interaction of the parental genes involved in plant development. The interaction of genes is the basis of the canonical scheme (Bateson-Dobzhansky-Muller model), explaining the emergence and functioning of post-zygotic incompatibility. Linkage analysis of microsatellite loci, as well as genes of embryo lethality (Eml-R1) and hybrid dwarfness (Hdw-R1), was performed in hybrids of Chinese Spring wheat with recombinant inbred lines as well as interline rye hybrids (Tsvetkova et al., 2018). Eml-R1 and Hdw-R1 has been mapped proximally and distally of two closely linked EST-SSR markers, Xgrm0902 and Xgrm0959, on the rye chromosome 6R which contains a breakpoint of evolutionary translocation between the ancestral chromosomes of homeologous groups 6 and 3. We have performed bioinformatic search of candidate genes in this region using transcripts isolated from tis-sues of the inbred rye line L7 from Petergof genetic collection. The assembly of the transcripts was done with SpaDeS. Each of the ESTderived SSR markers Xgrm0959, Xgrm0902 and mRNA sequences were mapped on chromosome-scale genome assembly (Rabanus-Wallace et al., 2021). The area of chromosome 6 between the markers contains sequences for transcription factors of two types: bHLH and Myb. Sequence similarity search in wheat and barley genome databases revealed orthologs of rye genes SECCE6Rv1G0419580.1 (bHLH) and SECCE6Rv1G0427780.1 (Myb) annotated as genes participating in plant development. Future transcriptomic analysis of the mutant lines will allow to understand the role of supposed candidate genes in interspecies isolation. 


\section{Differential gene expression in Lavandula angustifolia Mill. under adaptation ex vitro}

Tsyupka V.A.*, Kuleshova O.N., Emirsaliev A.O., Zhdanova I.V., Mitrofanova I.V. Federal State Funded Institution of Science "The Labor Red Banner Order Nikita Botanical Gardens National Scientific Center of the RAS", Nikita, Yalta, Russia

*email:valentina.brailko@yandex.ru

Propagation of commercial lavender (Lavandula angustifolia Mill.) cultivars in vitro has a number of advantages over seed or vegetative (cuttings) propagation: obtaining a uniform, genetically stable and healthy planting material. At the same time, the effectiveness of this process depends on the subsequent adaptation of the obtained plants to the open-field conditions. The research was carried out on the 'Prima' cultivar in the collection of the Nikita Botanical Gardens. Leaves were collected from plants grown in vitro before transferring them to in vivo conditions and from plants after 7 days adaptation in a Conviron multilevel plant growth chamber (Canada). Lavender plants were cultured in vitro on MS culture medium supplemented with $0.5 \mathrm{mg} / \mathrm{L} \mathrm{BAP}$ or $0.5 \mathrm{mg} / \mathrm{L}$ kinetin and $0.025 \mathrm{mg} / \mathrm{L} \mathrm{NAA}$ at a temperature of $22-25{ }^{\circ} \mathrm{C}, 14-16$-hour photoperiod, light intensity $-25.0-37.5 \mu \mathrm{mol} \mathrm{m} \mathrm{m}^{-2} \mathrm{~s}^{-1}$. To induct rhizogenesis (after third passage). MS medium with different content of auxins, IBA or NAA $(0.5-1.0 \mathrm{mg} / \mathrm{L})$, was used. To analyze possible molecular mechanisms, which are the base of the adaptive processes in plants, at the time of transition from in vitro growth to in vivo growth the sampels of total RNA were isolated from leaves by the NucleoSpin RNA Plant protocol (NucleoSpin, Germany) and 24 barcoded RNA-Seq libraries were created using Illumna TruSeq Stranded mRNA Library Prep Kit. Sequencing was made on a high-performance sequencer Illumina NextSeq 550 using the NextSeq 500 HighOutputv2 Kit with an estimated capacity of at least 90 million reads. As a result of sequencing, 3 libraries of transcriptomic data were obtained for each of the states (in vitro and in vivo). For the obtained data, pre-preparation, de novo transcriptome assembly, transcript-level expression analysis, search for protein-coding regions and their annotation using the SwissProt Viridiplantae database, and evaluation of differential expression were made. The transcripts of up-regulation and down-regulation have been identified. The following software packages were used: FastP v. 0.19.5, Trinityv.2.11.0, Kallistov.0.46.1, TransDecoder v.5.5.0, BLASTv.2.11.0, edgeRv.3.32.1.

Acknowledgements: The studies were funded by research grant No.19-76-00023 of the Russian Science Foundation and SA No. 0829-2019-0038 of the FSFIS "NBG-NSC" on the basis of the Unique Scientific Installation "FITOBIOGEN" FSFIS "NBG-NSC". 


\section{The search of somatic embryogenesis regulators in Medicago truncatula}

Tvorogova V.E.*, Baltin S.M., Krasnoperova E.Y., Potsenkovskaia E.A., Yakovleva D.V., Zlydneva N.S., Lutova L.A.

St. Petersburg State University, St. Petersburg, Russia

*email: krubaza@mail.ru

Somatic embryogenesis (SE) as a regeneration pathway is widely used in plant biotechnology for genetic modification and genome editing. The investigation of SE regulators is important for the development of new efficient protocols of plant regeneration. In recent several years, a number of morphogenic regulators were found among plant transcription factors, whose ectopic expression can stimulate SE or, in some cases, can make it possible. WUSCHEL homeodomain-containing protein from the WOX family is the most well-known example of such SE stimulator. Previously in our research, we found that ectopic expression of another gene from the WOX family, MtWOX9-1, can stimulate SE in Medicago truncatula. The aim of our present research is to find out the main factors, related to MtWOX9-1 in the regulatory network controlling SE. Phylogeny and expression analysis allowed us to find other WOX genes which can possibly act redundantly with MtWOX9-1 during SE. As far as WOX genes are known to be regulated by CLAVATA systems, we searched for CLE peptide which could suppress or activate MtWOX9-1 expression and, therefore, to suppress or stimulate SE itself. We found two possible SE regulators among CLE genes. Using transcriptome and ChIP analysis, we also search for MtWOX9-1 direct targets.

Acknowledgements: The research was made with support of the Ministry of Science and Higher Education of the Russian Federation in accordance with agreement No. 075-152020-922 date 16.11.2020 on providing a grant in the form of subsidies from the Federal budget of Russian Federation. The grant was provided for state support for the creation and development of a World-class Scientific Center "Agrotechnologies for the Future". 


\title{
Structural characterization and expression of new gene homologs of GDP-D-mannose-3', 5'-epimerase GME1 in wild and cultivated tomato species
}

\author{
Tyapkina D.Y.*, Slugina M.A. \\ Federal Research Centre "Fundamentals of Biotechnology" RAS, Moscow, Russia \\ * email: daria_t@list.ru
}

GDP-D-mannose epimerase (GME) is considered to be the central enzyme connecting the ascorbate biosynthesis pathway to primary cell wall metabolism. GME1 plays an important role in ascorbate accumulation in leaves and fruits and also is involved in the cell wall and glycoproteins biosynthesis during growth of vegetative organs. In this work, GME1 homologous genes were identified and characterized in 10 cultivated and wild tomato species and the GME1 expression analysis during fruit development and ascorbate accumulation was carried out.

All identified tomato GME1 homologs included six exons; gene length varied from 1962 bp (S. galapagense) to 1985 bp ( $S$. peruvianum), due to InDels in exon sequences. Comparison with the reference genome revealed 136 SNPs and 22 InDels in GME1 homologs Moreover, 134 SNPs were found in green-fruited tomato species and only 5 SNPs in red-fruited species. Five SNPs (T294C, T738A, T783C, T1746A, and C1967T) and 1259ins9 InDel were found to correlated with the genotype of crosspollinated tomato species.

Analysis of the GME1 amino acid sequences revealed only two substitutions, G2E and E281D, which were present only in green-fruited species, but they did not correlate with the levels of ascorbate accumulation in fruits.

GME1 expression analysis in various plant organs of red-fruited and green-fruited accessions revealed the highest transcription levels in the leaves and the lowest in the roots. Comparative analysis between ascorbate content and expression levels in mature fruits in ten S. lycopersicum cultivars and two green-fruited tomato species contrasting in ascorbate content showed no correlation. A comparative analysis of four fruit development stages, ascorbate content and GME1 expression levels showed the maximum number of transcripts in young fruits with a gradual decrease in the expression level to the stage of biological ripeness; this dynamics was opposite to ascorbate accumulation. It is possible that in an intensively growing young fruit, the GME1 enzyme is more actively involved in the process of cell growth rather than in the ascorbate biosynthesis. 


\title{
Subcompartmented oxphosomic model of the mitochondrial oxidative phosphorylation system
}

\author{
Ukolova I.V. \\ Siberian Institute of Plant Physiology and Biochemistry SB RAS, Irkutsk, Russia \\ *email: irina@sifibr.irk.ru
}

Mitochondria are vital organelles that provide the cells of aerobic eukaryotic organisms with energy in the form of ATP via oxidative phosphorylation system (OXPHOS). OXPHOS enzymes (complexes I-V) are located in the inner mitochondrial membrane, mainly in cristae domain. At present, there is a large amount of experimental data indicating that the respiratory complexes $\mathrm{I}_{1} \mathrm{III}_{2}$ and IV in vivo can physically interact in different stoichiometry, thereby forming supercomplexes (SCs). The current models of supramolecular organisation of OXPHOS are contradictory and suggest either highly ordered respiratory strings or, vice versa, a set of randomly dispersed respiratory complexes and SCs. As for ATP synthase (also called as complex V), it is assumed that it does not form associations with respiratory complexes and SCs and works autonomously. Recently, while studying the OXPHOS arrangement in pea shoot mitochondria, we found for the first time, that complex IV and ATP synthase can interact and form the $\mathrm{IV}_{1} \mathrm{Va}_{2}$ supercomplex (Ukolova et al., 2020). In addition to this SC, other new structures, that had not been detected earlier, were also revealed. These findings suggested that all enzymes of the OXPHOS system in vivo could form a single superstructure called as 'oxphosome'. Taking into account phylogenetic conservation of supercomplex organisation as well as our findings and currently available highresolution structures of respiratory complexes and SCs, a subcompartmented oxphosomic model of the mitochondrial energy transduction system has been developed. According to this model, a significant part of the OXPHOS complexes form oxphosomes, which are located mainly in the cristal subcompartment of mitochondria as highly organised 'strings' or 'patches', which are in fact 'mini factories' for ATP production. Such organisation significantly increases the efficiency of the OXPHOS system, since it enables the use of not only protons of the bulk phase of the intermembrane space, but also protons associated with the membrane and produced in high local concentrations by respiratory enzymes of oxphosomes. 


\title{
Allelic diversity of gliadin-coding loci of common wheat (Triticum aestivum $\mathbf{L}$.) of Siberian and Kazakh breeding
}

\author{
Utebayev M.U. ${ }^{1,2 *}$, Bome N.A. ${ }^{2}$, Chilimova I.V. ${ }^{1}$, Kradetskaya O.O. ${ }^{1}$, \\ Dolinny Y.Y. ${ }^{1}$, Weisfeld L.I. ${ }^{3}$ \\ ${ }^{1}$ A.I. Barayev Research and Production Centre of Grain Farming, Shortandy-1, Kazakhstan \\ ${ }^{2}$ Institute of Biology, University of Tyumen, Tyumen, Russia \\ ${ }^{3}$ Emanuel Institute of Biological Chemistry of the Russian Academy of Sciences, Moscow, Russia \\ *email: phytochem@yandex.ru
}

Genetic control of gliadin is carried out by six main clusters of genes Gli-1, Gli-2, localized in the short arms of chromosomes 1 and 6 of the homeologous groups. The aim of the study is identification and comparative analysis of cultivars and lines of spring soft wheat of Kazakhstan and Siberian selection based on gliadin electrophoresis in acidic aluminum lactate buffer. According to the results of electrophoresis of 139 samples of the wheat of Siberian and Kazakhstan breeding, the genetic formulas of gliadin were compiled. Gliadin polymorphism was established in Russian (37\%) and Kazakhstan (26\%) wheat. The frequency of the Gli-Alf allele in the grain of Kazakhstani samples was $47.4 \%$, Russian - 46.9\%. At the Gli-Bl locus, the Gli-Ble allele dominated in Kazakhstan wheat with a frequency of $72.0 \%$; among the samples of Siberian selection, the alleles Gli-Blb (43.7\%), Gli-Ble (30.8\%) were more common. Locus GliD1 carries the common Gli-Dla allele for both groups: $61.7 \%$ in Kazakhstan and $61.0 \%$ in Russian. At the loci of the 2 homeologous group, the following alleles prevailed in Russian wheat: Gli-A2l (17.0\%), Gli-A2m (16.9\%), Gli-B2o (16.1\%), Gli-B2r (14.5\%), Gli-D2q (19.8\%), and Gli-D2a (17.7\%). The same alleles dominated in Kazakhstan wheat: Gli-A2l (25.3\%), Gli-A2s (16.2\%), Gli-B2r (25.7\%), Gli-D2a (40.3\%). The genetic diversity index $(H)$ for both groups was 0.45 (Gli-B1, Kazakhstan) and 0.91 (Gli$B 2$, Siberia). The highest $H$ value at the Gli-B2 locus is associated with the maximum number of identified alleles. Information about the allelic state of gliadin-coding loci in wheat contributes to the targeted selection of genotypes with the association of alleles associated with valuable traits. 


\title{
Tomato plants carring $p p h 6$ gene for phytoremediation
}

\author{
Vershinina Z.R.*, Khakimova L.R., Chubukova O.V. \\ Institute of Biochemistry and Genetics - Subdivision of the Ufa Federal Research Centre of the Russian \\ Academy of Sciences, Ufa, Russia \\ *email: zilyaver@mail.ru
}

Phytoremediation is the elimination, neutralization or conversion of pollutants to a less toxic form with the help of plants. This method is often used for heavy metal (HM) contaminated soils. It is important to select suitable plants - hyperaccumulators of HM to restore the biological productivity of ecosystems. Tomato is widely cultivated in agriculture. In recent years, studies on the accumulation of HM in tomato plants and the potential use of tomatoes for phytoremediation have become popular. It is known that phytochelatins protects plant cell from HM harmful effect and results in accumulation of metals in plant in low toxic form. Phytochelatins contain a gamma peptide bond, therefore, the use of pseudophytochelatins with an alpha peptide bond is relevant in biotenology. Vector constructs for the transformation of plants with the pph6 pseudophytochelatin gene were obtained. Artificially synthesized pph6 gene assembled from complementary blocks 5'ATGGAATGCGAATGTGAGTGCGAGTGCGAGTGCGAATGTGGCTAA3 'and 5'TTAGAGACACTCTCGCACTCGCACTCGCAT. After stitching these blocks, the sequence was cloned into a vector for plant transformation pCambia 1301 under the control of the $35 \mathrm{~S}$ promoter of the cauliflower mosaic virus and and later used to obtain transgenic tomato plants by agrobacterium transformation method. Then, the positive effect of the expression of the pph6 gene on the resistance of transformed plant tissue cultures to the effects of heavy metals $\left(\mathrm{Cd}^{2+}\right.$ and $\left.\mathrm{Ni}^{2+}\right)$ was shown. Thus, a system of agrobacterial transformation of the industrial variety of tomato plants Gruntovy Gribovsky 1180 with the pseudophytochelatin pph6 gene was developed, which made it possible to obtain plants that would potentially efficiently accumulate heavy metals for further use in phytoremediation.

Acknowledgements: This work was performed as a part of State Assignment No. AAAAA21-121011990120-7; it was financially supported by the Russian Foundation for Basic Research, project No. 18-34-20004 mol_a_ved. 


\title{
Hormonal control of root growth and development in ABA deficient barley mutant
}

\author{
Veselov D.*, Vysotskaya L., Timergalina L., Fedyaev V. \\ Ufa Institute of Biology, UFRC RAS, Ufa, Russia \\ *email:veselov@anrb.ru
}

Phytohormone abscisic acid (ABA) plays important role in the control of plant development. Its accumulation under stress conditions is involved in plant adaptation to changing environment. Genetic control of ABA synthesis is thoroughly studied and mutations of the genes responsible for the process have been shown to lead to the hormone deficiency in planta. We worked with barley mutant AZ34 with impaired function of the molybdenum cofactor of the enzyme catalyzing oxidation of ABA aldehyde. Its comparison with the parental barley cultivar Steptoe allowed revealing the importance of this hormone for regulation of root growth and development. We studied the effects of over-optimal concentrations of mineral nutrients resulting in mild osmotic stress on root growth and cytokinin concentration in plants of both genotypes. Interest to cytokinins was dictated by information on importance of interaction between cytokinins and $\mathrm{ABA}$ for the control of plants responses to availability of mineral nutrients. Increased concentration of mineral nutrients resulted in inhibition of root elongation accompanied by accumulation of cytokinins in roots of Steptoe plants. Root growth response was likely to be due to accumulation of cytokinins detected in the stressed plants, since these hormones are known to inhibit root growth. Both hormonal and growth response were absent in the ABA deficient mutant suggesting importance of capacity of the plants to accumulated ABA for the control of cytokinin concentration in the roots and inhibition of their elongation under mild osmotic stress. Accumulation of cytokinins in the roots of Steptoe was accompanied by a decline in their concentration in the shoots suggesting inhibition of cytokinin export from root to shoots under osmotic stress caused by excessive concentration of mineral nutrients. We hypothesize that detected changes in cytokinin distribution between roots and shoots are due to ABAinduced inhibition of cytokinin transport from the roots.

Acknowledgments: The work was supported by grant No. 20-04-00305 of RFBR. 


\title{
Different resistance of bread wheat near-isogenic lines carrying various combinations of alleles of the $P p$ and $B a$ genes regulating the biosynthesis of anthocyanin to the pathogenic fungus Stagonospora nodorum
}

\author{
Veselova S.V. ${ }^{1 *}$, Shoeva O.Y. ${ }^{2}$, Nuzhnaya T.V. ${ }^{1}$, Burkhanova G.F. ${ }^{1}$, Rumyantsev S.D. ${ }^{1}$ \\ ${ }^{1}$ Institute of Biochemistry and Genetics of the UFRC of the RAS, Ufa, Russia \\ ${ }^{2}$ Institute of Cytology and Genetics, SB RAS, Novosibirsk, Russia \\ * email: veselova75@rambler.ru
}

In recent years, there has been an increasing interest in the production of wheat, which accumulates anthocyanin compounds in grain, as a source of useful food products. However, the significance of these substances for wheat plant protection has not been sufficiently estimated yet. We used a set of nearly isogenic (NILs) and substitution lines carrying various combinations of dominant and recessive alleles of the $P p$ and $B a$ genes, which regulate the biosynthesis of anthocyanins in the pericarp/coleoptile and aleurone layer respectively. The lines have been developed in the genetic background of spring bread wheat (Triticum aestivum L.) Saratovskaya 29 (S29). Variety S29 and the lines were infected with two isolates of the pathogenic fungus Stagonospora nodorum carrying a different set of necrotrophic effectors Sn9MN (ToxA/Tox3/Tox1) and Sn1SP (Tox1). We found the Snnl susceptibility gene to the $S$. nodorum effector SnTox1 in variety S29 and the lines. The variety S29 showed susceptibility to the Sn9MN isolate and resistance to the Sn1SP isolate. Lines iP2A, iP7D, iP were more susceptible to both isolates of the pathogen than S29. Lines iJP7A, iPF7D and substitution line s:S29Ba, were more resistant to both isolates of the pathogen than S29. The lines iPF2A, iPF showed the greatest resistance among the other lines. A gain in the resistance of each individual line was accompanied by intensification in the generation of hydrogen peroxide, an increase in the activity of peroxidases, and a change in the expression of the Snnl gene at an early stage of infection with the pathogen (up to 3 days). Such a different degree of NILs resistance to $S$. nodorum may be due to differences in the composition of introgressed genomics fragments.

Acknowledgments: This work was supported by the RFBR project No. 20-316-80047. 


\title{
Study of melanin and anthocyanin biosynthesis regulation in barley grain by transcriptomic analysis of near-isogenic lines with different pigment composition
}

\author{
Vikhorev A.V. ${ }^{1,2 *}$, Glagoleva A.Yu. ${ }^{1}$, Shmakov N.A. ${ }^{1}$, Kukoeva T.V. ${ }^{1}$, \\ Khlestkina E.K. ${ }^{1,3}$, Shoeva O.Yu. ${ }^{1}$ \\ ${ }^{1}$ Institute of Cytology and Genetics, SB RAS, Novosibirsk, Russia \\ ${ }^{2}$ Novosibirsk State University, Novosibirsk, Russia \\ ${ }^{3}$ N.I. Vavilov Research Institute of Plant Industry, St. Petersburg, Russia \\ *email:vikhorev@bionet.nsc.ru
}

Dark pigmentation of barley spike (Hordeum vulgare L.) can be caused by two types of phenolic compounds: anthocyanins that belong to flavonoids and provide blue or purple color of grain and black or brown melanins that are result of enzymatic oxidation of phenolic compounds. Different genes control the accumulation of these pigments: the complementary genes Ant 1 and Ant 2 determine synthesis of purple anthocyanins in grain pericarp; while melanins are formed under control of the Blp gene in hulls and pericarp tissues. These colorants can be accumulated in grain envelopes independently or simultaneously, and presumably the same phenolic substrates can be involved. However, the exact mechanisms of anthocyanins and melanin biosynthesis pathways interaction were not investigated previously. Using the marker-assisted selection the hybrid nearisogenic line (NIL) i:BwBlpAnt1Ant2, which simultaneously accumulates anthocyanins and melanin in grain was developed. In addition to parental black-grained i:BwBlp and purple-grained i:BwAnt1Ant2 NILs and initial cultivar Bowman the obtained line is a precise genetic model for comparative transcriptomic analysis. Total RNA from NILs at three stages of spike development (booting, late milk and early dough stages) was extracted and sequenced. In total, 36 sequenced Illumina mRNA libraries were obtained. We have found upregulation of the key flavonoid biosynthesis genes in hybrid line that occurs earlier than in the purple-grained line, at the late milk stage of spike maturation. Besides, the obtained transcriptomic data demonstrated the downregulation of photosynthesis genes in NIL accumulating melanin. Thus, we assume that the presence of the Blp locus increase anthocyanins biosynthesis and suppress chlorophyll biosynthesis in barley grain.

Acknowledgements: The study was supported by the RFBR grant No. 20-316-80016. 


\title{
Transcriptomics of plants in the Chernobyl exclusion zone: a step closer to understand the adaptation to chronic radiation exposure
}

\author{
Volkova P.Yu. ${ }^{1 *}$, Duarte G.T. ${ }^{2}$, Podlutskii M.S. ${ }^{1}$ \\ ${ }^{1}$ Russian Institute of Radiology and Agroecology, Obninsk, Russia \\ ${ }^{2}$ Max Plank Institute of Molecular Plant Physiology, Potsdam, Germany \\ *email:volkova.obninsk@gmail.com
}

The Chernobyl exclusion zone (CEZ) provides unique opportunities for investigation the effects of long-term chronic radiation exposure on plant populations. Plants belonging to different genera can significantly differ in sensitivity to acute and chronic radiation exposure. Field sampling was performed in the CEZ to investigate the transcriptional profiles of herbaceous and tree species growing in the conditions of chronic radiation exposure. The transcriptomic outputs for a radiosensitive tree species Pinus sylvestris and a radioresistant herbaceous species Capsella bursa-pastoris were compared, suggesting an important role of histones, chaperons, and control of transposable elements in plant adaptation to chronic exposure to radionuclides. The seeds of Arabidopsis thaliana plants sampled in the CEZ were subjected to acute high-dose irradiation, and RNA-seq was performed to identify differentially expressed genes triggered by irradiation. The response profiles of plants to acute and chronic radiation exposure were compared, revealing common and distant trends in transcriptomic responses to different modes of exposure.

Acknowledgements: The research has been supported by Russian Science Foundation, project No. 20-74-10004. 


\title{
Evaluation of stress resistance of grape remote hybrids, carrying Vitis rotundifolia Michx. introgressions
}

\author{
Volynkin V.A., Likhovskoi V.V., Vasylyk I.A.*, Lushchay E.A., Gorislavets S.M., \\ Volodin V.A., Risovannaya V.I., Potokina E.K. \\ All-Russian National Research Institute of Viticulture and Winemaking "Magarach” RAS, Yalta, Russia \\ *email: kalimera@inbox.ru
}

In the Vitaceae family, species are distinguished that are resistant to individual or complex pathogens and frost. One such species is Vitis rotundifolia. In the process of research, new scientific knowledge has been obtained about the inheritance of traits of grape resistance to pathogens that cause mildew and oidium diseases and frost from Vitis rotundifolia. The objects of research were the recombinant lines of three populations from the crossing of the maternal form $q$ M. No. 31-77-10 with hybrids of the progeny of Vitis rotundifolia. The frost resistance trait is not due to specific genes, which is typical for other traits, but is determined by the genotype of the plant as a whole. It was found that in breeding for frost resistance, the use of the form $q \mathrm{M}$. No. 31-77-10 has the character of a specific combinational ability to inherit resistance. As a result of laboratory screening in the population +M. No. 31-77-10 x [DRX-M5-734 + DRX-M5753 + DRX-M5-790], more than $40 \%$ of recombinants are characterized by a high degree of resistance to frost $\left(-24{ }^{\circ} \mathrm{C}\right)$, transgressive recombinants $(6 \%)$ with a very high degree of resistance $\left(-27^{\circ} \mathrm{C}\right)$. The maternal genotype $\rightarrow \mathrm{M}$. No. 31-77-10 does not have alleles of resistance of the Runl locus and is more strongly affected by powdery mildew in the field than in the paternal genotypes. The percentage of powdery mildew spread on vegetative organs in recombinant populations on average over the years of research varies within 3.2-17.1, 0.3-17.7 and 0.6-5.2\% respectively. As a result, almost all recombinant hybrids, having received a resistant allele from the paternal genome, are highly resistant to powdery mildew.

Acknowledgements: The work was supported by the Russian Science Foundation (Project No. 20-16-00060). 


\section{Evaluation of the effect of the WOX family genes overexpression on the somatic embryogenesis}

Yakovleva D.V.*, Tvorogova V.E., Lutova L.A.

St. Petersburg State University, St. Petersburg, Russia

*email:dawarus@yandex.ru

Many plant species have an ability to regenerate through somatic embryogenesis (SE) the process of non-zygotic cells transformation into embryogenic cells, which are able to form a new plant going through characteristic stages of embryonic development. SE is widely used in plant biotechnology as a method of plant reproduction in vitro and it has its applications in plant transformation, breeding, artificial seeds production, but the genetic regulation of SE has not yet been clearly understood. The identification of the regulators of this process is important for improving the methods of obtaining somatic embryos.

Previously in our studies, it was found that overexpression of MtWOX9-1 and STENOFOLIA genes from the WUSCHEL-RELATED HOMEOBOX family of transcription factors leads to an increase in the capacity for SE in Medicago truncatula. We hypothesized that other WOX genes of M. truncatula can also have an impact on the SE.

The aim of this study is to search for new WOX genes, which can be involved in SE regulation in $M$. truncatula. We found that several $M$. truncatula genes from the WOX family increase their expression level during SE or in the generative organs. We suppose that the change in the function of these genes could have an effect on the SE capacity. We are planning to obtain modified plants with overexpression of these WOX genes and to measure the ability of such plants to form somatic embryos in vitro. At this moment, several vector constructions for overexpression are obtained and we are going to introduce them into $M$. truncatula plants. If there are interesting cases of WOX genes overexpression manifestations, CRISPR/Cas9 system will be used to inactivate such WOX genes and to explore further their functions during SE.

Acknowledgements: The research was supported by the RFBR (20-016-00124). 


\title{
Order of chromosome arrangement location in late prophase - early prometaphase of mitosis in haploid maize plant obtained with the use of mutation ig
}

\author{
Yudina R.S., Levites E.V.* \\ Institute of Cytology and Genetics, SB RAS, Novosibirsk, Russia \\ *email:levites@bionet.nsc.ru
}

Despite the huge amount of works devoted to the study of mitotic division, there is still a lot of unclear in its mechanisms. For example, insufficient attention has been paid to the processes of cell division in plant forms of different ploidy levels. The literature contains only fragmentary data on haploids in lower plants. This does not allow making any generalizations regarding mitosis in haploids of higher plants. This message presents the results of a cytological study of mitotically dividing cells of haploid maize plants. The message demonstrates the effectiveness of the well-known Chase method, based on the use of genetic markers and the ig mutation (indeterminate gametophyte) for obtaining and detecting haploids. An effective modification of a simple method of acetocarmine staining of cytological preparations is described. An essential result obtained is, in our opinion, the detection of a very brief moment in the state of chromosomes in a dividing cell of a haploid maize plant. This moment is characterized by the fact that the chromatids have already separated and turned into independent chromosomes, but have not yet begun their movement under the action of kinetochore microtubules. It is this feature that made it possible to designate this state as late prophase - early prometaphase of mitosis. An equally important feature of the detected moment is the unusual ordered arrangement of chromosomes, which lie parallel to each other close to each other along their entire length with the centromeres located on one line, which can be considered the equator of the fission spindle. The revealed fact allows us to assume that an essential role in the formation of such an arrangement of chromosomes is played by the bond of chromosomes with the equator of the nuclear membrane and their subsequent connection with the equator of the fission spindle. 


\title{
Arbuscular mycorrhizal fungi of the North Caucasus and the Gorny Altai: biodiversity and role in plant-microbial interactions
}

\author{
Yurkov A.P. ${ }^{1 *}$, Kryukov A.A. ${ }^{1}$, Gorbunova A.O. ${ }^{1,2}$, Mikhaylova Yu.V. ${ }^{3}$, \\ Zhurbenko P.M. ${ }^{3}$, Shishova M.F. ${ }^{2}$, Rodionov A.V., ${ }^{2,3}$ \\ ${ }^{1}$ All-Russian Research Institute for Agricultural Microbiology, St. Petersburg, Russia \\ ${ }^{2}$ Saint-Petersburg State University, St. Petersburg, Russia \\ ${ }^{3}$ Komarov Botanical Institute, Russian Academy of Sciences, St. Petersburg, Russia \\ * email: yurkovandrey@yandex.ru
}

The aim of our study was to estimate the species diversity of arbuscular mycorrhiza (AM) fungi in two well-known biodiversity "hot-spots" in Russia - the North Caucasus (subalpine meadows of Alibek mountain and Malaya Khatipara mountain, wet ruderal meadow of the Kuban River valley near the village Ordzhenikidzevsky, Karachay-Cherkess Republic) and the Gorny Altai (undisturbed alpine meadow, rocky talus and disturbed ecosystem near the shaft of the abandoned Aktash mercury mine at the level of alpine meadows in Lysukha mountain, Altai Republic). Identification was carried out using primers for Illumina MiSeq: ITS5 primer and modified ITS-2RK primer (5-CGTTCAAAGATTCGATGATTCAC-3) for amplification of the ITS1 region and ITS3 and ITS4 primers for amplification of the ITS2 region.

In the North Caucasus the greatest species diversity of AM fungi was shown for the subalpine grassland of the south-eastern slope of Malaya Hatipara (432 $25^{\prime} 48.0^{\prime \prime} \mathrm{N} 41^{\circ} 42^{\prime} 31.0^{\prime \prime} \mathrm{E}, 2400$ $\mathrm{m}$ above sea level): Archaeospora spainiae, Claroideoglomus claroideum, Diversispora versiformis, Entrophospora infrequens, Funneliformis mosseae, Glomus indicum, Paraglomus laccatum, Rhizophagus irregularis (8 species); the Shannon index was 3.11, the Margalef index was 2.52. In the Gorny Altai the greatest biodiversity of AM fungi was shown for the rocky talus at the level of the alpine meadows of the western slope of Lysukha $\left(50^{\circ} 19^{\prime} 44^{\prime \prime N} 87^{\circ} 43^{\prime} 08^{\prime \prime E}, 2466 \mathrm{~m}\right.$ above sea level): Diversispora arenaria, Glomus macrocarpum, Otospora bareae, Rhizophagus intraradices, Septoglomus africanum (5 species); Shannon index was 2.32, the Margalef index was 2.49. It should be noted the species composition of AM fungi in the presented stationary sample areas of the North Caucasus and the Gorny Altai was completely different, but the diversity indices for the ecosystems with the highest biodiversity were similar, and the largest number of identified AM fungi species (8 species) was observed in the subalpine meadow of Malaya Hatipara. On the other hand the identification with ITS1 sequences was more effective (more species of AM fungi were identificated) than with ITS2 sequences, probably because of the fact that in the first case the PCR was more specific due to the use of our modified primer ITS-2RK. However, the identification of AM fungi species should be carried out for both regions, since some AM fungi species (for example, Entrophospora infrequens, Rhizophagus melanus, Glomus indicum) were determined only for the ITS2 region. For the first time from the soils of the North Caucasus and the Gorny Altai, we isolated AM fungi, which will be deposited in the collection of All-Russian Research Institute for Agricultural Microbiology (ARRIAM). The symbiotic efficiency and activity of AM fungi is being studied. It is planned to commercialize AM fungal strains with high efficiency of phosphate transfer to the host plant.

Acknowledgements: This work was supported by RFBR grants (19-29-05275, and partly 20-016-00245). 


\title{
CLE-peptides in Medicago truncatula somatic embryogenesis
}

\author{
Zlydneva N.S.*, Kudriashov A.A., Tvorogova V.E., Lutova L.A. \\ St. Petersburg State University, St. Petersburg, Russia \\ *email: st086125@student.spbu.ru
}

Somatic embryogenesis (SE) is a phenomenon allowing plants to regenerate embryos from somatic cells. For the development of somatic embryos, interactions between various plant growth regulators are extremely important. Small secreted peptide hormones are involved in the intercellular communication and regulate various physiological processes. One of the groups of plant peptide hormones is the CLAVATA3 (CLV3)/EMBRYO SURROUNDING REGION (CLE) family, whose members play an important role in the differentiation of the shoot and root meristems. Several transcription factors from the WOX family were shown to regulate the expression of certain $C L E$ genes, which, in turn, affect the expression of corresponding WOX genes according to the principle of feedback. Most well-known CLE peptides, functioning in shoot and root meristem, repress the expression of WUS and WOX5 genes respectively, but there are also examples of the positive effect of CLE peptides on the expression of WOX genes in lateral meristems and during the development of zygotic embryos. Previously in our research, it was found that the expression level of some CLE genes changes on the background of overexpression of MtWOX9-1 gene, SE stimulator. The aim of our study is to further investigate the connection between CLE genes and MtWOX9-1 and to analyze the role of these CLE peptides in SE. We found that MtCLE18 or MtCLE6 overexpression does not affect SE capacity of calli, whereas MtCLE16 and $M t C L E 08$ overexpression could possibly suppress and stimulate SE respectively. We are going to test the effect of these peptides on MtWOX9-1 using inducible expression. We have also obtained the vector constructions for generating edited plants with MtCLE08 and MtCLE16 loss of function.

Acknowledgments: The research was ssupported by the RFBR (20-016-00124). 


\title{
The studying of hybrid line with spherical grains and reduced height obtained by crossing triticale and synthetic hexaploid wheat
}

\author{
Zorina M.V. ${ }^{1,2 *}$, Adonina I.G. ${ }^{2}$, Mehdiyeva S.P. ${ }^{3}$, Salina E.A. ${ }^{4}$ \\ ${ }^{1}$ Novosibirsk State University, Novosibirsk, Russia \\ ${ }^{2}$ Institute of Cytology and Genetics, SB RAS, Novosibirsk, Russia \\ ${ }^{3}$ Genetic Resources Institute of ANAS, Azerbaijan \\ ${ }^{4}$ Kurchatov Genomic Center of the Institute of Cytology and Genetics, SB RAS, Novosibirsk, Russia \\ * email: mariamnazorina@gmail.com
}

Spherical grains and reduced height was identified in a hybrid line 1102. These features are valuable in agriculture. The line 1102 was obtained in Genetic Resources Institute of ANAS by crossing triticale ABR $(2 n=6 x=42)$ and synthetic hexaploid wheat ADS $(2 n=6 x=42)$. The karyotype of this line was studied using the GISH and FISH methods; it corresponds to the karyotype of hexaploid wheat $(2 n=6 x=42$, BBAADD). Whole rye chromosomes and translocations were not found in the studied line. Spelt 1 - repeat blocks are found at the ends of the long arms of chromosomes 3B. It may indicate a translocation from Ae. speltoides and requires an additional research. Phenotyping and karyotyping of individual plants of line 1102 showed its homogeneity. The analysis of cultivars of common wheat by grain shape and stem length was carried out in order to select samples for crossing with short-stemmed, round-grain line 1102. The grain shape was assessed by the SeedCounter program. Line 1102 was crossed with spring varieties of common wheat, Kinelskaya 40 and Lutescens 85, which are the most contrasting with it in terms of the studied features to obtain a mapping population for determine the genetic basis of reduced height and spherical grains in the studied line. Moleculargenetic analysis of line 1102 was conducted using markers specific to the already known dwarfing genes (Rht-B1, Rht-D1, Rht-8, Rht-9).

Acknowledgments: This work was carried out as a part of the budget project No. 02592021-0012 and was funded by RFBR, project No. 20-016-00122. 


\section{Autor index}

\author{
Abbasov M.A. 181 \\ Abdukarimov Sh. 38 \\ Abekova A.M. 17 \\ Abugalieva A. 79 \\ Abugalieva S. 23, 79 \\ Adonina I.G. 18, 52, 215, 238 \\ Afanasenko O.S. 19, 109, 137, 187 \\ Afonin A.M. 131 \\ Afonnikov D.A. 78, 179, 203 \\ Agaeva E.V. 51 \\ Ageev A.Yu. 20 \\ Ageeva E.V. 21 \\ Akparov Z.I. 181 \\ Alekseev V.Y. 22, 189 \\ Aliyeva A.J. 181 \\ Almerekova S. 79 \\ Amalova A. 23 \\ Amangeldiyeva A.A. 17 \\ Anapiyaev B. 144 \\ Anashkina A.A. 24 \\ Andreeva E.A. 222 \\ Anisimova O.K. 25 \\ Antipin M.I. 195 \\ Antonov A.A. 117 \\ Antonova O.Yu. 77, 176 \\ Aparina V.A. 26, 43, 174 \\ Arbuzova G. 144 \\ Artyushin I.V. 195 \\ Aseeva T.A. 174 \\ Askhadullin Damir F. 27, 28 \\ Askhadullin Danil F. 27, 28 \\ Aubakirova K.P. 88 \\ Azarova T.S. 35 \\ Babina D.D. 106 \\ Babisekova D.I. 17 \\ Babkenov A. 23 \\ Babkenova S. 23 \\ Badaeva E.D. 29, 52 \\ Bagavieva E.Z. 28 \\ Balashova I.T. 30 \\ Baltin S.M. 31, 224 \\ Bankin M. 208 \\ Baranova O.A. 32, 135, 136, 137 \\ Barbitob Y.A. 87 \\ Bastaubayeva Sh.O. 17 \\ Baygutov M.Zh. 188 \\ Bazhenov M.S. 53, 213
}

Bazylova T.A. 17

Bebykina I.V. 52

Bektayev R.T. 100

Bekhtold N.P. 33, 78

Belan I.A. 34, 170

Belenikin M.S. 195

Belimov A.A. 35

Belkov V.A. 75

Belovezhets L.A. 172

Bemova V.D. 36

Ben C. 48

Berezhnaya A.A. 37, 115

Bespalova L.A. 51, 213

Birukhov V.V. 40

Bishop-von Wettberg E. 20

Blokhina N.P. 34

Bobokhujaev Sh.U. 38, 193

Bogdanova O.V. 158

Boldakov D.M. 51

Boldyrev S. 90

Bome N.A. 39, 227

Bondar E.I. 40

Bondarenko N.P. 134

Bondarevich E.B. 57

Boris K.V. 220, 221

Borisenko N.V. 64

Borovaya S.A. 41

Borovskii G.B. 42, 85

Boulygina E.S. 81, 207

Bovet L. 101

Boyko N.I. 26, 43, 174

Bragina M.K. 114, 115, 196

Budhagatapalli N. 94

Bukin Yu.S. 160

Bulavin I.V. 44

Buriev Z. 38

Burkhanova G.F. 22, 45, 161, 189, 201, 230

Bychkov I.A. 46

Börner A. 47

Büchner H. 50, 194

Chalaya N.A. 62, 119

Chamas S. 50, 62, 124, 194

Changalidi A.I. 87

Chaouachi M. 48

Chasov A.V. 164

Chaturvedi D. 198

Chekunova E.M. 49 
Cherepanova E.A. 45, 189

Chernook A.G. 53

Chernova A. 90

Chernyak E.I. 120

Chilimova I.V. 227

Chirva O.V. 91

Chubukova O.V. 228

Chumakov M.I. 153

Chursin A.S. 202

Clapco S. 58

Daghma D.E.S. 50, 194

Danilova M.N. 55, 145

Davoyan E.R. 51, 52

Davoyan R.O. 51, 52

Davydenko O. 206

De Palo D. 101

Demurin Y. 90

Dergilev A.I. 24, 165

Divashuk M.G. 53, 113, 213

Djébali N. 48

Dmitriev A.A. 157

Dobrovolskaya O.B. 96, 165

Dodueva I.E. 72, 190, 216

Dolgikh V. 54

Dolgov S. 70, 151, 213

Dolinny Y.Y. 227

Domrachev D.V. 62, 120, 124

Doroshenko A.S. 55, 145

Doroshkov A.V. 122

Druzhin A.E. 32

Duarte G.T. 232

Dubina E.V. 56, 125

Dubovets N.I. 57, 166

Duca M. 58

Dudnikov M. 59, 113

Duk M. 60

Dushkin V.A. 117

Dvorianinova E.M. 157

Dvornikova K.A. 138

Dyachenko E.A. 156

Efimov V.M. 187

Efimova M.V. 155

Efremov G.I. 61

Efremova I.G. 111

Egorova A.A. 62, 63, 71, 80, 119, 191

Elatskov Yu. 210

Elatskova A. 210

Elkahoui S. 48

Elkonin L.A. 64

Emirsaliev A.O. 152, 223

Enzekrey E.S. 173
Epifanov R. 65

Ermakovich A. 206

Ermolenko O.I. 89

Evtushenko E.V. 66, 76

Fadeev V.V. 153

Fakhranurova L.I. 103

Fedorova O.V. 171

Fedoseeva I.V. 42

Fedotova O.A. 67, 85

Fedotovskaya V. 68

Fedyaev V. 229

Fedyaeva A.V. 42

Feranchuk S.I. 40

Fesenko A.N. 141

Filyushin M.A. 25, 69

Firsov A. 70

Fomin I.N. 71

Gainullin N. 135

Galibina N.A. 91

Gall N.R. 132

Galushko A.S. 132

Gamburg K.Z. 85

Gancheva M.S. 72, 127, 142, 190

Ganenko T.V. 159

Garapov D.S. 73

Garibyan Ts.S. 74

Garkusha S.V. 56

Garnik E.Yu. 75

Gatzkaya S.S. 66, 76

Gavrilenko T. 77

Genaev M.A. 65, 78

Genievskaya Y. 79

Gentzbittel L. 48

Gerashchenkov G.A. 64

Gerasimova S.V. 62, 63, 71, 80, 119, 120, 123,124

Gladysheva-Azgari M.V. 81, 207

Glagoleva A.Yu. 82, 130, 231

Goepfert S. 101

Gorbenko I.V. 83

Gorbunova A.O. 129, 236

Gordon M.L. 131

Gorislavets S.M. 233

Gorshkova T.A. 84

Goryunov D. 90

Goryunova S. 90

Grabelnych O.I. 67, 85

Graskova I.A. 169

Gretsova M. 86

Gribchenko E.S. 131

Grigoreva E.A. 87, 143, 177 
Grigoriev Y.N. 130

Grishko E.O. 66

Gritsenko D.A. 88, 178

Gruzdev I.V. 89, 118

Gubaev R. 90

Guchenko S.S. 97

Gulayeva E.N. 91

Gultyaeva E.I. 32, 78

Gurina A.A. 92

Guro P.V. 35

Gusev Yu.S. 153

Gvaramiya S. 93, 113, 147, 162

Hackauf B. 222

Hansson M. 204

Hertig C. 62, 63, 80, 94, 120, 123

Hiekel S. 62, 63, 80, 94

Ibragimova S. 62, 95, 191

Ignatov A.N. 96

Ilyushko M.V. 97

Ivanov N.V. 101

Ivanova E.A. 98

Ivanova N.N. 44

Ivanova Yu.N. 99

Jacobi A. 94

Jallouli S. 48

Junker A. 94

Kalendar R.N. 100

Kaminski K.P. 101

Kamionskaya A.M. 156

Kanapin A. 60, 86, 208

Kapustyanchik S.Yu. 102

Karataeva T.A. 103

Karepova M.S. 172

Karlov G.I. 53, 113, 213

Karzhaev D.S. 87, 104, 177

Kasianov A.S. 105, 116, 141

Katyshev A.I. 42

Kazakov E.I. 106

Kazakova E.A. 106

Kelbin V.N. 107, 136

Kenzhegulov O.A. 64

Khabibrakhmanova V.R. 182

Khaitovich P. 90

Khakimova L.R. 228

Khandy M.T. 108

Khatefov E.B. 69

Khiutti A.V. 19, 109

Khlestkina E.K. 63, 80, 82, 120, 123, 130, $148,187,210,231$
Khudokormova J.N. 51

Khusainova I.I. 28

Khusnutdinov E. 110

Khutsishvili S.S. 159

Kibalnik O.P. 111

Kilian B. 29

Kingsly J.N.B. 112

Kirichenko K. 144

Kirov I. 59, 93, 113, 118, 147, 162

Kiseleva A.A. 37, 114, 115, 121, 140

Kiseleva M.I. 136

Klementyeva A. 151, 213

Klepikova A.V. 116, 141

Klimenko I.A. 117

Klykov A.G. 41

Klyushin A.G. 108

Kochetov A.V. 62, 80, 95, 115, 120, 191, 196, 203

Kochieva E.Z. 61, 69, 156

Koeppel I. 62, 63, 80

Kolenkov M.A. 89, 118

Kolganova E. 113

Kolokolova N.N. 39

Kolomiets T.M. 136

Koloshina K.A. 71, 119

Kolosovskaya E.V. 80, 120, 123

Kolozhvari A.E. 115, 121

Komakhin R. 93, 113

Kondakova M.A. 42

Konorov E.A. 195

Konstantinov D.K. 122

Konstantinov Yu.M. 75, 83

Konstantinov Z.S. 74

Konusbekov K.T. 17

Korotaeva N.E. 42

Korotkova A.M. 80, 120, 123

Korsukova A.V. 85

Kostina N.E. 124

Kostylev P.I. 125

Kovalenko N. 135

Kovalenko T. 90

Kovaleva O.N. 82

Kovlagina M. 59

Kovtun A.S. 105

Kozlov K.N. 20

Kradetskaya O.O. 227

Krasnoperova E.Y. 126, 224

Krinitsina A.A. 195

Kriukova K.I. 127

Krivenko O. 152

Kroupin P. 213

Krutovsky K.V. 40, 128

Kryukov A.A. 129, 236 
Kudriashov A.A. 237

Kudryakova N.V. 46

Kudryavtsev A.M. 221

Kudryavtseva L.P. 157

Kudryavtseva Y.A. 172

Kukoeva T.V. 130, 204, 231

Kukoleva S.S. 111

Kulaeva O.A. 131

Kuleshova O.N. 152, 223

Kuleshova T.E. 132

Kulikova D.K. 24

Kumar D. 198

Kumlehn J. 50, 62, 63, 80, 94, 120, 123, 124, 133, 185, 194

Kuptsov S.V. 195

Kushnirenko I.Yu. 134

Kusnetsov V.V. 46

Kuvaeva D.D. 199

Kuzmin D.A. 40

Kuzmin O.G. 202

Kuznetsova K.A. 216

Lang G. 101

Laparra H. 101

Lapidus A. 183

Lapochkina I. 135

Laprina Yu.V. 136

Larichev K.T. 196

Lashina N.M. 19, 109, 137, 187

Lebedeva M.A. 138, 192

Lee C.-R. 20

Leksin I.Y. 139, 146, 164, 182

Leonova I.N. 21, 115, 140, 166

Lesnyak S.A. 56

Levites E.V. 235

Levitsky V. 54

Liaudansky A. 206

Likhovskoi V.V. 177, 233

Litvinov D.Y. 53

Logacheva M.D. 86, 141, 195

Losev M.R. 142

Lushchay E.A. 233

Lutova L.A. 31, 72, 126, 127, 138, 142, 190 , 192, 216, 224, 234, 237,

Luzin A.N. 24, 96

Lykhina A.V. 124

Lytkin K.F. 143

Lyubushkina I. 144

Makamov A. 38

Makarenko M.S. 141

Makarova T. 77

Maksimov I.V. 22, 45, 161, 189, 201
Malyukova A.M. 55, 145

Marchenkova L. 135

Markova Y.A. 172

Martea R. 58

Marthe C. 94

Martynova E. 90

Marzouk T. 48

Matsushita Y. 19, 109

Matveeva T.V. 36

Maulenbay A.D. 188

Mazilov S.I. 153

Mazina A.B. 146, 164

Mehdiyeva S.P. 18, 181, 238

Melnikova N.V. 157

Merkulov P. 93, 113, 147, 162

Mikhailova A.S. 148

Mikhaylova E. 110

Mikhaylova Yu.V. 129, 149, 236

Mikov D.S. 51

Milyukova N.A. 173

Minasbekyan L.A. 150

Minibayeva F.V. 139, 146, 164, 182

Mironenko N.V. 19, 109, 137

Miroshnichenko D. 151, 213

Mirzakhmedov M. 50, 194

Mishin A.S. 103

Mitiouchkina T.Y. 70, 103

Mitrofanova I.V. 44, 81, 152, 207, 220, 223

Mitrofanova O.P. 176

Moiseev A.S. 106

Moiseeva E.M. 153

Moldavanov A. 154

Morgounov A.I. 202

Morozov S.V. 120

Morozova E.V. 26, 174

Mukhina Y.V. 34

Murgan O.K. 155

Mutu A. 58

Nezhdanova A.V. 156

Nikitin P.A. 195

Nikolski M. 212

Nosov A.M. 108

Novakovskiy R.O. 157

Novikova A.A. 158

Novokazi F. 137

Nozhkina O.A. 159, 169

Nurminsky V.N. 160

Nuzhdin S.V. 20, 86

Nuzhnaya T.V. 161, 230

Omarov M. 93, 113, 147, 162

Omelchenko D.O. 141, 195 
Omelyanchuk N.A. 163

Onele A.O. 164

Oreshkova N.V. 40

Orlov Y.L. 24, 96, 165

Orlova E.A. 33, 78, 102

Orlovskaya O.A. 166

Oshchepkov D. 54

Osipova S.V. 180, 205

Otto I. 123

Ozherelev P. 118

Ozolina N.V. 160

Pakina E.N. 96

Panfilova M. 110

Panin V.M. 64

Panova G.G. 132

Park M.E. 219

Pavlichenko V.V. 167

Pendinen G. 77

Penin A.A. 105, 116, 141

Peretyagina T. 90

Perfil'ev R.N. 168

Perfileva A.I. 159, 169

Permyakov A.V. 180, 205

Permyakova M.D. 180, 205

Pershina L.A. 34, 170

Petrash N.V. 171

Petrushin I.S. 83, 172

Pirsikov A.S. 173

Piskarev V.V. 26, 43, 174, 218

Podlutskii M.S. 106, 232

Podobed M.Yu. 106

Poliushkevich L.O. 142

Polyakova E.A. 67, 85

Polyakova M. 144

Pomortsev A. 144

Ponomarev S.N. 175

Ponomareva M.L. 175

Porotnikov I.V.176

Port A. 58

Poteshkina A.A. 174

Potokina E.K. 87, 143, 177, 233

Pototskaya I.V. 202

Potsenkovskaia E.A. 224

Poursarebani N. 94

Povkhova L.V. 157

Pozharskiy A.S. 88, 178

Pravdina O.Yu. 216

Predeus A.V. 216

Pronozin A. 179

Protopopova M.V. 167

Pshenichnikova T.A. 180, 200, 205

Pundir S. 198
Pushin A. 70

Pushkova E.N. 157

Rahimov R.G. 181

Rassabina A.E. 182

Rayko M. 183

Rekoslavskaya N.I. 184, 209

Rezaeva B. 185

Rikhvanov E.G. 42

Risovannaya V.I. 233

Rodionov A.V. 236

Rogozina E.V. 62, 119

Romanov D.V. 186

Romanova A.V. 62, 95, 124

Romanova O.I. 141

Romanyuk D.A. 131

Romashova M.V. 97

Rosseeva L.P. 34, 170

Rozanova I.V. 137, 187

Rozhmina T.A. 60, 157, 208

Rozhnova N.A. 64

Rsaliyev A.S. 188

Ruban M.G. 56

Rumyantsev S.D. 189, 230

Rutkovskaya E.A. 190

Saboiev I. 62, 95, 191

Saburov V.O. 106

Sadikova D.S. 138, 192

Sadovsky M. 68

Safronova V.I. 35

Salina E.A. 18, 21, 37, 52, 62, 95, 107, 114, $115,121,140,151,168,191,196,199$, 215,238

Salyaev R.K. 184, 209

Samoilov A.E. 195

Samsonova A. 60, 86, 208

Samsonova M.G. 20, 60, 86, 208

Sanamyan M.F. 38, 193

Sarsenova S.Kh. 64

Satpathy P. 50, 194

Sauchyn D.G. 42

Sazanova A.L. 35

Schafleitner R. 20

Schelkunov M.I. 141

Scherbakov A. 86

Schnurbusch T. 94

Scobeyeva V.A. 195

Sekste E.A. 35

Sergeeva E.M. 196

Shaloiko L. 70

Shamanin V.P. 107, 202

Shaposhnikov A.I. 35 
Sharapova L.S. 197

Sharko F.S. 81, 207

Sharma Shailendra 198

Sharma Shiveta 198

Sharov V.V. 40

Shchennikova A.V. 61, 69, 156

Shcherban A.B. 18, 168, 199

Shchukina L.V. 200

Shein M.Yu. 22, 161, 201

Shepelev S.S. 202

Shishova M.F. 149, 236

Shlyavas A.V. 221

Shmakov N.A. 80, 120, 203, 231

Shoeva O.Y. 63, 80, 82, 130, 204, 230, 231

Shreyder E.R. 134

Shtark O.Y. 131

Shyshlova-Sokolovskaya A.M. 42

Sibikeev S.N. 32

Sierro N. 101

Siksin S.V. 173

Silkova O.G. 99

Simonov A.V. 180, 205

Singh V.K. 198

Siniauskaya M. 206

Sirota S.M. 30

Skolotneva E.S. 78, 99, 107, 136

Slobodova N.V. 81, 207

Slugina M.A. 156, 225

Smirnova O.G. 180, 205

Smykov A.V. 220

Sochalova L.P. 174

Sofronova A.K. 108

Sokolkova A. 208

Sokolova L.M. 30

Sokolova N. 144

Sokolyuk A.V. 57

Sokornova S. 183

Solodyankin P.A. 49

Solovey L.A. 57, 166

Soloviev A.A. 59, 89, 113, 118

Solovyeva A.I. 214

Sorokan A. 45

Spaselnikova A.V. 124

Speranskaya A.S. 195

Stasyuk A.I. 99, 115, 140

Stepanov A.V. 85

Stepanov I.V. 73

Stepanova A.Y. 214

Stolbikov A.S. 184, 209

Strygina K.V. 63, 80, 130, 148, 210

Sukhareva S. 110

Sukhomlinov V.Yu. 26, 43, 174, 211

Sukhorukov G. 212
Surkova S. 86, 208

Sycheva E.A. 57

Syrova D.S. 35

Tarasenko V.I. 75

Tarelkina T.V. 91

Tazutdinova M.R. 28

Tekhanovich G. 210

Tetyannikov N.V. 39

Thieme R. 77

Tikhonovich I.A. 131

Timerbaev V. 151, 213

Timergalina L. 229

Timin O.Y. 214

Timina O.O. 214

Timonova E.M. 215

Ting C.-T. 20

Tkachenko A.A. 87, 216, 217

Tomilin M.A. 124

Tomilova S.V. 108

Toropova E.Yu. 211, 218

Tretyakova I.N. 219

Trifonova A.A. 220, 221

Trubacheeva N.V. 34, 170

Trunov R.I. 218

Tsvetkova N.V. 222

Tsygankova S.V. 81, 207

Tsyupka V.A. 152, 220, 223

Turuspekov Y. 23, 79

Tvorogova V.E. 31, 126, 216, 224, 234, 237

Tyapkina D.Y. 225

Ubogoeva E.V. 163

Udalova O.R. 132

Ukolova I.V. 226

Ulianich P.S. 87, 177, 217

Urbanovich O.Yu. 42

Utebayev M.U. 227

Vainstein A. 70

Vardevanyan P.O. 150

Vasiliev G.V. 203

Vasilova N.Z. 27, 28

Vasylyk I.A. 177, 233

Vershinin A.V. 66, 76

Vershinina Z.R. 228

Veselov D. 229

Veselova S.V. 22, 161, 189, 230

Vikhorev A.V. 63, 80, 120, 231

Vlasova A.A. 75

Voinikov V.K. 144, 167

Volkov V.A. 87, 177

Volkova P.Yu. 106, 232 
Volodin V.A. 233

Volynkin V.A. 177, 233

Voylokov A.V. 222

Vysotskaya L. 229

Weisfeld L.I. 39, 227

Yakovleva D.V. 224, 234

Yanyshevskaya A. 210

Yashenkova Ya.S. 138

Yerzhebayeva R.S. 17

Yudina R.S. 235

Yurina N.P. 197

Yurkov A.P. 129, 236

Yuzikhin O.S. 35

Zabanova N.S. 85

Zakharova E.V. 74
Zakhrabekova S. 204

Zemlyanskaya E.V. 54, 163

Zenkina K.V. 174

Zhdanova I.V. 223

Zhukov V.A. 131

Zhurbenko P.M. 236

Zinchenco A.N. 52

Zlydneva N.S. 224, 237

Zorin E.A. 131

Zorina M.V. 18, 238

Zubanova Yu.S. 51, 52

Zubkovich A.A. 137

Zuev E.V. 28, 43

Zykin P.A. 222

Özkan H. 29 


\section{Contents}

Molecular analysis of sugar beet samples using the RAPD method.

Abekova A.M., Yerzhebayeva R.S., Bazylova T.A., Babisekova D.I.,

Amangeldiyeva A.A., Bastaubayeva Sh.O., Konusbekov K.T.

The studying genetic regulation of the vaviloid type of spike branching in hybrid lines of hexaploid wheat. Adonina I.G., Zorina M.V., Shcherban A.B., Mehdiyeva S.P., Salina E.A.

Horizontal transfer of potato viroid PSTVd by Phytophthora infestans to and from host plants. Afanasenko O.S., Khiutti A.V., Mironenko N.V., Lashina N.M., Matsushita $Y$.

Modeling of flowering time in mungbean with Approximate Bayesian Computation. Ageev A.Yu., Lee C.-R., Ting C.-T., Schafleitner R., Bishop-von Wettberg E., Nuzhdin S.V., Samsonova M.G., Kozlov K.N.

Study of the relationship between the conductive system of the internodes in spring bread wheat with lodging resistance and yield traits. Ageeva E.V., Leonova I.N., Salina E.A.

Lipopeptide producing endophytic bacteria of the genus Bacillus in the regulation of the expression of genes involved in the defense response of wheat against greenbug aphid Schizaphis graminum. Alekseev V.Y., Shein M.Yu., Veselova S.V., Burkhanova G.F., Maksimov I.V.

Association mapping of quantitative trait loci for agronomic traits in spring wheat collection tested under two water regimes in Northern Kazakhstan. Amalova A., Abugalieva S., Babkenov A., Babkenova S., Turuspekov $Y$.

Protein structure and function analysis for plant stress tolerance on BTB/POZ genes. Anashkina A.A., Luzin A.N., Kulikova D.K., Dergilev A.I., Orlov Y.L.

Identification and characterization of the thaumatin-like genes in garlic. Anisimova O.K., Filyushin M.A.

Phenotyping of soft spring wheat varieties to expand the genetic diversity of cultivars resistant to biotic factors. Aparina V.A., Boyko N.I., Morozova E.V., Sukhomlinov V.Yu., Piskarev V.V.

Resistance to common bunt of bread wheat in the Middle Volga region of Russia.

Askhadullin Danil F., Askhadullin Damir F., Vasilova N.Z.

Resistance to powdery mildew of common wheat in the Middle Volga region of Russia. Askhadullin Damir F., Askhadullin Danil F., Vasilova N.Z., Khusainova I.I., Bagavieva E.Z., Tazutdinova M.R., Zuev E.V.

Genetic diversity of Triticum araraticum assessed using cytogenetics. Badaeva E.D., Özkan H., Kilian B. 
The heritability of carrot resistance to fungal diseases of Alternaria and Fusarium genus.

Balashova I.T., Sokolova L.M., Sirota S.M.

Study of the role of the MtWOX9-1 gene in somatic embryogenesis. Baltin S.M.,

Tvorogova V.E., Lutova L.A.

Resistance of spring bread wheat lines developed by ARISER to abiotic stress and rust

pathogens. Baranova O.A., Sibikeev S.N., Druzhin A.E., Gultyaeva E.I.

Genetics of resistance of spring barley to the agent Ustilago nuda.

Bekhtold N.P., Orlova E.A.

Development of varieties of spring bread wheat using DH lines in Western Siberia.

Belan I.A., Rosseeva L.P., Blokhina N.P., Mukhina Y.V., Trubacheeva N.V.,

Pershina L.A.

The relationship between root exudation, accumulation of heavy metals and symbiotrophy

in peas (Pisum sativum L.). Belimov A.A., Shaposhnikov A.I., Syrova D.S., Guro P.V.,

Yuzikhin O.S., Azarova T.S., Sazanova A.L., Sekste E.A., Safronova V.I.

The homologue of the agrobacterial gene of cucumopine synthase is expressed

in naturally transgenic peanuts. Bemova V.D., Matveeva T.V.

Identification and characterization of two novel $V R N-B 3$ alleles in Russian common wheat. Berezhnaya A.A., Kiseleva A.A., Salina E.A.

Molecular analysis of $\mathrm{BC}_{1} \mathrm{~F}_{1}$ and $\mathrm{BC}_{2} \mathrm{~F}_{1}$ cotton hybrids using SSR markers.

Bobokhujaev Sh., Abdukarimov Sh., Sanamyan M., Makamov A., Buriev Z.

Reaction on water stress of the genotypes Hordeum vulgare L. at different stages of plant development. Bome N.A., Kolokolova N.N., Tetyannikov N.V., Weisfeld L.I.

Annotation of Siberian larch genome draft assembly. Bondar E.I., Feranchuk S.I., Birukhov V.V., Kuzmin D.A., Sharov V.V., Oreshkova N.V., Krutovsky K.V.

The influence of the toxic effect of zinc and mineral starvation on the growth and development of buckwheat regenerants in vitro culture. Borovaya S.A., Klykov A.G. .. 41

The overexpression of the Arabidopsis NDB2 gene in tobacco plants affects the expression of genes encoding the alternative mitochondrial electron transport pathways and stress proteins. Borovskii G.B., Korotaeva N.E., Katyshev A.I., Fedoseeva I.V., Fedyaeva A.V., Kondakova M.A., Rikhvanov E.G., Shyshlova-Sokolovskaya A.M., Sauchyn D.G., Urbanovich O.Yu.

Screening collection varieties of VIR for resistance to stress factors (resistance to diseases and lodging) at Novosibirsk region. Boyko N.I., Aparina V.A.,

Sukhomlinov V.Yu., Zuev E.V., Piskarev V.V.

Hyssopus officinalis L. genetic similarity in vitro.

Bulavin I.V., Ivanova N.N., Mitrofanova I.V.

Endophytic bacteria of the Bacillus induce resistance of potato plants to viruses.

Burkhanova G., Sorokan A., Cherepanova E., Maksimov I. 
Effect of melatonin deficiency and disruption of its receptor signaling pathway on photosynthetic parameters and expression of chloroplast genes in plants of Arabidopsis thaliana under photooxidative stress. Bychkov I.A., Kudryakova N.V., Kusnetsov V.V.

Plant genetic resources for improving stress tolerance - examples for cereals. Börner A.

Tomato endophytic bacteria bioactive compounds as potential agents for the postharvest biocontrol of gray mold disease. Chaouachi M., Marzouk T., Jallouli S., Elkahoui S., Gentzbittel L., Djébali N., Ben C.

Role of GATA-family transcription factors in the regulation of chlorophyll biosynthesis in green unicellular algae Chlamydomonas reinhardtii. Chekunova E.M., Solodyankin P.A.

Site-directed mutagenesis of maize elite germplasm through pollination by cas $9 / \mathrm{gRNA}$ transgenic, haploidy-inducing lines. Daghma D.E.S., Mirzakhmedov M., Chamas S., Büchner H., Satpathy P., Kumlehn J.

Creation of common wheat lines with pyramids of genes for resistance to leaf rust. Davoyan E.R., Bespalova L.A., Agaeva E.V., Davoyan R.O., Khudokormova J.N., Zubanova Yu.S., Mikov D.S., Boldakov D.M.

Using synthetic forms of RS5 and RS7 to expand the genetic diversity of common wheat for disease resistance. Davoyan R.O., Bebykina I.V., Davoyan E.R., Zubanova Y.S., Zinchenco A.N., Badaeva E.D., Salina E.A., Adonina I.G.

Effect of allelic forms of GRFs genes on the development of common wheat under different conditions of nitrogen supplementation. Divashuk M.G., Litvinov D.Y., Chernook A.G., Karlov G.I., Bazhenov M.S.

Structural and functional characterization of transcription factor binding sites: from bioinformatics to hormone biosensors. Dolgikh V., Levitsky V., Oshchepkov D., Zemlyanskaya E.

Involvement of the red light receptors phytochrome A and phytochrome B in the regulation of gene expression of the plastid transcription apparatus by cytokinin during de-etiolation of A. thaliana. Doroshenko A.S., Malyukova A.M., Danilova M.N. 55

DNA-technologies in rice breeding for resistance to bio- and abiotic stressors.

Dubina E.V., Ruban M.G., Garkusha S.V., Lesnyak S.A. 56

Informative SSR markers for genotyping and intervarietal differentiation of cultivated oat. Dubovets N.I., Sycheva E.A., Sokolyuk A.V., Bondarevich E.B., Solovey L.A. 57

ISSR and SSR markers in assessing genetic diversity of Orobanche cumana.

Duca M., Port A., Clapco S., Martea R., Mutu A. 58

Identification and variation analysis of long non-coding RNA genes expressed at early stages of seed development in Triticale. Dudnikov M., Kovlagina M., Soloviev A., Kirov I. 
Genomic signatures of flax diversification and improvement. Duk M., Kanapin A.,

Samsonova A., Rozhmina T., Samsonova M. .

Z-ISO: a catching up step towards formation of colored carotenoids in tomatoes.

Efremov G.I., Shchennikova A.V., Kochieva E.Z.

Developing potato varieties with decreased cold-induced sweetening. Egorova A.,

Gerasimova S., Ibragimova S., Romanova A., Saboiev I., Domrachev D., Koeppel I.,

Hertig C., Hiekel S., Chamas S., Kumlehn J., Rogosina E., Chalaya N., Salina E.,

Kochetov A.

Targeted modification of regulatory genes associated with barley grain color formation.

Egorova A., Strygina K., Shoeva O., Hertig C., Gerasimova S., Koeppel I., Hiekel S.,

Vikhorev A., Kumlehn J., Khlestkina E.

Improvement of sorghum seed storage protein digestibility using RNA-interference and genome editing. Elkonin L.A., Gerashchenkov G.A., Panin V.M.,

Kenzhegulov O.A., Sarsenova S.Kh., Rozhnova N.A., Borisenko N.V.

Applying neural network for the segmentation of spike structural elements.

Epifanov R., Genaev M.

Paralogous genes of centromeric histone CENH3 are actively expressed in the rye genome. Evtushenko E.V., Gatzkaya S.S., Grishko E.O., Vershinin A.V.

Non-phosphorylating alternative respiratory pathways are involved in an increase of wheat resistance to heat stress. Fedotova O.A., Polyakova E.A., Grabelnych O.I.

Triplet composition of common mitochondrial and chloroplast genes of plants reveals their differentiation. Fedotovskaya V., Sadovsky M.

Analysis of liguleless1 gene associated with ligule development in Zea mays L.

Filyushin M.A., Khatefov E.B., Kochieva E.Z., Shchennikova A.V.

Agrobacterium-mediated transformation of Chrysanthemum with artemisinin biosynthesis pathway genes. Firsov A., Mitiouchkina T., Shaloiko L., Pushin A., Vainstein A., Dolgov S.

StCDF1 gene editing strategy in potato wild species within de novo domestication concept. Fomin I.N., Egorova A.A., Koloshina K.A., Gerasimova S.V.

CLE genes in tuber development in potato (Solanum tuberosum L.). Gancheva M.S.,

Dodueva I.E., Lutova L.A.

IRAP-analysis of genetic diversity in Chinese plum (Prunus salicina) varieties distributed in southern regions of Siberia. Garapov D.S., Stepanov I.V.

Study of the effect of nutrient medium components on the regenerative abilities rapeseed explants (Brassica napus), Antares variety. Garibyan Ts.S., Konstantinov Z.S.,

Zakharova E.V. 
The dark-induced senescence disruption in Arabidopsis thaliana glutamate dehydrogenase knockout mutant gdhlgdh2. Garnik E.Yu., Vlasova A.A., Belkov V.A., Tarasenko V.I., Konstantinov Yu.M.

Dynamics of the transcription of $C E N H 3$ genes in allopolyploid hybrids of wheat and rye. Gatzkaya S.S., Evtushenko E.V., Vershinin A.V.

Perspectives for introgression of genetic material of Mexican potato species into potato pre-breeding programs. Gavrilenko T., Pendinen G., Antonova O., Makarova T., Thieme R.

Automatic identification of wheat fungi diseases using a convolutional neural network. Genaev M.A., Skolotneva E.S., Gultyaeva E.I., Orlova E.A., Bekhtold N.P., Afonnikov D.A.

Marker-trait associations for barley grain quality traits identified in Karaganda and Kostanay regions using GWAS. Genievskaya Y., Almerekova S., Abugalieva A., Abugalieva S., Turuspekov $Y$.

Cas9/gRNA-mediated modifications of the barley genome for fundamental and applied research. Gerasimova S., Egorova A., Hertig C., Korotkova A., Kolosovskaya E., Strygina K., Shoeva O., Koeppel I., Hiekel S., Vikhorev A., Shmakov N., Kochetov A., Kumlehn J., Khlestkina E.K. 80

De novo genome sequencing, assembly, and analysis of three Russian Prunus persica varieties. Gladysheva-Azgari M.V., Slobodova N.V., Boulygina E.S., Tsygankova S.V., Sharko F.S., Mitrofanova I.V.

Association mapping of the gene controlling melanin synthesis in barley grain using plant genetic resources collections. Glagoleva A.Y., Shoeva O.Y., Kovaleva O.N., Khlestkina E.K.

The mitochondrial plasmids as a new type of mobile genetic elements in higher plants. Gorbenko I.V., Petrushin I.S., Konstantinov Yu.M. 83

Plant cell wall as a target for functional genomics. Gorshkova T.A. 84

Genetic transformation with GOX gene from Penicillium funiculosum as a mean for the increase of potato resistance to the extremal temperatures. Grabelnych O.I., Gamburg K.Z., Stepanov A.V., Korsukova A.V., Fedotova O.A., Polyakova E.A., Zabanova N.S., Borovskii G.B.

Transcriptomic analysis of flowering-time genes in wild and cultivated chickpea. Gretsova M., Surkova S., Kanapin A., Samsonova A., Scherbakov A., Logacheva M., Nuzhdin S., Samsonova M. 86

De novo guar genome assembly and application of "omics" technologies to speed up guar (Cyamopsis tetragonoloba (L.) Taub.) breeding in Russia. Grigoreva E.A., Tkachenko A.A., Ulianich P.S., Karzhaev D.S., Barbitob Y.A., Changalidi A.I., Volkov V.A., Potokina E.K.

SSR profiling of potato cultivars resistant to pathogens. Gritsenko D.A., Aubakirova K.P., Pozharskiy A.S. 
Identification of HMW-GS for development system evaluation bread-making qualities in early breeding generations in spring-sown triticale. Gruzdev I.V., Kolenkov M.A., Ermolenko O.I., Soloviev A.A.

Genetic map construction and QTL mapping of oil-related traits in sunflower from VNIIMK collection. Gubaev R., Boldyrev S., Chernova A., Martynova E., Kovalenko T., Goryunova S., Goryunov D., Peretyagina T., Demurin Y., Khaitovich P. .... 90

Functional characteristics of EST-SSR markers in Pinus sylvestris L. Gulayeva E.N., Tarelkina T.V., Chirva O.V., Galibina N.A.

Genes of NBS-LRR superfamily in Solanum phureja Juz. et Buk. Gurina A.A. 92

T-DNA site identification by Cas9-targeted and whole-genome Nanopore sequencing of Arabidopsis thaliana. Gvaramiya S., Merkulov P., Omarov M., Komakhin R., Kirov I....... 93

Targeted mutagenesis of BRANCHED HEAD homoeoalleles causes alterations of wheat spike and root architecture. Hertig C., Marthe C., Poursarebani N., Budhagatapalli N., Hiekel S., Junker A., Jacobi A., Schnurbusch T., Kumlehn J.

Regeneration capacity of potato cultivars prone to cold sweetening. Ibragimova $S$,

Romanova A., Saboiev I., Salina E., Kochetov A.

Plant virus genome studies using novel databases and bioinformatics tools for text compression and entropy. Ignatov A.N., Orlov Y.L., Luzin A.N., Pakina E.N., Dobrovolskaya O.B. 96

Intra-callus variability of Oryza sativa L. androgenic doubled haploids. Ilyushko M.V., Romashova M.V., Guchenko S.S.

Stress resistance on the example of supramolecular-genetic level of plant development. Ivanova E.A.

Production and characterization of the bread wheat lines with introgression of chromosome 6Agi2 Thynopirum intermedium. Ivanova Yu.N., Stasyuk A.I., Skolotneva E.S., Silkova O.G.

High-throughput application of Palindromic Sequence-Targeted (PST) PCR method for genomic fingerprinting and transposon display. Kalendar R.N., Bektayev R.T.

Alkaloid chemophenetics and transcriptomics of the Nicotiana genus. Kaminski K.P., Bovet L., Laparra H., Lang G., De Palo D., Sierro N., Goepfert S., Ivanov N.V.

Diseases of Miscanthus rhizome: hidden threat for the development of biomass cultivations. Kapustyanchik S.Yu., Orlova E.A.

Poplar trees expressing fungal bioluminescence system. Karataeva T.A., Fakhranurova L.I., Mishin A.S., Mitiouchkina T.Y.

Employing of CRISPR/Cas9 technology to knock out genes associated with flowering in aspen. Karzhaev D.S. 
Novel method for isoform-centered analysis of alternative splicing using a combination of long and short-read sequencing data. Kasianov A.S., Kovtun A.S., Penin A.A.

Transcriptome of the Arabidopsis thaliana Chernobyl ecotype seedlings: simulating of the space radiation action and microgravity. Kazakova E.A., Podlutskii M.S., Moiseev A.S., Kazakov E.I., Saburov V.O., Babina D.D., Podobed M.Yu., Volkova P.Yu.

Advanced panel of molecular markers identifying of stem rust resistance genes $\operatorname{Sr} 2, \operatorname{Sr} 15$, Sr21, Sr22, Sr23, Sr24, Sr25, Sr26, Sr31, Sr35, Sr36, Sr38, Sr39, Sr45, Sr57, Lr6Ai\#2 in Siberian wheat cultivars. Kelbin V.N., Skolotneva E.S., Shamanin V.P., Salina E.A. ... 107

The instrumental cultivation of Phlojodicarpus sibiricus cell culture. Khandy M.T., Sofronova A.K., Tomilova S.V., Klyushin A.G., Nosov A.M.

Tolerance of potato cultivars to potato spindle tuber viroid PSTVd. Khiutti A.V., Mironenko N.V., Lashina N.M., Matsushita Y., Afanasenko O.S.

The knockout of predicted MYB60 gene in Eruca sativa promotes anthocyanin accumulation. Khusnutdinov E., Panfilova M., Sukhareva S., Mikhaylova E.

Stress immunity of CMS lines of Sorghum bicolor (L.) Moench at the basis of different cytoplasmic sterility types. Kibalnik O.P., Efremova I.G., Kukoleva S.S.

Genome editing in wheat: exploration of new challenges for crop improvement. Kingsly J.N.B.

Breakthroughs in plant retrotranscriptome and mobilome characterization enabled by Nanopore sequencing. Kirov I., Merkulov P., Gvaramiya S., Omarov M., Dudnikov M., Kolganova E., Komakhin R., Divashuk M., Karlov G., Soloviev A.

Functional characterization of genes with circadian expression patterns in common wheat. Kiseleva A.A., Bragina M.K., Salina E.A.

An integrated approach to study genetics of Triticum aestivum vegetation period. Kiseleva A.A., Stasyuk A.I., Bragina M.K., Berezhnaya A.A., Kolozhvari A.E., Leonova I.N., Kochetov A.V., Salina E.A.

Gene expression stability at high evolutionary distances. Klepikova A.V., Kasianov A.S., Penin A.A.

Evaluation of genetic diversity in Brassica L. species and cultivars through application of microsatellite markers. Klimenko I.A., Dushkin V.A., Antonov A.A.

Study of varieties of spring triticale for the presence of the wbm gene. Kolenkov M., Ozherelev P., Gruzdev I., Soloviev A., Kirov I.

Optimization of cultural conditions for in vitro regeneration of wild potato species. Koloshina K.A., Egorova A.A., Chalaya N.A., Rogozina E.V., Gerasimova S.V.

Studying the regulation of epicuticular wax biosynthesis in barley using isogenic WINI/winl lines generated by site-directed mutagenesis. Kolosovskaya E.V., Gerasimova S.V., Korotkova A.M., Hertig C., Morozov S.V., Chernyak E.I., Domrachev D.V., Vikhorev A.V., Shmakov N.A., Kochetov A.V., Kumlehn J., Khlestkina E.K. 
The study of the wheat $P p d-D 1$ regulatory region using Cas9 RNA-directed nuclease system. Kolozhvari A.E., Kiseleva A.A., Salina E.A.

Meta-analysis of drought-induced transcriptome changes for Zea mays.

Konstantinov D.K., Doroshkov A.V.

Targeted knockout of the NUD gene in Siberian barley. Korotkova A.M., Kolosovskaya E.V., Gerasimova S.V., Hertig C., Otto I., Kumlehn J., Khlestkina E.K...... 123

Phenotypic characteristics of tobacco plants harboring mutations in nicotine biosynthesis genes from PMT and QPT gene families. Kostina N.E., Lykhina A.V., Domrachev D.V., Spaselnikova A.V., Tomilin M.A., Romanova A.V., Chamas S., Kumlehn J., Gerasimova S.V.

Transfer of rice resistance genes to blast using DNA markers. Kostylev P.I., Dubina E.V. .... 125

WOX family genes in somatic embryogenesis. Krasnoperova E.Y., Tvorogova V.E., Lutova L.A.

Analysis of the activity of the DR5 promoter in tuber-forming plants. Kriukova K.I., Gancheva M.S., Lutova L.A.

Forest genomics: main achievements and future prospects. Krutovsky K.V.

Investigation of SWEET family sugar transporter genes and their role in arbuscular mycorrhiza. Kryukov A.A., Gorbunova A.O., Mikhaylova Yu.V., Yurkov A.P.

Comparative characteristics of barley hybrids by the anthocyanins content in grain.

Kukoeva T.V., Glagoleva A.Y., Shoeva O.Y., Grigoriev Y.N., Strygina K.V.,

Khlestkina E.K.

Comprehensive analysis of Pisum sativum (L.) microRNAs. Kulaeva O.A., Zorin E.A., Romanyuk D.A., Gribchenko E.S., Afonin A.M., Gordon M.L., Shtark O.Y., Tikhonovich I.A., Zhukov V.A.

Gradient of the rhizosphere bioelectric potentials as a source of green energy. Kuleshova T.E., Gall N.R., Galushko A.S., Udalova O.R., Panova G.G.

Site-specific genetic engineering in cereals - principles and applications. Kumlehn J.

Resistance of common spring wheat genotypes to abiotic and biotic stresses in the Southern Urals. Kushnirenko I.Yu., Shreyder E.R., Bondarenko N.P.

Complex resistance of spring bread wheat lines to biotic and abiotic stress. Lapochkina I., Gainullin N., Baranova O., Kovalenko N., Marchenkova L.

Microsatellite markers for regional differentiation of Puccinia graminis f. sp. tritici populations. Laprina Yu.V., Kelbin V.N., Skolotneva E.S., Kolomiets T.M., Kiseleva M.I., Baranova O.A.

Development and validation of molecular markers linked to locus on chromosome $3 \mathrm{H}$ conferring barley resistance to Pyrenophora teres f. teres. Lashina N.M., Rozanova I.V., Novokazi F., Baranova O.A., Mironenko N.V., Zubkovich A.A., Afanasenko O.S. 
Nitrate-activated CLE genes in Medicago truncatula symbiotic nodule development. Lebedeva M.A., Yashenkova Ya.S., Dvornikova K.A., Sadikova D.S., Lutova L.A.

Gene expression in lichen Lobaria pulmonaria in response to UV-B stress. Leksin I.Y., Minibayeva F.V.

Genetic loci for grain protein and gluten content in Russian spring wheat varieties.

Leonova I.N., Kiseleva A.A., Stasyuk A.I., Salina E.A.

Investigation of genetic control of agriculturally important traits in common buckwheat using a combination of genetic mapping and transcriptome analysis. Logacheva M.D., Kasianov A.S., Klepikova A.V., Makarenko M.S., Schelkunov M.I., Omelchenko D.O., Fesenko A.N., Romanova O.I., Penin A.A.

CLE and BAM genes in phloem development in potato (Solanum tuberosum L.).

Losev M.R., Gancheva M.S., Poliushkevich L.O., Lutova L.A.

Development of a genetic map of Vitis vinifera L. backcrossing offspring using high-throughput genotyping. Lytkin K.F., Grigoreva E.A., Potokina E.K.

In vitro biochemical features in calli derived from winter wheat anthers and their possible influences on a secondary embryogenesis. Lyubushkina I., Polyakova M., Pomortsev A., Kirichenko K., Sokolova N., Arbuzova G., Voinikov V., Anapiyaev B.

Phytochrome A and phytochrome B regulate the biosynthesis of chlorophyll during cytokinin-dependent de-etiolation of Arabidopsis thaliana.

Malyukova A.M., Doroshenko A.S., Danilova M.N.

Analysis of stress response genes in moss Dicranum scoparium.

Mazina A.B., Leksin I.Y., Minibayeva F.V.

Detection of active LTR-retrotransposon via eccDNA analysis in Helianthus annuus L., Arabidopsis thaliana and triticale. Merkulov P., Omarov M., Gvaramiya S., Kirov I.

The allelic diversity study of regulatory genes involved in flavonoid biosynthesis in cotton. Mikhailova A.S., Strygina K.V., Khlestkina E.K.

Molecular phylogeny of plant 14-3-3 proteins family. Mikhaylova Yu.V., Shishova M.F.

Epigenetic mechanism of wheat adaptation on a response to the abiotic stress.

Minasbekyan L.A., Vardevanyan P.O.

CRISPR/Cas9 - mediated genome editing of bread wheat to modulate heading time.

Miroshnichenko D., Timerbaev V., Klementyeva A., Salina E., Dolgov S.

Genome-wide approaches in the study of common fig in the Nikita Botanical Gardens.

Mitrofanova I., Krivenko O., Kuleshova O., Emirsaliev A., Tsyupka V.

Analysis and editing the maize gamete interactions and fusion genes. Moiseeva E.M., Gusev Yu.S., Fadeev V.V., Mazilov S.I., Chumakov M.I.

Evolutionary complexification of plant information structure under influence of permanent data flow. Moldavanov A 
The effect of salt stress on the expression of the brassinosteroid biosynthesis genes.

Murgan O.K., Efimova M.V.....

Functional analysis of Solanum lycopersicum L. MADS-box gene SIMADS5.

Nezhdanova A.V., Slugina M.A., Dyachenko E.A., Kamionskaya A.M.,

Kochieva E.Z., Shchennikova A.V.

Genome assemblies of Fusarium oxysporum f. sp. lini strains of different virulence.

Novakovskiy R.O., Dvorianinova E.M., Rozhmina T.A., Kudryavtseva L.P.,

Povkhova L.V., Pushkova E.N., Melnikova N.V., Dmitriev A.A.

Molecular genetic methods for assessing drought resistance of spring barley.

Novikova A.A., Bogdanova O.V.

Manganese-containing bionanocomposites on the basis of natural polysaccharides as novel universal micronutrients for Solanum tuberosum L. Nozhkina O.A., Perfileva A.I., Khutsishvili S.S., Ganenko T.V.

Analysis of the distribution of parameter of membrane lipid phase state. Nurminsky V.N., Bukin Yu.S., Ozolina N.V.

Molecular screening of susceptibility genes Tsn1 and Snnl in the accessions of genus Triticum L. for resistance to the toxins SnToxA and SnTox 1 from the Stagonospora nodorum. Nuzhnaya T.V., Veselova S.V., Burkhanova G.F., Shein M.Yu., Maksimov I.V. 161

Epigenetic profiling of plant LTR retrotransposon copies using Nanopore sequencing. Omarov M., Merkulov P., Gvaramiya S., Kirov I.

Auxin-ethylene transcriptional crosstalk in Arabidopsis thaliana L.

Omelyanchuk N.A., Ubogoeva E.V., Zemlyanskaya E.V.

Class III peroxidase genes in the moss Dicranum scoparium: identification and expression analysis under abiotic stresses. Onele A.O., Mazina A.B., Leksin I.Y., Chasov A.V., Minibayeva F.V.

Statistical estimates of the transcription factor binding sites cluster in Arabidopsis and distant plant species genomes. Orlov Y.L., Dergilev A.I., Dobrovolskaya O.B.

Molecular-cytological analysis of common wheat lines with Triticum dicoccoides genetic material. Orlovskaya O.A., Leonova I.N., Solovey L.A., Dubovets N.I.

Transgenic poplar expressing AtGA20oxl demonstrate fast growing phenotype.

Pavlichenko V.V., Protopopova M.V., Voinikov V.K.

Development of a marker panel for genotyping of soybean cultivars by genes controlling the flowering time and response to the photoperiod. Perfil'ev R.N., Shcherban A.B., Salina E.A.

Generalization of the results on the effect of selenium nanocomposites on the interaction of potatoes with the ring rot disease pathogen. Perfileva A.I., Nozhkina O.A.,

Graskova I.A. 
Alloplasmic lines (Hordeum vulgare)-Triticum aestivum with complete cytonuclear compatibility are the sources of introgression DH lines for wheat breeding.

Pershina L.A., Trubacheeva N.V., Belan I.A., Rosseeva L.P.

The anther culture response in wheat (Triticum aestivum L.) varieties and hybrids.

Petrash N.V., Fedorova O.V.

Genomic features of oil model compounds biodegradation by Rhodococcus qingshengii strain VKM Ac-2784D. Petrushin I.S., Markova Y.A., Karepova M.S.,

Kudryavtseva Y.A., Belovezhets L.A.

Development of molecular markers for the identification of prolamins genes and their correlation with baking qualities of grain. Pirsikov A.S., Enzekrey E.S., Siksin S.V., Milyukova N.A.

Genes of wheat resistant to leaf rust (Puccinia triticina) in Siberia and Far East in 2020 are the basis for determining the breeding strategy for stress resistance. Piskarev V.V., Sochalova L.P., Morozova E.V., Aparina V.A., Boyko N.I., Sukhomlinov V.Yu., Poteshkina A.A., Aseeva T.A., Zenkina K.V.

Progress of breeding strategies in winter rye: from mass selection to genomic selection. Ponomareva M.L., Ponomarev S.N.

Molecular markers of the $S K r$ gene in the evaluation of bread wheat genotypes with different crossability with rye. Porotnikov I.V., Antonova O.Yu., Mitrofanova O.P.

Genomic introgressions of immune Vitis rotundifola Michx into Russian grapevine germplasm revealed by RADseq genotyping. Potokina E.K., Grigoreva E.A., Karzhaev D.S., Ulianich P.S., Volkov V.A., Vasylyk I.A., Volynkin V.A., Likhovskoi V.V.

Evolution of MLO-like proteins in flowering plants. Pozharskiy A.S., Gritsenko D.A.

Identification and structural features analysis of long noncoding RNAs. Pronozin A., Afonnikov D.

Locus $\mathrm{Hl}$, determining leaf pubescence in the genus Triticum L., as a marker of non-homoeological rearrangement $4 \mathrm{~A} / 5 \mathrm{~A} / 7 \mathrm{~B}$, its phenotypic expression and role in adaptation to drought Pshenichnikova T.A., Simonov A.V., Smirnova O.G., Permyakov A.V., Permyakova M.D., Osipova S.V.

Field evaluation of different wheat-alien amphiploids in the conditions of the Absheron Peninsula (Azerbaijan). Rahimov R.G., Akparov Z.I., Abbasov M.A., Aliyeva A.J., Mehdiyeva S.P.

Melanin from the lichen Lobaria pulmonaria: physicochemical properties and biological activity. Rassabina A.E., Khabibrakhmanova V.R., Leksin I.Y., Minibayeva F.V.

Fungal metagenome of Chernevaya Taiga soils: taxonomic composition, differential abundance and factors related to plant gigantism. Rayko M., Sokornova S., Lapidus A..... 183 
The effect of "early"protein of papillomavirus HPV16 E2 made in plant expression system on the base of tomato fruit on tumor formation in mice infected with cancer HeLa cells. Rekoslavskaya N.I., Salyaev R.K., Stolbikov A.S.

Efficient formation of adventitious shoots from immature zygotic embryos of the oilseed crop camelina. Rezaeva B., Kumlehn J.

Repeating elements of the hemp genome (Cannabis sativa L.). Romanov D.V

Development of DNA markers for the selection of spring barley varieties that are resistant to spot blotch. Rozanova I.V., Lashina N.M., Efimov V.M., Afanasenko O.S., Khlestkina E.K.

The pathotype structure of the causative agent Puccinia sp. tritici in Kazakhstan.

Rsaliyev A.S., Baygutov M.Zh., Maulenbay A.D.

The mechanism of the additive action of bacterial compositions Bacillus spp.

in the defense response of common wheat against greenbug aphid Schizaphis graminum.

Rumyantsev S.D., Alekseev V.Y., Veselova S.V., Cherepanova E.A., Burkhanova G.F., Maksimov I.V.

Identification and analysis of CEP genes expression in Solanum tuberosum. Rutkovskaya E.A., Gancheva M.S., Dodueva I.E., Lutova L.A.

Comparative assessment of sugar accumulation in commercial potato cultivars

(Solanum tuberosum L.) for genome editing. Saboiev I., Ibragimova S., Egorova A.,

Salina E., Kochetov A.

CLE genes regulating symbiotic nodule development in Pisum sativum. Sadikova D.S., Lebedeva M.A., Lutova L.A.

Features of crossing and setting of hybrid seeds in hybrid cotton plants with replacement of substitution chromosomes. Sanamyan M.F., Bobokhujaev Sh.U.

Generation of haploidy inducers for Cas endonuclease-mediated mutagenesis in barley. Satpathy P., Mirzakhmedov M., Chamas S., Büchner H., Daghma D.E.S., Kumlehn J. .... 194

Microevolution events in Allioideae (Amaryllidaceae) plastomes. Scobeyeva V.A., Artyushin I.V., Krinitsina A.A., Nikitin P.A., Antipin M.I., Kuptsov S.V., Belenikin M.S., Omelchenko D.O., Logacheva M.D., Konorov E.A., Samoilov A.E., Speranskaya A.S.

The selection of efficient sgRNAs for CRISPR-Cas9 genome editing of potato (Solanum tuberosum L.) aimed to obtain the cultivars with low-amylose starch properties. Sergeeva E.M., Larichev K.T., Bragina M.K., Salina E.A., Kochetov A.V.

Detection of the binding the stress HliA protein Synechocystis sp. with pigments. Sharapova L.S., Yurina N.P.

Genome-wide association study in wheat to identify resistance against Pratylenchus thornei and Heterodera avenae. Sharma Shailendra, Sharma Shiveta, Kumar D., Singh V.K., Pundir S., Chaturvedi D. 
Structural analysis of the candidate gene that controls awn length in common wheat

Triticum aestivum L. Shcherban A.B., Kuvaeva D.D., Salina E.A.

Determination of the size of introgressions from Triticum timopheevii Zhuk. in the recombinant lines of bread wheat cultivar Saratovskaya 29 and their association with protein and gluten content in grain. Shchukina L.V., Pshenichnikova T.A.

The bacterial impact on the transcriptional activity of DCL2 and DCL4 genes in wheat plants infected with Stagonospora nodorum. Shein M., Burkhanova G., Maksimov I. ...... 201

Search of genome-wide associations for breeding of spring wheat varieties with high zinc content. Shepelev S.S., Shamanin V.P., Pototskaya I.V., Chursin A.S., Kuzmin O.G., Morgounov A.I.

Pan-transcriptomic analysis of Solanum tuberosum NLR genes regulating resistance to Phytophthora infestans. Shmakov N.A., Kochetov A.V., Afonnikov D.A., Vasiliev G.V. .... 203

Ant13 encodes the WD40 regulatory factor controlling anthocyanin and proanthocyanidin synthesis in barley (Hordeum vulgare L.). Shoeva O., Kukoeva T., Zakhrabekova S., Hansson $M$.

Influence of an introgression from Triticum timopheevii into chromosome 5A of bread wheat cultivars Saratovskaya 29 and Diamant 2 on agronomical, physiological and biochemical parameters under contrasting irrigation conditions. Simonov A.V., Smirnova O.G., Permyakov A.V., Permyakova M.D., Osipova S.V., Pshenichnikova T.A. 205

The variability of organelle genomes in barley. Siniauskaya M., Ermakovich A., Liaudansky A., Davydenko O.

Analysis of the transcriptomic profile of three peach varieties with different ripening periods. Slobodova N.V., Gladysheva-Azgari M.V., Boulygina E.S., Tsygankova S.V., Sharko F.S., Mitrofanova I.V.

GWAS between flax accessions and agronomically important phenotypic traits. Sokolkova A., Rozhmina T., Kanapin A., Samsonova A., Surkova S., Bankin M., Samsonova $M$.

The study of the cross-interaction of antibodies with antigens of different types of human papillomaviruses (HPV). Stolbikov A.S., Salyaev R.K., Rekoslavskaya N.I. ...... 209

Genes determining dwarfism of watermelon Citrullus lanatus (Thunb.) Matsum. \& Nakai. Strygina K., Yanyshevskaya A., Elatskova A., Elatskov Yu., Tekhanovich G., Khlestkina E.

Spring wheat varieties resistance to the common root rot. Sukhomlinov V.Yu., Toropova E.Yu.

VirHunter: a deep learning-based method for detection of novel viruses in plant sequencing data. Sukhorukov G., Nikolski M. 
Applications of the CRISPR/Cas9 genome editing system for modification of starch content in wheat and triticale. Timerbaev V., Miroshnichenko D., Bazhenov M., Klementyeva A., Bespalova L., Divashuk M.G., Karlov G., Kroupin P., Dolgov S.

Hairy roots characteristics of vegetable pea's morphotype with modified leaf and offspring of the 89/16 sugar line transformant. Timina O.O., Timin O.Y.,

Stepanova A.Y., Solovyeva A.I.

The influence of alien translocations on in vitro androgenesis in lines of spring common wheat. Timonova E.M., Adonina I.G., Salina E.A.

Transcriptomic analysis of radish (Raphanus sativus L.) spontaneous tumors.

Tkachenko A.A., Dodueva I.E., Tvorogova V.E., Predeus A.V., Pravdina O.Yu.,

Kuznetsova K.A., Lutova L.A.

Methylome profiling of guar isogenic lines (Cyamopsis tetragonoloba (L.) Taub.) in different growing conditions using ONT technology. Tkachenko A.A., Ulianich P.S

Spring wheat varieties resistance to biotic stressors. Toropova E.Yu., Trunov R.I.,

Piskarev V.V.

Markers of somatic embryogenesis of Pinaceae species in in vitro culture

(cytohistological, physiological and molecular genetic). Tretyakova I.N., Park M.E.

Genetic diversity of peach from the collection of the Nikita Botanical Gardens revealed by SSR markers. Trifonova A.A., Boris K.V., Tsyupka V.A., Smykov A.V., Mitrofanova I.V.

Genetic diversity of old and local apple cultivars of North Caucasus from VIR collection based on SSR markers. Trifonova A.A., Shlyavas A.V., Boris K.V., Kudryavtsev A.M.

Molecular-genetic analysis of genome incompatibility in wheat-rye hybrids.

Tsvetkova N.V., Zykin P.A., Andreeva E.A., Hackauf B., Voylokov A.V.

Differential gene expression in Lavandula angustifolia Mill. under adaptation ex vitro. Tsyupka V.A., Kuleshova O.N., Emirsaliev A.O., Zhdanova I.V., Mitrofanova I.V.

The search of somatic embryogenesis regulators in Medicago truncatula.

Tvorogova V.E., Baltin S.M., Krasnoperova E.Y., Potsenkovskaia E.A., Yakovleva D.V., Zlydneva N.S., Lutova L.A.

Structural characterization and expression of new gene homologs of GDP-D-mannose-3', 5'-epimerase GME1 in wild and cultivated tomato species. Tyapkina D.Y., Slugina M.A. 225

Subcompartmented oxphosomic model of the mitochondrial oxidative phosphorylation system. Ukolova I.V.

Allelic diversity of gliadin-coding loci of common wheat (Triticum aestivum L.) of Siberian and Kazakh breeding. Utebayev M.U., Bome N.A., Chilimova I.V., Kradetskaya O.O., Dolinny Y.Y., Weisfeld L.I.

Tomato plants carring pph6 gene for phytoremediation. Vershinina Z.R.,

Khakimova L.R., Chubukova O.V. 
Hormonal control of root growth and development in ABA deficient barley mutant. Veselov D., Vysotskaya L., Timergalina L., Fedyaev V.

Different resistance of bread wheat near-isogenic lines carrying various combinations of alleles of the $P p$ and $B a$ genes regulating the biosynthesis of anthocyanin to the pathogenic fungus Stagonospora nodorum. Veselova S.V., Shoeva O.Y., Nuzhnaya T.V., Burkhanova G.F., Rumyantsev S.D.

Study of melanin and anthocyanin biosynthesis regulation in barley grain by transcriptomic analysis of near-isogenic lines with different pigment composition. Vikhorev A.V., Glagoleva A.Yu., Shmakov N.A., Kukoeva T.V., Khlestkina E.K., Shoeva O.Yu.

Transcriptomics of plants in the Chernobyl exclusion zone: a step closer to understand the adaptation to chronic radiation exposure. Volkova P.Yu., Duarte G.T., Podlutskii M.S..... 232

Evaluation of stress resistance of grape remote hybrids, carrying Vitis rotundifolia Michx. Introgressions. Volynkin V.A., Likhovskoi V.V., Vasylyk I.A., Lushchay E.A., Gorislavets S.M., Volodin V.A., Risovannaya V.I., Potokina E.K.

Evaluation of the effect of the WOX family genes overexpression on the somatic embryogenesis. Yakovleva D.V., Tvorogova V.E., Lutova L.A.

Order of chromosome arrangement location in late prophase - early prometaphase of mitosis in haploid maize plant obtained with the use of mutation ig.

Yudina R.S., Levites E.V.

Arbuscular mycorrhizal fungi of the North Caucasus and the Gorny Altai: biodiversity and role in plant-microbial interactions. Yurkov A.P., Kryukov A.A., Gorbunova A.O., Mikhaylova Yu.V., Zhurbenko P.M., Shishova M.F., Rodionov A.V.

CLE-peptides in Medicago truncatula somatic embryogenesis. Zlydneva N.S., Kudriashov A.A., Tvorogova V.E., Lutova L.A.

The studying of hybrid line with spherical grains and reduced height obtained by crossing triticale and synthetic hexaploid wheat. Zorina M.V., Adonina I.G., Mehdiyeva S.P., Salina E.A.

Autor index 239 


\title{
Федеральное государственное бюджетное научное учреждение «Федеральный исследовательский центр Институт цитологии и генетики Сибирского отделения Российской академии наук» (ИЦиГ СО РАН)
}

\author{
Директор - член-корреспондент РАН Алексей Владимирович Кочетов \\ Научный руководитель - академик РАН Николай Александрович Колчанов \\ Ученый секретарь - кандидат биологических наук Галина Владимировна Орлова \\ тел.: +7(383) 363 4985, доп. 1336, email: OrlovaGV@icg.sbras.ru, gorlova@bionet.nsc.ru
}

Институт создан в 1957 г. в числе первых институтов Сибирского отделения АН СССР. В настоящее время ИЦиГ СО РАН - мультидисциплинарный, многопрофильный биологический институт, который по праву считается одним из ведущих научных учреждений биологического профиля в России. В мае 2017 г. закончился второй этап реорганизации Федерального исследовательского центра Институт цитологии и генетики Сибирского отделения Российской академии наук. В настоящее время ФИЦ включает три филиала: Сибирский научно-исследовательский институт растениеводства и селекции (СИБНИИРС), Научно-исследовательский институт клинической и экспериментальной лимфологии (НИИКЭЛ), Научно-исследовательский институт терапии и профилактической медицины (НИИТПМ). Одним из научных подразделений Федерального исследовательского центра стало отделение «Курчатовский геномный центр ИЦиГ СО РАН».

Миссия ИЦиГ СО РАН. Решение приоритетных задач развития научно-технологического комплекса РФ в области генетики и селекции растений, генетики и селекции животных, генетики человека и биотехнологии на основе методов молекулярной генетики, клеточной биологии и биоинформатики. Стратегическая задача. Проведение полных циклов исследований от генерации фундаментальных знаний до прикладных разработок в области генетики и селекции растений, генетики и селекции животных, генетики человека и биотехнологии на основе методов молекулярной генетики, клеточной биологии и биоинформатики, имеющих приоритетное значение для решения задач агропромышленного, биотехнологического, медико-биологического и фармацевтического комплексов России.

Кадровый состав. На 1 мая 2021 г. в ФИЦ ИЦиГ СО РАН 119 научных подразделений, в которых работает 1483 человека, в том числе 503 научных сотрудника, 2 советника РАН, 6 академиков РАН, 4 члена-корреспондента РАН, 96 докторов наук, 307 кандидатов наук.

В ФИЦ ИЦиГ СО РАН обучаются 83 аспиранта и 26 ординаторов.

Публикации. Институт активно публикуется в российских и зарубежных журналах и является в российской биологии одним из признанных лидеров. Общее количество статей в рецензируемых журналах в 2020 году составило 725. В 2016-2020 гг. в системе WoS было публиковано 2068 статей сотрудников ИЦиГ СО РАН, за пятилетний период статьи сотрудников института цитировались в WoS 37160 раз. ФИЦ ИЦиГ СО РАН является лидером среди НИИ и вузов РФ по количеству статей в WoS по направлению Genetics/Heredity.

Журналы. ИЦиГ СО РАН является учредителем следующих журналов: «Вавиловский журнал генетики и селекции», «Письма в Вавиловский журнал генетики и селекции», «Атеросклероз», «Сибирский научно-медицинский журнал» и «Живая наука».

Инфраструктура ИЦиГ СО РАН. УНУ «Центр генетических ресурсов лабораторных животных (ЦГР)» и семь центров коллективного пользования (http://www.bionet.nsc.ru/uslugi/).

Имущественный комплекс. Земельный участок площадью 35 тыс. га, закрепленный на праве постоянного пользования; 85 тыс. м² рабочих площадей, расположенных на территории Советского района г. Новосибирска, Барышевского сельского совета Новосибирской области, в Искитимском и Черепановском районах НСО, в пос. Краснообск Новосибирской области.

Федеральный исследовательский иентр ИЦиГ СО РАН приглашает к сотрудничеству научные и коммерческие организации!

Адрес: 630090, Россия, Новосибирск, проспект Академика Лаврентьева, 10

тел./факс: +7(383) 363 4980/+7(383) 3331278

URL: www.bionet.nsc.ru email: icg-dm@bionet.nsc.ru 


\title{
PLANT GENETICS, GENOMICS, BIOINFORMATICS, AND BIOTECHNOLOGY
}

The $6^{\text {th }}$ International Scientific Conference

Abstracts

Printed without editing

\section{ГЕНЕТИКА, ГЕНОМИКА, БИОИНФОРМАТИКА И БИОТЕХНОЛОГИЯ РАСТЕНИЙ}

\author{
6-я Международная научная конференция
}

Тезисы докладов

Публикуется в авторской редакиии

Выпуск подготовлен информационно-издательским отделом ИЦиГ СО РАН

Подписано к печати 04.06.2021. Формат $70 \times 1081 / 16$. Усл. печ. л. 22.92

Тираж 230 экз. Заказ № 653

Федеральный исследовательский центр «Институт цитологии и генетики

Сибирского отделения Российской академии наук»

630090, Новосибирск, проспект Академика Лаврентьева, 10

Отпечатано в типографии «АЛЕКСПРЕСС»

ИП Малыгин Алексей Михайлович

630090, Новосибирск, просп. Академика Лаврентьева, 6/1, оф. 104, тел. (383) 2174346 

The Conference will present results of the latest research in plant genetics, genomics, bioinformatics, and biotechnology. We plan to discuss promising areas of inquiry (including collaborative studies) in the basic and applied fields of plant genome research.

The conference will include the following sections:

1 Genetics of development and stress tolerance.

2 Evolutionary and functional genomics.

3 Plant biotechnology in the post-genome era.

4 Bioinformatics, plant systems biology and digital phenotyping.

5 Industrial biotechnology.

The working languages of the Conference are English and Russian.

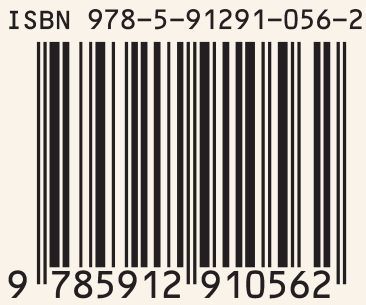

